Universidad de Salamanca

Facultad de Filosofía

Departamento de Filosofía y Lógica y Filosofía de la Ciencia

Doctorado Revisión de la modernidad (2007-2010)

Problemas de una
lectura filosófica de la
poesía colombiana del
siglo XX. Una
aproximación a través
de José Manuel Arango
(1937-2002)

Director: Doctor José Luis

Fuertes Herreros

Autor: Luis Hernando

Vargas Torres 
A la memoria de Julio Moreno Jiménez, mi profesor de quinto de primaria, $y$ a la de mi amigo Jairo Enrique Flechas

Para

José Miguel Vargas B., María Consuelo Reyes A., Alejandro y Ernesto Vargas Reyes y Cristina Martínez A. 
Trabajo para optar al título de doctor en filosofía

Problemas de una lectura filosófica de la poesía colombiana del siglo XX. Una aproximación a través de José Manuel Arango (1937-2002)

Director: Doctor José Luis Fuertes Herreros

Autor: Luis Hernando Vargas Torres 


\section{Contenido}

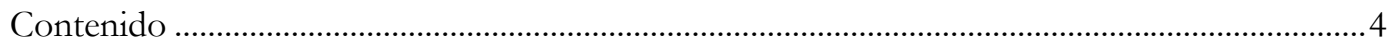

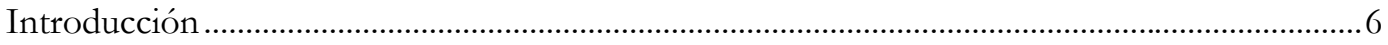

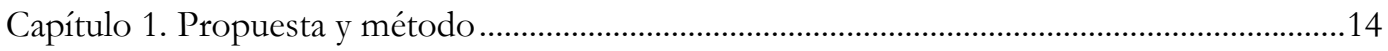

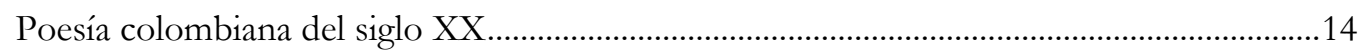

Razones para pensar la poesía colombiana del siglo XX .....................................................21

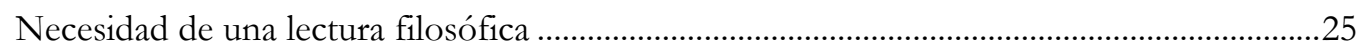

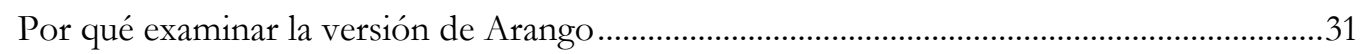

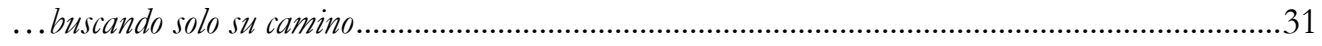

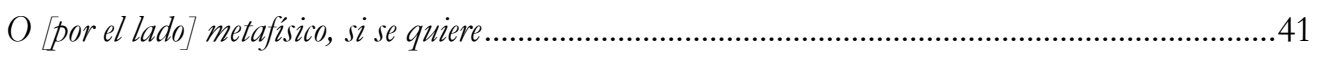

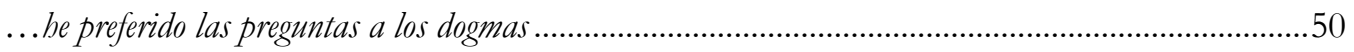

Capítulo 2. Poesía y razón ............................................................................................................55

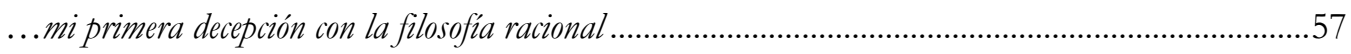

Poesía y límites de la razón ......................................................................................................60

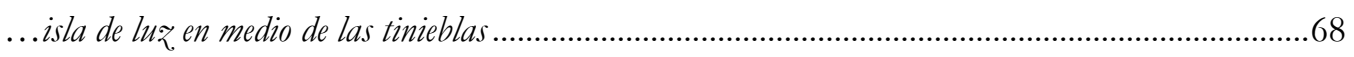

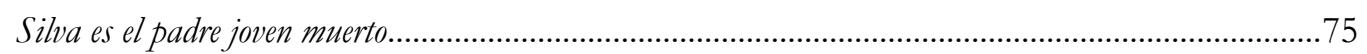

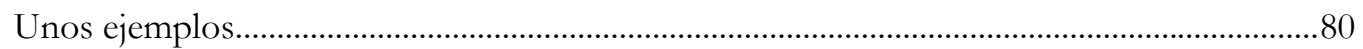

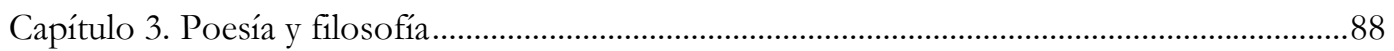

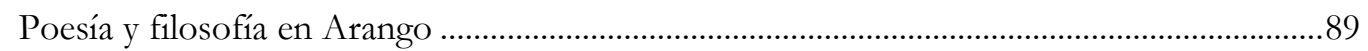

El cambio en la autocomprensión de la filosofía ...........................................................91

Debe ser como una pregunta por lo que somos, ya sabemos que el lenguaje es lo que nos hace..............98

La obra de Arango y el pensamiento de Heidegger.......................................................... 105

La muerte de Dios......................................................................................................... 108

Filosofía y poesía en el siglo XX colombiano..................................................................... 110

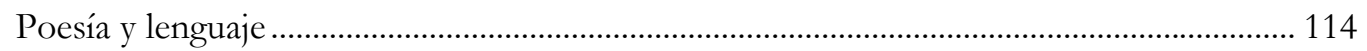

El lenguaje de la poesía............................................................................................... 115

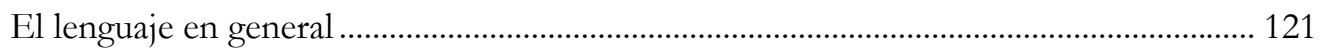

¿Una tradición de la poesía colombiana? ............................................................................. 127

Capítulo 4. Poesía y realidad ….................................................................................................. 130

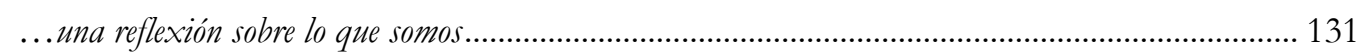

Las raíces de la poesía de Arango ........................................................................................ 132

...uno llega a encontrar una voz [...] por afinidad con otros poetas ............................................ 136

El poema, respuesta a una experiencia personal.............................................................................. 140

...ese vuelo de palabras/ es la poesía......................................................................................... 145

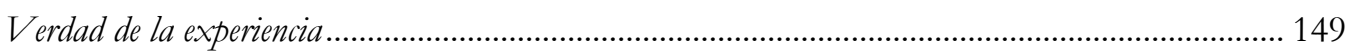

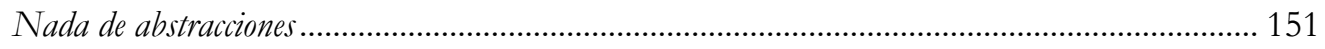

...bachué, señora del agua, enséñame a tocar......................................................................... 152 
De nuevo: ¿una tradición en la poesía colombiana? 154

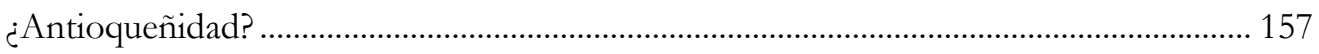

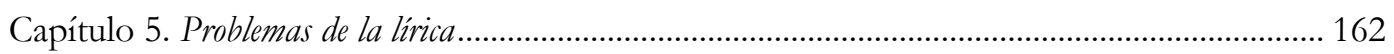

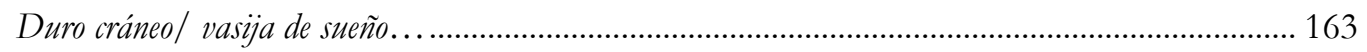

Los problemas de la poesía colombiana del siglo XX ............................................................. 169

...la pregunta por la posibilidad de la poesía ................................................................................... 169

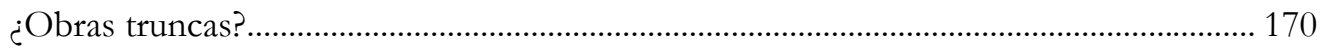

Empobrecimiento de la experiencia y de la dicción poética........................................................ 171

Hubo tiempos en que su lugar parecia claro ........................................................................... 173

...el público es casi siempre una mesa y no un piano ...................................................................... 173

...el poeta es el adolescente.......................................................................................................... 177

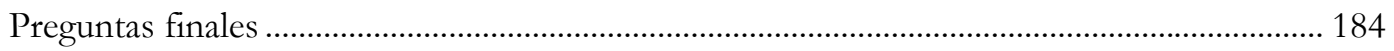

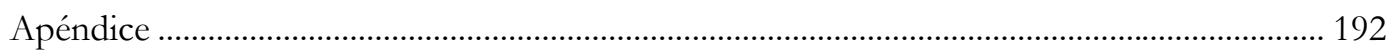

Conversación con José Manuel Arango................................................................................ 192

José Manuel Arango. Conversación con Elkin Restrepo....................................................... 207

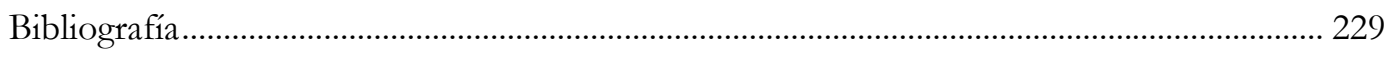

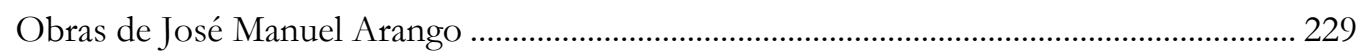

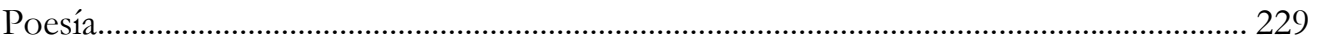

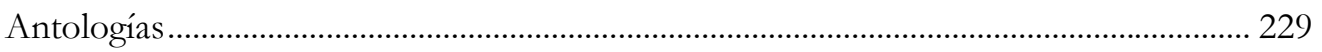

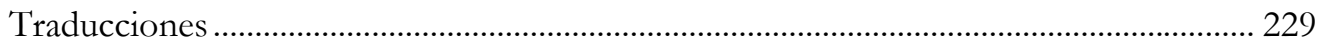

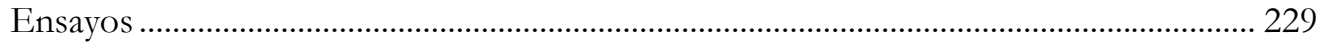

Trabajos sobre José Manuel Arango …………………………………………………...... 230

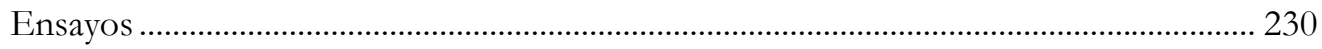

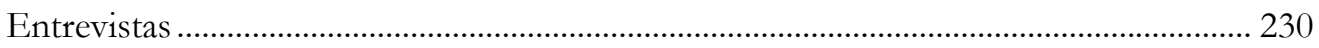

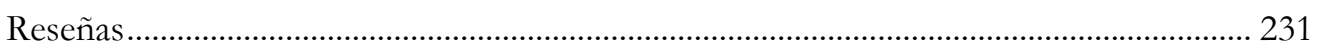

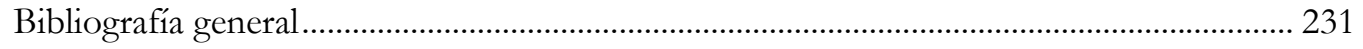

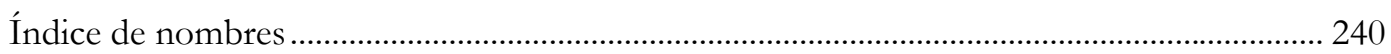




\section{Introducción ${ }^{1}$}

Problemas de una lectura filosófica de la poesía colombiana del siglo XX. Una aproximación a través de José Manuel Arango (1937-2002) es un estudio de la manera de ver un poeta colombiano esta tradición. La tesis aquí sostenida es que la obra de José Manuel Arango permite plantear temas permanentes de la filosofía en general -primado de la experiencia o de la razón, relaciones con la poesía, concepción de realidad; y que, además, lleva a temas específicos de la filosofía del arte o estética -concepción de la poesía, del artista, del receptor de la obra y la obra misma-. Todo esto referido a un periodo y a un espacio muy precisos: siglo XX en Colombia. Por otra parte, sostengo que una consideración filosófica es indispensable para dar cuenta no solo de la poesía de Arango sino de la poesía colombiana del siglo XX.

He llegado a plantear este trabajo a partir de una lectura muy demorada de este autor; y creo que es ella la que me ha llevado muy lentamente a su planteamiento. Por esa razón se funda en trabajos anteriores, de los cuales los más significativos son los siguientes. En 1991 escribí un breve texto llamado "La percepción en la poesía de José Manuel Arango", el cual tenía como tema de reflexión la edición de sus poemas publicada por la Universidad de Antioquia como parte del premio que le otorgó en 1988. Creo que este texto era demasiado prematuro. Pasaron diez años para que intentara de nuevo dar cuenta de la peculiaridad de la poesía del autor. En 2001, con base en poemas reunidos, escribí un breve ensayo titulado "Cosas a un tiempo familiares y ajenas", el cual me permitió conocer al autor y entrevistarlo, hecho que produjo una afirmación del interés que me había llevado a su obra. La muerte del poeta dio a

\footnotetext{
${ }^{1}$ Con base en Manuel Seco, no tildo el adverbio "solo" ni los pronombres "este, esta, ese, esa". Respeto, en la transcripción de citas, sin embargo, la decisión de autores que sí lo hacen, como Arango o David Jiménez.
} 
conocer nuevos trabajos sobre su obra, lo cual sirvió sin duda para que en 2006 escribiera un texto de 130 páginas $^{2}$, del cual no está publicado sino el capítulo central: "Las reflexiones de José Manuel Arango sobre la poesía".

Las particularidades de ese libro inédito casi en totalidad lo hacen merecedor de consideración especial. El primero de los tres capítulos argumenta el método de seguir las orientaciones del poeta para estudiar las peculiaridades de su obra poética; el segundo examina una a una sus poéticas (unos 17 poemas) así como algunas afirmaciones contenidas en entrevistas y ensayos; el tercer capítulo pondera largamente el sentido de esta obra, alrededor de la exploración de un verso, que puede ser considerado una auto síntesis: "Cosas a un tiempo familiares y ajenas".

Este paso en el estudio de la obra de Arango planteó problemas adicionales. Pese a ser un trabajo que tenía ya un método definido: dejar que guiará el poeta la consideración de su propia obra, hizo quizá indispensable que esta consideración fuera acompañada por una mirada filosófica que tuviera en cuenta la historia de la poesía en la cual se levanta esta producción. Y además dejó ver que Arango planteaba una versión sumamente atractiva de la poesía colombiana del siglo XX. Lo dicho creo deja clara la peculiaridad del presente trabajo, a la vez que indica de qué manera un trabajo como José Manuel Arango. Poética y poesía (2006) fue llevando a mirar la poesía del siglo XX en Colombia, con un enfoque muy filosófico.

\footnotetext{
2 De José Manuel Arango. Poética y poesía (2006), solo está publicado el capítulo central "Las reflexiones de José Manuel Arango sobre la poesía” (Boletín cultural y bibliográfico, Vol. XLIII, N 73, 2006 - publicado en 2008-, Banco de la República, Bogotá, 2008, págs.17-52).

Con base en este libro, en el congreso de escritores Jalla (Jornadas andinas de literatura latinoamericana), agosto de 2006, organizado por las Universidad de los Andes y las universidades Nacional y Javeriana y el Instituto Pensar, de Bogotá, leí la ponencia "Aproximación a la poética de José Manuel Arango" - El texto de esta ponencia apareció en las memorias del congreso y fue publicado por la revista Escarabeo (Bogotá, 2006).
} 
Creo que estas aclaraciones permiten precisar las fortalezas y debilidades que puede tener el presente trabajo. Es sin duda una fortaleza el hecho de no partir de teorías sino de la exigencia de lo que quiere ser una escucha dócil de una obra (Para aclarar esto: sé que el filósofo Danilo Cruz Vélez propuso la constitución de una filosofía del lenguaje poético, propuesta de la que no puedo dar cuenta porque apenas la conozco. No parto entonces de propuestas de esta índole). Asimismo habla bien de este trabajo la lentitud de esta lectura. Sin embargo, este texto -No podía ser de otra forma-es solo un intento de consignar un momento de la indagación. Por ello no consideró que los diversos capítulos tengan las mismas condiciones de elaboración.

Consideré largamente el asunto del método a seguir (“Capítulo 1. Propuesta y método"), en la Universidad de Salamanca: dediqué a ello, bajo la dirección del profesor Domingo Hernández, mi trabajo de teoría estética en 2008. Y volví sobre el mismo tema en el año de investigación. El doctor José Luis Molinuevo dirigió mi trabajo "¿Por qué no preguntar a los poetas?, título inspirado por él en una de las sesiones de su curso de docencia. Igualmente el tema de la relación entre poesía y razón (capítulo 2) ha tenido un largo desarrollo. Bajo la tutoría del doctor José Luis Fuertes Herreros, realicé el trabajo "Las reservas de José Manuel Arango ante la filosofía racionalista y el pensar poético de María Zambrano”. Lo que aquí ofrezco son versiones corregidas y aumentadas de esos dos trabajos.

Ya en 2005 había hecho un primer intento de estudiar la relación entre filosofía y poesía en José Manuel Arango. De manera breve indiqué algo sobre ello en mi libro José Manuel Arango. Poética y poesía. No obstante lo anterior, es la primera vez que me detengo por extenso en este tema. Contribuyó a ello una conferencia: en el Primer 
coloquio Internacional de Filosofía y Literatura, organizado por la Universidad Libre, de Bogotá, el 13 de mayo de 2010 leí el texto “Pensamiento y poesía en M. Heidegger”, un intento de diálogo sobre este tema entre Arango y el filósofo alemán. La verdad es que no había caído en cuenta de la envergadura que tiene la indagación de Arango sobre el lenguaje en general, y no solo sobre el lenguaje poético, como es fácilmente esperable en un poeta. Pero no hay nada extraño si se tienen en cuenta la formación, la investigación y la docencia de Arango.

Igualmente es nuevo el capítulo "poesía y realidad” como también lo es el consagrado a los problemas de la poesía, la obra, el poeta y su lector (“Capítulo 5. Problemas de la lírica"). Este último -Y las preguntas que intento dejar abiertas en la sección "Preguntas finales" requiere desarrollos adicionales. Pero es claro que la apertura del horizonte para la comprensión de un autor se va dando lentamente. Quizá, en ocasiones, haya que esperar a que las palabras se abran, y no forzarlas en demasía. Creo que he permitido que diversos problemas planteados por Arango se vayan desplegando y articulando. Pero no está terminada la labor.

Es claro que este autor permite ver de manera muy original la poesía colombiana del siglo XX. Frases suyas como "La poesía enseña a ser... mejor, a no ser", que literalmente me ha sacudido, insinúan claramente esta originalidad. La mayor debilidad que tiene la versión de Arango sobre la poesía colombiana del siglo XX, radica en su fragmentariedad. Son sus observaciones lacónicos fuetazos verbales, que insisten en la memoria y obsesionan la comprensión. Por ello ha sido preciso buscar que esas frases sueltas tuvieran resonancia en obras cuidadosamente escogidas: no se puede aproximar a un autor pensamientos que le son extraños. Aun así creo que este 
trabajo debe de conservar mucho un carácter de esbozo o al menos de mirada brusca y perspectivística en la tradición. Una debilidad adicional estriba en el hecho que si bien de 2002 a la mitad de 2005 dirigí, en la Universidad de Bogotá "Jorge Tadeo Lozano", un seminario llamado "Poesía colombiana del siglo XX", desde entonces no he tenido sobre este tema el contacto siempre fructífero con estudiantes.

Un trabajo como este despierta sospechas. Creo que la manera habitual de considerar la relación entre filosofía y poesía entre nosotros no es en modo alguno la de Arango o Zambrano: se piensa en que son agua y aceite. Por otra parte, quien se consagra a la relación entre filosofía y poesía parece estar en un limbo. El profesor Rubén Sierra Mejía me decía que estos intentos no son del agrado ni de los filósofos ni de los poetas. Pero ya es hora de controvertir lo que llamaba Valéry “opiniones escolares" (“ocurrencias populares", las llama Heidegger).

Repito aquí lo que puse al comienzo de mi libro sobre José Manuel. Como se puede apreciar, he hecho varias aproximaciones a la poesía de Arango. Aún no tengo respuesta a la pregunta de por qué me ha tocado tanto esta obra. Claro que a medida que se despliega la comprensión de ella salta a la luz una obra muy compleja y estructurada. Y de una riqueza tal que hace que se queden cortas las apreciaciones, incluso si son certeras, como las de Darío Jaramillo Agudelo, en una paginita escrita en 1995 con motivo de la publicación de Montañas y aparecida en el Boletín del Banco de la República. Allí hace Jaramillo Agudelo varias aseveraciones sobre Arango: "poeta insular, del mismo modo que lo fueron Aurelio Arturo, Mutis y Mario Rivero para 
sus respectivas generaciones": claro que sí; la suya es "una de las más hermosas colecciones de poemas de la literatura colombiana", es verdad; "Gran poeta", seguro. “Traductor idóneo".

Cualquiera de estas razones pudo haberme conmovido, pero me parece que me llevó a esta obra quizá la preocupación de Arango, que al principio no advertí claramente, por encontrar una poesía acorde con este tiempo. En otras palabras: la notable "conciencia" de poeta que en ella se oculta, su gran lucidez y la hondura de su búsqueda. Creo que muchos de los que han intentado escribir se han encontrado con que la escritura genera un montón de perplejidades: ¿para quién escribo?, ¿con qué lenguaje?, por ejemplo. Y estas preguntas conducen a veces sin saberlo a indagar por lo que es la poesía, incluso desde el punto de vista teórico y filosófico.

En este trabajo publico a manera de apéndice dos entrevistas: la hecha al poeta el 17 de noviembre de 2001, en Copacabana, población cercana a Medellín, y la sostenida con Elkin Restrepo el 17 de noviembre de 2004 en esta última ciudad. La versión publicada de esta contiene las revisiones hechas por Restrepo. En cuanto a la primera, quiero agradecer a Clara Leguizamón, la compañera de José Manuel, la autorización para publicarla.

Al final de un trabajo como este hay que agradecer a muchas personas. Nada hubiera podido hacer sin el apoyo de mi familia. Tengo la suerte de tener con sus miembros incluso la posibilidad envidiable de interlocuciones sobre mis temas, intercambios que me enseñan.

Por otra parte creo que fue una excelente decisión ir a Salamanca. Encontré un grupo de docentes que escucharon y animaron este trabajo. Agradezco la atención 
estimulante y amistosa de los doctores Domingo Hernández, Pablo García y Antonio Notario. En el doctor José Luis Molinuevo Martínez de Bujo encontré a un docente que me hizo advertencias fundamentales y que ha sido siempre aleccionador. Con mi director de tesis, quien ha sido también mi tutor, tengo una deuda impagable: apoyo permanente desde que me vinculé al doctorado, exigencia generosa y una manera de entender la filosofía que es todo un desafío. A él y a Elena Vicente Hernández mis más grandes muestras de gratitud.

Tengo asimismo una deuda con el Boletín del Banco de la República, en particular con Darío Jaramillo Agudelo, quien tras unos 20 años me abrió de nuevo las puertas de esta publicación importante. Juan Gustavo Cobo Borda ha sido un autor del que he aprendido mucho. No solo sobre la poesía colombiana. El encuentro con Cobo Borda siempre permite hacer asociaciones que iluminan. Por otra parte, con generosidad me concedió una entrevista sobre estos temas del siglo XX colombiano y sobre Arango. Agradezco además la escucha tranquilizadora sobre temas del lenguaje de la directora del Instituto Caro y Cuervo, Genoveva Iriarte Esguerra: mi profesora de lingüística en la Universidad Nacional de Colombia me recibió para conversar sobre las indagaciones de Arango en estos temas en los que ella es una especialista.

Finalmente, quiero agradecer al grupo de amigos que están atentos a mis indagaciones, con quienes compartimos desde hace años reflexiones sobre temas de filosofía y de poesía: Carlos Herminio y Eduardo Jaime Puentes, Guillermo Alfonso Sierra Jaime, Miguel Ángel Hernández, Luis Francisco Barrantes. A Catalina Llabrés Malondra y a José Miguel Hernández expreso el reconocimiento a quienes han estado “ahí" buena parte de mi vida. Finalmente, a quien "me metió en la grande", Beatriz 
Helena Múnera, y a María Ángela Gualy quiero decirles que esos ratos pasados paladeando versos no tienen precio.

Bogotá, julio de 2010 


\section{Capítulo 1. Propuesta y método}

Es preciso hacer una lectura filosófica de la poesía colombiana del siglo XX. Y como paso previo, es indispensable plantear problemas filosóficos involucrados en tal lectura. Este trabajo preparatorio es el propósito primordial de Problemas de una lectura filosófica de la poesía colombiana del siglo XX.

Pero ¿qué quiero decir con poesía colombiana del siglo XX? ¿Qué hace necesaria una lectura cuyo solo planteamiento parece tan extraño? ¿Qué camino debe seguir el trabajo propuesto? ¿Cuáles son los problemas a los que se hace referencia? Estos son los interrogantes que guían este primer capítulo.

\section{Poesía colombiana del siglo XX}

Como es fácilmente explicable, tener una versión de primera mano de la poesía de un siglo es prácticamente imposible para quien no se dedica casi que exclusivamente a ello. En mi caso (Aunque el asunto poesía colombiana del siglo veinte está entrelazado con amigos que han mostrado libros y pensado conmigo, pese a que la escritura de ejercicios poéticos haya sido una constante en mi vida), la mejor manera de indicar de una manera breve lo que significa aquí esta expresión, es tomar el hilo conductor de unas cuantas antologías y algunos textos críticos. - Hay que aclarar que me he detenido con intensidad en algunas obras completas de poetas colombianos - Porfirio Barba Jacob (1883-1942), desde tiempos de la secundaria-,

Eduardo Cote Lamus (1928-1964), León de Greiff (1895-1976), Álvaro Mutis (1923), Giovanni Quessep (1939), Aurelio Arturo (1906-1974) y, ante todo, José Manuel Arango-. 
En 1982 cayó en mis manos la Antología crítica de la poesía colombiana (1874-1974), dos tomos, Andrés Holguín, Tercer Mundo, Segunda edición, Bogotá, 1981 (1979). Este trabajo de casi 600 páginas contiene un número de poetas enorme, más de 100, lo cual es sin duda desproporcionado. Sin embargo, fue para mí, por mucho tiempo, una obra de consulta permanente. Como lo ha sido, aunque no con tanta intensidad, la igualmente voluminosa Antología de la poesía colombiana, selección y prólogo de Rogelio Echavarría, Ministerio de Cultura/ El Áncora Editores, Bogotá, 1997, 694 págs. Las casi 700 páginas contienen no solo los mejores poemas "sino los más famosos, los más célebres, casi siempre los más conocidos, en cierta manera los más populares, de cada uno de los más importantes autores de versos en cuatro siglos de expresión colombiana. Son la obra característica, representativa, de nuestros grandes creadores, aunque acogemos también algunas composiciones de poetas menores, que se salvan precisamente por excepcionales, al menos en el contexto de sus propias obras"3. Como es obvio, la segunda antología, que se dedica a cuatro siglos de poesía colombiana no puede servir a mi propósito. En cuanto a la primera, que ha sido de mis afectos, es inmanejable para la reflexión que he venido haciendo por años: un número tan grande de poetas impide la concentración necesaria.

Ahora bien, mi reflexión se alimenta de una antología publicada en 1985: Poesía y poetas colombianos, de Fernando Charry Lara, una obra que cada vez me parece más imprescindible. Dedicada a "acrecentar interés por algunos poetas aparecidos en Colombia hasta poco después de su primera mitad. No se trata, entonces, de una historia de nuestra poesía en ese periodo. Se explica así que no estén todos los que, a

\footnotetext{
${ }^{3}$ Obra citada, págs. 20, 21.
} 
juicio de otro, entrarían en un recuento de nombres al referir esta historia” ${ }^{\text {"4 }} 24$ poetas; medio siglo. Se trata de un trabajo ponderado cuyas únicas tachas podrían estar en la no discusión previa de conceptos como "subjetividad", "interioridad", “expresividad”, “imaginación”, nociones que pueden ser sumamente discutibles, como debe quedar claro en este escrito. Pero de ese defecto quizá no se salva nadie: está en filósofos, poetas y poetas-críticos del periodo. Pero debo ser justo: creo que, como lo mostraré más adelante, Charry, abogado de la Universidad Nacional de Colombia, dado que se ciñe de modo juicioso a las obras, deja que estas quiebren en cierto modo alguno de sus conceptos. Igualmente es en él incómoda la manera de exponer: ¿ No entiendo por qué no habla en primera persona, como por otra parte lo voy a hacer a lo largo de este texto? No hay por qué creer que el yo expresado coincida con la persona que firma o con un individuo: ya sabemos que esa coagulación que es un pronombre integra en una unidad originaria lo que la modernidad llamó sujeto, objeto, mundo y otros hombres. Pero insisto. Para mí, el de Charry es un libro imprescindible. Como considero que lo es una antología que cayó en mis manos hace muy pocos meses. Se llama Antología de la poesía colombiana, de David Jiménez Panesso. Como la de Charry Lara, contiene dos secciones. La parte propiamente antológica (la otra son breves ensayos sobre los poetas y poemas seleccionados) contiene 21 nombres que abarcan el siglo XX: va de José Eusebio Caro y Rafael Pombo ("primeros indicios de la poesía moderna en Colombia", pasa por José Asunción Salustiano Facundo Silva Gómez (1865-1896), y culmina en José Manuel Arango. Hay en esta obra una poda, que quizá es la poda necesaria que hace el tiempo. Queda la pregunta, al considerar el nombre de este libro de si nada de lo

\footnotetext{
${ }^{4}$ Las cursivas son de Charry Lara (Procultura, Bogotá, 1985, pág. 11). En adelante solo señalaré cuando sean míos los resaltados.

5 Antología de la poesía colombiana, Selección y notas bibliográficas: David Jiménez, Grupo Editorial Norma, Colección Cara y Cruz, Bogotá, 2005, pág. 9.
} 
anterior a José Eusebio Caro se salva (E intuyendo a partir de la manera implacable como Jiménez pesa cada palabra y cada decisión, esto es quizá lo que hay que entender). Ahora bien, creo que no solo este trabajo de Jiménez Panesso, poeta él mismo, profesor jubilado de la Universidad Nacional de Colombia, es imprescindible en el campo de la crítica literaria en Colombia. Si bien no podría dar un juicio de conjunto sobre su Historia de la crítica literaria en Colombia. Siglos XIX y XX', ese trabajo me ha aportado reflexiones, particularmente sobre la significación de Silva.

Para esta tesis es muy importante el trabajo de Jiménez Panesso: es uno de los mejores conocedores de la obra de José Manuel Arango. Además de lo ya reseñado, es autor del prólogo y de la selección hecha en la antología publicada con motivo del otorgamiento del Premio Nacional de Poesía?. Por otra parte su artículo "La poesía de José Manuel Arango"8 es un trabajo ejemplar. La tradición en la que se inserta la obra de Arango es ahí escudriñada con extremo cuidado, lo que da muestras del conocimiento profundo de la poesía del siglo XX y universal. Ponderado, sobrio, de estilo atrayente, solo me deja una que otra duda. La primera es el hecho que no aparezcan tematizados o al menos mencionados -en los parentescos que le encuentra a Arango- poetas fundamentales como lo son José Asunción Silva o Antonio Machado: ¿no se interesó por las entrevistas que ya había publicado Arango? Le falta, por otra parte, integrar a la reflexión a los filósofos: para comprender la obra de Arango es imprescindible tener en cuenta a Heidegger, Nietzsche, Unamuno y considerar detenidamente a un pensador como Fernando González. Pero soy

\footnotetext{
${ }^{6}$ Universidad Nacional de Colombia-Instituto Colombiano de Cultura, Bogotá, 1992.

7 José Manuel Arango, Poemas escogidos, "Premio Nacional de Poesía", Universidad de Antioquia, Medellín, 1988.

${ }^{8}$ Jiménez, David, "La poesía de José Manuel Arango", En: José Manuel Arango, La tierra de nadie del sueño. Poemas póstumos, Ediciones DesHora Intergraf, Medellín, 2002. (Este ensayo fue publicado antes en: Boletín cultural y bibliográfico, Banco de la República, Número 47, Volumen XXXV, 1998, págs. 43 a 75). La versión primero indicada contiene adiciones significativas respecto a la del Boletín del Banco de la República. Citaré en adelante la versión de 2002.
} 
injusto: su trabajo es extraordinario y somos nosotros quienes debemos llenar las lagunas de un trabajo que es ya admirable. Son limitaciones inevitables; además de que no se podían escapar estas observaciones a alguien que tiene título de pregrado en Filosofía y letras de la Universidad Pontificia Bolivariana de Medellín y es Magister en Sociología de la Universidad de Essex (Inglaterra). Además de los trabajos mencionados, es preciso indicar, el ensayo "Miguel Antonio Caro: bellas letras y literatura moderna" (En: Miguel Antonio Caro y la cultura de su época -Rubén Sierra, editor, Universidad Nacional de Colombia, Sede Bogotá, 2002, págs. 237 a 260).

Al lado de las obras de Jiménez y Charry, como empeños a los que me vuelvo con insistencia, es preciso mencionar varios trabajos del académico de la lengua, poeta y crítico Juan Gustavo Cobo Borda. En primer lugar, la Historia de la poesía colombiana. Siglo XX. De José Asunción Silva a Raúl Gómez Jattin. Sobre la primera edición, que fue la que llegó primero a mis manos, dice Cobo?: "La primera edición de este libro, publicada por el poeta Elkin Restrepo en 1987, dentro de las ediciones de la Universidad de Antioquia, tuvo un curioso destino: fue puesta como texto de referencia en colegios y universidades y sobre ella realizaron reseñas los alumnos del Seminario Andrés Bello del Instituto Caro y Cuervo. También amigos del Diario de poesía, en Buenos Aires, la hallaron útil para internarse por los caminos de la poesía colombiana en este siglo". Fue muy importante para mí en el momento de su aparición la Antología de la poesía hispanoamericana ${ }^{10}$, libro que presenta, al lado de indiscutibles poetas hispanoamericanos a ocho colombianos: Eduardo Carranza, Fernando Charry Lara, Álvaro Mutis, Jorge Gaitán Durán, Jaime Jaramillo Escobar, Mario Rivero, José Manuel Arango, Giovanni Quessep. Algo que no he podido

9 “Post-facio a la segunda edición”, Villegas Editores, Bogotá, 2003, Segunda edición, pág. 23

${ }^{10}$ Cobo Borda, Juan Gustavo, Fondo de Cultura Económica, México, 1985. 
entender es que este libro, que abarca los años 1910 a 1939, excluya a Aurelio Arturo. Es cierto que nació en 1906, pero el trabajo de Arturo es una obra que gravita en la creación contemporánea. A mí me gusta la selección de Cobo Borda, pero ni Jaime Jaramillo Escobar, ni Mario Rivero, ni Giovanni Quessep, aparecen entre los 21 poetas de Jiménez; Aurelio Arturo es en cambio indiscutible en cualquier antología. Me reservo por ahora el juicio global sobre los trabajos de Cobo -Tiene además una obra voluminosa-, el cual está entre quienes me han ayudado a darle una acepción a la expresión "poesía colombiana del siglo XX", junto con los dos filósofos que mencionaré enseguida.

Me reservo este tipo de juicio, también, en el caso del filósofo Danilo Cruz Vélez. En este caso sobre el libro El misterio del lenguaje ${ }^{11}$. Como en todos los casos anteriores, tengo mucha desconfianza con el uso de los conceptos que ya indiqué. Dice él, al final del capítulo "II. El lenguaje de la poesía”. “¿Cómo logra una creación de la subjetividad autosuficiente y autónoma del poeta penetrar en el ser de las cosas y sacarlas a la luz? Este sería el problema radical de una filosofía del lenguaje poético”. ¿Hasta qué punto cabe hablar acá de subjetividad? ¿Y de autosuficiente? Pero indiscutiblemente un trabajo como el suyo tiene que ser considerado en una lectura filosófica de la poesía colombiana del siglo XX.

Como tiene que ser considerado el trabajo de Rafael Gutiérrez Girardot. En esta tesis no me referiré sino al trabajo "La literatura colombiana del siglo XX", un ensayo que, como el de Charry, abarca los primeros cincuenta años del siglo $\mathrm{XX}^{12}$. Pero no aborda exclusivamente la poesía. Para mí es un texto imprescindible; pero al

\footnotetext{
11 Planeta, Bogotá, 1995, pág. 59.

12 Gutiérrez Girardot, Rafael, "La literatura colombiana en el siglo XX", en: Manual de historia de Colombia, Colcultura, Bogotá, 1980, págs. 445 a 536.
} 
cual tengo una profunda antipatía. Valioso para pensar la noción de secularización, que recorre el trabajo: me ha mostrado una veta de trabajo fundamental para comprender nuestra sociedad de hoy. Valioso -Aunque me preguntaría hasta qué punto y si debe entrar necesariamente tal conocimiento en la exposición- el principio metodológico de que "el estudio de un autor de cualquier nación latinoamericana presupone un detallado conocimiento de su horizonte social y cultural"13. Pero me inquietan varios aspectos de este trabajo. En primer lugar: la arrogancia del autor, presente desde la primera página, y esa actitud de desprecio que lo lleva llenar de alias antipáticos a los autores que no son de su agrado. Esto es algo importante en lo que tiene que ver con el uso de la razón: en ello se expresa el respeto, base de cualquier discusión, la cual es hoy inevitable. Es fácil por este camino llegar a vociferar en lugar de pensar.

Y me preocupa ante todo que en un trabajo con ese nombre no aparezca tematizado el nombre de Silva. Lo roza apenas un par de veces. Claro. La primera frase del texto dice: "La literatura colombiana del siglo XX se inicia bajo la sombra de Valencia"". Y en la pág.453: "El signo bajo el cual se inició la literatura colombiana en el siglo XX fue el de la simulación. En la viñeta que dibujó Valencia y que veneraron sus admiradores aparece el Maestro con rasgos realmente inverosímiles: los de Goethe y Nietzsche, con los rasgos que inventó la leyenda provinciana de Guillermo Valencia, y que nada tienen que ver con las figuras históricas. Simuló ser como el Weimar, pero no llegó a ser siquiera una sombra difuminada del Olímpico. Su influencia, sin embargo, fue considerable, y su culto parece no tener fin". Este es

13 Ibídem. Nota de pie de página 38, pág. 485.

${ }^{14}$ Ibídem, pág. 447. 
un texto de 1980. Pero ya en 1975, Charry decía en "Divagación sobre Silva"15: "Silva es hoy un poeta más 'contemporáneo' nuestro que Valencia”. Ahora bien, la única justificación a la grave ausencia de Silva podría estar en la siguiente frase de Cruz Vélez referente a Aurelio Arturo:

Aunque él tuvo poco que ver con Mallarmé, lo más característico de su obra poética es que ella, de acuerdo con la exigencia del maestro francés, regresa al lenguaje como su ámbito esencial, superando así una larga etapa de la poesía colombiana, la que se inicia después de Silva, la cual, olvidada del poeta del "Nocturno" III, había estado rondando el peligro de ser ahogada por el sentimentalismo y la sensiblería, por el filosofismo, por la erudición histórica, mitológica, literaria y musical, por los afanes pedagógicos y patrioteros y por el moralismo y el inmoralismo ${ }^{16}$.

La única justificación podría estar en la perspectiva adoptada: algo así como la literatura en el siglo XX vista desde la recepción de las obras. Lo cierto es que creo que presenta mutilado el desarrollo.

\section{Razones para pensar la poesía colombiana del siglo XX}

Que es necesario reflexionar acerca de la poesía colombiana del siglo XX lo dicen las obras de grandes poetas, llámense José Asunción Silva, Aurelio Arturo, Álvaro Mutis, Jorge Gaitán Durán (1924-1962), José Manuel Arango: en ellas diversos problemas que comporta la creación poética y su recepción aparecen tematizados de una u otra manera. Lo dicen también otras obras como las de Rafael Maya (1897-1980) o Andrés Holguín (1918-1989). Claro que esta reflexión aparece en otros poetas, pero mencionamos estos autores en especial porque en ellos -Como lo

\footnotetext{
${ }^{15}$ Lector de poesía, Colección Autores Nacionales, Instituto Colombiano de Cultura, Bogotá, 1975. La cita presente está tomada de la página 429 de Charry Lara, Fernando, José Asunción Silva. Vida y creación, Bogotá, Nueva Biblioteca Colombiana de Cultura, Procultura, Presidencia de la República, 1985, 528 págs.

16 Obra citada, pág. 65.
} 
mostraremos en lo que sigue- la meditación cobra una intensidad y quizá una hondura especial. Natural en un tiempo en que la poesía se ha vuelto problema.

Que es necesario repensar el siglo XX en poesía lo dicen también los errores de la crítica y sus limitaciones. Ya he señalado algo. Y agregaré más. Baste, ahora, como ejemplo, la afirmación de Juan Gustavo Cobo sobre Silva, el fundador de la poesía colombiana del Siglo XX, aseveración escrita en $1997^{17}$ y retomada en 2003, en su Historia de la poesía colombiana. Siglo XX. De José Asunción Silva a Raúl Gómez Jattin:

...es ya Silva un santo al revés. No hay más remedio que repasar todo el asunto, para llegar al fin a sus propias palabras. Pero el nivel en que se desenvuelve es por decir lo menos lamentable.

En este texto Cobo recuerda al poeta y crítico Charry Lara (Pág. 14):

\begin{abstract}
"Seguimos debatiéndonos aún, decía Charry Lara en 1965, con respecto a problemas comunes a vida y poesía [de Silva], dentro de la misma indagación sin salida". Si así fuere nuestro anacronismo sería atroz lo cual es básicamente lo mismo que insinuó también en 1965, Jaime Jaramillo Escobar al preguntarnos: “¿Qué valores tiene Silva para las nuevas generaciones?” Pero estas son preguntas incómodas de poetas y nadie las afronta en serio.
\end{abstract}

La reflexión es propuesta por los poetas mismos y por las limitaciones de la crítica. Pero está también la necesidad de someter periódicamente a revisión los cánones interpretativos: tenemos derecho a examinar las afirmaciones que nos entregan. De otro modo, como se lo dijo Álvaro Mutis a García Márquez en una entrevista del año de 1952, no dejaríamos de ser generaciones de bobitos. Y se presenta así mismo el alejamiento de vastos públicos de esta disciplina, suceso señalado por el mismo Silva, quien ya mostraba la dificultad para leer una poesía sin piso social compartido. Esto es más lamentable aún, como me lo ha mostrado la

17 Silva, Arciniegas, Mutis y García Márquez, Biblioteca familiar, Presidencia de la República, Bogotá, 1997, pág. 10. 
tarea de docencia, en lo que concierne al desconocimiento abismal que hay hoy entre la juventud, el cual creo que es más hondo que en otras épocas. Poesía convertida en poesía para poetas, y sin embargo tan atenta a la época. Atención a la época: Si las razones anteriores tienen que ver con la situación interna de la poesía y de la crítica, este argumento tiene que ver con la labor de poetas atentos al transcurrir de un país agitado por la violencia. Claro está que puede argumentarse que la poesía no tiene una función social de importancia. Pero aunque no creamos como Heidegger que la poesía es la instauración del ser mediante la palabra, no deberíamos apresurarnos a negarle alguna importancia. Recordemos las palabras ponderadas de Eliot en la "Conclusión.31 de marzo de 1933" de su Función de la crítica, función de la poesía: "Considero sensato ponerse en guardia contra toda concepción que espere demasiado de la poesía, lo mismo que protestar contra aquellas que esperan demasiado poco"18.

En cualquier caso es mejor echar una mirada a lo que muestra un examen así sea rápido de la labor de los grandes poetas colombianos. Silva", "uno de los poetas más colombianos que puedan pensarse", frase de Charry; capaz de "un admirable ensayo de reflexión crítica sobre la cultura moderna", como ha dicho David Jiménez; Arturo, autor de una poesía arraigada en un tiempo y un lugar definidos, el sur de su infancia; Mutis cuya desesperanza y cuya poesía de tierra caliente muestran al menos parte de nuestra condición; Gaitán Durán, cofundador de una publicación de la que ha dicho

\footnotetext{
${ }^{18}$ Seix Barral, SA, Barcelona, 1955, 1968 (1933), pág. 152.

19 Silva es una figura intelectual de primer orden. Para David Jiménez es "la más libre las figuras de la literatura colombiana, la más flexible y oscilante". Me pasma el siguiente fragmento de una carta de Silva de septiembre de 1895, citado por Cobo Borda en el texto citado en Silva, Arciniegas, Mutis y García Márquez, págs. 62, 63: "Para hacer obra literaria perfecta es necesario que el organismo tenga la sensación normal y fisiológica de la vida; las neurosis no engendran sino hijos enclenques, y sin un estudio de las leyes mismas de la vida, estudio de los secretos del arte, gimnasia incesante de la inteligencia, esfuerzo por comprender más, por deshacer preconcebidos, por analizar lo más hondo, la obra literaria no tendrá los cimientos necesarios para resistir el tiempo".
} 
Gutiérrez Girardot ${ }^{20}$ : “La fundación de la revista Mito en 1955 significó un salto en la historia cultural de Colombia" ; preocupación en Arango por la relación con las cosas y con los hombres, con un desconcertante reconocimiento de que una raíz de su poesía es "la reflexión sobre lo que somos". Es preciso pensar la poesía colombiana, entonces, porque esta reflexión está propuesta por la poesía misma, por la crítica y porque puede darnos luces para enfrentar retos de hoy. Y problemas quizá atávicos ${ }^{21}$.

${ }^{20}$ Obra citada, pág. 535.

21 Observemos esta cita puesta por David Jiménez en un balance de la poesía de los ochentas ("Poesía colombiana: 1980-1989”, Magazín dominical, El espectador, № 348, diciembre 24 de 1989, pág. 9):

"Nadie mira a nadie de frente, de norte a sur la desconfianza, el recelo entre sonrisas y cuidadas cortesías.

Turbios el aire y el miedo

en todos los zaguanes y ascensores, en la camas.

Una lluvia floja cae

como diluvio: ciudad del mundo

que no conocerá la pazy tampoco la alegría.

(María Mercedes Carranza, “Bogotá. 1982”)

Cada noche, en la calle de erizados

vecindarios, escucho las bocas

que cantan el danzón de las pistolas,

una bala que inaugura un surtidor de rosas rojas.

La noche, ladrona de niños, muerde un país salvaje

y yo aventuro mi voz

por esta tierra de dioses y de adioses.

(Juan Manuel Roca, “Cantata del país salvaje”)

Esta primera hora de la mañana es buena para ver la ciudad

salgo a primera hora y echo a callejear los ojos

las plazas todavía no están atestadas

todavía no es la vida a codazos

las trampas aún no se han armado

la muerte aún no se deja ver por las calles

la muerte descansa a esta hora

anoche tuvo mucho trabajo

matar debe ser fatigoso.

\section{(José Manuel Arango, “Esta primera hora de la mañana”)}

“Son tres momentos diferentes o son tres momentos de un mismo poema, mañana, noche, lluvia, calle, ciudad, país salvaje, en todos el miedo, la muerte que se insinúa, o estalla, o ha dejado ya su huella en el asfalto? Imágenes que pertenecen por igual a ese "país secreto", por cuyas fronteras cruzan los sueños de contrabando todas las noches, según Juan Manuel Roca.

"Pese a su aislamiento con respecto a un supuesto público masivo que consume únicamente cuento televisado, la poesía conserva su significación y su fuerza espiritual de resistencia, incluso contra aquellos que intentan trivializarla desde dentro y disminuir el valor de su trágica confrontación 


\section{Necesidad de una lectura filosófica}

Ahora bien: podemos estar de acuerdo en la necesidad de repensar la poesía colombiana del siglo veinte, pero ¿cómo? La propuesta aquí contenida es la de un enfoque filosófico. Y además una indagación de las relaciones concretas entre la filosofía y la poesía: quizá la filosofía no solo es parte del clima intelectual en el que se ha desarrollado la poesía colombiana del siglo $\mathrm{XX}^{22}$; probablemente está vinculada más internamente de lo que puede suponer la impresión primera. Sea de ello lo que fuere, con toda legitimidad puede la filosofía acompañar la reflexión propuesta por poetas, críticos y realidad ${ }^{23}$.

Pero es necesario repensar la poesía colombiana del siglo XX tomando las suficientes precauciones en el acercamiento a ella misma. Esta es la lección de la fenomenología, llámese trascendental o hermenéutica, y quizá de la filosofía de todas las épocas. Basta solo recordar, a modo de ejemplo, el cuidado que pone Platón en la definición del camino a seguir para encontrar la definición de justicia (areté) en Politeia: un primer libro que sirve de preparación preliminar para, al comienzo del segundo, plantear con rigor el problema y decidir el ya famoso camino a seguir: leer las letras grandes para luego leer las pequeñas, ir del estado al individuo. ¿Cómo hacer, entonces, que hablen las cosas mismas en este terreno? Lo indicado es, como paso

con la vida enajenada. Esta confrontación ha asumido un carácter más bien silencioso. Parecería que mientras más violenta se vuelve la situación del país, más definitiva es la respuesta de la poesía como su polo opuesto. Se diría que la función del poema consiste más en infiltrar un poco de silencio en la barahúnda de la época que en agregar un eco más a la confusión de voces y de gritos que nos ensordece".

22 En un texto que no he trabajado recientemente con el detenimiento debido, advierte Gutiérrez Girardot, en relación al estudio del modernismo, contra la limitación de "quien considera a la literatura como una cadena de cambios estéticos o simplemente formales y sin relación alguna con los problemas que ocuparon a la filosofía del siglo pasado" (Modernismo. Supuestos históricos y culturales, Colección Tierra Firme, Fondo de Cultura Económica, 2004 -1983-, nota de pie de página 58, pág. 84).

${ }^{23}$ Hay una afirmación de Pedro Henríquez Ureña (Citado por Cobo Borda en su Historia de la poesía colombiana, pág. 77) que me inquieta: "Observando por conjuntos, quién no distingue entre la facundia, y la difícil facilidad, la elegancia venezolana a ratos superficial, y el lirismo metafísico, la orientación trascendental de Colombia". 
previo a una relectura de la poesía colombiana del siglo $\mathrm{XX}$, plantear problemas metodológicos y teóricos involucrados en esta empresa. Esta vía permitirá evitar el error de las presuposiciones no ventiladas, yerro frecuente en los estudios de esta poesía. ¿Cuál es el camino seguido en este trabajo? Acudir a las reflexiones de los poetas, y para que la filosofía pueda dar cuenta de la poesía colombiana del siglo XX, indagar donde esté preparado desde dentro de la poesía misma el encuentro con la filosofía. "Allí estará el acceso adecuado".

Creo que hay que partir de un poeta; en esto me parece irreprochable el punto de partida de "Hölderlin y la esencia de la poesía" o el de "El poema", de Heidegger. Sentido común: ¿Quien sabe de su oficio más que el poeta mismo? ${ }^{24}$ Podría ser, entonces, cualquiera de los grandes poetas colombianos, comenzando por José Asunción Silva, de quien ya hemos avanzado algo, el fundador de la poesía colombiana del siglo XX; y agreguemos, como lo señala David Jiménez, que no solo hace en su novela De sobremesa "una fina evaluación de la literatura colombiana e hispanoamericana" sino que además es un autor moderno que "incorpora la crítica dentro del propio proceso creativo". Esto último puede afirmarse de todos los grandes poetas del periodo. El poeta escogido podría ser también Mutis. O Arturo. O Gaitán Durán. O Rafael Maya. O incluso Andrés Holguín, aunque la crítica no lo ubica como gran poeta. ¿Por qué estos poetas? En todos ellos también es muy honda la reflexión sobre el destino de la poesía. Sobre Mutis advierte Charry Lara ${ }^{25}$ (Creo que la precisión en la formulación del problema excusa la extensión de la nota):

Sería de esperar, debe decirse, que las ediciones de la Summa de Maqroll el Gaviero (1973 y 1982), que recogieron la poesía publicada por Álvaro Mutis a lo largo de 25

\footnotetext{
24 Sin embargo, no sobra la cautela que aconsejan algunas expresiones de María Zambrano y el texto de Hans Blumenberg "Situación lingüística y poética inmanente", En: Las realidades que vivimos, Paidós, Barcelona, 1999, págs. 143 a 158.

${ }^{25}$ Fernando Charry Lara, Poesía y poetas colombianos, Procultura, Bogotá, 1985, págs. 128, 129.
} 
años, así como los posteriores poemas suyos contenidos en Caravansary de 1981 y Los emisarios de 1984, permitan no sólo el conocimiento de una obra admirable por muchos aspectos sino también la observación en ella, por el lector atento, de una modernidad que desde un comienzo la emparentó con algunas creaciones poéticas, entre las más valiosas de nuestra época, en las que la interrogación sobre su propio destino constituye la razón misma de su existencia.

A pesar, o tal vez a causa del impulso de su imaginación, la poesía de Mutis no ha dejado de preguntarse, en efecto, cómo debe ser escrita, para quiénes y con qué vocablos, formas e imágenes. Recelosa de sus dones, ha preferido ir en busca de la perdida virtud original del lenguaje. Sus largos silencios dan testimonio, no de mudez, sino de las exigencias que formula el poema y de las vacilaciones acerca de su eficacia posible. Otros poetas, sabemos, suelen estar complacidos y seguros de lo que dicen. Nuestra predilección sabrá inclinarse de todos modos por quienes, como Mutis, intentan en cambio luchar contra la insuficiencia y la vacuidad resonante de las palabras [Subrayado mío, LHVT].

En cuanto a Jorge Gaitán Durán, baste con resaltar las preocupaciones que lo asaltaban, de acuerdo con el testimonio de uno de sus amigos entrañables, gran escritor, Pedro Gómez Valderrama ${ }^{26}$ :

En sus últimos años lo persiguió la idea de la crisis del poema; reunió en $S i$ mañana despierto dos modalidades de su obra, que tienen profundas relaciones, unas evidentes, otras secretas: los fragmentos del "Diario", y la última poesía. Su concepción derivaba a la multiplicidad de formas de expresión poética. Es el caso del libreto de la ópera "Los hampones"; es el caso del "Diario". Gaitán Durán era fundamentalmente un poeta, con el don especial de proyectar su poesía sobre los demás aspectos de una actividad literaria múltiple.

(Es notable señalar que en este prólogo, inmediatamente después de lo citado, Gómez Valderrama muestra un error frecuente en la crítica: "Por ello, al hablar del poeta no me refiero solamente a su obra en verso; tengo que aludir también al "Diario", a sus cuentos y a todo su trabajo de creación". Y habría que añadir que hay que acudir también a las entrevistas (Arango me dijo: "Borges es poeta hasta en las entrevistas"). No se puede separar lo inseparable).

Escasas como son las reflexiones expresas de Aurelio Arturo -también es parca su obra poética: 30 poemas-, las cavilaciones sobre la poesía son intensas. Arango,

26 "Prólogo. 'El regreso para morir es grande"” a Obra literaria de Jorge Gaitán Durán, Biblioteca Básica Colombiana, Colcultura, Bogotá, 1975, pág. 12 
en un ensayo dedicado a este poeta nariñense ${ }^{27}$ : “"Palabra' es un poema fundamental de la madurez. Una escueta - pero no por eso menos rica- meditación sobre la poesía”. El filósofo Danilo Cruz Vélez sobre el mismo poema hace la siguiente declaración ${ }^{28}:$

El tema de "Palabra" es el lenguaje del hombre. Este es posiblemente el primer gran poema sobre este tema escrito en nuestra lengua. Cuando lo leímos por primera vez, en Golpe de dados, quedamos asombrados de que la poesía, es decir, el lenguaje poético, pudiera esclarecer el lenguaje mismo, sacando a la luz aspectos de su ser ignorados por la filosofía del lenguaje y por las ciencias particulares del lenguaje.

En "Lluvias", el gran maestro del ritmo poético se deja llevar por el ritmo del mundo, representado aquí por el fenómeno cósmico de la lluvia. Y ello en tal medida que, leyendo el poema, de pronto parece que el poeta hubiese desaparecido y que la lluvia misma hubiera ganado presencia poéticamente cantando su propia historia milenaria.

En "Tambores", estos, el medio más antiguo de comunicación colectiva entre los hombres, son el símbolo del lenguaje. Y el poeta los oye sonar a través de los siglos y los milenios,

transmitiendo en la tierra hasta muy lejos

la palabra humana

la palabra del hombre y que es el hombre

la palabra hecha de fatiga y sudor y sangre

y de tierra y lágrimas

y melodiosa saliva

El poeta publicó estos tres poemas probablemente como una muestra de algo nuevo que apenas comenzaba a alborear. Si ello es así, y si no se encuentra una continuación del nuevo ciclo en su legado póstumo, se puede decir que con la muerte de Aurelio Arturo en 1974 se hundió por segunda vez en la sombra la promesa de un poeta colombiano de significación universal. La primera vez fue en 1896, cuando muere José Asunción Silva a los treinta y un años de edad.

Rafael Maya es un poeta al que debe volver una lectura filosófica. Para Gutiérrez Girardot, "representa en la literatura colombiana el tipo de poeta doctus que caracteriza a la moderna poesía desde Novalis y Coleridge. El tipo de poeta doctus surgió en

\footnotetext{
${ }^{27}$ José Manuel Arango, "Aurelio Arturo y la poesía esencial", en: Aurelio Arturo. Morada al sur y otros poemas, Norma, Bogotá, 1992, págs. 56, 57.

28 El misterio del lenguaje, Planeta, Bogotá, 1995, Pág. 71.
} 
Colombia demasiado tarde y con demasiadas limitaciones" ${ }^{29}$. Así mismo hay que volver a Holguín. El mismo texto de Gutiérrez Girardot (pág. 534) dice de aquel: "Los ensayos de Andrés Holguín, La poesía inconclusa y otros ensayos (1947) [...] significaron un intento de reflexionar sobre la poesía con propósito filosófico y desde una perspectiva más contemporánea".

Ahora bien: aquí el punto de partida escogido es el poeta colombiano José Manuel Arango. La verdad es que quien me sugirió la necesidad de una lectura filosófica fue la meditación de más de 20 años sobre la obra de Arango. Primero me percaté de que si la lectura de su propia obra no se acompañaba de un enfoque filosófico, permanecería incompleta. Luego me hizo patente la necesidad de hacer lo propio con la poesía colombiana del Siglo XX.

Pero ¿por qué Arango, además de estos argumentos de mi circunstancia? Es verdad que la poesía colombiana del siglo XX aparece "signada" por Zaratustra, a través de su fundador (Paz en el texto "El caracol y la sirena", de Cuadrivio (F.C.E., México, pág. 11) recuerda que en la Breve historia del modernismo, Max Henríquez Ureña dice que Silva era "lector apasionado de Nietzsche, Baudelaire y Mallarmé"30; es

${ }^{29}$ Esto lo señala en la pág. 508 de la "Literatura colombiana del siglo XX". En la siguiente página precisa lo que se debe a Maya: "La ligereza con que se clasificó a Maya como clasicista impidió reconocer sus innovaciones: el 'verso libre', la reflexión sobre la historia presente, sobre la poesía y el poeta, es decir, la intelectualización de la poesía". No veo cómo no se puede adjudicar esa "intelectualización" de la poesía a Silva.

${ }^{30}$ Baldomero Sanín Cano relata de la siguiente manera, en un texto de 1949, el encuentro de Silva con Nietzsche: "Un día vino Silva a verme con un número de la Revista Azul (Revue Bleue) de París, para hacerme leer un artículo de Teodor de Wyzewa, escritor francés de origen polaco, cronista literario durante muchos años de la mencionada revista, acerca de un filósofo alemán de nombre Federico Nietzsche. Comentamos la noticia con grande interés. Había citas curiosas de aforismos del atrevido pensador y nos dimos a buscar la manera de procurarnos sus obras. Silva tenía relaciones con casas editoras francesas, de quienes recibió información de no haber sido traducidas en francés las obras del inmisericorde. Las pedí a los libreros alemanes y me llegaron oportunamente. Entonces no había servicio postal aéreo ni vapores Diesel; pero existían comunicaciones regulares de país a país ("José Asunción Silva”, en Baldomero Sanín Cano, Escritos, Biblioteca Básica Colombiana, Instituto 
verdad que en muchos casos (Mutis, Gaitán, Cote Lamus, Maya, Holguín) hay un sino conceptual, en algunos incluso quizá en el mal sentido. Pero nunca como en Arango aparece un hombre tan preparado desde las dos "Montañas" para mirar el horizonte. En ningún caso en la poesía colombiana se da la conexión con la filosofía como en la obra de este antioqueño: una poesía hermosa se encuentra unida a una reflexión intensa; una obra rigurosa se complementa con una formación exigente. Poesía y prosa reflexionan intensamente sobre la época. Si en algunos de los grandes poetas del siglo XX la reflexión sobre los problemas que nos ocupan es honda no creo que sea tan sostenida como en este antioqueño ${ }^{31}$. La obra de Arango suscita la reflexión filosófica y se nutre de la misma. Por ello quizá se le ha visto como un presocrático en Medellín. Por esa razón la filosofía encuentra en su trabajo un acceso “natural". Por ello también la consideración de la obra de Arango no puede estar completa sin una lectura filosófica. Me parece, finalmente, que la ubicación temporal de Arango ayuda también: su primera obra publicada es de 1973. Su trabajo público abarca el último cuarto del siglo XX. Un buen tramo del siglo para observarlo e incluso evaluarlo, mientras buscaba una poesía adecuada a la época ${ }^{32}$.

Colombiano de Cultura, 1997, pág. 471). En la página siguiente señala Baldomero Sanín: "En sus últimos días no nos veíamos con frecuencia. A veces nos juntaba la casualidad. A veces solíamos buscarnos. En noches tranquilas, lejos de los penosos oficios a los que los dos estábamos uncidos por un burlón determinismo, solíamos comentar lecturas, sucesos; asesinar esperanzas; analizar hombres y tiempos con la libertad que dan el silencio y la confianza. Nietzsche nos ayudaba en estas funciones. El espíritu libérrimo y audaz del que se llamó a sí mismo 'el crucificado' y el transvaluador de todos los valores, suministraba contenido y base para nuestras innocuas especulaciones de rebeldía. Me sorprendió que en adelante, sin conocer de Nietzsche más que esas lecturas fragmentarias, hiciera sobre la obra general del solitario pensador observaciones profundas y sobre todo acertadísimas".

31 Pienso de nuevo, y ante todo, en Silva. De las Gotas amargas, obra de quien calificó un contemporáneo de "filósofo engarzado en un petimetre", dice Charry Lara: "Las Gotas amargas constituyen evidentemente, un cuerpo aislado dentro de la obra de Silva. ¿Son, como se ha dicho, su confidencia filosófica? Existe en ellas algo más directo y descarnado que las aleja de cualquier género de especulación y las sitúa con toda llaneza, con toda exactitud, en la crítica de la conducta humana. ¿Era injusta, a través de esas corrosivas estrofas, la manera de pensar de Silva sobre sus semejantes? No lo pensamos y hay de sobra motivos para creer que hubiese sido más cruel su juicio acerca de nuestros contemporáneos" ("Divagación sobre Silva", pág. 426).

32 En la Antología de la poesía colombiana, en el ensayo consagrado a Arango, da Jiménez Panesso una razón adicional a las ya expuestas: "En la obra poética de José Manuel Arango se compendian casi 


\section{Por qué examinar la versión de Arango}

La indicación hecha sobre la escogencia de Arango es todavía sumaria. Demasiado para un trabajo que propone algo así como el siglo XX en la poesía colombiana visto desde sus ojos, es decir, dejarse llevar por las pistas de alguien que, como él mismo dijo al final de su vida, "iba solo haciendo su camino". En otras palabras: en un trabajo que pretende dejar que Arango proponga unos problemas filosóficos en el desarrollo concreto de esta poesía.

Es preciso considerar en detalle "el caso" Arango. Por consiguiente, el camino que sigue ahora la exposición es el siguiente: ponderación de los rasgos del autor Arango; argumentación de la necesidad de hacer una lectura filosófica, con base en la manera como ven al poeta colegas reconocidos y como se percibe él mismo; y finalmente bosquejo de los límites que puede ofrecer una lectura como la propuesta.

\section{...buscando solo su camino}

Creo que si se examinan las calidades del poeta Arango, la propuesta hecha en este texto, podría recibir adjetivos al uso como "atractiva", "interesante”. Reseñando el libro Montañas, decía, en 1995, el poeta colombiano Darío Jaramillo Agudelo, hasta hace unos años Subgerente Cultural del Banco de la República:

Desde su primer libro, Arango se situó aparte y terminó desempeñando un rol de poeta insular, del mismo modo que lo fueron Aurelio Arturo, Mutis y Mario Rivero para sus generaciones.

Insular y paradigmático, discreto, casi invisible, Arango ha publicado a lo largo de 20 años una de las más hermosas colecciones de poemas de la literatura colombiana. Arango, profesor de filosofía de la Universidad de Antioquia, es también eximio traductor de poetas anglófonos (Dickinson, Whitman y Williams), en nada ajenos a su quehacer poético, a su rigor y a su lenguaje propios.

[...] Arango, gran poeta, ha vivido la Medellín de nuestro tiempo, donde más que en ninguna otra parte "hay gentes que llegan pisando duro... gentes que todo lo

todas las tensiones que caracterizan el desarrollo de la poesía colombiana. Es expansiva y simbólica, pero se contrae con el paso de los años y la madurez" ("Sobre la presente antología", pág. 65). Repito que acabo de conocer este texto. 
consideran suyo que quiebran y arrancan que ni siquiera agradecen el aire". Por eso, no son extrañas las "ocupaciones apacibles": “...y las acciones suben en la bolsa, los aviones salen a la hora prevista, los oidores oyen, los asesinos asesinan. Hay camiones cargados de fruta que hacen cola en la calle del mercado. Un perro orina contra el grueso tronco de la acacia. En fin las ocupaciones apacibles de un momento antes del acabose".

La larga cita de Jaramillo Agudelo se justifica porque en ella -de una manera sintética- destaca una serie de notas que perfilan el autor Arango: "gran poeta", "autor de una de las más hermosas colecciones de poemas de la literatura colombiana", "eximio traductor", "profesor de filosofía" del lenguaje de una de las más importantes universidades colombianas.

Estas notas, a las que habría que agregar las calidades de ensayista (poco destacadas, en general, por la crítica) y su formación académica hacen que los puntos de vista de Arango sobre la poesía colombiana sean de máximo interés (Tal vez hasta ayuden a verla de manera muy distinta a las maneras habituales). El interés no hace sino acrecentarse cuando se considera la dedicación del poeta a su tarea, manifiesta también en la fundación de revistas como Acuarimántima y DesHora, y su presencia en Poesía.

Ahora bien, el propósito de este trabajo no es el de ofrecer un trabajo “interesante" o "atractivo", por el método seguido. Propongo este método porque es el más riguroso posible. Incluso puede parecer de sentido común: puestos a indagar "las preocupaciones centrales" de los poetas del siglo XX, hay que preguntar a quienes más saben de ellas: los poetas mismos. Y entre ellos a quienes estén en mejores condiciones. 
Las de Arango son inmejorables. No es sino observar la indagación realizada en su obra acerca de la poesía, búsqueda a la que le cabe los calificativos de central e "intensa". Para tener una idea de lo que esto significa en la obra de Arango ${ }^{33}$, solo transcribiré el comienzo de mi texto publicado por el Banco de la República (págs. 17 y 18):

Me parece que los mismos títulos de los libros de Arango tienen sabor de poética, o sea que los nombres Este lugar de la noche (1973), Signos (1978), Cantiga (1987) y Montañas (1995) parecen señalar que su poesía es en buena parte una indagación sobre la poesía. Esto ya lo había planteado en mi ensayo "Cosas a un tiempo familiares y ajenas" (2001), texto que me permitió conocer el poeta y entrevistarlo. Daba allí las siguientes razones. Presente en el título de su primera publicación, la noche recorre su obra. Cuando con "La bailarina sonámbula" dice lo que para él es la poesía, afirma: "Es de noche, naturalmente". Tal vez más que la noche lo obsesiona el anochecer (el "umbral" del anochecer). Signos: en sus poemas, unos pocos rasgos, puestos con cuidado, son indicios, señales que guían hacia lo que apenas sugieren. Cantiga. Uno de los sentidos de este vocablo es el de breve composición poética. Esta es una de las peculiaridades de la poesía de Arango: una, dos, tres frases. Claro que hay poemas largos, pero incluso estos generalmente parecen estar constituidos por fragmentos. Finalmente, aparte el libro, ¿cuántas veces están las montañas en estos poemas? ¿No dice que las montañas forman parte de ese nosotros del último poema de Montañas: "Estas montañas hoscas/ que se adelgazan,/ que se ensimisman en nosotros./ Ya sólo acaso una manera/ de la voz,/ del paso,/ del gesto?" En suma: los títulos señalan cosas familiares (noche, montañas), modos de ser de la obra (signos, cantiga) que al tiempo son ejes de la "visión", es decir, que entran en la manera misma de ver y de "pararse a ver". Mirada de montaña. Paso, voz y gesto de montaña. Mirada de noche. Cosas que son signos. Preocupaciones. Preocupación en esos sentidos de la palabra que lindan con el interés, la obsesión e incluso el capricho.

En la indagación hecha por Arango en su obra poética, la escritura, el autor, el lector, la obra, la poesía, los sentimientos propios de los estados poéticos, dejan imágenes para pensar. Mucho que dejar-por ahora- fuera en estas reflexiones. A la habitual consideración de la poesía como sueño se unen otras metáforas (el lenguaje gestuno) o se hace más honda la representación habitual (la poesía es una bailarina sonámbula que lleva los ojos abiertos o la poesía es una moneda que marca el poeta

33 Creo que 17 poemas de los 265 recogidos en la Poesía completa publicada por la Universidad de Antioquia en el 2003 pueden ser calificados sin discusión como poéticas. Este es el caso de 5 poemas de Este lugar de la noche, 2 de Cantiga, 5 de Montañas, 4 de "Otros poemas" y 1 de los poemas "Póstumos". En adelante, las citas de la poesía se Arango remiten a esa edición. 
con la uña, dejando una huella casi imperceptible y que, rodando por la ciudad, busca a un lector incierto que ve esa huella en la palabra cotidiana). En esta búsqueda de una poesía para nuestro tiempo sin duda le ayudaba al poeta Arango el profesor de filosofía del lenguaje. Lo dice de una manera precisa en una entrevista concedida a la influyente poetisa colombiana Piedad Bonnett ${ }^{34}$ :

A mí, como te digo, me ha interesado siempre el lenguaje, las maneras como trabaja. O sus mecanismos, su funcionamiento, si se quiere usar una expresión prosaica. Pero sobre todo el misterio del lenguaje, o el enigma que en el fondo es el hombre mismo. En los niños sordos, los niños privados de la palabra, se pueden ver esas delicadezas. Una vez fui a la Escuela de Ciegos y Sordomudos de Medellín y me fascinaron los niños sordos. Seguí yendo y observando, traté de aprender el lenguaje de señas o por lo menos de estudiarlo, vi cómo se hace para enseñarles, porque ellos tratan o trataban en aquel tiempo, de enseñarles a hablar. A veces llevaba a mis estudiantes. Mis cursos en la universidad eran fundamentalmente de estudio del lenguaje, hasta el lenguaje algebraico de la lógica me interesó un tiempo. $\mathrm{El}$ hecho es que en los sordos de nacimiento se puede ver mejor lo que es el lenguaje para nosotros, todo eso que damos por natural, en lo que no nos detenemos, toda esa complejidad y esa fragilidad de la palabra [...] ya sabemos que el lenguaje es lo que nos hace [...] el lenguaje de señas, un lenguaje silencioso que parece hecho de jeroglíficos, puede ser como una metáfora de la poesía.

Que el "mirador" del poeta Arango es de amplias perspectivas lo dicen las calidades reseñadas. Pero hay más: el antioqueño, autor de una poesía cada vez más meditativa, tiene observaciones "agudas" sobre la poesía colombiana. Basta mirar sus ensayos. Y las entrevistas que concedió. Sus observaciones pueden calificarse de inusuales $^{35}$. Me detendré solo en dos de ellas. La primera está en la entrevista citada ${ }^{36}$ :

A mí Silva no me cansa. Siempre encuentro en él algo nuevo, una hondura o un matiz. Desde el comienzo me fascinó por la música y la sencillez del lenguaje, porque a pesar de su modernismo es un poeta de una gran sencillez de lenguaje. Ya sabemos que él es el iniciador de la poesía moderna en Colombia, el que la puso en

\footnotetext{
34 "Entrevista con José Manuel Arango", en: José Manuel Arango, La tierra de nadie del sueño. Poemas póstumos, Ediciones DesHora Intergraf, Medellín, 2002, págs. 62, 63 (La entrevista forma parte del libro Bonnett, Piedad, Imaginación y oficio. Conversación con seis poetas colombianos, Colección Celeste, Editorial Universidad de Antioquia, Medellín, abril de 2003).

35 Ya me detendré en afirmaciones que literalmente constituyen un "porrazo", porque chocan fuertemente con lo que uno "se imagina", porque obligan a pensar; pero acá solo me concentraré en dos. Coloquemos de paso unos ejemplos adicionales: la negativa a definir la poesía; la crítica a la presunta tradición de la pobreza de nuestra poesía, tópico de varios críticos - y poetas- colombianos; la reflexión sobre la inconveniencia de hablar de poesía "colombiana", y la reivindicación de la expresión "la patria es la lengua".

36 Pág. 67.
} 
este tiempo. Es como el padre muerto joven de todos nosotros. Todavía vivimos, me parece, en la problemática que él planteó. La pregunta por la técnica y el progreso, la pregunta por la posibilidad de la poesía. El desgarramiento, el conflicto de Silva han sido muy fecundos. Dice que el verso es vaso santo y que sólo se puede poner en él un pensamiento puro, y sin embargo escribe las Gotas amargas, que son mucho más agresivas que la antipoesía que vino después, incluida la de Luis Carlos López.

Yo creo que la oscilación que se ve en la poesía de hoy - ¿o ya es de ayer?- entre antipoesía y búsqueda de caminos más oblicuos o secretos para celebrar, eso ya estaba en Silva.

Valdría la pena comentar en extenso este texto. Es inquietante esa mención del "desgarramiento" de Silva. Por otra parte, la mención al Modernismo ("a pesar de su Modernismo”) recuerda el lenguaje a veces excesivamente complicado de otro de los padres de este movimiento, Rubén Darío, y de algunos “descendientes” colombianos de Silva. Hay que recordar que, a propósito del verso del "Responso a Verlaine", del nicaragüense ("Que púberes canéforas te ofrenden el acanto”), decía García Lorca que la única palabra que allí entendía era la palabra "que". También podríamos pensar en las palabras, poco corrientes, por lo general, de Barba Jacob en el enorme poema que es la "Canción de la vida profunda" ("próvido", "sórdidos", "lúbricos", “ineluctables”). O en León de Greiff: “La cántiga ondulosa de su trémula curva/ no ha mecido mis sueños;/ ni oí de sus sirenas la erótica quejumbre;/ ni aturdió mi retina con el rútilo azogue/ que rueda por su dorso". Palabras sencillas, de todos los días en Arango y en Silva $-Y$, agreguemos por su importancia para Arango, en Machado ${ }^{37}$.

\footnotetext{
${ }^{37}$ No se ha estudiado la relación Arango-Machado, ni siquiera en textos tan logrados como el ensayo de David Jiménez sobre su poesía. En la entrevista concedida al cubano Rodríguez Nuñez ("La poesía es eficaz, nos cambia", Magazín dominical, El Espectador, $\mathrm{N}^{\circ}$ 632, 25 de junio de 1995, pág. 8) dijo Arango al cubano:

"Víctor Rodríguez Núñez: De ti han dicho que tomas "distancia de la verbosidad y grandilocuencia" de cierta poesía. ¿Asientes?

“José Manuel Arango: En los poetas que primero me llegaron encontré ese tono, como de quien conversa en voz baja. Antonio Machado, digamos. O José Asunción Silva que, según sus propias palabras, intentaba hablar "al oído del lector". Es curioso que ambos vengan, de algún modo, de Bécquer, quien distinguía ya entre una poesía elocuente y lujosa, y otra más escueta y desnuda. De los
} 
Igualmente notable es ver el "conflicto" de Silva entre "antipoesía y búsqueda de caminos más oblicuos o secretos para celebrar". Quizá el señalamiento de esas dos vías -como creo que lo han resaltado otros poetas colombianos- es fructífero para ver el recorrido de la poesía colombiana en el siglo XX.

No obstante la pertinencia de estas dos notas de la poesía abierta por Silva, me parece que lo más destacado de la afirmación de Arango está en la reivindicación de la tradición en la que se inserta su trabajo y en la manera de formular esa reivindicación: "Es como el padre muerto joven de todos nosotros. Todavía vivimos, me parece, en la problemática que él planteó. La pregunta por la técnica y el progreso, la pregunta por la posibilidad de la poesía". Resalto en primer lugar la conciencia de la circunstancia histórica. Esta frase deja extrañas sospechas: es como si todo un proceso histórico cobrara conciencia en este poeta, en un momento en que podría haberse pasado a otra cosa: “¿O ya es de ayer?” Por otra parte, hay que examinar la manera de poner Arango el problema de Silva y la manera de plantear Hugo Friedrich ${ }^{38}$ el problema de Baudelaire). Arango habla con precisión de teórico o con términos propios de filósofo. El contraste es fuerte con la metáfora de la frase anterior: "Es como el padre muerto joven de todos nosotros" (¿Cosas de la edición

que he frecuentado después, la mayoría tiene también esa cualidad. Emily Dickinson o William Carlos Williams, para mencionar dos solamente. Ninguno de ellos declama o predica: hablan, simplemente".

La presencia fuerte de Machado en Arango me la confirmó Elkin Restrepo de la siguiente manera -En la entrevista hizo esta afirmación, entre otras-: "Yo creo que a J.M. no le importaba el reconocimiento -que lo tuvo, y que por supuesto nunca buscó-. A él nunca le interesó tener éxito, triunfar, ser alguien, estaba por encima de eso. Quería cumplir lo suyo y su paradigma era Machado, el poeta de provincia, que no le hace el juego ni al poder ni a nada. En esto era ejemplar".

38 "Varias son las manifestaciones en las que se lo califica como "poeta de la modernidad". Y ello está perfectamente justificado, porque Baudelaire es el inventor de esta palabra. La usa en 1859, excusándose de su novedad, pero la necesita para expresar lo que caracteriza al artista moderno, es decir, la facultad de ver en el desierto de la gran ciudad no sólo la decadencia del hombre, sino también una belleza misteriosa y hasta entonces no descubierta. Éste es el problema del propio Baudelaire: ¿Cómo es posible la poesía en una civilización comercializada y dominada por la técnica? Sus poemas nos indican el camino; su prosa nos orienta teóricamente": Hugo Friedrich, La estructura de la lírica moderna. De Baudelaire hasta nuestros días, Seix Barral, Barcelona, pág. 47. 
de la entrevista?) Ve en su propia poesía a Silva, como ve a su padre en uno de los más hermosos poemas de Este lugar de la noche: "A veces/ veo en mis manos las manos/ de mi padre y mi voz/ es la suya/ [...] cara detenida de mi padre/ bajo la piel, sobre los huesos de mi cara" (No estaría mal que un ensayo se consagrara a ver los dos problemas tanto en Silva como en Arango).

Conciencia de la tradición en la que se inserta, honda reflexión poética sobre la poesía, conciencia de la búsqueda obsesiva de su música, de su sencillez, y ¿̇su ironía? Agreguemos ahora: conciencia de lo que he llamado antes y llamaré ahora, provisionalmente, "preocupación fundamental". Ella está expresada en una "Nota", escrita para la antología publicada por la revista Palimpsesto, de Sevilla, España, texto que consideraremos en detalle en el capítulo sobre poesía y razón. Poesía como ocupación con lo sagrado, "aniquilación de la realidad en el misterio", como más o menos han dicho. Aquí hay conciencia, pero ahora de lo que he llamado "preocupación central" en esa "reflexión sobre lo que somos". Digo preocupación pero pienso en metáforas como "intuición central", "hilo conductor". "Origen" dirían tal vez algunos alemanes. Y brotan las preguntas: ¿esa poesía de este tiempo, pero que podía ya ser de ayer, ha tenido desde Silva esta problemática? ¿El misterio explícito en Silva tiene que ver con lo sagrado? ¿Está también en Valencia, Barba y en De Greiff, en Aurelio y Mutis? ¿Es ese misterio el que para los poetas está en juego en el acercamiento a las cosas y a los hombres (entonces a nosotros mismos) ¿Está expresada acá "la" función de la poesía para Arango, una función política en el más noble sentido? ¿Formulación que solo puede ocurrírsele a un gran poeta en "el país más violento del mundo”, como señaló José Manuel en una entrevista? ¿Han estado “advirtiendo" los poetas a los colombianos las consecuencias de negar lo sagrado, esa sobre-naturaleza que también baña a "los pícaros y tahúres y matones que ahora nos 
acorralan"? ¿O todo esto no es otra cosa que "prédica de cura viejo", como dice Arango de la manera como tomaron algunos las reflexiones del pensador antioqueño Fernando González?

La afirmación de Arango en esa "Nota" ("Creo que hay una manera más comprensiva de acercarse a las cosas y a los hombres y que está justamente en la poesía") deja entender un par de expresiones de Arango contenidas en la entrevista ya reseñada de Rodríguez Núñez: "La poesía nos enseña a ser... mejor, a no ser" y "la poesía no es útil, es eficaz: nos cambia". Puede la poesía cambiar la manera de abrirnos, de franquearnos a las cosas, a los demás y a nosotros... en este "momento antes del acabose". Aquí contrapone Arango la manera de acercarse a las cosas y a los hombres que pone en juego la poesía y la manera de acercarse a las cosas y a los hombres que desarrolla la prosa, "herramienta del intelecto". Dice en efecto en el párrafo anterior:

Pero el poema, más que de una visión del mundo, surgirá de lo que Unamuno llamó un sentimiento de la vida. Está hecho no sólo de enunciados, de afirmaciones y negaciones, sino de los verbos y sustantivos de una lengua que tiene una historia, de palabras que por sus sonoridades y cadencias despiertan ecos y asociaciones, está hecho de imágenes y de ritmos, de rupturas y silencios. Por eso es difícil decir en prosa, herramienta del intelecto, lo que dice o muestra un poema si es verdadero, lo que bregan por decir esos textos fallidos en los que generalmente nos quedamos.

Distancia entre el concepto, el juicio, y la palabra poética. Señalamiento preciso del hiato existente entre la prosa -incluso si es la del mismo poeta- y sus poemas. La distancia se mantiene incluso si la prosa toma, como en la cita de que partimos, la vía de la creencia (“Creo") y por tanto asume la penumbra del enigma. Distancia entre la prosa y la poesía; distancia entre las creencias y opiniones de un autor y lo que sale en un poema, por fuerza indecible e incierto. Con toda razón, un 
poeta coetáneo de Arango, Giovanni Quessep, académico como él, dijo en otra de las entrevistas $^{39}$ de Bonnett (Pág.46):

Piedad Bonnett: Y hay otra cosa que me parece que hay en tu poesía, que es búsqueda... Siempre un buscar, un preguntar.

Giovanni Quessep: Sí. A veces, obviamente no sé qué es lo que estoy buscando. Si lo supiera, no volvería a escribir, eso es cierto. Pero sí hay una búsqueda siempre, como si algo se me hubiera perdido, como si hubiera olvidado algo y quisiera recordarlo intensamente; y yo no hago más que preguntar y preguntar y preguntar. Nadie me responde por supuesto. (Risas)

Las calidades de Arango son notables, como se puede ver. Poeta, traductor, profesor de lógica y filosofía del lenguaje, ensayista. E insisto aunque le tengo una enorme desconfianza a la palabrita: "conciencia" de su tradición poética y conciencia de su labor. Creo que José Manuel comparte con Silva y Aurelio la cercanía a poesía en lengua inglesa. Pero es una cercanía particular, que contribuye a determinar sus peculiaridades. Terminemos esta enumeración de las calidades de Arango con alguna precisión del carácter de su poesía, desde el punto de vista de otro poeta: Juan Manuel Roca. Veamos lo que este le dijo a Piedad Bonnett ${ }^{40}$ :

Piedad Bonnett: En la poesía más contemporánea ¿reconocerías algunas corrientes susceptibles de definición y podrías inscribirte en alguna de ellas?

Juan Manuel Roca: Yo creo que sí hay algunas vertientes más o menos claras: que hay una vertiente, digamos, coloquial, que intenta atrapar lo cotidiano a través de la palabra, que propone un prosaísmo a propósito, a la cual difícilmente yo me vinculo. Que hay otra vertiente de una poesía intimista, de un lirismo muy puro y muy decantado que quizá venga de la tradición de Aurelio Arturo y de Fernando Charry Lara, una vertiente que respeto mucho, pero en la cual tampoco me involucraría. En la última mencionada estarían, por ejemplo, Giovanni Quessep y Jaime García Mafla, fundamentalmente.

Piedad Bonnett: ¿José Manuel Arango se inscribiría, o no, en esta corriente?

Juan Manuel Roca: José Manuel Arango sí, pero de una manera un poco ecléctica, un tanto espuria; yo diría que podrían introducirse algunos de sus poemas

39 "Giovanni Quessep", en: Bonnett, Piedad, Imaginación y oficio. Conversación con seis poetas colombianos, Colección Celeste, Editorial Universidad de Antioquia, Medellín, abril de 2003, pág. 46.

40 Ibídem, págs. 105, 106. 
o algunas de sus preocupaciones dentro de esa vertiente, pero que tiene también otras que le vienen más que del tono hispano cercano a Cernuda que hay en Charry Lara, más que de la poesía española, de la poesía norteamericana. A veces yo pienso que los poemas de José Manuel Arango parecen traducciones de poetas norteamericanos; eso no lo digo en contra de su poesía... Me parece que ha bebido tanto en esa poesía, que de pronto su poética está saturada de esa expresión tenue, muy rigurosa en la elección de la palabra, que encontramos quizá en Emily Dickinson. O sea que es otra vertiente diferente a la ya señalada de Quessep y García Mafla. Pero José Manuel Arango tiene también otra línea de su poesía que se mueve en una preocupación por su entorno, por definir las cosas de sus Montañas, de su región, en la cual encuentro también una cercanía con la dicción de un orbe más filosófico, aunque a veces poético, que tenía Fernando González, que tenía inclusive Epifanio Mejía. Siento que de pronto esa preocupación por ser de un sitio, de una región, de una geografía muy específica, y en este caso tan fuerte como la escenografía antioqueña, se da en José Manuel Arango con momentos muy bellos.

Arango estuvo a finales de los sesenta $(69,70)$ en los Estados Unidos, según cuenta en entrevistas. Haciendo una maestría en Filosofía y literatura. Tuvo ahí el encuentro definitivo (Le ayudó a encontrar su camino) con el movimiento Black Mountain. Poetas como Denis Levertov, Robert Bly venían de Pound, Wallace Stevens, William Carlos Williams, de lo que se llamó imaginismo. Era una especie de corriente alternativa a la de los Beats, de Ginsberg, Corso, Snyder. Habría que hacerle la precisión a Roca que el movimiento de Black Mountain tenía una curiosa cercanía con la poesía en lengua española, como lo señaló Arango en una entrevista concedida a la revista Babel ${ }^{41}$. Dice allí:

...Era una poesía que no solo venía del Imaginismo sino que tenía mucha influencia de la poesía hispanoamericana, en la que uno había crecido. De Antonio Machado, de Juan Ramón, de Neruda, de Vallejo. Por esos años precisamente salió una antología de la nueva poesía norteamericana con el título de Poesía desnuda, Naked Poetry. Tenía como epígrafe unos versos de Juan Ramón y de uno de ellos se tomaba el título ${ }^{42}$.

Por otra parte, es cierto que en la obra de Arango hay una raíz antioqueña, pero también hay una raíz del altiplano, como él mismo señaló varias veces: en el altiplano,

41 “Conversatorio con José Manuel Arango. El excesivo pudor", Babel, N 4, Medellín, Diciembre de 1996 - Marzo de 1997, pág. 15.

42 Influencias, una palabra a la que le da vueltas: Arango habla también de "inoculaciones". En la "Nota" de la Sombra de la mano en el muro, agrega a esto: "Estas transfusiones -más que traducciones-son seguramente fecundas. La poesía donante es transformada y asimilada y el resultado es un diálogo enriquecedor. En las últimas décadas, me parece, la poesía hispanoamericana ha recibido a su vez un influjo benéfico de la norteamericana". 
en la ciudad de Tunja, a unas dos horas de Bogotá, estudió el pregrado en filosofía y educación, se casó, tuvo dos hijos y trabajó como profesor cuatro años. Él mismo dijo que el vínculo con el altiplano cundiboyacense era para él entrañable y que aparecía en sus dos primeros libros.

\section{O [por el lado] metafísico, si se quiere}

Para muchos poetas colombianos notables, Jaime Jaramillo Escobar es el gran poeta del nadaísmo. Se dio a conocer como X-504, y así se quedó. A José Manuel y a otros poetas les he oído referirse a él como "X". Su primer libro se llamó Poemas de la ofensa (Premio nadaísta de poesía "Cassius Clay", 1969). Recientemente (2004) la Universidad Externado de Colombia publicó una antología de este libro, que tiene como "Envío: A los que no necesitan estudiar cosas raras para comprender la poesía". Mencionar esto parece un buen comienzo para sostener la tesis que una lectura hecha desde la obra de Arango tiene que ser necesariamente filosófica, por muchas razones, entre otras que este cogió a Fernando González por el lado metafísico ${ }^{43}$. Habría que ver si el "Envío" es una de las bromas habituales de X, porque ¿dónde encontrar ese lector no contaminado por interpretaciones? ¿Quería dejar sin trabajo a los críticos, por otra parte? La lectura de "cosas raras", además, no es exclusiva del Arango que estamos hablando. Otro Arango, Gonzalo, El profeta, fundador del nadaísmo, según $\mathrm{X}$ tenía las mismas costumbres ${ }^{44}$ :

Hernán Arango tomaba menta en el café de Cuco Martínez, en Andes,

43 Babel, N 4, Medellín, págs. 17 y 18:

“Babel: ¿En qué punto se encuentra con Fernando González en la ironía contra todo esto? “José Manuel Arango: Por ejemplo, en aquel verso "Los senos son lo primero que se pudre". En él, claro, no es un verso, pero suena como un verso tremendo.

“Babel: Los nadaístas lo toman por el lado panfletario y usted lo toma por el lado erótico.

"José Manuel Arango: O metafísico, si se quiere"

44 Jaime Jaramillo Escobar, "Los años 40", en: Doce poetas nadaístas de los últimos días, Compilador Jotamario, Centro Colombo Americano, marzo de 1986, Págs. 37, 38. 
por 1947 y 1948 ,

transparentes copitas de menta verde y helada, que se sentaba a tomar solo, en redondas mesas esmaltadas,

mientras escuchaba aquella canción en el traganíqueles:

"Padre nuestro que estás en los cielos,

que todo lo puedes, que todo lo ves,

por qué me abandonas en esta agonía,

por qué no te acuerdas de hacerlo volver..."

La canción estaba impregnada de una melancolía suicida,

y a las tres de la tarde del sábado, en la plaza de Andes,

los ángeles lloraban goticas de menta verde.

Mientras tanto su hermano Gonzalo estudiaba a Aristóteles y a santo Tomás, a Hegel y a Kant,

a Heidegger, a Nietzsche,

y leía a Hölderlin.

Me decía: - "Poeta, ¿te das cuenta de estos locos?”

Y yo no me daba cuenta porque estaba nadando en el río, y ese no era el río de Heráclito sino el río san Juan donde los muchachos nos bañábamos desnudos. Gonzalo Arango se sentaba con Sartre y con Camus sobre una piedra a comer guayabas,

y una tarde que Sartre se cayó al río y se ahogó, Gonzalo se puso Tristísimo porque los libros había que encargarlos a Medellín y esa operación resultaba demorada y riesgosa,

ya que a veces le traían a uno un Plotino por un Platón, o un Tito Livio por un Polibio, y le decían: - “Pues léase éste, que es más o menos parecido!”

Hay varias razones para sostener la tesis indicada. En primer lugar, la lectura debe ser filosófica porque necesariamente hay que involucrar temas de filosofía para despejar equívocos. Comencemos por la manera como ha sido recibida la obra de 
José Manuel entre poetas reconocidos. Dicen con una frase más o menos pomposa que la interpretación hace parte de la obra -Y más si es la que hacen los otros poetas. William Ospina en un ensayo sobre Arango, recogido en el libro de ensayos sobre poetas colombianos titulado Por los países de Colombia y que apareció publicado, entre otros varios lugares, en el libro de donde sacaremos la cita, dice que la mirada de Arango está regida por Heráclito ${ }^{45}$. La afirmación no puede ser seria, y creo que José Manuel la recibiría con cierta burla benévola, que se puede adivinar en la siguiente parte de la conversación con Babel, donde comenta una afirmación semejante (No creo que sea la misma, pero es igual el despropósito) ${ }^{46}$ :

Babel: Alguien dice que usted es un filósofo presocrático, como quien dice Heráclito en Medellín.

J.M.A: Sí, sí. Dice que lo mío es la Grecia antigua. Que una flauta que aparece en un poema es la flauta de Pan o algo así. Pero ese es un poema sobre Junín, el Junín de la época, cuando Crescencio Salcedo vendía flautas en la esquina de Junín con la Playa. Uno pasaba y ahí estaba el viejo, bizco y parecido a un sátiro, tocando su flauta.

Babel: ¿A usted le molestan las críticas?

J.M.A: No mucho. Unas me enseñan; con otras, me divierto.

\footnotetext{
45 “José Manuel Arango La radical extrañeza de todo", en: José Manuel Arango, La tierra de nadie del sueño. Poemas póstumos, Ediciones DesHora Intergraf, Medellín, 2002, pág. 81. La frase en la que se sitúa la afirmación es la siguiente: "En otro poema nos dice: 'agosto/cuando el calor tuerce las puertas', y eso basta para que sintamos el trabajo de lo impalpable sobre lo macizo y lo firme, la omnipresencia de esas leyes que gobiernan el mundo, y que no se revelan a los sentidos sino al juego de nuestras facultades. Pero también sentimos la evidencia de que el mundo no descansa, de que la vida obstina su trabajo, su miel y su polen, sus alas atareadas sobre las cosas, de que nada está ocioso y nada está quieto aunque parezca abandonado a su sueño. Heráclito gobierna esta mirada".

${ }^{46}$ En su ensayo sobre Williams Carlos Williams (Whitman, Dickinson, Williams. Tres poetas norteamericanos, Norma, Bogotá, 1991, pág. 54, transcribe Arango unas frases del poeta y médico: "No podemos creer que [la poesía] pueda ocurrir en nuestras vidas, en nuestras propias vidas, sabe, como si fuéramos griegos muertos hace dos mil años". "Pero hay que acostumbrarse a que la propia vida, la que a uno le concierne, puede proporcionar material para la poesía".
} 
Hay errores más comprensibles, como el que comete el poeta Ramón Cote Baraibar cuando afirma ${ }^{47}$, reseñando el libro que sacó la Universidad de Antioquia cuando otorgó a Arango el Premio Nacional de Poesía por Reconocimiento (Poemas escogidos. José Manuel Arango, "Premio Nacional de Poesía", Universidad de Antioquia, Medellín, 1988, 333 págs.):

Un segundo hilo conductor es acercarse a los objetos para nombrarlos en la totalidad de su misterio: en todo lo que nombra busca aquello desconocido que lo alienta, y es aquí donde hace suya la sentencia de Heráclito: "Todas las cosas están llenas de dioses".

Otra vez Heráclito. La frase en realidad es de Tales de Mileto. La de Heráclito es parecida: "-Seguid, aquí también hay dioses". Pero hay que decir que el mismo Arango ayudó a esta percepción de su obra. En efecto, su primer libro apareció con el epígrafe de Diógenes Laercio: "Tales dijo que la substancia de las cosas es el agua y que todo está lleno de dioses”. Después se lo quitó, pero el “daño” estaba hecho. Por otra parte, se convirtió en chiste el hecho que Arango fuera profesor de lógica. Miremos una parte de la conversación con Babel:

Babel: ¿Qué filosofía enseñaba, teniendo en cuenta que era el momento del marxismo, de los paros universitarios?

J.M.A.: Ninguna filosofía dogmática; me interesaban más las preguntas. Principalmente me dedicaba a la filosofía del lenguaje.

Babel: Hay una afirmación de Salvatore Quasimodo acerca de que los poetas son enemigos naturales de los filósofos.

J.M.A.: Todo lo contrario; me parece claro que la poesía y la filosofía tienen una misma raíz: el asombro, la maravilla. Los primeros filósofos eran poetas, muchos de ellos escribieron en verso. Después la filosofía se fue separando de la poesía, se hizo más racional y sistemática. Pero recientemente ha vuelto a darse una coincidencia. Por ejemplo, con Nietzsche, Unamuno o Heidegger; ahí están Bruno y Pascal.

Babel: ¿No hay una escisión, una paradoja, entre la razón y el sentir?

J.M.A.: Realmente sí parecería. Ya los amigos ante la aparente paradoja, empezaron a hacerme un chiste con eso. Y por ejemplo cuando alguno publicaba un

47 “Todas las cosas están llenas de dioses, decía Heráclito", en: Boletín cultural y bibliográfico, Vol. XXVI, $\mathrm{N}^{\circ} 21,1989$. (Tomado de internet) 
poema mío, lo acompañaba de una nota que decía que yo era profesor de lógica. Pero de hecho la lógica era apenas uno de los aspectos de la filosofía del lenguaje. En los últimos años incluso me dediqué especialmente a tratar pensadores latinoamericanos.

Babel: ¿Qué pensadores?

J.M.A.: Hice un curso sobre Fernando González, Sarmiento, Martí, Paz, Andrés Bello, Bolívar, Mariátegui.

Babel: Para un profesor de lógica, el lenguaje es algo preciso. Usted afirma que la poesía es algo irracional, algo que brota de una parte oscura, como un sueño. ¿Qué se hace el profesor de lógica?

J.M.A.: Ahí sigue, supongo. Pero, ¿para qué insistir en eso? Lo de profesor de lógica es una etiqueta, una suerte de estereotipo. Es verdad que durante un tiempo me fascinó la lógica, que es también como el álgebra, parecida a un juego. Tal vez me quedó la intriga desde que vi que la lógica puede aparentemente demostrar a Dios y también que no es posible demostrarlo. Tal vez quería averiguar qué hay ahí. Si se ahonda un poquito en la lógica se encuentra que es también una especie de crítica de la razón. Hay teoremas o metateoremas, que muestran los límites de las formas matemáticas de prueba, que en el fondo son las mismas de la razón. Qué pueden hacer y qué no. Por ejemplo, hasta dónde puede llegar un computador. Así se puede demostrar que un computador no puede manejar conjuntos infinitos de cierta especie. Mucho menos se puede esperar que demuestre la existencia de Dios.

Podríamos aducir más ejemplos en la misma línea. Por ejemplo la presunta ascendencia, en la obra de Arango, de Empédocles y Anaximandro y otros presocráticos y hasta Dionisos (Según Babel, El primer artículo que se publica sobre la obra de Arango se titula "Dionisos en Medellín"). Pero vale la pena mostrar otra cara de la interpretación de la obra de Arango por otro poeta. En 2006, la Colección de Poesía de la Universidad Nacional de Colombia reeditó el primer libro de Arango. En el prólogo, el poeta Mario Jursich afirma que la poesía de Arango bordeó el precipicio consistente en escribir versos filosóficos ${ }^{48}$ :

En cada uno de los libros posteriores -en Signos, en Cantiga, en Montañas y hasta en el volumen póstumo de La tierra de nadie del sueño-Arango dio vueltas en torno a este tema de las deidades perdidas. Lo cual, tal vez de manera inconsciente, lo llevó a compartir un tipo de poética que siempre acompaña a los románticos: la idea de que la poesía debe ser un desciframiento, un develamiento de la realidad que está ante

48 "Prólogo. Las deidades perdidas", en: Este lugar de la noche, Colección de Poesía, Libro recobrado, Universidad Nacional de Colombia, Bogotá, 2006, pág. 14. 
nuestro ojos y que, no obstante, esconde un más allá, una realidad ulterior que nunca debemos confundir con las que pregonan las religiones establecidas.

En muchos poetas (y Arango bordeó en ocasiones este precipicio) esa doctrina los ha conducido a escribir versos filosóficos, poemas en los cuales la "realidad", el "mundo", la "naturaleza" no son más que los "signos" de una realidad superior que, finalmente, vendría a ser la verdadera.

El texto basta para mostrar la percepción de la obra de Arango. (De paso: En los textos citados en que la filiación presocrática de Arango se ha enunciado aparecen creo errores de la crítica que habría que enfrentar: la mala costumbre de no poner ejemplos, afirmaciones disparadas sin sustento, hablar de lo que no se conoce). Esta manera de ver que liga la poesía de Arango con la filosofía, presente en los poetas, la podemos ver de otro modo en la edición de la largamente citada Babel. De hecho el nombre completo de la revista es Babel. José Manuel Arango. La celebración del poeta. Grupo de discusión. Además de la entrevista que he citado, contiene testimonios de alumnos de José Manuel, de amigos, textos de diversos autores, un par de ellos conocidos, los otros no tanto. Parecería que el equipo responsable de la publicación forma parte del grupo de amigos al que se refirió Elkin Restrepo, poeta antioqueño muy cercano a José Manuel, cuando lo entrevisté en $2004^{49}$ : “Al final de la vida de J.M., en torno suyo, se fue formando un grupo de amigos, gente de diversa idiosincrasia, que le manifestaban una gran devoción y que actuaban casi como sus discípulos..." La publicación Babel es una de mis favoritas (sobre todo, la entrevista, de una atmósfera de cercanía cálida, y hasta juguetona). Puede que el diseño de la revista sea artesanal, un poco descuidado, pero dice mucho. Acompañando los textos, aparecen el facsímil de un manuscrito del poeta, fragmentos de críticas de autores reconocidos - que excitaron los furores de alguno que conozco-, un dibujo que representa a Epifanio Mejía, uno de los poetas antioqueños más queridos por

49“José Manuel Arango. Conversación con Elkin Restrepo”. Ver “Apéndice”. 
Arango, un dibujo que muestra el rostro de Arthur Schopenhauer, facsímiles de las carátulas de las obras de Arango, de un alfabeto de ciegos, de un lenguaje para sordomudos, de revistas en las que participó, un par de dibujos que representan a Arango, sendas figuraciones de Borges, Barba Jacob, Aurelio Arturo, Vallejo y Pessoa y muchos, muchos dibujos que representan la muerte. Acertaron colocando imágenes de autores y cosas cercanos al poeta. Parecería, entonces, que Arango y la filosofía son indisociables. Y aquí aparece un segundo argumento. No solo hay que hacer una lectura filosófica para "desfazer agravios y enderezar tuertos". Creo que la mirada de Arango es fácilmente rotulable de "filósofica" -por eso quizá lo vieron los críticos o como un Heráclito o un Empédocles o incluso un Dionisos (con el ascenso de rango de filósofo presocrático a dios) de Medellín-. Por esto y su insistencia poética en espacios premodernos. Una observación atenta de la obra de este antioqueño desazona: Sí. Es poesía. Pero no solo podría admitir el calificativo de filosófica, sino que cada vez me parece más una extraña forma literaria que podría estar conjuntando las dos disciplinas. Ya vimos cómo él mismo dice que un verso - del que acaso es el mejor de sus poemas- es metafísico. Claro que así como habría que precisar con exactitud la noción de filosofía que cabe asignarle (de ningún modo racionalista) también hay que precisar la noción de metafísica. Porque esta puede significar muchas cosas. Él mismo señala en uno de los textos ya citados que no habla de trasmundos ("Siempre me ha acompañado la convicción de que lo sagrado, lo que Lezama Lima llama sobre-naturaleza, no puede negarse impunemente. Sólo que no es cosa del otro mundo"). Precisar esas nociones no es asunto de este capítulo, pero he llegado en parte a una conclusión similar a la del crítico David Jiménez Panesso ${ }^{50}$ :

50 “La poesía de José Manuel Arango", En: José Manuel Arango, La tierra de nadie del sueño. Poemas póstumos, Ediciones DesHora Intergraf, Medellín, 2002, pág. 130. 
Hablamos/ y el vaho de la boca va a añadirse a la niebla", dice un poema de Montañas. En estos dos versos no sabemos si es simplemente el ojo que registra un dato visible o si debemos pasar a otro plano de significación figurada. Esa duda es la marca poética de Cantiga y de Montañas. Todo es visible, todo es inmediato, percibido por los sentidos. Pero también todo queda vibrando en la palabra, como si demandara un esfuerzo adicional, un impulso hacia otra parte.

Hay que observar que Jiménez se refiere a dos libros de Arango. Es posible que, por tanto, en los dos primeros haya otra noción de "más allá". Y hasta es plausible que la afirmación de Jiménez no pueda referirse sino a Cantiga, porque Montañas parece, al menos en parte, más un homenaje a las concepciones populares. No obstante creo que la acepción más cercana a lo que dice José Manuel en la "Nota" es la que está puesta en un poema de Cantiga, que me obsesiona hace más de veinte años. Para hacerla cercana, transcribo el poema y lo que escribí sobre él en José Manuel Arango. Poética y poesía:

O como dos que hablan después del amor

todavía desnudos

tendidos de espaldas

fumando

y hablan de silencio en silencio

y la voz es sosegada después del amor

y ya sin premura

y entonces ella se incorpora

y pone el codo en la almohada

y pone la mejilla en la palma

y él ve su risa rápida y tranquila

su risa

y el temblor de sus pechos 
"O como": la “escena” es uno de los términos de una comparación. ¿Cuál es el otro?

Las palabras trazan un "cuadro" -el poema es muy "visual"- de una pareja heterosexual (ella, él) en los momentos que suceden a la unión carnal.

El "cuadro" mezcla aquellos hechos que duran con otros que son únicamente momentáneos. Los primeros siete versos hablan de esta duración; los otros seis, de un hecho que podemos llamar puntual dentro de esa duración. Durante los momentos que siguen al encuentro, continúan desnudos, fuman, hablan con sosiego. De repente ella hace algo, algo como su risa, rápido, algo que dura apenas como dura el temblor de sus pechos. Esto es lo dicho, lo explícito.

El poema comienza diciendo "O como". Así pues, lo dicho, lo explícito remite a algo que se esconde más que se muestra. La escena es como... Todo el cuadro es apenas uno de los polos de una comparación. El otro polo está al cuidado del lector... Y sin embargo, forma parte de lo dicho por el poema.

Hay que hacer entonces una lectura filosófica de la obra de Arango. Y hay que abordar el asunto de las relaciones entre filosofía y poesía. Finalmente: creo que el argumento más fuerte está en una afirmación que le entregó Arango en la entrevista concedida a Piedad Bonnett (Que conocí después de haber entrevistado a Arango, por las publicaciones hechas con motivo de su muerte):

Piedad Bonnett: Lo sagrado es muy importante en tu poesía. Tu primer libro está lleno de esa presencia, incluso de la imagen de los dioses. En él encontramos también una dimensión mítica representada en algo que vuelve, que retorna y se manifiesta en las cosas cotidianas, en los hombres más rudos, en los rituales. Cuando tú trabajaste ese tema ¿lo hiciste desde la filosofía o desde unas intuiciones de otra índole?

José Manuel Arango: Ha sido una convicción que siempre me ha acompañado. No creo que los dioses no existan o que estén muertos. Los dioses son ciertas fuerzas, ésas que uno encuentra por todas partes. En un árbol, en un pájaro, en una muchacha, en cada cosa. En los niños, los nietos, por ejemplo, que son como duendes. Es decir, que este mundo está lleno de diosecitos...o de demonios. [...] Tú me preguntas que si eso puede venir de la filosofía. Puede que sí, en parte. Heidegger ha mostrado cómo el monoteísmo fue el comienzo de la muerte de Dios. O de la muerte de lo sagrado.

La respuesta de Arango ("Puede que sí, en parte") obliga a discernir el "pedazo" que le cabe a la filosofía en esta obra. Insisto: exige plantear de manera explícita y detenida el problema de la relación entre filosofía y poesía, como uno de los 
problemas de la lectura filosófica. A mí me llaman la atención los estudios formales de Arango, su pregrado y su posgrado. Parece que la poesía lo tocó con fuerza desde la primaria, a través de su profesor de quinto de primaria. ¿Por qué entonces hace pregrado y posgrado en filosofía? ¿No será que se puede decir de Arango lo que escribió él sobre el médico Williams? ¿Era la filosofía para él una manera de acercarse al mundo? ${ }^{51}$ :

Y qué nexos esenciales van a establecerse entre su profesión y su escritura. Poesía y medicina. No un poeta que es también médico. Ni, mucho menos, un médico que escribe poesía en sus escasas horas libres. La medicina era más su trato con el mundo, su experiencia, la fuente de donde sacaba sus poemas. Lo dijo cada vez que le preguntaron cómo hacía para compaginar dos tareas que parecían tan distintas.

Claro que esto no quiere decir que haya un trasvase inmediato entre la filosofía y la poesía. Detrás de la poesía, siempre enigmática, están las ideas, las creencias de un autor, como el mismo Arango lo dijo. Están "detrás”; pero están. Es verdad que la manera como decía Arango que brotaban sus poemas llena de opacidad su decir, que brota este de una parte oscura y sigue siendo oscuro: “A veces pasa que cuando uno está ocupado en algo, o yendo en un bus por ejemplo, algo le está dando vueltas en la cabeza. Y de pronto se va formando una frase, y la frase se va prolongando... (Babel, entrevista, pág. 24).

\section{...he preferido las preguntas a los dogmas}

El recorrido hecho creo que hace indudable la necesidad de considerar atenta y cuidadosamente las afirmaciones que Arango hace sobre la poesía colombiana. En ellas están planteados problemas como las relaciones entre filosofía y poesía, lenguaje

51 "La poesía de William Carlos Williams", en: Whitman, Dickinson, Williams. Tres poetas norteamericanos, Norma, Bogotá, 1991. 
y poesía, realidad y poesía, razón y poesía. Además de los problemas del poeta, de la poesía, del lector en esta época. Es clara la característica de la lectura hecha desde el mirador de Arango: es filosófica en varios sentidos. Esos problemas forman parte del acervo de la filosofía de todos los tiempos. Pero también es cierto que debe poner bajo la atención lo que se entiende por esta humilde palabra que tiene tantas interpretaciones.

Creo que son claras las bondades de un trabajo como el propuesto. Pero aparentemente tiene limitaciones. El lector es invitado a una lectura filosófica de la poesía colombiana del siglo XX, y se encuentra con la perspectiva ofrecida por un poeta. Por otra parte, nos tenemos que contentar con afirmaciones sueltas, sin desarrollo ni sistemático ni prolongado. Además, si se observan bien esas observaciones sueltas, se trata de algo así como intentos de ubicación personal, aunque sea en el curso de una historia; son como búsquedas de autoexplicación. Finalmente, esa manera de hablar Arango, llena de expresiones que podrían delatar inseguridad: esos tal vez, quizá...

Podría en efecto señalarse críticamente que, si se trata de hacer una lectura de la poesía colombiana del siglo XX, valdría más la pena centrarse en poetas como Fernando Charry Lara o Juan Gustavo Cobo Borda, autores de ensayos y antologías sobre los poetas colombianos. Y si se trata de lecturas filosóficas, ahí están los trabajos de los doctores Gutiérrez Girardot y Danilo Cruz Vélez. Sin embargo, tendremos que decir que lo que sostienen estos personajes es lo que creo que a veces está en juego en ciertas afirmaciones críticas de Arango ${ }^{52}$. Además es lo que hay que

\footnotetext{
52 Gutiérrez Girardot y Cobo toman, por ejemplo, en serio lo de la tradición de la pobreza, noción que creo acuñó el último de los nombrados. Ante este tópico, la afirmación crítica de Arango -También de Charry-. En la entrevista a Babel, afirmó: "Una cultura es un tejido delicado, y no se hace de un momento a otro ni partiendo de cero. Para qué voy a romper con Fernando González si él me dice
} 
revisar y ver si podemos elaborar conceptos, herramientas de trabajo, a partir de los autores mismos, Arango en este caso. $\mathrm{O}$ al menos hacernos transparente lo que queremos decir con esos conceptos. Creo que, en parte, esa es una de las lecciones del periodo de docencia en Salamanca. El profesor Antonio Heredia señaló en su curso algo así como: - "El mayor de los prejuicios es creer que uno no los tiene". Creo que la afirmación se aclara con lo que indica Heidegger, en Ser y tiempo acerca de la situación hermenéutica: no nos acercamos vírgenes a las cosas sino con una precomprensión que es caldo de cultivo para que se metan ideas preconcebidas en nuestras reflexiones. Hablando en efecto del círculo hermenéutico dice Heidegger en esa obra ${ }^{53}$ :

...el cumplimiento de las condiciones fundamentales de toda interpretación exige no desconocer de partida las esenciales condiciones de su realización. Lo decisivo no es salir del círculo sino de entrar en él en forma correcta. Este círculo del comprender no es un circuito en el que gire un género cualquiera de conocimiento sino que es la expresión de la estructura existencial de prioridad del Dasein mismo. No se lo debe rebajar a la condición de un circulus vitiosus, y ni siquiera a la de un círculo vicioso tolerado. En él se encierra una positiva posibilidad de un conocimiento originario, posibilidad que, sin embargo, sólo será asumida de manera auténtica cuando la interpretación haya comprendido que su primera, constante y última tarea consiste en no dejar que el haber previo, la manera previa de ver y la manera de entender previa le sean dados por simples ocurrencias y opiniones populares, sino en asegurarse el carácter científico del tema mediante la elaboración de esa estructura de prioridad a partir de las cosas mismas.

Por otra parte, me parece que lo dicho no es una limitación del trabajo sino de la razón y de nuestra ignorancia humana, que, como me dijo Arango, en el curso de las 24 horas que compartimos en Medellín y en una finca de Copacabana, es oceánica. Mejor dicho, como con mucha gracia decía un profesor mío que murió en 2008: “-Si no es así, ¿entonces cómo?” No es posible evitar la limitación de la perspectiva.

algo, si leo y veo muchas cosas que él me muestra. O con Carrasquilla [Tomás], Epifanio [Mejía]. Son nuestra tradición viva. Si es pobre, porque no son muchos los maestros que tenemos, con mayor razón hay que cuidarla".

53 Traducción, prólogo y notas de Jorge Eduardo Rivera, Editorial Universitaria, Santiago de Chile, 1998, pág. 176. 
Y la limitación de lo que podemos conocer. Arango nos enseña algo en la prosa mostrada en las citas. "Quizá", "Vivimos, me parece”, "Creo que”, "pero tal vez". ¿Son giros que expresan cautela, inseguridad o modestia? En mi libro sobre Arango resolví el "Creo que" con una interpretación insatisfactoria y un poco ligera: modestia. Arango era modesto y tímido. Y cauteloso (Por eso quizá no publicó hasta los 37 años). Pero no son estas características la razón de esta manera de hablar. ¿Cómo se compaginan con la lucidez que hemos ejemplificado? Me parece que tienen que ver con la manera como se muestran al poeta los resultados de su búsqueda, eso que de alguna manera está en el reclamo de San Juan: “Acaba de entregarte ya de vero". Aunque tenga la conciencia de un Valéry o de un Baudelaire, ¿puede el poeta pasar por encima de la opacidad de lo que lo llama, oscuridad en la que con razón insiste María Zambrano?

Si esto podemos decir sobre la poesía, también hay que hablar de la prosa, como la que ejemplifica el texto de la "Nota". Detrás de los notables “creo" "quizá" -como se desprende de su conocimiento de los límites de la razón y de la manifiesta lejanía de la filosofía racionalista- está un intelecto que también es penumbroso, enigmático. Luz sí; pero viviente, es decir penumbrosa, si acudimos a María Zambrano. De ese problema me ocuparé en el siguiente capítulo.

Finalmente, ¿cuáles son los límites de este trabajo? Este trabajo no pretende otra cosa que considerar la versión que da Arango de estos problemas, expuesta tanto en prosas como en el cuerpo mismo de su obra poética. Y a partir de una exposición de lo indicado por él, intentar entrever otros poetas fundamentales. A ello ayudará la consideración de otros puntos de vista. Se necesita la confrontación. Para darle un horizonte adecuado a la mirada de Arango consideraré un conjunto de autores 
colombianos: Silva, Arturo, Mutis, Gaitán Durán. Ya he mencionado las razones para esta escogencia. A las obras de estos notables poetas colombianos se unirá la consideración de trabajos de críticos también poetas: Cobo, Charry, Jiménez, que tienen sobrados méritos como maestros de varias generaciones, y de los filósofos Danilo Cruz Vélez y Rafael Gutiérrez Girardot. Ahora bien, este horizonte de contraste "colombiano" con la voz de Arango se completará con autores exigidos por el desarrollo de poesía colombiana misma: Zambrano, Machado, Paz, Heidegger, Valéry.

El trabajo es limitado. Lo que ahora ofrezco no es otra cosa que una discusión preliminar a la lectura filosófica propiamente dicha. Una lectura filosófica: el tema es vasto y en diversos temas requerirá del trabajo de especialistas. 


\section{Capítulo 2. Poesía y razón}

Uno de los problemas que obliga a reflexionar la obra de José Manuel Arango es el del uso de la razón. Y también nos deja entrever un enfoque del siglo XX en poesía en lo que al tema concierne. Es, creo, indiscutible la necesidad de la razón, como bien al que no se puede renunciar. Pero es preciso especificar a qué tipo de razón nos referimos: no hay una razón a secas, no es ella unívoca.

La primera parte de este capítulo está consagrada a considerar la postura de José Manuel ante la filosofía racionalista. La indagación va, en un primer momento, de la obra de Arango a la de María Zambrano, y se pregunta: ¿Cómo aclara la obra de la pensadora malagueña la del poeta antioqueño? Más precisamente: ¿Cómo se relaciona la crítica al racionalismo filosófico con la búsqueda de lo sagrado en Arango? ¿Cómo se relacionan esta crítica y esta búsqueda en la pensadora malagueña?

Hay una descompensación en mi trato con los dos autores. Es importante señalar esto porque muestra los límites de mi reflexión. He leído a Arango por más de veinte años, seguí paso a paso la aparición de sus libros, he escrito reiteradamente sobre su obra e incluso lo entrevisté antes de su muerte. La cercanía con Zambrano es muy reciente. Me sedujeron inicialmente su estilo -Claro está- y, ante todo, la proximidad aparente de temas con Arango (en particular, lo sagrado). Me atrajeron las relaciones comunes de los dos autores (Unamuno, Lezama, y sobre todo Machado). Pero, hay que decirlo, comienzo apenas a meditar su obra. Por ello, para guiarme en la obra de la pensadora española, me basé, primordialmente, en la primera parte del libro de la danesa Ana Bundgård (Más allá de la filosofía. Sobre el pensamiento filosófico-místico de María Zambrano, Anthropos, Madrid, 2000, 482 págs.), y en dos pequeños textos 
recogidos en el libro Claves de la razón poética: "María Zambrano y la crítica al racionalismo", de Roberto Sánchez Benítez, y "María Zambrano y Cuba: un testimonio", de Cintio Vitier. Las obras de Zambrano aquí consideradas son: El hombre y lo divino, Filosofía y poesía (libro que sigo meditando), el artículo "La reforma del entendimiento" (Senderos, Anthropos, Barcelona, 1986, págs. 73 a 79) y "Razón, poesía e historia", primera parte de Pensamiento y poesía en la vida española, Endymion, Madrid, 1987, págs. 15 a 55.

La segunda parte de este capítulo está consagrada a entrever la posición adoptada en la poesía colombiana del siglo XX ante este asunto. Arango señala donde mirar: hay que ir al nacimiento de la poesía en esta época, a José Asunción Silva y Baldomero Sanín Cano. Señalo también los límites de esta consideración: ciertamente he estado estudiando a Silva siempre, pero no tengo una versión de primera mano de su novela. Tampoco la tengo de la obra de Sanín Cano, cuyos Escritos, publicados por Colcultura hace ya 33 años (1977) leí en algún momento casi en su totalidad. Por eso, me apoyo primordialmente en David Jiménez, Charry Lara e incluso Gutiérrez Girardot, en las obras mencionadas al comienzo del capítulo anterior. La última parte de este capítulo considera lo que pueden ser indicios de un uso de la razón menos dogmático, podríamos decir "más tranquilo".

La exposición en primer lugar mostrará las reservas de Arango ante la filosofía racionalista; en segundo lugar, y con base en el texto "Nota", explorará la conexión entre la poesía, como búsqueda de lo sagrado, y los límites de la razón. Enseguida, se centrará en la "Sinopsis de la piedad", capítulo que abre la segunda parte de El hombre y lo divino. Finalmente irá a Silva y a unos ejemplos. 
¿Qué sentido tiene la exploración hecha en este capítulo? La indagación acerca de los límites de la razón y la crítica al racionalismo no solo es un tema académico de actualidad. Es suficiente considerar algo tan determinante como son hoy los medios de comunicación. Soberbia de pretendidos expertos que no dan cabida a la más mínima duda y que ocultan sentimientos e intereses. Por ser este un tema pertinente socialmente es, debe ser, un asunto académico. Tema del conocimiento y tema de la conducta diaria. Eso es lo que dicen Arango y Zambrano. Adelantemos lo que dice esta última en un pasaje de "Razón, poesía e historia”: “...ese racionalismo esencial que nace de Grecia y conforma la vida europea, al menos, en sus minorías dirigentes. Racionalismo que consiste, ante todo, en buscar la verdad en la razón, en el orden del conocimiento. Y en cuanto a la conducta, en aceptar como motivos las razones".

\section{...mi primera decepción con la filosofía racional}

No es solo deslumbramiento lo que me ha producido la lectura de María Zambrano. La verdad, asombra. Lo cierto es que incluso antes de proponerme el acercamiento de esta pensadora con el poeta colombiano, creo que ella me franqueó observaciones de Arango que para mí eran enigmáticas o en las que no me había detenido. Observaciones que por otra parte pueden ser importantes para apreciar en su justo valor la obra del poeta colombiano, dado que alcanzan hasta el lugar donde actúa la conducta misma, como veremos. Un ejemplo de las últimas es la reserva -o distancia o desconfianza- de Arango ante la filosofía racionalista, que había tomado solo como una especie de anécdota y que aparece reiterada en entrevistas hechas al 
antioqueño, nacido en el Carmen de Viboral. Tal es el caso de lo que dice a la revista Babel ${ }^{54}$ :

Como a los once años, cuando terminé la primaria en El Carmen salí para el Seminario de Medellín. Ahora, el Carmen es casi un barrio de Medellín, pero hace medio siglo era un pueblito que quedaba muy lejos. Para un muchacho que no era rico, la única manera de salir de allá a seguir estudiando era irse para el Seminario. Por otra parte, a uno lo predisponían para eso. Mi mamá rezaba todos los días una oración para que Dios le diera un hijo sacerdote. Claro, el cura era prestigio y poder. En los pueblos de Antioquia y más en los del oriente, prácticamente no había una autoridad civil, el que mandaba era el cura.

Bueno, el Seminario lo marca a uno. De ahí vino por ejemplo la decisión de estudiar filosofía. Por ahí a los 15 o 16 años, en algún curso, me encontré con los cinco argumentos para demostrar la existencia de Dios; yo no sé si por ese tiempo tenía mis dudas sobre Dios. Debió ser, cuando las famosas "cinco vías" de santo Tomás me interesaron tanto. El álgebra había sido como un juego; que haya una X, una incógnita y que por medio de una operación, la incógnita aparezca como si se sacará una paloma de un sombrero. Eso era asombroso. Pero cuando la X es nada menos que Dios... bueno eso es otra cosa, ya no es ningún juego. Decidí que iba a estudiar filosofía. Ahí me apunto, dije. Mucho después encontré que Kant en la Crítica de la razón coge los cinco argumentos de santo Tomás y los demuele uno por uno, demuestra que la existencia de Dios no se puede. Tal vez esa fue mi primera decepción con la filosofía racional.

En estas palabras de Arango llama la atención que la primera decepción con

la filosofía racionalista tuviera como fondo la demostración de la existencia de Dios.

Creo que estos dos temas se mantendrán entrelazados en el pensamiento del profesor

Arango, del poeta Arango, para siempre. En la misma entrevista (págs. 13 y 14),

vuelve aparecer el motivo de la demostración de la existencia de Dios:

Babel: Para un profesor de lógica, el lenguaje es algo preciso. Usted afirma que la poesía es algo irracional, algo que brota de una parte oscura, como un sueño. ¿Qué se hace el profesor de lógica?

J.M.A.: Ahí sigue, supongo. Pero, ¿para qué insistir en eso? Lo de profesor de lógica es una etiqueta, una suerte de estereotipo. Es verdad que durante un tiempo me fascinó la lógica, que es también como el álgebra, parecida a un juego. Tal vez me quedó la intriga desde que vi que la lógica puede aparentemente demostrar a Dios y también que no es posible demostrarlo. Tal vez quería averiguar qué hay ahí. Si se ahonda un poquito en la lógica se encuentra que es también una especie de crítica de la razón. Hay teoremas o metateoremas, que muestran los límites de las formas matemáticas de prueba, que en el fondo son las mismas de la razón. Qué pueden hacer y qué no. Por ejemplo, hasta dónde puede llegar un computador. Así

${ }_{54}$ Bustamante, Víctor, y otros, "Conversatorio con José Manuel Arango. El excesivo pudor", Babel, N 4, Medellín, Diciembre de 1996 - Marzo de 1997, pág. 10. 
se puede demostrar que un computador no puede manejar conjuntos infinitos de cierta especie. Mucho menos se puede esperar que demuestre la existencia de Dios.

Límites de la razón. Distancia de la filosofía racionalista ${ }^{55}$. Decía antes que había lugares referentes a Arango que, pese a lo frecuentados, no se me habían abierto, despejado. Uno de estos está en la entrevista concedida a Piedad Bonnett ${ }^{56}$ :

Piedad Bonnett: Y mientras escribes, José Manuel, ¿isientes el peso del bagaje filosófico?

José Manuel Arango: No, de ninguna manera. Ése no es un peso. Te decía que la filosofía y la poesía a mi manera de ver pueden estar muy unidas. Eso sí, trato de no usar conceptos ni palabras abstractas en un poema. Yo creo que un poema debe nacer de una experiencia personal, no de una idea. Una experiencia alegre o dolorosa pero siempre muy concreta. Que la voz pudiera salir de bien adentro, como la de esos cantantes y esas cantantes de jazz. Es difícil, lo común es que se resulte impostando la voz. Pero bueno, uno trata. Trata de partir de una experiencia, de un momento de esos en los que parece que despierta y que comprende algo. Y como todos tenemos momentos así, entonces la experiencia puede ser compartida.

“...trato de no usar conceptos ni palabras abstractas en un poema. Yo creo

que un poema debe nacer de una experiencia personal, no de una idea". Ya Valéry recordó lo que claramente dijo Mallarmé: “-Mi querido Degas, no se hace poesía con ideas sino con palabras". Aquí Arango, simplemente señala que "trata" de no usar conceptos ni ideas. ¿Eso indica que a veces se "meten" malamente los conceptos y las ideas? Distancia entre filosofía y poesía. Esto lo aclarará un poco más el capítulo que veremos luego. Pero adelantemos -como nos ayuda a decir Zambrano-: la poesía trata de lo "in"-concebible, de lo que no se deja reducir a

${ }^{55}$ El profesor Arango, en julio de 1978 participó, con una ponencia, "La lógica nueva, una crítica de la razón", en un congreso de filosofía que se llevó a cabo en Bogotá. Con celeridad se publicaron las memorias (Actas del III Foro nacional de filosofía, revista Ideas y V alores, Nos. 53, 54, Universidad Nacional de Colombia, Bogotá, 1978, págs. 81 a 86). El último párrafo de la ponencia de Arango dice: "La nueva crítica de la razón no está cerrada. Es ya hora, no obstante, de destacar algunas enseñanzas suyas. Y habría que subrayar, ante todo, contra cualquier racionalismo presuntuoso, pero también contra los diversos irracionalismos en boga, que es la propia razón la que descubre sus limitaciones, y que sólo ella, con sus procedimientos rigurosos, es capaz de probarlas". Ni racionalismo ni irracionalismo. Respeto a la razón.

${ }^{56}$ Bonnett, Piedad, "Entrevista con José Manuel Arango", En: José Manuel Arango, La tierra de nadie del sueño. Poemas póstumos, Ediciones DesHora Intergraf, Medellín, 2002, pág. 61. 
abstracciones. Por otra parte, Arango plantea la unidad de filosofía y poesía, pero no de toda filosofía. La página anterior de la entrevista de Bonnett ${ }^{57}$ :

Piedad Bonnett: Durante toda la vida fuiste docente de filosofía. ¿Crees que para el desarrollo de la vocación literaria fue una buena opción dedicarte a este oficio?

José Manuel Arango: Yo creo que sí, que la filosofía y la poesía tienen una misma raíz. Uno de los filósofos más secos, Aristóteles, dijo que la filosofía venía del asombro, del maravillarse. Y en el origen la filosofía y la poesía eran una misma cosa: los presocráticos eran poetas filósofos. Después hubo un alejamiento, sobre todo en la época racionalista. Ahora se vuelve a los comienzos. Los últimos filósofos, los que de verdad cuentan, vuelven de nuevo a la poesía. Ahí están los ejemplos de Schopenhauer, de Nietzsche, de Heidegger.

Para Arango, filosofía y poesía tienen la misma raíz. Son distintas por lo ya dicho, pero no enjuicia la filosofía en general (Una vez en un poema habla de los "filósofos", pero se refiere a Anaxágoras -Ver "Capítulo 3. Poesía y filosofía"-); como sí lo hace con la filosofía racionalista, de la cual se desmarca: "Los últimos filósofos, los que de verdad cuentan, vuelven de nuevo a la poesía”. La transcripción de la réplica de José Manuel hecha en la nota de pie de página agrega una carácter de esa filosofía racionalista: "sistemática" - Puede uno suponer que un hombre que llamó a sus poemas "fragmentos" tiene que alejarse de lo que implique sistema, y es bueno tener esto en cuenta para reflexionar incluso sobre sus propias prosas-.

\section{Poesía y límites de la razón}

Las afirmaciones de José Manuel Arango sobre los límites de la razón se complementan bastante bien con la segunda parte de la "Nota", ya mencionada. Este es un texto de cuatro párrafos que -confieso- se me ha convertido en una obsesión. Creo que los cuatro párrafos de este "fragmento" constituyen una lección que podría

\footnotetext{
${ }^{57}$ En la página 13 de la entrevista concedida a Babel, hay una afirmación parecida: “... me parece claro que la poesía y la filosofía tienen una misma raíz: el asombro, la maravilla. Los primeros filósofos eran poetas, muchos de ellos escribieron en verso. Después la filosofía se fue separando de la poesía, se hizo más racional y sistemática. Pero recientemente ha vuelto a darse una coincidencia. Por ejemplo, con Nietzsche, Unamuno o Heidegger; ahí están Bruno y Pascal”.
} 
ser estudiada muy largamente, desde diversas perspectivas: el punto de partida del poema, relaciones entre poesía y sociedad y entre lenguaje cotidiano y lenguaje poético, concepto y metáfora, función de la poesía, etc. Nunca necesitó Arango muchas palabras para decir... mucho. Para el propósito de este trabajo basta centrarnos en lo relativo al intertítulo: poesía y límites de la razón. Transcribamos la "Nota" en su totalidad:

Es difícil saber hoy lo que debe ser la poesía. Hubo tiempos en los que su lugar parecía claro. Hasta hace no mucho, en realidad. Los poetas se unían en movimientos y escuelas, se escribían manifiestos. Parecía haber una causa común, aun si se daban corrientes discrepantes y hasta contradictorias. La última vez que esto sucedió fue en los años sesenta, que como se sabe fueron de utopías. Ahora cada quien escribe desde el retraimiento, buscando solo su camino. La aparente riqueza que resulta de la diversidad de voces puede ser también un signo de orfandad.

Quizá el poema nazca de la exploración de una circunstancia compartida, o como respuesta a una experiencia personal, dolorosa o alegre. Unas contadas palabras que serán reflexión, no del intelecto solamente, sino del ser todo de carne y hueso. Detrás de ellas estará por supuesto todo eso que se llama una visión del mundo: convicciones religiosas o políticas, aprendizajes o escarmientos. Desde allí se habla y se valora, tal vez dudando, otras equivocándose. Desde allí se trata de distinguir lo verdadero de lo falso, en la emoción y en la palabra, lo honesto de lo ficticio, o retórico o sentimental.

Pero el poema, más que de una visión del mundo, surgirá de lo que Unamuno llamó un sentimiento de la vida. Está hecho no sólo de enunciados, de afirmaciones y negaciones, sino de los verbos y sustantivos de una lengua que tiene una historia, de palabras que por sus sonoridades y cadencias despiertan ecos y asociaciones, está hecho de imágenes y de ritmos, de rupturas y silencios. Por eso es difícil decir en prosa, herramienta del intelecto, lo que dice o muestra un poema si es verdadero, lo que bregan por decir esos textos fallidos en los que generalmente nos quedamos.

Creo que hay una manera más comprensiva de acercarse a las cosas y a los hombres, y que está justamente en la poesía. Hasta me empeño en no creer que no existan los dioses o que hayan muerto. Es un anacronismo, por supuesto, pero tal vez un anacronismo necesario, en esta hora, para la poesía. Siempre me ha acompañado la convicción de que lo sagrado, lo que Lezama Lima llama sobrenaturaleza, no puede negarse impunemente. Sólo que no es cosa del otro mundo. Son esas fuerzas que uno encuentra por todas partes: en un árbol, en un pájaro, en un niño. Hasta en los pícaros y tahúres y matones que ahora nos acorralan. Tales dijo hace ya siglos que todo está lleno de diosecitos...o de demonios. Yo quisiera, si fuera posible, ser su discípulo en esa especie de politeísmo, o polidemonismo, o pandemonismo. 
El eje del texto - una paginita- está en la afirmación del último párrafo: "Creo que hay una manera más comprensiva de acercarse a las cosas y a los hombres y que está justamente en la poesía”. ¡Cuánta riqueza hay en esta frase! Si la poesía es una manera más comprensiva, entonces es una forma de conocimiento. Ya lo decía en una cita transcrita antes: “... uno trata. Trata de partir de una experiencia, de un momento de esos en los que parece que despierta y que comprende algo". Uno comprende algo. Pero es un conocimiento para la acción, para la conducta del hombre. Es para acercarse a las cosas y a los hombres, para des-alejarlos. La poesía es conocimiento, pero conocimiento para la vida. ¿Sobre qué trata ese conocimiento? Es conocimiento $-\mathrm{y}$ trato- con lo sagrado. Esto lo aclara la frase que viene enseguida: "Siempre me ha acompañado la convicción de que lo sagrado, lo que Lezama Lima llama sobre-naturaleza no puede negarse impunemente. Sólo que no es cosa del otro mundo".

Dejemos para más adelante la pregunta de qué es lo sagrado para Arango ${ }^{58}$. Dejemos también para luego la pregunta de frente a qué manera de conocimiento es la poesía más comprensiva. Tiene esta frase una mirada poco habitual en nuestro medio $^{59}$ sobre la poesía: preocupación por allanar el camino a la relación con las cosas y con los hombres. Por eso dijo en una entrevista que "la poesía enseña a ser... Mejor a no ser". Otra frase poco habitual en una entrevista hecha a un poeta. Y

58 Claro que son muy distintos entre sí los poetas San Juan de la Cruz y Arango. Pero venimos de la misma formación católica - Aunque luego lleguemos a "esta segunda inocencia/ que da el no creer en nada"-, de la misma lengua; y es inevitable encontrar proximidades. En San Juan de la Cruz, como en el primer libro de las Confesiones, todas las cosas están atravesadas por algo ¿más? "Mil gracias derramando/ pasó por estos sotos con presura/ Y yéndolos mirando,/con solo su figura,/vestidos los dejó de su hermosura". Algo que imanta todas las cosas está también en Arango. Uno habla de Dios; el otro de diosecitos. Quizá uno podría llamarlo misterio: hay en cada presencia algo que se recata, pero que destella en la presencia. Desarmando. Impulsando a veneración.

${ }_{59}$ Esto no es ajeno a alguien como el poeta y ensayista mexicano Octavio Paz, como se puede ver en el tratamiento que este da a lo sagrado en El arco y la lira. Paz, un poeta que también interesó a Arango. Recordemos que, de acuerdo con el testimonio de este, incluso lo trabajó como pensador en sus clases en la Universidad de Antioquia. De nuevo nos encontramos con un puente entre la malagueña y el antioqueño. 
que deja ver otras profundidades de la frase que nos ocupa ${ }^{60}$. Es irresistible la tentación de hacer dialogar a Arango con Zambrano. En la frase de la nota de pie de página está una manera de acercarse al mundo que es un abandono, un vaciamiento, dicho en palabras de Zambrano ("renunciar al ego", dice Arango). ¿Se puede seguir haciendo de la misma manera la pregunta de Cruz Vélez citada en el anterior capítulo $^{61}$ : “¿Cómo logra una creación de la subjetividad autosuficiente y autónoma del poeta penetrar en el ser de las cosas y sacarlas a la luz?” (Subrayado mío, LHV). Y también en palabras de ella está el rechazo poético de la consolación (En Arango no hay pretensiones de inmortalidad ni de alma ni de cuerpo). Finalmente la "entrega amorosa a las cosas", el encandilamiento ante la belleza del mundo.

Renuncia al ego, renuncia a una serie de pretensiones, celebración de la vida, como dice Arango a veces, la poesía permite abrirse a "esas fuerzas que uno encuentra por todas partes: en un árbol, en un pájaro, en un niño. Hasta en los pícaros y tahúres y matones que ahora nos acorralan". Sigo tan aturdido como

60 Llegué a entrevistar a Arango después de haberle dado vueltas unos cinco años a esta frase. Desesperado. En la conversación que sostuvimos en noviembre de 2001 tuvimos el siguiente diálogo: "LHVT: En la entrevista que usted concedió al cubano Rodríguez Núñez, usted dijo: "La poesía nos enseña a ser... Mejor, a no ser". Yo vi ahí una conexión con Heidegger.

"JMA: Es posible... Es posible...

"LHVT: ¿Qué querría decir usted con esa frase?

"JMA: Puede ser en el sentido de renunciar al ego y a todas esas cosas y abrirse uno de otra manera (Muy humilde) a las cosas, al mundo, a la belleza del mundo, a los diosecitos... y no tener pretensiones, en primer lugar la gran pretensión de ser inmortal, de que después de esta vida hay un premio que da un Dios. Tal vez vaya como por ese lado".

${ }^{61} \mathrm{El}$ sujeto de la Modernidad tiene pretensiones de posesión. Y eso no sucede en lo fundamental en la creación poética. Dice María Zambrano, en la pág. 108 de su libro Filosofía y poesía: "Y para ello, se mantiene el poeta vacío, en disponibilidad siempre. Su alma viene a parecer un ancho espacio abierto, desierto. Porque hay presencias que no pueden descender en lo que está poblado por otras... Desierto, vacío; porque sólo cuando esa presencia llegue, llegarán con ella todas las demás; sólo con su plenitud y su luz, cobrarán cuerpo y sentido las cosas". Y sigue diciendo, con la presencia permanente de San Juan de la Cruz en sus palabras: "Porque a nada se llega por uno mismo. No sólo no es posible poseerse a sí mismo, sino que tampoco se puede poseer ninguna cosa por pequeña, minúscula que sea su existencia. En cada criatura vulgar está el misterio de su ser y el de la creación entera y, ¿cómo venir a poseerlo? En verdad, que aquél que llegara a penetrar enteramente en la existencia de la más deleznable criatura del mundo, habría penetrado en todo el mundo. Mas eso es imposible, como imposible es el poseerse a sí mismo". 
cuando terminé de escribir mi libro, con ocasión de la elaboración de la ponencia para el Congreso Jalla. Entonces me di cuenta de que, si hay en poesía algo así como una preocupación última desde la que brota el quehacer de un autor, esta podría ser en Arango el asunto de lo sagrado. Preocupación última, fuente... La verdad no me he detenido en esto, en que en la poesía haya algo así como esto... Una manifestación muy cercana a la que hace el texto que comentamos es la que hizo Arango en la entrevista de Bonnett: lo sagrado es una convicción suya de siempre.

Si uno es plenamente consistente con la frase de la "Nota", lo sagrado (ese fondo hermético, ambiguo, arcano) es accesible (¿primordialmente -no únicamente?) a la poesía... porque está allá donde no alcanzan abstracciones ni conceptos... Si uno es consistente, para hacérnoslo cercano no hay otro remedio que experimentarlo en un poema. Pero ¿cuál? Puede ser un poema del Arango maduro (de los libros Cantiga y Montañas). Un poema que tenga como tema la mujer, porque Arango dijo en un ensayo sobre la obra de uno de sus poetas más queridos, el colombiano Rogelio Echavarría ${ }^{62}$ : "Quizá la pasión amorosa sea, en nuestro mundo desangelado, una de las pocas puertas que quedan para acceder a eso que Lezama Lima llama sobrenaturaleza. Aquí no es, sin embargo, un sentimiento religioso, o al menos no lo es de manera ortodoxa". Si se trata entonces de traer un poema de esas características, el elegido puede ser "La furiosa alegría", de Montañas, 1995, último libro -no antología- que pudo disponer él mismo para la publicación ${ }^{63}$ :

\section{Con qué furiosa alegría estalla la rosa,}

62 "Una poesía para nuestro tiempo", En: El transeúnte paso a paso, Selección y prólogo de Juan Gustavo Cobo Borda, Colección "Premio Nacional de Poesía por reconocimiento", Universidad de Antioquia, Medellín, 1999, pág. 163.

${ }_{63}$ Poesía completa, Editorial Universidad de Antioquia, Medellín, 2003, pág. 191. 
sola en la punta de su vara
junto al muro,
y amarilla, jamarilla!,
rodeada de una penumbra malva-

Qué gozo ebrio

hay en el paso

de la desconocida

que cruza el puente

con el viento en la cara,

el pelo en el viento,

y la sonrisa delicadamente feroz-

Al menos desde la auto-interpretación del poeta, lo que palpita en este poema es la vida misma ${ }^{64}$, celebrada con lo que le gustaba tanto del Jorge Guillén de Cántico y de la poesía del médico y poeta William Carlos Williams: el "recio júbilo". La vida, ¿Otro nombre de lo sagrado? La vida es aprehendida acá a través de dos “puertas": la mujer y la naturaleza. Sobre la celebración de esta última podríamos citar muchos poemas. La vida es una de las palabras fundamentales de Arango, una de las palabras que también habría que indagar en Zambrano.

Digamos que la metáfora se teje en silencio, o al menos de una manera discreta con los guiones largos, que hacen del paso de la muchacha una glosa del estallido de la rosa. En silencio, apenas "espejea” la metáfora: si la sonrisa de la muchacha es feroz, el vocablo "estalla" tiene su ferocidad. Pero la vida, lo "otro", es opaca, irreductible a explicitación. Lo inefable apenas se insinúa. Como quizás apenas se

${ }^{64}$ Dice en la publicación Babel, refiriéndose a la Eva del poema "Pensamientos de un viejo", dedicado al pensador Fernando González: "La vida tiene garras, la muchacha es un símbolo de la vida. Fernando González decía que Dios es una muchacha, la muchacha de las muchachas. Una sonrisa de muchacha es lo más bello, pero también es feroz” (pág. 22). 
insinúa lo otro que siempre acompaña la vida: la muerte, otra palabra fundamental de Arango. ¿De acuerdo con nuestra cultura no será ese malva de la penumbra la presencia de la muerte? $\mathrm{Al}$ menos eso dijo en una entrevista el gran poeta coetáneo de Arango, también académico, Giovanni Quessep.

En el uso habitual de la palabra, "comprensiva, comprensivo" significa algo así como un apertura que acepta, que da espacio para la expansión de lo comprendido. Hay en ella un ensanchamiento que recoge al otro. La poesía es una aceptación de las cosas y de los hombres. Tomarlos como "son". Y para lograr esto hay reflexión, pero no del "intelecto solamente sino del ser todo de carne y hueso", ha de haber "sentimiento de la vida". Esta nota "teje" una oposición entre la poesía y la prosa, y entre el hombre de carne y hueso y el hombre solo intelecto. Es verdad que concede algo al intelecto: "es difícil decir en prosa, herramienta del intelecto". Difícil. No imposible. Pero habría que preguntarse a qué tipo de intelecto se refiere Arango. La "Nota" que comentamos es instrumento del intelecto. A diferencia de sus prosas poéticas $^{65}$ no hay aquí una sola metáfora, a excepción de la orfandad del poeta (que a su vez puede ser orfandad universal del hombre que no se abre a lo sagrado -y que en nuestro país rompe y desgarra de manera brutal al hombre y a la naturaleza-). Pero hay algo notable en esta herramienta del intelecto en José Manuel: lo que

${ }^{65}$ Compárese con un fragmento de la prosa poética de "La bailarina sonámbula", un poema sobre la poética de Lezama (Y también de Valéry -este texto se parece mucho a la "Filosofía de la danza", del francés-): "Si la prosa corresponde al caminar llano, la poesía corresponde a la danza. Debe pues empinarse, alzarse un tanto del suelo, levantarse sobre la prosa de vida ordinaria como la bailarina se pone en punta de pies.

"Pero no es un vuelo. La bailarina no vuela. Es casi como si fuera a volar, a despegarse del suelo, pero el gesto es a medias irónico, no trata de engañar, no sugiere ninguna elevación fingida. Así como el baile nace de la marcha, es como un andar tocado por la música y regulado por el ritmo, así la poesía debiera nacer de la vida común, de sus situaciones y experiencias. La bailarina, excepto por la breve duración de un salto, mantiene los pies sobre la tierra”. Poesía completa, Editorial Universidad de Antioquia, Medellín, 2003, pág. 298. 
declara la palabra "Creo" en la frase que nos ha servido de eje al comentario. Lo que declaran otras cautelosas expresiones en la "Nota": "La aparente riqueza que resulta de la diversidad de voces puede ser también un signo de orfandad", “Quizá el poema nazca de la exploración de una circunstancia compartida, o como respuesta a una experiencia personal, dolorosa o alegre". "Puede ser", "quizá", “creo": la opacidad, el misterio se trasladan a lo que Arango conocía más que nadie: la poesía. Su prosa también es opaca. La ignorancia humana es oceánica. Y por eso hay que tomar en serio y pensar la manera en que habla la prosa de Arango. Dice con entera precisión ${ }^{66}$ : "Quizá el poema nazca de la exploración de una circunstancia compartida, o como respuesta a una experiencia personal, dolorosa o alegre". Afirma con plena deliberación: "Creo que hay una manera más comprensiva de acercarse a las cosas y a los hombres". Detrás del "creo" y el "quizá" -como se desprende de su conocimiento de los límites de la razón y de la manifiesta lejanía de la filosofía racionalista- está un intelecto que se sabe penumbroso, enigmático. Luz sí; pero viviente, es decir penumbrosa, si acudimos a María Zambrano.

Pero esta manera de decir puede recibir también luces desde la "metafísica de poeta" de don Antonio Machado. Ana Bundgård ha señalado la importancia de aquella para la forja del pensar poético de Zambrano. En el caso de Arango, creció con Machado como creció con Silva. En el libro de la danesa ${ }^{67}$ se describe de la siguiente manera la metafísica de poeta:

\footnotetext{
${ }^{66}$ No sobra hacer explícito lo referente a la tremenda precisión de Arango. En la versión revisada de su texto "La poesía de José Manuel Arango", David Jiménez agregó una consideración sobre el ensayo de Arango sobre William Carlos Williams, ya citado. El hecho que sea añadido posterior, creo que agrega valor a lo expresado por Jiménez: "Un escritor tan preciso como Arango escribe: 'todo es ahí', no 'todo está ahí'. Esa es la poética que encuentra en Williams y lo fascina” (En: José Manuel Arango, La tierra de nadie del sueño. Poemas póstumos, Ediciones DesHora Intergraf, Medellín, 2002, pág. 132).

${ }^{67}$ Más allá de la filosofía. Sobre el pensamiento filosófico-mistico de María Zambrano, Anthropos, Madrid, 2000, pág. 122.
} 
Machado, por medio de Mairena y sin establecer jerarquías, decía que la metafísica de poeta era una forma peculiar de metafísica, "una metafísica para andar por casa", lo cual, sin embargo, no significa que para él sea la metafísica poética una "metafísica menor": se trata más bien de una forma especial de metafísica en que: "[...] las preguntas radicales guardan aún el estremecimiento de la admiración originaria de que han surgido y las respuestas de que se dispone no gozan todavía del estatuto teórico de las 'ideas', 'sino aquel otro de las creencias' con que cuenta uno, al decir de Ortega, en que se apoya uno para vivir -o quizá y éste era el caso de Machado-, el de las apuestas cordiales cuando no hay respuestas que se mantengan en pie ante el asalto de la duda (Cerezo Galán, Palabra en el tiempo. Poesía y filosofía en Antonio Machado, Gredos, Madrid, 1975, pág. 41)

Mejor así. "Creo": "apuesta cordial..." Claro que la duda está también en la poesía de Arango. Dice David Jiménez al comienzo de "La poesía de José Manuel Arango ${ }^{68 "}$ : “como en Hölderlin, el poeta conserva su función de mediador. Pero es un mediador desconcertado, con más dudas que certezas". Dudas que Jiménez también encuentra en Silva. En efecto, refiriéndose al "Nocturno" ${ }^{69}$ : "El poema de Silva, desde su título, es sólo interrogación y duda. El tono jubiloso del poeta romántico se sustituye por el caviloso y sombrío del modernista".

\section{...isla de luz en medio de las tinieblas}

No está en este pensamiento hacer de El hombre y lo divino el título general de los libros por mí dados a la imprenta, ni de los que están en camino de ella. Más no creo que haya otro que mejor les conviniera. Aunque en verdad, quien esto escribe lo hace desde adentro y no puede ver el resultado desde afuera.

María Zambrano, El hombre y lo divino

68 Obra citada, pág. 97.

69 Antología de la poesía colombiana, "Sobre la presente antología", pág. 19. 
física del Renacimiento, modelo de conocimiento científico. Y este podría ser el resumen de la crítica de la razón hecha desde el punto de vista de su puro funcionamiento.

$\mathrm{Y}$ aquí nos encontramos ante la necesidad de una nueva y más compleja crítica del entendimiento o de la razón humana. Y es la necesidad que se presenta con apariencias de imposibilidad de su cumplimiento, de la penetración de la razón en esas zonas insondables de lo irracional ${ }^{70}$. Necesidad que no brota de una ambición de conocer, de una soberbia del entendimiento, sino muy al contrario de circunstancias pavorosas por las que pasa el hombre $[\ldots]$

María Zambrano, Senderos

Las nueve páginas que conforman el capítulo "Sinopsis de la piedad", en El hombre y lo divino, emplazado en el centro del libro, comienzan con un par de metáforas que dicen la relación entre pensamiento y vida humana: la conciencia es una superficie, la conciencia es una isla de luz en medio de las tinieblas. En efecto la conciencia encubre las formas íntimas de la vida humana; la luz de la conciencia ciega la mirada para las tinieblas de realidad que rodea. El resultado es que el hombre no se siente parte del universo. Como dice en "Razón, poesía, historia" (Pág. 23): "La soberbia llegó con el racionalismo europeo en su forma idealista y muy especialmente con Hegel. Soberbia de la razón es soberbia de la filosofía, es soberbia del hombre que parte en busca del conocimiento y que se cree tenerlo, porque la filosofía busca el todo y el idealista hegeliano cree que lo tiene ya desde el comienzo. No cree estar en un todo, sino poseerlo totalitariamente”. Aquí es fuerte el ataque de Zambrano al racionalismo, especialmente de ese que además de ser racionalismo es soberbio. La última frase es de las quedan resonando en la memoria: "No cree estar en un todo, sino poseerlo totalitariamente" (Me recuerda a Arango: "Sabe/ que una noche los

\footnotetext{
${ }^{70}$ En Filosofía y poesía, pone María Zambrano una nota bastante diciente, en el curso de su "diálogo" con Platón: "Tal vez toda la crisis actual por la que pasa la cultura occidental no sea en esencia sino la crisis de esta idea platónica hecha creencia en la conciencia europea, en los momentos más felices de la vida de Europa. La naturaleza humana es la razón. Es lo que hoy muchos hombres se rebelan a aceptar”. (Fondo de Cultura Económica, México, 1993 (1939), pág. 52.
} 
ojos con que mira/ el girasol serán el girasol//que la lengua que canta es también parte/ del todo").

Está claro dónde estuvo el desvío del racionalismo europeo. Para el propósito de este texto, para ver la conexión entre racionalismo y encubrimiento de lo sagrado, uno tiene que preguntarse cómo presenta Zambrano lo que está debajo, encubierto, u oculto a fuerza de luz. Y debe indagar cómo es el conocimiento del hombre al que se le retira lo sagrado, el individualista de corazón "que ha perdido de vista la unidad última del universo, donde sólo ve cosas inanimadas o materia informe que en gracia a su razón [su propia y personal razón, dice poco antes, en la pág. 191 de El hombre y lo divino] llegan a tener un orden y un sentido". Voy a ceñirme a este par de preguntas y dejo de lado la consecuencia, que para Zambrano es "pavorosa": el empobrecimiento de la realidad que es también empobrecimiento del hombre. El empobrecimiento de la realidad está en el hecho de quedarse solo con la luz y perder de vista las tinieblas; el empobrecimiento del hombre está en la reducción de sus vínculos con la realidad a la conciencia: “Al reducirse el conocimiento a la razón solamente, se redujo también eso tan sagrado que es el contacto inicial del hombre con la realidad a un modo único: el de la conciencia”,

Las maneras como Zambrano nombra eso que está encubierto por el racionalismo, en El hombre y lo divino son abundantes: "algo más hondo que las creencias mismas, las formas íntimas de la vida humana", "la inserción del hombre

${ }^{71}$ El hombre y lo divino, F.C.E., México, 1993 (1955). Según Vitier, este libro pudo haber tenido origen en Cuba, hacia 1940. Esto quiere decir que la concepción de los textos comentados aquí es del primer momento del exilio. Filosofia y poesía y Pensamiento y poesía en la vida española son de 1939. 
como criatura viva en el universo", "la raíz metafísica [de la vida humana] -que ha quedado invisible o que aparece sólo parcialmente". Cuando acude a la reflexión sobre la historia de la filosofía precisa lo encubierto como la historia, el no ser, el tiempo $^{72}$ :

A pesar del descubrimiento del ser y del pensar la vida humana durante todos esos siglos había estado enclavada en la inmensa realidad de diversas maneras. El pensar es actualidad y apenas puede comprender el pasado, el pensar capta el ser y deja fuera lo que es a medias, lo que es y no es, lo que no puede entrar dentro del principio de contradicción.

Una página más adelante vuelve a insistir sobre lo dicho, y agrega la muerte ${ }^{73}$ :

Y no solo los semiseres y el tiempo, sino también la muerte, que no siendo vida ocurre en la vida; la muerte y los muertos, es decir, todo lo que de un modo u otro está en otro plano que la vida lúcida de la conciencia; lo que no se sabe, "lo otro". La vida humana, apetencia inextinguible de unidad, está rodeada de alteridad, lindando con "lo otro". Y eso idéntico que el hombre cree ser en los momentos en que la inteligencia le saca fuera de la vida por su simultaneidad y su actualidad, tiene que tratar con "lo otro". No somos sólo sujeto de conocimiento, un punto de identidad...

Debo confesar que estas pocas páginas tienen una densidad que hacen que todavía se me escape mucha sustancia. (Por otra parte, casi que todo texto requiere no solo paciencia para demorarse en él sino que además tiene pliegues que hacen que no sea del todo una metáfora aquella del libro infinito de Borges, en el Libro de arena. Cada uno de los grandes pensadores tiene una riqueza que se va abriendo con el tiempo, de tal manera que corremos el riesgo de entender una cosa cuando ya olvidamos en qué parte la leímos e incluso quién la dijo). Creo que se me escapa todavía lo central de esta noción de "no ser", aunque creo tiene que ver con la posibilidad que explora el poeta, con los ensueños ${ }^{74}$ (otra palabra fundamental de

\footnotetext{
72 Ibídem, págs. 195, 196.

${ }^{73}$ En el ensayo sobre Arturo, dice Arango: "Cierto que es imposible imaginar o pensar la propia muerte, porque el yo que trata de pensarla sigue ahí presente. Pero ello no implica que no podamos experimentar nuestra muerte de un modo más decisivo que el del mero pensamiento. El púber asiste a su propia muerte" (“Aurelio Arturo y la poesía esencial”, en: Aurelio Arturo. Morada al sury otros poemas, Norma, Bogotá, 1992, pág., 51). ¿Pensamiento e imaginación versus experiencia?

74 Para ver aquello de lo que se ocupa el poeta es preciso meditar algo que está puesto en el primer capítulo de Filosofía y poesía (Págs. 17 y 18): "El poeta no renunciaba ni apenas buscaba, porque tenía.
} 
Arango que la enriquece con diversos matices: entresueño, duermevela, trasueño) que se tejen en él. Más clara es la manera como plantea Zambrano el desvío de la filosofía occidental, el desvío ocurrido con la victoria de Parménides sobre Heráclito. Y la repercusión del pensamiento filosófico en la transformación del mundo ${ }^{75}$ :

Transformar el mundo no es otra cosa que modificar eso último para lo que no tenemos nombre, la inserción del hombre en el universo, la situación con referencia a todas las especies de la realidad, de lo que es y de lo que no es. Para el "saber absoluto" todo es "ser", como para todo idealismo y racionalismo. Ortega, en su crítica del idealismo, lo hacía notar bien, oponiendo "lo que hay" a lo que es. Lo cual puede significar que en lo "que hay", fuera del ser o sin haber llegado al ser, existen varias especies de realidad. Aristóteles dijo "el ser se dice de muchas maneras" y ahora tendríamos que decir que la realidad -la que no está en el ser- tiene muchas maneras de entrar en contacto con el hombre, pues no podemos decir que se diga de muchas maneras, ya que el decir solo se refiere al ser. Solamente puede decirse lo que en alguna forma es.

La filosofía racionalista se quedó con el ser, dice Zambrano. La pregunta que inauguró la filosofía es la pregunta por el ser. En El hombre y lo divino, la pensadora la plantea en los términos siguientes: “¿Qué son las cosas?”, formulación en la que resuena el ser. Y al lado del ser, la filosofía se quedó con el pensar, un pensar que, como pensar del ser, es actualidad. Triunfo de Parménides: "Lo mismo es a la vez pensar y ser". Por esto la afirmación anterior consistente en que lo oculto en la hipertrofia de la conciencia racionalista o en la soberbia del espíritu absoluto es el no ser, el tiempo -la historia- y la muerte (El espíritu absoluto, para Zambrano, reivindica la historia, pero sometida a la razón: “...lo originalmente histórico, [...] quedaba en Hegel encubierto, totalmente absorbido bajo la razón”). Y también predominio del sujeto: "El hombre se tornaba en simple soporte del conocimiento racional, con todo lo que eso conlleva de extraordinario, pero la realidad en torno se

Tenía por lo pronto lo que ante sí, ante sus ojos, oídos y tacto, aparecía; tenía lo que miraba y escuchaba, lo que tocaba, pero también lo que aparecía en sus sueños, y sus propios fantasmas interiores mezclados en tal forma con los otros, con los que vagaban fuera, que juntos formaban un mundo abierto donde todo era posible. Los límites se alteraban de tal modo que acababa por no haberlos". Extraño cortejo: lo percibido, lo soñado, fantasmas interiores y fantasmas exteriores... Arango y Quessep hablan de sus fantasmas, de unos fantasmas que rondaban fuera.

75 El hombre y lo divino, pág. 195. 
iba estrechando a su compás; a medida que 'el sujeto' se ampliaba, diríase que absorbiendo las funciones que el alma desempeñaba antes, la realidad se empequeñecía ${ }^{76}$ ". Subjetivismo desbordado. (¿Venganza de Protágoras a quien Fernando González por boca de Arango interpela: "Porque el hombre, animal saltarín, animal triste,/¿de qué puede ser medida?”)

Si la realidad se empequeñece, el hombre, por su parte, está mutilado. El hombre del racionalismo no tiene cuerpo ${ }^{77}$. Y no tiene entrañas, sede del padecer y de la esperanza $^{78}$ :

Si el intelecto es vida en acto, actualidad pura e impasibilidad, eso otro de la vida humana es lo contrario: pasividad, padecer en toda forma, sentir el instante que gota a gota pasa, sentir inapelablemente el transcurrir que es la vida, padecer sin tregua por el hecho simple de estar vivo, que no puede reducirse a razón. Sentir la multiplicidad, la discordancia, lo heterogéneo aun en sí mismo -si es que hay "mismo" en este estrato de la vida-, sentir lo que no se dice, estar condenado al silencio.

Solo indiqué antes las consecuencias del racionalismo: mutilación de la realidad, mutilación del hombre. Dejo ahora que sea Arango quien diga algo acerca del particular. Comencemos por esto último: mutilación del hombre.

Volví a publicar la ponencia de Jalla en la revista Escarabeo (“¿Una búsqueda de lo sagrado? Aproximación a la poética de José Manuel Arango”, págs. 71 a 75). Ahí me preguntaba por qué la poesía es para él una manera más comprensiva de acercarse a las cosas y a los hombres. Me apoyé en un poema de Arango, extraño porque es el único poema en donde José Manuel parece francamente indignado, donde está,

\footnotetext{
${ }^{76}$ Ibídem, pág. 192.

77 Ibídem, pág. 191: "Quedaba la conciencia en su claridad lunar aislada hasta el (Sic:) propio cuerpo, donde por no se sabe qué azarosa contingencia venía a estar insertada".

78 Ibídem, pág. 196.
} 
como dicen en España, "cabreado". Por lo general es sumamente meditativo. El poema es "Hay gentes que llegan pisando duro":

\author{
Hay gentes que llegan pisando duro \\ que gritan y ordenan \\ que se sienten en este mundo como en su casa
}

Gentes que todo lo consideran suyo
que quiebran y arrancan
que ni siquiera agradecen el aire
Y no les duele un hueso no dudan
ni sienten un temor van erguidos
y hasta se tutean con la muerte
Yo no sé francamente cómo hacen
cómo no entienden

Decía, pues, en la pág. 74 de la revista: “¿Qué es lo que no comprenden los que llegan pisando duro? Sin duda no entienden algo que reitera José Manuel en su obra: no entienden que somos mortales. Pero esto no daría pie a tanta indignación. Además de ser adultos normales, es decir que han olvidado, estos seguramente irrespetan a la muerte: la tutean. Y él hasta el final trata a la "Flaca" con "Fineza", como titula un poema de los "Póstumos": "Y decirle, cuando llegue, a la Flaca:/ Adelante, señora, Bien sea venida”. Estas gentes ni siquiera agradecen el aire. Se sienten aquí como en su casa y no entienden que aquí no hay que 'fincar'. Pienso que José Manuel trata con consideración a esos que han olvidado y a los cuales la poesía tiene que recordarles, avivarles el seso como dice Jorge Manrique en esos versos que Arango hace resonar en el ensayo 'Aurelio Arturo y la poesía esencial', publicado por 
Norma en 1992. Los que indignan a José Manuel son esos que pisotean lo sagrado que está en todas partes”.

Es una gran mutilación ser tan desagradecido, tan inconsciente. Pero la realidad resulta también mutilada. En primer lugar la realidad de la muerte, la cual es un tema fundamental de Arango, recorrido desde los primeros libros. Coincidiendo con otros que ya han puesto de presente la degradación de la muerte hoy, dice Jiménez sobre este tema en Arango: "La poesía [de Montañas] se esfuerza por revivir la muerte, por despojarla de las capas de sucesiva abstracción, indiferencia y banalidad con que la cultura contemporánea ha ido recubriéndola" ${ }^{\text {"79 }}$. Y así como critica la comprensión contemporánea de la muerte, José Manuel se lanza contra los actos que muestran el aborrecimiento de la vida, las torturas de seres humanos, por ejemplo. Por eso no ha de extrañar una frase tan aparentemente fuerte como esta de Jiménez: "Cantiga representa, en conjunto, una tremenda reflexión, muy mediada por la dicción poética, sobre el momento histórico que vivimos. Puede afirmarse, casi sin paradoja, que José Manuel Arango escribe la poesía más pura y, al mismo tiempo, una de las más fuertemente comprometidas con una posición moral y política, en el contexto de la literatura colombiana actual" ${ }^{\prime 80}$.

\section{Silva es el padre joven muerto}

Arango remite a Silva. Recordemos la frase ya citada en el anterior capítulo: "Ya sabemos que él es el iniciador de la poesía moderna en Colombia, el que la puso en este tiempo. Es como el padre muerto joven de todos nosotros. Todavía vivimos, me

\footnotetext{
${ }^{79}$ En: La tierra de nadie del sueño. Poemas póstumos, pág. 148.

${ }^{80}$ Ibídem, pág. 137.
} 
parece, en la problemática que él planteó. La pregunta por la técnica y el progreso, la pregunta por la posibilidad de la poesía”. Remitir a Silva es proyectar a finales del siglo XIX. Y es remitirnos también a Baldomero Sanín Cano, el cual inicia la crítica moderna en 1888, con el artículo "Núñez, poeta”. En realidad el momento al que Arango invita es de confrontación: Núñez y Caro vs. Silva y Sanín Cano (Por lo que se ve hoy, ganaron los primeros). ¿Qué papel cumplieron los dos últimos personajes? ¿Qué rasgos intelectuales presenta Silva? Y en particular, ¿cuál es su posición frente a la razón?

Arango señala que en Silva están las preguntas por la técnica y el progreso y por la posibilidad de la poesía. Que es un autor moderno. Modernidad estética, sobre la cual dice el profesor Ramón Pérez Mantilla: "Hay además una modernidad estética o cultural, opuesta a la modernidad en su sentido más habitual o clásico, que identificamos con los ideales de la Ilustración: con el culto desmesurado a la razón y su fe ingenua en las bendiciones de la ciencia y de la técnica, con el progreso, en una palabra $^{81}$. Ya esto nos indica algún cambio en el uso de la razón.

¿Cuál fue el papel de Sanín y Silva? Dice Jiménez del primero: “Él y Silva descubrieron, para quienes tenían la voluntad de ser modernos en el país finisecular, los más suculentos filones de la literatura moderna: la poesía simbolista francesa y alemana, el esteticismo inglés, la novela rusa y francesa, la filosofía de Nietzsche, la crítica de Taine y de Brandes" ${ }^{\prime 2}$. Si había alguna duda de mi parte acerca de quién introdujo el pensamiento de Nietzsche en el país, creo que esta afirmación es

${ }^{81}$ Ramón Pérez Mantilla, "Nietzsche y Heidegger, filósofos postmodernos en la interpretación de Vattimo", en: El trabajo filosófico de hoy en el continente (Memorias de XIII Congreso Interamericano de Filosofía, Universidad de los Andes, Bogotá 4 a 9 de julio de 1994, págs. 1064 a 1069), Editor Carlos B. Gutiérrez A., Sociedad Interamericana de Filosofía, Sociedad Colombiana de Filosofía, Editorial ABC Ltda., Bogotá, 1995, 1196 págs.

${ }^{82}$ Historia de la crítica literaria en Colombia. Siglos XIX y XX, pág. 121. 
contundente: fue Silva, quien se lo presentó a Sanín. ¿Los poetas y los críticos son quienes introducen un pensador que debieran haber introducido los filósofos? Claro que la filosofía en Colombia por la época estaba en manos de las comunidades religiosas. Y Nietzsche no era aceptado entonces como filósofo por la comunidad académica internacional ${ }^{83}$.

Ahora bien, ¿qué rasgos intelectuales tenía el autor Silva? Mi admiración por el libro de Jiménez que acabo de citar creo que empezó con el texto que transcribiré a continuación ${ }^{84}$. Pienso que es excusable la larga cita:

En los antípodas de Caro, con su resuelta sumisión a dogmas y verdades eternas, su negativa a cualquier forma de autonomía literaria y su inflexible partidismo político, José Asunción Silva vendría a representar en la literatura colombiana la más libre de las figuras, la menos arraigada en tradiciones o verdades generales, la más flexible y oscilante. En otras palabras, para bien o para mal, la más moderna. En Silva parece quebrarse la armoniosa disposición de los saberes y la posibilidad de encontrar una clave única para su desciframiento. De sobremesa, al mismo tiempo una deficiente novela y un admirable ensayo de reflexión crítica sobre la cultura moderna es el testimonio más desgarrado de lo que significa la modernidad para un escritor latinoamericano. Todo lo que temía Caro y a lo que intentaba oponer el dique de sus creencias religiosas, se da en Silva con esa apariencia de enfermedad espiritual que es propia de la transición a lo moderno en el arte. Curiosidad sin límites, escepticismo, relativización de todos los valores. Absolutización de la experiencia como fuente de la única verdad posible: lo subjetivo. Silva escribió sólo cinco artículos críticos, sin excesiva importancia, pero su novela está llena de momentos ensayísticos en los que, a través de la sensibilidad y las crisis del protagonista, se va filtrando una fina evaluación de la literatura colombiana e hispanoamericana. Sin embargo, Silva cuenta aún más como autor moderno que incorpora la crítica dentro del propio proceso creativo, a la manera de Baudelaire.

83 A propósito de la recepción de Nietzsche, señalaba en 1969 Ramón Pérez M., en la "Presentación" del número de la revista Eco dedicado a Nietzsche, dirigido y presentado por él: “...la clara conciencia que se ha cobrado que su pensamiento, cumplidos ciento veinticinco años de su nacimiento y casi setenta de su muerte, se halla todavía intacto, en posesión de todos sus enigmas. Situación debida en buena parte al hecho de que la filosofía académica alemana se hubiera resbalado con su torpe profundidad en la luz de sus aforismos, negándole el título de filósofo y creyendo ultrajarlo con el de poeta. De esta suerte se ignoró al filósofo en aras del esteta, del sicólogo y del crítico de la cultura. Solo recientemente ha sido puesta de relieve la extrema importancia de su pensamiento filosófico, cuyo rigor equipara Heidegger al de Aristóteles, exigiendo para la comprensión del Zaratustra, el que su lectura sea hecha en unión con la de Las investigaciones sobre la esencia de la libertad humana de Schelling, La fenomenología del espíritu de Hegel y La monadología de Leibniz. El resultado de todo esto ha sido que, como decía no hace mucho Henry Birault, "el sentido propio, el orden lógico y aun simplemente cronológico de los conceptos fundamentales de su filosofía, se halla todavía en la obscuridad" (Eco. Revista de la cultura de occidente, Nos. 113-115, Bogotá, 310 págs.)

${ }^{84}$ Ibídem, págs. 16, 17. 
Podría decirse que en la fluctuación entre los dos polos representados por Silva y Caro avanza la literatura colombiana. En el campo de la crítica, la línea de Caro se perpetúa en Gómez Restrepo y llega hasta Rafael Maya; la de Silva en Eduardo Castillo, hasta Fernando Charry Lara, al menos en cuanto este último encuentra, como Silva, la cuestión crítica ya suscitada por su propia obra poética.

Este fragmento dice muchas cosas. Sin olvidar que el propósito es detenerse en lo que tiene que ver con el uso de la razón, vale la pena detenerse en algunas de ellas. "Sumisión a dogmas": Arango dice que en sus clases prefirió siempre las preguntas a los dogmas. Por supuesto que él está de acuerdo con la autonomía del arte. Lo dijo en la entrevista con el cubano Rodríguez Núñez. El vínculo entre ideología y poesía es “'dañado y punible ayuntamiento' como dicen con tanta gracia los abogados” y por supuesto que "la poesía no tiene otra finalidad que ella misma": "la poesía es eficaz", no útil. Ideas: "El discurso nace de la situación, es una reflexión sobre ella. Y Williams dice, es uno de los axiomas de su estética, que la idea debe estar siempre en las cosas". Arango está inserto en una tradición que viene de Silva.

Hay expresiones de esta cita que todavía me guardan su secreto. "En Silva parece quebrarse la armoniosa disposición de los saberes y la posibilidad de encontrar una clave única para su desciframiento". Dejando de lado la primera oración, que todavía no entiendo, ¿qué significa eso de "quebrarse la posibilidad de encontrar una clave única”? ¿Es lo que pasa en el ensayo de Jiménez sobre "La poesía de José Manuel Arango" cuando dice que su interpretación es provisional y nada estable, como son provisionales las búsquedas y soluciones que ha ido encontrando José Manuel? (Y aquí ya estamos en el uso de la razón, una razón que encuentra sus límites). Finalmente: "Absolutización de la experiencia como fuente de la única verdad posible: lo subjetivo". La interpretación de Jiménez, que, como puede notarse, hace pensar, reitera la palabra experiencia, experiencia como fuente de la verdad subjetiva. ¿Qué significa esto? El asunto de la crítica a la razón está ligado a la discusión sobre 
el asunto de la verdad. Las verdades de Caro están ligadas a ciertas tradiciones históricas y costumbres sociales que vienen de la Colonia, el catolicismo en el aspecto del dogma, la comunidad y la institución, la legislación española y el derecho romano, la lengua castellana y los modelos literarios de las literaturas clásicas y la española. Gramática, catolicismo, nacionalismo. Y frente a ello: lo que llama Jiménez lo subjetivo. Y cielo vacío, cosmopolitismo, iniciativa de las palabras, es decir dejar que los poemas se hagan en uno y luego salgan, como repite Arango a Silva.

¿Y Sanín Cano? "Ni política ni religión ni moral son instancias superiores que legitimen o justifiquen el arte. Son esferas independientes, cada una con su propia legalidad. [...] Sanín Cano desenmascara en los versos de Núñez, precisamente, un contenido que proviene de la filosofía pero que con anterioridad había sido convertido en lugar común para poder llegar con él a un público amplio, conmoviéndolo con la supuesta profundidad de los temas y de los conceptos. [...] Sanín Cano asegura en una nota de pie de página que prefiere la duda expresada sinceramente y con brío por un joven poeta, a la metafísica de segunda mano con que el supuesto poeta filósofo amasa silogismos rimados 'como quien aploma una tapia o cuadra un cercado" ${ }^{\prime 2}$.

Otra vez aparece la duda, en Sanín, pero con cierto acento negativo. No la duda asumida cuando se sabe que la ignorancia es oceánica. Y ante todo queda la pregunta por la verdad. Aquí hice notar que Jiménez dice que la fuente de la verdad es la subjetividad. Al final de su texto sobre la poesía de Arango habla de "verdad de la experiencia”. De ello me ocuparé en el "Capítulo IV. Poesía y experiencia”.

85 En: Miguel Antonio Caro y la cultura de su época - Rubén Sierra, editor, Universidad Nacional de Colombia, Sede Bogotá, 2002, págs. 252-253. 


\section{Unos ejemplos}

Deliberar sobre el tipo de textos de escribimos. Porque la tendencia a hacerlo de manera inercial es grande. Autores como estos pueden ser maestros cuando no queremos escribir de manera inercial, cuando queremos pensar un poco en lo que hacemos.

Me agradan mucho los textos de Charry y de Jiménez. La cercanía con los textos, la ponderación, hacen que incluso a veces se les quiebren los preconcebidos, creo yo. Le pasa a Jiménez. Le pasa a Charry. Traen conceptos de la Ilustración, pero el cuidado extremo, el respeto a los textos que trabajan, en el forcejeo, hacen que despunte otra manera de concebir. Pongo ahora un ejemplo de Charry, hablando de Mutis. Veamos ${ }^{86}$ :

No se añadiría un juicio nuevo si se dijese que la poesía de Mutis está notoriamente gobernada por la riqueza de su imaginación, lo cual no explica del todo, en la generalidad misma con que se expresa, el sentido y proyección que la animan. El mundo de sus fantasmas, el húsar o Maqroll el Gaviero, entre ellos, al tiempo que decididamente se inclina a los poderes de la invención no descarta, de otro lado, un examen de la condición y del destino humanos y una añorante aproximación a la tierra que sirve de fondo a su aventura. [...] La atmósfera de las tierras bajas es en Mutis obsesiva: sus cálidos mediodías en plazas entregadas al bochorno y a los insectos, su naturaleza siempre desmesurada, sus ruidosas lluvias nocturnas oídas y recordadas en la soledad de los aposentos. Los sueños de esta poesía están así íntimamente entrelazados con la visión de un paisaje y de unos hombres que a cada instante son los nuestros. (Subrayado LHV)

¿Es inevitable que, al hablar de poesía, se hable de imaginación? ¿Más precisamente, que las facultades que moviliza la poesía sean imaginación y fantasía? Así pareciera, pero lo importante es que la imaginación se le revela insuficiente a Charry para hablar de la poesía de Mutis, una poesía que sin pensar mucho uno calificaría de "imaginativa". Al menos en parte. Tiene que hablar de que esta poesía

86 Poesía y poetas colombianos, Procultura, Bogotá, 1985, pág. 125. 
es también "examen de la condición y el destino humanos" jamás habla Arango de imaginación. Si le gusta Mutis es "sobre todo" por lo que encuentra Charry: el apego a la tierra. Lo que le gustaba de Arturo -“Tan de aquí, tan nuestro"- son sus raíces). Parentesco, quizá, en la "reflexión sobre lo que somos". ¿Más que imaginación, reflexión sobre lo que somos?: Silva buscaba una poesía en la época de la técnica y el progreso, en la época en la que la poesía se había convertido en una enfermedad. No imaginación sino sentimiento de la vida.

Que me percatara de ello fue posible por el estudio de la relación entre poesía y pensamiento en Heidegger. De una manera muy precisa, el profesor Carlos B. Gutiérrez A, de la Universidad de los Andes y de la Nacional, en el texto "Filosofía y poesía. Vecindad como cercanía y diferencia”, (Ideas y Valores. Revista colombiana de filosofía, Universidad Nacional de Colombia, Departamento de Filosofía, N 95 , agosto de 1994, págs. 29 a 40), dice así:

De la determinación esencial de la filosofía hasta comienzos del siglo XX forma parte su autocomprensión como ciencia, como ciencia primera y de fundamentación absoluta, cuyos agentes son la razón y el entendimiento. Tal la tradición que a partir de Platón y de Aristóteles pasa por Descartes, Kant, Fichte y Hegel, hasta llegar a Husserl. Como ciencia suprema de la razón y el entendimiento, la filosofía se deslinda tajantemente de la poesía, cuyo ejercicio se sitúa en la imaginación o fantasía, es decir, en una facultad espiritual diferente (Negrillas LHV).

¿Eso de que la poesía sea cosa de la imaginación no será un prejuicio que se puede caer en una comprobación detenida? ¿O tendremos que decir que la poesía no es solo imaginación? ¿En unos casos sí y en otros no? Lo cierto es que la interpretación de Heidegger citada por Gutiérrez A. en el mencionado texto (pág. 34) es la siguiente: "El poeta aprende a renunciar a la opinión que hasta ahora ha tenido

\footnotetext{
${ }^{87}$ Dice Carmen Ruiz Barrionuevo: "Es al final de este poema ["Una palabra", LHV] donde Mutis concentra el vértice desde el que emerge la poesía, una poesía nacida de las carencias, de la percepción existencial de la fragilidad humana -Subr. LHV-" ("Introducción. Summa de Maqroll: la poesía de Álvaro Mutis”, en: Summa de Maqroll, el Gaviero. Poesía, 1948-1997, Pág. 34).
} 
de la relación entre la cosa y la palabra. El poeta entendía su poetizar como logro de su facultad de imaginación poética. Se trataba en el poetizar, según creía, de traer los productos de la imaginación a la fuente del habla, confiando en hallar siempre el ropaje estético adecuado a ellos”.

Mantengo al menos como sospecha la inadecuación entre los conceptos manejados en interpretaciones muy serias, que uno duda en discutir. ¿Por qué Arango no usa la palabra imaginación? Sí dice imagen, claro, pero el sueño piensa en imágenes, como dice el Nacimiento de la tragedia.

Otro ejemplo, me parece de honestidad, es el de Cobo Borda. En el "Post-facio a la segunda edición", de su Historia de la poesía colombiana. Siglo XX. De José Asunción Silva a Raúl Gómez Jattin (pág. 24), dice:

Quizá en otra espiral de los tiempos, otras escrituras, aquí no contempladas, y otros poetas, me seduzcan e inciten a compartir sus secretos. Por ahora son estos algunos de los poetas colombianos que me acompañaron. Aquellos cuyos libros tiene uno claramente ordenados en la biblioteca de su casa: Silva, Valencia, Barba, Luis Carlos López, León de Greiff, Rafael Maya, Jorge Rojas, Eduardo Carranza, Fernando Charry Lara, Álvaro Mutis, Jorge Gaitán Durán, Eduardo Cote Lamus, Jaime Jaramillo Escobar, Mario Rivero, Giovanni Quessep, José Manuel Arango...

Esta elección, tan respetable y arbitraria como cualquier otra, sólo busca acentuar el carácter placentero de toda lectura...

Muy cauteloso, como se ve. Pero ¿por qué "arbitraria"? ¿Prejuicios de la democracia? Me gusta que no intente como los políticos del día hablar en un nosotros sospechoso; pero tomarse el trabajo de hacer libros y de argumentar hacen que este trabajo sea todo lo que se quiera menos arbitrario.

Ahora bien, la relación entre poesía y pensamiento, o -para hablar en los términos de Arango-, entre idea y experiencia, es difícil. O la consideración corriente 
le concede poco al pensamiento o no le concede nada. Lo más común es esto. Se piensa que un poeta es alguien incapaz de hacer una regla de tres simple ${ }^{88}$. La práctica de la poesía en Colombia en el siglo veinte, por otra parte, muestra poetas en los que el discurso toma un lugar tal que perjudica la poesía misma. Cobo Borda y Jiménez ponen el caso de Gaitán Durán. El primero, por ejemplo, señala" : "En Gaitán Durán, por primera vez en la poesía colombiana, el cuerpo habla y se desnuda. Es, claro, un cuerpo intelectual que se apoya en Sade y Bataille para proclamar su libertad y su repudio al 'infierno social-patria o clase' -para citar sus propias palabras en el Diario. 'El poema es acto erótico' dice Gaitán, y a renglón seguido se pregunta: ¿Cómo transformar en dato la vibración irrepetible del orgasmo? Sus poemas de Amantes lo intentan y también, quizás con mayor brillo "Sé que estoy vivo". Pero si bien su lenguaje llega a ser suntuoso y de gran firmeza, hay un afán racionalista que congela estos resplandores”. Como ya dije, Jiménez también critica a Gaitán Durán.

88 En el ensayo "Poesía y pensamiento abstracto" (En: Teoría poética y estética, Visor, Madrid, 1990, pág.71), Paul Valéry plantea el problema de esta relación de la siguiente manera: "Con frecuencia se opone la idea de Poesía a la de Pensamiento, en particular de 'Pensamiento abstracto'. Se dice 'Poesía y pensamiento abstracto' como se dice el Bien y el Mal, el Vicio y la Virtud, lo Caliente y lo Frío. La mayoría cree, sin otra reflexión, que los análisis y el trabajo del intelecto, los esfuerzos de voluntad y de precisión en los que se compromete el espíritu, no concuerdan con esa ingenuidad de origen, esa superabundancia de expresiones, esa gracia y esa fantasía que distinguen a la poesía, y que hacen reconocerla desde sus primeras palabras. Si se encuentra profundidad en un poeta, tal profundidad parece de una naturaleza muy distinta a la de un filósofo o un sabio. Algunos llegan a pensar que incluso la meditación sobre su arte, el rigor del razonamiento aplicado a la cultura de las rosas, sólo pueden perder a un poeta, puesto que el principal y más encantador objeto de su deseo ha de ser el de comunicar la impresión de un estado naciente (y felizmente naciente) de emoción creadora, que, mediante la virtud de la sorpresa y el placer, pueda sustraer indefinidamente el poema a toda reflexión crítica ulterior.

Es posible que esta opinión contenga una parte de verdad, aunque su simplicidad me haga sospechar que es de origen escolar".

Y concluye su examen de la siguiente manera (págs. 98 y 99): "Pero todo poeta verdadero es necesariamente un crítico de primer orden. Para no figurárselo, es necesario no concebir en absoluto lo que es el trabajo de la mente, esa lucha contra la desigualdad de los momentos, el azar de las asociaciones, los desfallecimientos de la atención, los entretenimientos exteriores. La mente es terriblemente variable, engañosa y engañándose, fértil en problemas insolubles y en soluciones ilusorias. ¿Cómo saldría una obra notable de ese caos, si ese caos que contiene todo no contuviera también algunas oportunidades serias de conocerse a sí mismo y de elegir en sí lo que merece ser retirado del instante mismo y cuidadosamente empleado? No es todo. Todo verdadero poeta es bastante más capaz de lo que en general se sabe, de razonamiento justo y de pensamiento abstracto" [Subrayados LHV].

${ }^{89}$ Historia de la poesía colombiana, pág. 51. 
Como critica a Valencia ${ }^{90}$. Hablando de los camellos de este: “...los camellos son símbolo del artista que lleva a cuestas lo sagrado, así como la llanura lo es del mundo en su esterilidad espiritual. El simbolismo se petrifica, de esta manera, en un esquema racional y el poema se restringue a un discurso versificado que contiene en sí todas las aclaraciones necesarias para comprender su significado, de manera que éste se erija en único y excluyente. El auténtico símbolo, por el contrario, es ambiguo, polivalente, en perpetua metamorfosis. Como sucede con el poema “...?...”, de Silva. Es pura sugerencia, no sentido lógico que excluya cualquier otra interpretación”.

El tema que nos ha ocupado es siempre actual. ¡Qué duda puede caber acerca de su importancia! Veamos. Dicho en las palabras escuetas de Arango, es relación con las cosas y con los hombres $-\mathrm{y}$ agreguemos: con ese otro desconocido que somos nosotros mismos. Dicho con la urgencia de alguien que acaba de exiliarse, al final de la Guerra Civil Española, en plena víspera de la segunda guerra mundial, con urgencia apasionada $-\mathrm{y}$ afortunada por el poder de lo que transmite-: "formas íntimas de la vida humana", "inserción última del hombre en el universo”. ¿Puede haber tema más actual, más cotidiano? No creo. Y hasta creo que es universal, porque el encuentro diario con los noticieros muestra que no sabemos estar con los demás y que tampoco podemos estar con nosotros mismos. El tema del que nos ocupamos es tema de quienes se han ocupado de la suerte de la humanidad. Ocupado y preocupado.

Llama la atención la convergencia de la preocupación entre María Zambrano (1904-1991) y José Manuel Arango (1937-2002). Llama también la atención la

90 Antología de la poesía colombiana, pág. 25. 
concordancia de la mirada: la razón, considerada como intelecto a secas, es enjuiciada porque mutila la realidad y mutila al hombre. El desarrollo de los dos textos considerados es distinto. Arango describe desde su comprensión de la poesía y de su quehacer y preocupación de poeta. Como se aprecia en aquellas ocasiones en las que habla como filósofo, era capaz de hablar con extrema precisión filosófica y con claridad de docente. Pero su quehacer fundamental era la poesía. No sigue el camino de Machado, no crea apócrifos para decir en prosa filosófica la metafísica de poeta. Escribe ensayos (breve y espléndido, ha dicho un crítico de al menos de uno de ellos) sobre los poetas que interesan a su propia obra; traduce autores con quienes tiene afinidades $^{91}$; y sobre todo hace solo su camino de poeta, en estas épocas en las que "No hay camino", como paladea en un poema Arango. Zambrano aparece preocupada por esclarecer la raíz metafísica de la existencia. Hace el diálogo con la filosofía griega, busca los orígenes de la civilización greco-cristiana, precisamente para desmarcarse: hay que tener clara la historia para no repetir los errores graves que cometemos los seres humanos cuando nos olvidamos del pasado. Su trabajo es el de la pensadora que escribe en una prosa cuajada de metáforas que quedan vibrando en el pensamiento.

${ }^{1}$ En la primera parte de la "Nota" de La sombra de la mano en el muro dice algo sobre los poetas norteamericanos que encontró en los Estados Unidos a fines de los sesenta: "En los años sesenta hice una maestría en literatura y filosofía en la pequeña universidad estadounidense de West Virginia, donde enseñé español para costearme los estudios. Era el tiempo de la guerra de Vietnam, de la desobediencia hippy, de la agitación contestataria en las universidades. Era sobre todo un tiempo de auge y florecimiento de la poesía norteamericana. Más que el movimiento beat, me atrajo otra corriente menos ruidosa: la que podríamos llamar neoimaginistas porque reconocía por maestros a Pound, a Wallace Stevens, a William Carlos Williams. Los neoimaginistas admiraban y traducían a los grandes poetas españoles e hispanoamericanos del siglo, los mismos en los que uno se había nutrido desde la adolescencia: Machado, Vallejo, Juan Ramón, Neruda. De hecho, una de las antologías más conocidas en los Estados Unidos por aquella época tenía por título Naked Poetry, un título que se apoyaba en un verso de Juan Ramón Jiménez. Estas transfusiones -más que traducciones- son seguramente fecundas. La poesía donante es transformada y asimilada y el resultado es un diálogo enriquecedor. En las últimas décadas, me parece, la poesía hispanoamericana ha recibido a su vez un influjo benéfico de norteamericana", en: La sombra de la mano en el muro. Antología, Palimpsesto, Sevilla, España, 2002, págs. 6,7. 
¿Sorpresa por la convergencia en la preocupación y en la mirada? Sí y no. Es verdad que José Manuel Arango no la menciona en ninguna parte, como sí lo hace el poeta colombiano Giovanni Quessep, quien incluso colocó alguna frase de Zambrano de epígrafe en un libro de versos ${ }^{92}$. Pero creo que hay muchos puentes entre los dos. Machado, por supuesto, que para la autora del ya citado Más allá de la filosofía es el inspirador de la razón poética. En la nota que hemos trabajado están Unamuno y Lezama. Y sobre todo está un estado de comunión que crea la lengua española: nuestros son los grandes poetas españoles, y quizá cierto espíritu incluso en esta época de predominio de tantos usos de origen gringo. Acabo de ojear una antología de poesía de Quessep. Ahí están versos de Machado, Quevedo, San Juan, al lado de autores de otras lenguas y de los nuestros de siempre, en este caso José Asunción Silva.

Todavía estoy sorprendido con el encuentro con Silva. Es difícil agregar nada a la tremenda contemporaneidad de este bogotano muerto antes de cumplir 31 años. Por otra parte, si es claro que hacer la lectura juiciosa de Arango obliga a involucrar la filosofía, también es cierto que es preciso que la mirada sea histórica. Nada le quita a su capacidad hacer parte de una tradición sobre la cual tenía un saber tan claro.

Finalmente, una lectura filosófica tendrá que ocuparse de pensar el uso de conceptos como interioridad, subjetividad, imaginación. La obra de Arango por lo

\footnotetext{
92 En el libro de Piedad Bonnett, Imaginación y oficio. Conversación con seis poetas colombianos, Colección Celeste, Editorial Universidad de Antioquia, Medellín, abril de 2003, pág. 50, esta poetisa colombiana le pregunta a Quessep: ¿Y también te interesa la filosofía? - Bueno, yo estudié Filosofía y letras, pero realmente no me he dedicado a la filosofía. De vez en cuando leo libros filosóficos, de Platón, por ejemplo... En mi época de estudiante leí mucha filosofía, leí todo Unamuno, todo, todo. Yo era unamuniano a morir. Ahora leo mucho a María Zambrano. Me gusta cómo escribe, porque tiene un estilo muy bello. Y me interesa bastante lo que dice de las relaciones entre filosofía y poesía...
} 
menos deja el interrogante de su legitimidad. Y creo que también la obra de Zambrano. 


\section{Capítulo 3. Poesía y filosofía}

Si uno quiere hacer una lectura completa de la poesía de José Manuel Arango, es necesario plantear explícitamente la relación entre filosofía y poesía. E igual sucede si quiere considerar la poesía colombiana del siglo XX. La afirmación doble parece excesiva. Procuraré argumentarla a lo largo de este capítulo.

Advierto de entrada que los que para mí son poemas más logrados de Arango (el "Himno al sol" de los Poemas póstumos y "Pensamientos de un viejo", sobre el pensador antioqueño Fernando González), tienen que ver con la filosofía. Ya me referiré al primero de estos poemas. En este último presenta al personaje de tal manera que es irresistible la tentación de sentir uno que está ante un autorretrato de Arango. En la primera página de mi libro sobre Arango, en el cual hice una lectura muy detenida de este poema, escribí:

Arango nos acerca en el poema a un enamorado de las palabras, a un buscador del silencio, a un hombre meditativo vuelto hacia su tierra con los cinco sentidos, y que ante todo mira y remira: una mirada pensativa. Estos rasgos, que aplica a González, se le pueden aplicar a él (No sólo se parecen él y González en la mirada metafísica, como Arango mismo dijo en la entrevista que concedió a Babel). Y una de esas características, espirituales digamos, da una primera justificación, porque leer a Arango es entrar en una "larga meditación" -como la que él destaca ${ }^{93}$ en González:

3

Dos rasgos sobre todo resaltan en el rostro magro:

la quijada saliente

y los ojos de una inquietud atenta.

Van del sarcasmo a la inocencia, al gozo, a la duda.

Ya estudian burlones a la gente que pasa.

Ya se fijan, mansos y lúcidos, en las palomas.

4

${ }_{93}$ José Manuel Arango, Poesía completa, Editorial Universidad de Antioquia, Medellín, 2003, págs. 266, 267. 
Y todo lo que ven es asunto de su lento monólogo,

todo casa en la larga meditación que lo ocupa.

En ella cada cosa tiene un lugar y un sentido.

Es una pregunta, una señal.

5

Por ejemplo, esa muchacha que cruza. Una bella negra

cuyo paso está hecho del ritmo que marca un tambor lejano.

Lo oye en sueños o ebria. Camina, danza.

Es Eva, de catorce años y medio.

\section{Poesía y filosofía en Arango}

Como José Manuel Arango fue un gran poeta y tenía formación académica de filósofo y como además terminó jubilándose de profesor de lógica de la Universidad de Antioquia, la pregunta obligada en las entrevistas era la siguiente (Conozco cinco entrevistas, una de las cuales hice yo mismo poco antes de la muerte del poeta).

Babel: Hay una afirmación de Salvatore Quasimodo acerca de que los poetas son enemigos naturales de los filósofos.

J.M.A.: Todo lo contrario; me parece claro que la poesía y la filosofía tienen una misma raíz: el asombro, la maravilla. Los primeros filósofos eran poetas, muchos de ellos escribieron en verso. Después la filosofía se fue separando de la poesía, se hizo más racional y sistemática. Pero recientemente ha vuelto a darse una coincidencia. Por ejemplo, con Nietzsche, Unamuno o Heidegger; ahí están Bruno y Pascal.

La respuesta es desconcertante. Y deja intuir una presencia muy fuerte de la poesía en la obra de Arango. Me parece, por otra parte, que el tenor mismo de la pregunta deja ver una opinión muy extendida: uno se resiste a creer que puedan estar unidas filosofía y poesía.

Dejo por ahora esto de lado, y me concentro en la lista de filósofos que proporciona Arango. A la cual habría que agregar a Schopenhauer, al cual cita en 
otras entrevistas. Y al mismo González. E incluso al budismo zen. Me detengo en esto porque la lista es larga, y mi ignorancia grande. Luego tendré que escoger -en este planteamiento del problema de la relación entre filosofía y poesía- uno de estos pensadores. Ahora bien, la lectura filosófica propiamente dicha tendrá que sopesarlos, creo, a todos. ¿Por qué? Uno de los mejores poemas de Arango es sobre González, hizo cursos en la Universidad de Antioquia sobre él, en Colombia se habla de un Nietzsche de Fernando González. Además, ya cité a Roca sobre el particular: "Pero José Manuel Arango tiene también otra línea de su poesía que se mueve en una preocupación por su entorno, por definir las cosas de sus Montañas, de su región, en la cual encuentro también una cercanía con la dicción de un orbe más filosófico, aunque a veces poético, que tenía Fernando González, que tenía inclusive Epifanio Mejía" (subrayado, LHVT).

Unamuno. Arango lo menciona unas pocas veces, pero es muy significativa la manera de hacerlo. En la cita de la lista, es uno de los filósofos "que de verdad cuentan", según la respuesta que le dio a Piedad Bonnett ("Los últimos filósofos, los que de verdad cuentan, vuelven de nuevo a la poesía".) En la "Nota", ya mencionada también, está citado, creo, dos veces (En un texto de cuatro párrafos; con la sola compañía de otro filósofo: Tales de Mileto; en un ensayo elaborado poco antes de morir: última palabra). La primera cita es explícita:

Pero el poema, más que de una visión del mundo, surgirá de lo que Unamuno llamó un sentimiento de la vida.

Sospecho que esta otra afirmación también tiene que ver con Unamuno. Y tiene que ver nada más y nada menos que con la "raíz" de la poesía de Arango:

Quizá el poema nazca de la exploración de una circunstancia compartida, o como respuesta a una experiencia personal, dolorosa o alegre. Unas contadas 
palabras que serán reflexión, no del intelecto solamente, sino del ser todo de carne y hueso (subrayado, LHVT).

Ahora bien, intentar abarcar en este trabajo a estos pensadores, está fuera de mis alcances. Por ello me situaré en Martin Heidegger. ¿La razón? Además de que las breves indicaciones de Arango necesitan un horizonte de resonancia, en cierto modo hay una línea de continuidad Schopenhauer-Nietzsche-Heidegger. Por otra parte, puede ser un caso de relación muy rico, está ligado a una convicción de Arango y a unos poetas fundamentales para éste. De ninguna manera intento hacer ver a Arango como un heideggeriano: Arango era Arango, hasta donde uno puede ser el que uno es. Por lo que veremos más adelante, y es un rasgo que comparte con Silva, trataba de pensar con su cabeza y con su cuerpo. Nada de dogmas.

\section{El cambio en la autocomprensión de la filosofía}

Volvamos a la respuesta de Arango en la entrevista con Babel: "Los primeros filósofos eran poetas, muchos de ellos escribieron en verso. Después la filosofía se fue separando de la poesía, se hizo más racional y sistemática. Pero recientemente ha vuelto a darse una coincidencia". "Los últimos filósofos vuelven a la poesía", dice en otra entrevista. Filosofía y poesía están unidas. Está también la razón de la cercanía: lo dice Arango con una palabra que para mí sigue guardando un secreto. Dice que filosofía y poesía tienen la misma "raíz", y que esa "raíz" es un sentimiento: el asombro $^{94}$. Esto es bien molesto: la "raíz" de algo que uno presume tan racional, de algo que estruja tanto el cerebro como lo hace la filosofía, es un sentimiento. Pero aquí sí que no hay nada raro: esto que Aristóteles repite en la Metafísica lo dice Platón en Teetetes. Dice también José Manuel que se alejaron filosofía y poesía durante la

94 Como otras palabras de Arango, esta me la abre, me la franquea un poco Zambrano. Dice ella al comienzo de Filosofía y poesía: "¿Qué raíz tienen en nosotros pensamiento y poesía? No queremos de momento definirlas, sino hallar la necesidad, la extrema necesidad que vienen a colmar las dos formas de la palabra". (Pág. 15) 
época racionalista. Y pone algunos ejemplos de casos de cercanía entre filosofía y poesía: Nietzsche, Heidegger, Miguel de Unamuno, Giordano Bruno y Blas Pascal, Schopenhauer. Como lo dejan claro otras entrevistas, para Arango estaba claro que están unidas, incluso "muy unidas" pero que hay diferencias entre filosofía y poesía. Lo decía a su manera: "Eso sí, trato de no usar conceptos ni palabras abstractas en un poema”.

Esto que indica de una manera tan nítida el poeta colombiano, lo dice así, en relación con Heidegger y nuestro tema, el filósofo Carlos B. Gutiérrez A ${ }^{95}$ :

De la determinación esencial de la filosofía hasta comienzos del siglo XX forma parte su autocomprensión como ciencia, como ciencia primera y de fundamentación absoluta, cuyos agentes son la razón y el entendimiento. Tal la tradición que a partir de Platón y de Aristóteles pasa por Descartes, Kant, Fichte y Hegel, hasta llegar a

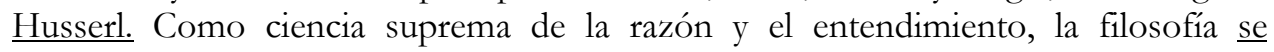
deslinda tajantemente de la poesía, cuyo ejercicio se sitúa en la imaginación o fantasía, es decir, en una facultad espiritual diferente.

El vuelco que se anuncia en los giros "pensar y poetizar", "poetizar y pensar" es un vuelco en esa autocomprensión de la filosofía y en la separación rigurosa de filosofía y poesía que ella entrañaba, una vez que se entrevén las insuficiencias de la determinación filosófica tradicional de lo que es el ser humano. La filosofía se ve ahora en esencial cercanía a la poesía, cercanía que al mismo tiempo encierra una diferencia esencial. Y es precisamente para hacerle justicia a semejante relación sobre la base de una nueva determinación del ser del hombre que Heidegger no habla más de filosofía y poesía sino de "pensar y poetizar". A la relación así planteada Heidegger termina llamándola "vecindad". (Subrayados, LHV)

Lo que Arango enuncia de una manera a la vez sencilla y precisa, lo dice Carlos B. Gutiérrez A. de manera más técnica: dice en primer lugar que la filosofía se autocomprendió como ciencia, ciencia primera y de fundamentación absoluta, en un recorrido de 23 siglos: de Platón a Husserl. Señala así mismo que, para esta manera de comprenderse a sí misma la filosofía, los “agentes”, las facultades que moviliza, son razón y entendimiento. Y que comprendiéndose de este modo la filosofía "se deslinda tajantemente de la poesía" que procede mediante la imaginación o fantasía.

95 "Filosofía y poesía. Vecindad como cercanía y diferencia", Ideas y Valores. Revista colombiana de filosofía, Universidad Nacional de Colombia, Departamento de Filosofía, º 95, agosto de 1994, págs. 29 a 40. 
Finalmente, que el pensamiento de Heidegger es una transformación en la manera de comprenderse la filosofía y su relación con la poesía.

Hay un par de cosas que no dice aquí Arango y que dice Carlos B. Gutiérrez A. Primera: para la comprensión tradicional, "los agentes de la filosofía son la razón y el entendimiento"; los de la poesía son la "imaginación o fantasía" (Arango no lo dice aquí, pero es notable el hecho que en su obra no usa para nada la palabra imaginación. Este es tema de otro capítulo). Segunda: El cambio en la manera de concebir la relación entre filosofía y poesía se funda en una nueva manera de determinar el ser del hombre (Lo que no dice Arango aquí explícitamente está sin duda en la base de la comprensión de esa "reflexión sobre lo que somos" que es la poesía, "reflexión del ser todo de carne y hueso").

Tendremos que detenernos más en este cambio en la autocomprensión de la filosofía, tendremos que mostrar sus implicaciones temáticas y metodológicas. Pero ya lo dicho merece reflexión. Porque es raro que a uno le digan que filosofía y poesía están unidas. Basta recordar lo que dice el filósofo Rubén Sierra Mejía en el texto “La filosofía y la literatura" ${ }^{96}$, publicado en Golpe de dados: las posturas extremas de Platón

96 "Con cortesía y con todos los honores, Platón propone expulsar al poeta del Estado cuya organización diseña en la República. Si llegare a presentarse a las puertas de nuestra ciudad, nos recomienda despedirlo, 'tras derramar mirra sobre su cabeza y hacerla coronar con cintillas de lana'. Esta actitud ha sido profusamente comentada como para que nos detengamos en ella. El propio Platón nos asegura que no es suya, que es antigua, y que no es él a quien debemos acusar de duro y torpe: 'la desavenencia entre la filosofía y la poesía es de antigua data', asevera. Y en el siglo XX, un poeta, Paul Valéry, parece recordarnos que esa mutua antipatía aún persiste: 'la filosofía, afirma, si se le quitan las cosas imprecisas y las ya refutadas, se reduce entonces a cinco o seis problemas, precisos en apariencia, negables a voluntad, reducibles siempre a querellas lingüísticas y cuya solución depende de la manera de escribirlos'. Y en otro lugar, confiesa: '...leo mal y con fastidio a los filósofos'. Pero lo desconcertante de los testimonios citados, es que sus autores, Platón y Valéry, parecieran descalificar sus propios juicios con sus particulares maneras de pensar. Pocos filósofos han logrado, como lo logró el autor de El banquete, una conjunción tan perfecta entre el concepto y la metáfora, el raciocinio y la imaginación. Y el poeta francés, no sólo por sus ensayos sino también por sus poemas y sus célebres diálogos socráticos, se ha convertido en una fuente de pensamiento para el filósofo, que busca en ella nutrirse de ideas que le ayuden a dar claridad sobre los problemas estéticos y específicamente del conocimiento de la obra de arte”. Golpe de dados. Revista de poesía, N CXXVI, Volumen XXI, Bogotá, noviembre-diciembre de 1993, pág. 101, 102. 
y de Valéry. O lo que dice María Zambrano en el comienzo del libro maravilloso Filosofía y poesia ${ }^{97}$. Los dos con unas posturas muy matizadas, nada simplificadoras. Y basta considerar las entrevistas hechas a Arango. Era reiterada la pregunta de si la poesía no constituía una carga para el poeta: Juzguen ustedes las preguntas:

- Hay una afirmación de Salvatore Quasimodo acerca de que los poetas son enemigos naturales de los filósofos.

-Y mientras escribes, José Manuel, ¿sientes el peso del bagaje filosófico?

Las preguntas indican la extrañeza. Las respuestas de José Manuel eran básicamente las mismas, expresadas con extrema sencillez: "filosofía y poesía pueden estar muy unidas pero procuro no usar conceptos ni palabras abstractas en un poema", repetía. Y agregaba algo así como: "Yo creo que un poema debe nacer de una experiencia personal no de una idea". Esta es una de esas frases que merece una reflexión atenta. Y lo haré en otro capítulo de esta tesis. Observó aunque sea de pasada el uso de la palabra experiencia por Arango, como también lo hace Gutiérrez A en la frase que enuncia la relación entre filosofía y poesía en Heidegger desde los años treinta: "El filósofo, como lo ilustra la obra de Heidegger, se vuelve primero a las experiencias poéticas, buscando en ellas pistas o señas para la experiencia pensante". Y ello no solo para "nutrirse de ideas que le ayuden a dar claridad sobre los problemas estéticos y específicamente del conocimiento de la obra de arte”, como

\footnotetext{
97 "No tratamos de hacer aquí la historia de estas alternativas, aunque ya sería de gran necesidad, sobre todo estudiando sus íntimas conexiones con el resto de fenómenos que imprimen carácter a una época. Antes de acometer tal empresa vale más esclarecer el fondo del dramático conflicto que motiva tales cambios; vale más atender a la lucha que existe entre filosofía y poesía y definir un poco los términos del conflicto en que un ser necesitado de ambas se debate. Vale, sí, la pena manifestar la razón de la doble necesidad irrenunciable de poesía y pensamiento y el horizonte que se vislumbra como salida del conflicto. Horizonte que de no ser una alucinación nacida de una singular avidez, de un obstinado amor que sueña una reconciliación más allá de la disparidad actual, sería sencillamente la salida a un mundo nuevo de vida y conocimiento" (Fondo de Cultura Económica, Madrid, 1996 (1939), pág. 14. Ella traza en su libro un cuadro inicial de aguda discrepancia, la "antigua desavenencia" a la que se refiere Platón en República, seguido de algunas reconciliaciones, pero predomina la discordia. En el penúltimo capítulo se expresa un deseo: “¿No será posible que algún día afortunado la poesía recoja todo lo que la filosofía sabe, todo lo que aprendió en su alejamiento y en su duda, para fijar lúcidamente y para todos su sueño?” (Pág. 99).
} 
lo dice Rubén Sierra en la nota de pie de página. Es para la experiencia pensante toda. Experiencia...Experiencia...

Fui a Medellín en noviembre de 2001 a entrevistar a José Manuel Arango. Desde que hablamos por teléfono para concertar la cita, le dije que quería saber acerca de su relación con Heidegger. Transcribo lo que me dijo, en una entrevista que hasta ahora está inédita

Luis Hernando Vargas Torres: Ya le comenté que me interesa la relación suya con Martin Heidegger: ¿Cómo está Heidegger ahí, en su obra poética?

José Manuel Arango: Como profesor de filosofía nunca trabajé a Heidegger, pero siempre me interesó. Como le decía, yo traté de "meterle el diente" a Ser y tiempo. Y lo leí, lo releí, durante un tiempo más o menos largo. Realmente el Heidegger que más me ha interesado a mí es el de Caminos del bosque (Sendas perdidas). Por ejemplo, su visión de Nietzsche, de la muerte de Dios, de la relación de la muerte de Dios con el superhombre (Con lo que según Heidegger es el superhombre para Nietzsche). Me interesa esa actitud ante la vida que es capaz de vivir sin dioses... o sin Dios (Mejor que sin dioses, sin Dios), porque es afrontar la vida frente a la muerte, "ser-para-la-muerte", como dice Heidegger, sin pensar en otra vida, inmortal. Lo cual no implica que uno niegue los dioses. Tal vez ellos huyen por los monotéísmos...

Ahora están los tres monoteísmos, ahí agarrados, tratando de destruir el mundo. Ahí tenemos a Bush, a los fundamentalistas musulmanes y a los judíos. Son las tres religiones monoteístas las que están haciendo el mundo invivible; porque los pueblos politeístas, como los romanos, nunca fueron fanáticos, aceptaban otros dioses y les era posible tener diosecitos por todas partes y para todo.

Para volver a Heidegger: su crítica del monoteísmo, cuando Heidegger dice que la "desdivinización" o el "desendiosamiento" empezó con el monoteísmo, ha sido importante para mí. Por otra parte, su visión de la poesía y cómo Heidegger lo lleva a uno a Hölderlin, lo lleva a Trakl, lo lleva a Rilke (a cierto Rilke: el de las Elegias y de los Sonetos a Orfeo). Sí, yo sé que Heidegger es un filósofo muy difícil, que uno nunca puede llegar a decir que entendió; pero le toma ciertas cosas que le llegan a uno, que lo marcan y ya están en uno, de alguna manera...

Con Schopenhauer, con Nietzsche, con Heidegger tuve una relación muy personal, que nunca toqué en mis cursos de filosofía. Mis cursos de filosofía eran sobre el lenguaje, pero desde otra perspectiva. 
Retengamos algo de lo que dice el poeta acá. Nos indica sus lecturas de Heidegger y su manera de leerlo ${ }^{98}$. Dice que leyó Ser y tiempo. Y Sendas perdidas, Holzwege, libro traducido de nuevo en los noventas como Caminos del bosque. Por otra parte menciona algunos de los poetas sobre los cuales trabaja Martin Heidegger: Hölderlin, Rilke, Trakl (Al cual el mismo Arango tradujo en algún momento).

(Para quien estudia la obra de Arango, estos tres poetas, Hölderlin, Rilke, Trakl, son vitales: no se trata en manera alguna de una mención erudita de Arango sino de poetas de los cuales se podría decir que son "influencias" en la obra de Arango; e incluso algo mejor, porque es la manera de referirse al tema José Manuel: personajes con los cuales tiene afinidades, parentesco. Por otra parte, el asunto de la crítica al monoteísmo en la obra de José Manuel es tan importante que cuando Piedad Bonnett le pregunta de si el tema de lo sagrado, fundamental en la obra de Arango, lo ha trabajado desde la filosofía, este responde: "Tú me preguntas que si eso puede venir de la filosofía. Puede que sí, en parte. Heidegger, por ejemplo, ha mostrado cómo el monoteísmo fue el comienzo de la muerte de Dios. O de la muerte de lo sagrado, de la desdivinización").

\footnotetext{
${ }^{98} \mathrm{Me}$ parece que es muy difícil pronunciar un juicio general sobre la obra de Heidegger. Arango dice una de esas razones: dificultad. La otra radica en el carácter voluminoso de esta obra, cuya recopilación completa debe de andar por los 100 volúmenes. Estos dos caracteres aparecen en la reseña del profesor Ramón Pérez sobre el libro Heidegger, de Steiner, publicada en 1985 en la Revista de la Universidad Nacional de Colombia: "Publicado originalmente en inglés, aparece ahora en una excelente versión castellana este trabajo de Steiner sobre el filósofo de la Selva Negra. Steiner empieza enumerando en el prólogo las razones por las que hacer una breve introducción al pensamiento de Heidegger, es decir, escribir el libro que ha escrito, es una tarea llena de dificultades y, en últimas, prácticamente imposible. Nos habla en primer lugar del carácter descomunal de la producción intelectual de Heidegger, cuyas obras completas en curso de publicación alcanzarán un total de sesenta volúmenes, la mayoría de los cuales versan sobre cursos y trabajos no publicados en vida, o sea, inéditos, lo que según Steiner nos impide, hoy por hoy, pronunciar un juicio definitivo sobre muchos aspectos controvertidos de su vida y de su pensamiento. A ello habría que agregar -y Steiner así lo hace- el hecho de que Heidegger es, sin lugar a dudas, uno de los pensadores más complejos y difíciles de la historia de la filosofía, del que muchas veces ni siquiera sabemos qué es lo que está diciendo". Comparto plenamente la manera tranquila de leerlo Arango: tomar algunas cosas indiscutibles, y hacer juicios sobre tal o cual tema, sobre tal o cual texto.
} 
Como podemos apreciar, Arango nos ayuda a indicar la bibliografía, en Heidegger, del tema que nos ocupa. Ahora bien, si ponemos, como hicimos antes, a conversar a Arango con Carlos B. Gutiérrez A., y con G. Vattimo, en este punto, vemos, además de la coincidencia en Ser y tiempo:

Ya en 1934, al ocuparse Heidegger por primera vez en una lección del tema de la esencia del lenguaje (Sobre la lógica como indagación de la esencia del lenguaje), se va moviendo la determinación del pensar a partir de su cercanía al poetizar hacia el centro de la reflexión heideggeriana. En el semestre siguiente (1934-1935), dio él su primera lección sobre Hölderlin bajo el título de Los himnos 'Germania' y 'El Rin' de Hölderlin. Es muy diciente que la última lección en Friburgo en el verano de 1944 se llamara Introducción a la filosofía. Pensar y poetizar. Para Heidegger era ya completamente evidente que el camino hacia el pensar genuino pasara por la reflexión sobre la relación esencial de pensar y poetizar ${ }^{99}$ (Subrayado LHV).

Además de los títulos mencionados, Carlos B. Gutiérrez A menciona la conferencia de 1955 en Cerisy-la-Salle “¿Qué es eso de la filosofía?”, ¿Qué significa pensar", el libro Interpretaciones sobre la poesía de Hölderlin, y se centra en su exposición ante todo en "las tres conferencias sobre 'La esencia del habla', pronunciadas en el invierno de 1957, publicadas en el volumen De camino al habla" ${ }^{100}$, texto este que me consta Arango no conocía por los tiempos de mi entrevista con él. El último trabajo de Heidegger mencionado por él es la conferencia “... 'La palabra', dictada bajo el título de 'Poetizar y pensar' en el Burgtheater de Viena a mediados de 1958”. La lista en el texto de la Introducción a Heidegger, de Gianni Vattimo es más extensa ${ }^{101}$. Para no fatigar solo indicaré dos conferencias muy ligadas a nuestro tema y que no indica el profesor Gutiérrez A: “El origen de la obra de arte" (1935) y "La cosa" (1950). Esta última es muy importante porque en ella desarrolla la noción de Geviert (Cuarteto, las dimensiones del mundo): Estamos sobre la tierra, bajo los cielos, ante los divinos, con los mortales, entre las cosas. Las palabras que definen el "Cuarteto" son de

\footnotetext{
99 Ibíd., pág. 30.

100 Ibíd., pág. 30.

101 Gedisa Editorial, 1996 (1985).
} 
Hölderlin. La otra conferencia también es muy importante. Una sola indicación: ahí Heidegger distingue entre dos sentidos de poesía: la poesía con la palabra alemana Dichtung es la esencia de las artes; la poesía con la expresión latina (Poesie) es la obra de arte de la palabra, la cual "tiene un lugar insigne en el conjunto de las artes".

Debe ser como una pregunta por lo que somos, ya sabemos que el lenguaje es lo que nos hace

Esta es una frase de Arango en una entrevista. ¿Afirmación fuerte, verdad? He señalado los cambios en la comprensión de la filosofía $-Y$ por supuesto de la poesía- que llevan a Heidegger a la propuesta de pensar tras el poeta. Igualmente nos hemos detenido en los trabajos en los que Heidegger se refiere al tema. Intentemos señalar las razones del cambio en la autocomprensión de la filosofía.

Sabemos que el único pensamiento de Heidegger es el del ser, y podemos conjeturar que algún cambio en la concepción de la relación entre ser y lenguaje tuvo que haber habido para este cambio. No olvidemos además lo que dice el profesor Gutiérrez A.: que el cambio en la autocomprensión de la filosofía y en la separación tajante entre filosofía y poesía se presenta "una vez se entrevén las insuficiencias de la determinación filosófica tradicional de lo que es el ser humano”. La vía a seguir $\underline{\text { entonces es la de ver los cambios en esta relación ser-lenguaje-ser humano. Y para }}$ ello es preciso partir de Ser y tiempo. Y ver luego qué cambios se presentan en esa $\underline{\text { concepción en los años treinta. }}$

A uno lo asusta la manera como Heidegger habla: "Se trata de comprender el ser del ser cuyo ser consiste en comprender ser", dice una frase clave de Ser y tiempo traducido por José Gaos. La frase completa sería: “Teniendo como propósito plantear la pregunta por el sentido de ser, se trata de comprender el ser del ser cuyo 
ser consiste en comprender ser". Trabalenguas, pero claro que el pensador tiene sus razones para hablar así, porque lo dicho es tremendamente preciso: una expresión sintética que expresa el propósito y el método de la fenomenología hermenéutica de Ser y tiempo. Dicha además con uno de los términos centrales de ese libro: comprensión. No voy a intentar hablar como él: uno tiene el derecho de intentar entenderlo así corra el riesgo de empobrecer una expresión precisa. O como dice Arango en el fragmento de mi entrevista: “Sí, yo sé que Heidegger es un filósofo muy difícil, que uno nunca puede llegar a decir que entendió; pero le toma ciertas cosas que le llegan a uno, que lo marcan y ya están en uno, de alguna manera..." Arriesguemos. El propósito central de las quinientas páginas en formato grande que constituyen Ser y tiempo es plantear una pregunta, la pregunta por el sentido del ser. Por eso dije: "teniendo como propósito plantear la pregunta por el sentido del ser". Sobre esto, que es el propósito de Ser y tiempo, el profesor Ramón Pérez Mantilla en la reseña sobre el libro Heidegger, de Steiner, formuló una síntesis magistral, de esas que uno puede hacer después de estar casi cuarenta años meditando un autor:

Otra de las fallas de Steiner hace relación al hecho de que en la parte del libro dedicada al análisis de Ser y tiempo, Steiner concede demasiado a los aspectos más llamativos de esa obra, descuidando su importancia desde el punto de vista estrictamente filosófico o metodológico, que es el de encontrar un nuevo punto de partida para el filosofar. Tal vez en relación con esto esté el que Steiner no destaque suficientemente el carácter específico de la pregunta por el ser como pregunta por el sentido del ser, o sea por el modo como el ser se abre al hombre, hecho que explica su conexión con el problema de la verdad. Seguramente se encuentra también en ello la razón de que Steiner no se tome el trabajo de aclarar el término alemán Dasein, cuya correcta comprensión impide cualquier interpretación existencialista de la analítica existencial (Subrayado LHV).

En Ser y tiempo Heidegger busca comprender el ser del hombre, ser que, para él, está determinado por la comprensión del ser: el hombre es comprensión de ser, Dasein, o sea, ahi del ser. Y va a buscar al ser a partir de la comprensión que de él tiene el hombre. Esto que parece tan extraño no lo es tanto. Los seres humanos comunes 
y corrientes, vendedores de dulces y tenderos, han venido a este mundo y están determinados por unas circunstancias que no han escogido y a partir de esas circunstancias adelantan unos proyectos. Por ello, están ocupados en sus cosas, y en estas ocupaciones usan los útiles que les sirven para ellas. Heidegger muestra cuál es la condición para poder usar los útiles: la comprensión del ser de sí mismo y de los utensilios que le sirven para adelantar sus propósitos (Voy a hacer tal cosa, requiero tal plexo de útiles, hacer tales contactos...) Estos útiles, estos enseres, se remiten los unos a los otros de la manera en que lo hacen los signos; en el fondo son signos. Es preciso entonces comprender esas remisiones que están dadas en el lenguaje. De una manera técnica lo dice Vattimo ${ }^{102}$ :

...el signo manifiesta la esencia de toda cosa intramundana. Pero hay un segundo sentido más profundo en el que el signo revela la mundanidad del mundo y el ser de las cosas. En efecto, se puede decir que si el mundo es la totalidad de los instrumentos del hombre, los signos son un poco como las "instrucciones para usar" dichos instrumentos. De hecho aprendemos a usar las cosas no tanto viéndolas usar o usando todos los instrumentos de que está constituido el mundo, sino principalmente a través de los discursos que nos ponen al corriente sobre el uso de las cosas.

El punto de partida para el pensar filosófico en este Heidegger de 1927 no es un hombre que está conociendo, con unas gafas muy lucientes, sino, digamos como ejemplo, un mecánico engrasado debajo de un carro, y poniéndose a considerarlo encuentra que la manipulación que le ennegrece las manos al mecánico está llena de lenguaje. A ese mecánico que sufre las limitaciones que le propone el hecho de haber nacido en un medio determinado, que no le permite estar estudiando en los Estados Unidos, que lo obliga a ganarse el pan de una manera que no es buena, con toda seguridad. Todo esto se llama en Ser y tiempo "Analítica existenciaria": hay que partir del ser del hombre corriente para entender esa palabrita que desveló a Parménides, Platón y Aristóteles: ser, la palabrita de relación, esa palabra que está en el lenguaje, el

102 Obra citada, pág. 31. 
cual es el que le da el orden del mundo (La expresión es de Arango en un poema) en donde se mueve el mecánico y todos nosotros.

Dejemos que esto nos lo diga en términos técnicos Carlos B. Gutiérrez A.: "Recordemos que en el comienzo de Ser y tiempo, superando la fundamentación egocéntrica de la filosofía en la conciencia, Heidegger concibe la existencia humana como un ahí, como un ámbito abierto en el des-encubrirse y en el encubrirse del ser en general. [...] Existir es [...] ser relativamente al salir a luz y encubrirse del ser en la comprensión de ser en que consiste el ser del hombre”. Y dejemos que él nos diga al menos parcialmente en qué consiste el cambio que se da en los años treinta, el cual está ligado a lo que se llama la Khere, el giro o vuelco del pensamiento de Heidegger: "El pensar filosófico es visto como un corresponder al reclamo de ser, del que se dice: 'Este corresponder es un hablar. Está al servicio del habla'. Se llega así a entrever que el pensar la esencia de ser sea al mismo tiempo pensar la esencia del habla, es decir, que la esencia de ser sea también la esencia del habla. [...] En esto pues consiste el "giro": en Ser y tiempo se había dicho que el ser del habla tenía sus raíces en la apertura del ser-en-el-mundo en la luminidad del ser, pero no se había llegado a que la esencia del ser fuera la esencia del habla"103.

En suma: el orden del mundo se da para Heidegger en el lenguaje, en el que se presenta la apertura del ser. El hombre es comprensión de ser, un saber del ser que no se puede dar de otra manera que en unas palabras que tienen unas reglas sintácticas, gramaticales.

Es curiosa en esto la coincidencia con Arango. Ya vimos que en una entrevista señala "el lenguaje es lo que nos hace". Nos da el orden del mundo en que nos

103 Obra citada, pág. 31. 
movemos. En un poema habla él de un indígena que vende pájaros en la plaza de mercado usando dice, la lengua de los vencedores, el castellano. Pero tras la lengua impuesta:

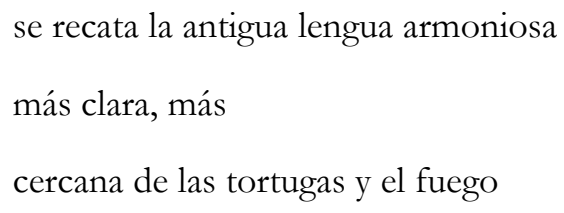

Pero Arango no dice solo esto. Dice que el lenguaje piensa en el indígena. Estamos frente a un poema de un profesor de filosofía de lenguaje, que debe seguir ahí de alguna manera cuando hace poesía. Pero que es como el Abel Martín de Antonio Machado: “Abel Martín no pone en versos sus ideas, aunque estas lo acompañen siempre”. O sea que debe tener sus buenas razones Arango cuando dice: "la antigua lengua armoniosa piensa en él". Primero que todo hay que señalar que toma un caso particular del lenguaje: el de un indígena, no de un ciudadano común y corriente. Así como constantemente toma casos límites en el uso del lenguaje: ciegos, sordos, sordiciegos. Hay que tomar en serio eso de que el lenguaje piensa en él. Heidegger en la conferencia "Hölderlin y la esencia de la poesía" distingue dos planos del lenguaje: está, es verdad, el plano del lenguaje en el que es instrumento que nos sirve para comunicarnos, el plano que más conocemos. En ese plano el lenguaje parece depender de nosotros. Pero también está el plano en el que el dependemos de él. Dice Heidegger ahí: "Pero ¿en qué sentido es [...] un 'bien’ del hombre? El lenguaje es su propiedad. Dispone de él con el objetivo de comunicar las experiencias, decisiones y estados de ánimo. El lenguaje sirve para entenderse. Como instrumento apropiado para ello es un 'bien'. Solo que el ser del lenguaje no se agota 
en ser un medio de entendimiento. Con esa determinación no se toca su auténtico ser, sino que meramente se menciona una consecuencia de su ser. [...] El lenguaje no es un instrumento que esté a nuestra disposición, sino que es ese evento que dispone de la suprema posibilidad del ser del hombre"104.

Quizá esto permita entender por qué hay que ir al poeta y pensar tras el poeta en este vuelco de la concepción de la filosofía. El poeta no toma el lenguaje como instrumento sino que se abandona a él; no es el señor del lenguaje, sino que se somete al señorío de este. Y en ese abandono la experiencia poética permite que el lenguaje hable. Por eso señala Carlos B. Gutiérrez A.: "El poetizar es siempre experiencia poética con la esencia del habla”. Es posible que esto parezca mística desatada. Creo incluso que todavía no estoy seguro de entender esta última afirmación. Pero si apelamos a testimonios de grandes poetas colombianos, encontramos que en la extraña ocupación suya hay algo de eso. Silva decía que los poemas se hacen en uno y luego salen. La relación de Arango con la palabra la califiqué, y parece que aprobó esa manera de decir, la califiqué digo, de "vicio erótico" con la palabra. Se lo dije porque en un poema sobre Fernando González, dice de este viejo ${ }^{105}$ :

\footnotetext{
A veces saborea y saborea una palabra, Una manera de decir oída en la niñez.

Así se acaricia una teta de muchacha
}

${ }^{104}$ Martin Heidegger, "Hölderlin y la esencia de la poesía", en: Trad. de José María Valverde, Ariel, Barcelona, 1983, pág. 58. (Mezclo la traducción de Valverde con la que viene en el texto de Vattimo citado, pág. 113).

${ }^{105}$ José Manuel Arango, Poesía completa, Editorial Universidad de Antioquia, Medellín, 2003, pág. 268. 
Finalmente, Aurelio Arturo, en la cita que ya he transcrito. Hay que ver el entusiasmo de Danilo Cruz Vélez ${ }^{106}$ :

El tema de "Palabra" es el lenguaje del hombre. Este es posiblemente el primer gran poema sobre este tema escrito en nuestra lengua. Cuando lo leímos por primera vez, en Golpe de dados, quedamos asombrados de que la poesía, es decir, el lenguaje poético, pudiera esclarecer el lenguaje mismo, sacando a la luz aspectos de su ser ignorados por la filosofía del lenguaje y por las ciencias particulares del lenguaje.

Heidegger intenta escuchar a unos poetas, cuya lista es más larga que aquella que nos dio Arango. Agreguemos a Stefan George, Hebel, René Char. Podemos entrever lo que gana la filosofía en el intercambio. Y ¿qué gana la poesía? Dice el mencionado Steiner, citado por Pérez Mantilla: "Me parece que Heidegger en ciertos momentos es un lector de poesía que no tiene paralelo en nuestro tiempo, un recreador del origen y del sentido del poema, que se eleva muy por encima de la aburrida miscelánea de la crítica literaria y del comentario académico. Solo ahora la lingüística y el análisis de la literatura han apenas comenzado a percibir la riqueza y la trascendencia de sus propuestas”.

Es sano no dejar la cautela cuando se trata de hablar de Heidegger. Ya vimos lo que nos decían Arango, Steiner y Pérez. Pero hay que arriesgar. Rememoremos la frase de Carlos B. Gutiérrez A: "Recordemos que en el comienzo de Ser y tiempo, superando la fundamentación egocéntrica de la filosofía en la conciencia..." "Superando la fundamentación egocéntrica de la filosofía en la conciencia..." Esta frase nos da una clave para intentar una síntesis. El pensamiento de Heidegger busca desprenderse del ego. Lo intentó en Ser y tiempo: para plantear la pregunta por el sentido de ser, digamos que "pone a hablar" al Dasein, conversa con él y toma nota.

${ }^{106}$ El misterio del lenguaje, Planeta, Bogotá, 1995, Pág. 71. 
Cuando en los treinta este camino se revela inconveniente, se tuerce el camino del pensamiento. Interroga entonces a los poetas. En cualquier caso procura salir del ego. ¿Habrá algo de esto en la concepción que tiene Arango de la poesía? Dijo en una entrevista de 1995 una de esas frases suyas que obligan a mirar con la nuca, porque es grande el porrazo: "La poesía nos enseña a ser... Mejor a no ser". Después de 6 años de darle vueltas a la frase, en mi entrevista le pregunté lo que quería decir con esa frase. Me dijo entonces: "Puede ser en el sentido de renunciar al ego y a todas esas cosas y abrirse uno de otra manera (Muy humilde) a las cosas, al mundo, a la belleza del mundo, a los diosecitos... y no tener pretensiones, en primer lugar la gran pretensión de ser inmortal, de que después de esta vida hay un premio que da un Dios. Tal vez vaya como por ese lado". ¿No es este, por otra parte, el vaciamiento de que habla constantemente María Zambrano?

\section{La obra de Arango y el pensamiento de Heidegger}

Es claro que Arango no ve ninguna incompatibilidad en el cultivo de las dos disciplinas nacidas de la misma raíz, el asombro, y lo es también que ve diferencias entre las dos. Creo que la filosofía era para él una manera de acercarse al mundo. Repito algo que ya dije: si la medicina era el trato de Williams con el mundo; la filosofía lo era para Arango: "deformación profesional".

De ahí, creo yo, la mirada que como ya dijimos el mismo Arango califica de metafísica y que reconoce como propia en la frase de González que convierte en el verso final de "Pensamientos de un viejo": "Los senos, lo primero que se pudre". De ahí también que podamos ver variadas relaciones entre filosofía y poesía en su obra.

En el ensayo sobre Williams (págs. 60 y 61) dice lo siguiente: 
Depende tanto

de

una carretilla

roja

Y qué es lo que depende? La vida nada menos. La carretilla ayuda a dar la vida. En ella, como en los zuecos de Van Gogh, está el sentido de la tierra. La brega y la alegría de bregar. Y la carretilla está puesta ahí en el poema con la misma sencillez con que está puesta ahí en la huerta entre los pollos blancos.

Es clara aquí la referencia a "El origen de la obra de arte", en la cual el primero de los tres ejemplos utilizados por Heidegger es precisamente el cuadro de unos zapatos pintados por el holandés, pintura en la que encuentra Heidegger que se revelan la vida y la muerte de una campesina, sus propósitos y afanes firmemente insertados en una tierra que cobija y acoge. También es clara la referencia a otras obras de Heidegger en el comienzo del ensayo sobre Aurelio Arturo ${ }^{107}$ :

"La poesía ha sido pensada, por un pensamiento muy lúcido y que se funda en metáfora honda, como la construcción de una casa, de una habitación para el hombre. La palabra sería, en esencia, morada. Aurelio Arturo construyó en sus poemas tal habitación humana. Morada al sur es el título de su único libro".

"La palabra sería, en esencia, morada" ¿Tal vez "La carta sobre el humanismo"? Quizá. Pero también es probable que venga de “¿Y para qué poetas?”, texto recogido en Caminos del bosque. "Metáfora honda": Hölderlin: "Poéticamente habita el hombre sobre la tierra" (En el ensayo "Hölderlin y la esencia de la poesía", Heidegger va considerando una a una cinco frases de Hölderlin tomadas de poemas y de cartas; el verso en cuestión es el último de estos "lemas" -El verso también es materia de un ensayo aparte recogido en el volumen Conferencias y articulos).

${ }^{107}$ José Manuel Arango, "Aurelio Arturo y la poesía esencial", en: Aurelio Arturo. Morada al sur y otros poemas, Norma, Bogotá, 1992, pág., 49. 
En los ejemplos citados Arango se apoya en Heidegger para pensar la obra de Williams y de Arturo. Este es un caso de relación entre filosofía y poesía.

Otro caso diferente creo que ocurre en un poema recogido en Montañas, "Señal”, el cual tiene trazas del parágrafo 17 de Ser y tiempo. Probablemente este libro de Heidegger alimentó este poema. Se lo dije a Arango y no lo desaprobó, como se puede ver en mi entrevista. Es un poema en el que el yo cristalizado en los poemas de Arango se detiene a enderezar una señal, "una flecha tosca" que se ha torcido y que en lugar de señalar el camino apunta al abismo. (Ya me detendré en este poema más adelante). También la filosofía de los presocráticos Anaxágoras y -quizáAnaxímenes despunta en un par de los poemas "Póstumos". Con el primero polemiza. En el "Himno al sol"108, le dice Arango al astro:

\author{
Los filósofos dicen que no eres un dios \\ dicen que no eres más que una piedra ardiente un globo de fuego \\ que no eres tú quien engendra y hace brotar la vida en el pantano \\ ni crías el oro en la veta del recoveco de la montaña
}

\begin{abstract}
Pero yo te saludo como un dios
porque sé que eres tú y nadie más que tú abuelo sol

quien ahora mismo está engendrando en el aire los bichos

y haciendo nacer la gusanera en la podre del lodo

y engendrando las pepitas de oro en el recoveco de la montaña
\end{abstract}

Es sabido que Anaxágoras ${ }^{109}$ fue desterrado de Atenas con el pretexto de que había afirmado que el sol no era un dios sino un disco de piedra calentado al rojo y

108 Poesía completa, pág. 339.

${ }^{109}$ W.K.C. Guthrie, Los filósofos griegos, F.C.E., México, 2002 (1953), pág. 65. 
poco mayor que el Peloponeso. Anaxímenes ${ }^{110}$ pensó que todo venía del aire porque este se hacía rarefacto o se condensaba, en suma, podía ser cálido (hálito) o frío (soplo). Esto parece traslucirse en el poema "Cautela"

\author{
Sé cuidadoso: distingue \\ el hálito que aviva una llama \\ del soplo que la extingue
}

\title{
La muerte de Dios
}

No voy a tratar acá el tema de lo sagrado. Intenté un acercamiento en mi libro sobre Arango. Ya me detuve en ello en el anterior capítulo. Solo quiero retener, de pasada, algo que indica Vattimo, que pone en conexión el "ser-para-la-muerte", la palabra auténtica, el silencio y lo sagrado, palabras que son importantes en José Manuel $^{112}$ :

La physis pensada como lo Sagrado que se da a través del silencio del poeta es pensada sobre el modelo de la vida viviente. No podemos no conectar éste con la insistencia de Heidegger sobre el ser-para-la-muerte. A través del silencio del poeta habla algo Sagrado que es la naturaleza como crecimiento, como temporalidad vivida. La temporalidad vivida, como parece, ante todo, por Sein und Zeit, está profundamente marcada por el ser-para-la-muerte. Se delinea un nexo entre Sagrado, physis, tiempo viviente, ser, ser-para la muerte, bajo cuya luz debe verse también el problema de la relación lenguaje-silencio.

En mi entrevista, Arango comentó el interés que despertó en él este "ser-para-la-muerte": "Me interesa esa actitud ante la vida que es capaz de vivir sin dioses... o sin Dios (Mejor que sin dioses, sin Dios), porque es afrontar la vida frente a la muerte, "ser-para-la-muerte", como dice Heidegger, sin pensar en otra vida, inmortal. Lo cual no implica que uno niegue los dioses". Liga entonces Arango el "ser-para-la-muerte" al desengañarse de la posibilidad de "otra vida, inmortal".

\footnotetext{
110 Ibídem, pág. 39.

111 Poesía completa, pág. 319.

112 "Heidegger y la poesía como ocaso del lenguaje”, En: Más allá del sujeto, Gianni Vattimo, pág. 79.
} 
Antes de tocar el tema de la muerte de Dios, es conveniente, también, rozar al menos el asunto del silencio (Lo trato con algún detenimiento en un apartado de mi libro-: "Lo sagrado y el silencio"). Tal vez las observaciones más agudas sobre el silencio las hace el editor de la antología para la revista española Palimpsesto. Son dos. Dice, en primer lugar, Francisco José Cruz $^{113}$ que en la poesía de Arango calla el poeta, para que hable la vida. En lo cual coincide con David Jiménez ${ }^{114}$. Por otra parte, en el mismo ensayo ${ }^{115}$, me hizo notar que hay un procedimiento que aparece en otros poemas y está al servicio del silencio: "las palabras, de una u otra forma, según el poema, están al servicio de algo que callan y sólo gracias a la distribución audaz del silencio que propician, ese algo se revela a través de un hecho o de una imagen. [...] Es frecuente que Arango comience poemas con conjunciones copulativas o disyuntivas e incluso con partículas adversativas...”

El tema de la muerte de Dios pudo haberme llegado a través de algunos libros. En El alma romántica y el sueño, de Albert Béguin, un libro en boga en Colombia durante los ochentas. Allí aparece el poema de Jean-Paul: "Discurso ante los discípulos dormidos: no hay Dios". Por otra parte, la serie de cinco sonetos de "Le Christ aux oliviers", de Gérard de Nerval, la cual tiene como epígrafe unos versos de

113 “Acercamientos a José Manuel Arango", en: José Manuel Arango, La tierra de nadie del sueño. Poemas póstumos, Ediciones DesHora Intergraf, Medellín, 2002, pág. 74.: "sus propios poemas que, con su mismo sigilo, empezaba a influir en mi necesidad -mucho más tarde desarrollada- de hacer una poesía descargada de contundencia, donde la opinión personal sobre la vida pesara menos que la vida misma".

${ }^{114}$ En el prólogo de Poemas escogidos: "Un poeta de la naturaleza. Eso ya suena hoy bastante anacrónico y casi por fuera de los confines de la poesía moderna. En la obra de José Manuel Arango significa, tal vez, lo contrario de un anacronismo. [...] La naturaleza no limita simplemente con el espíritu y la muerte. Esos límites han sido transgredidos y el árbol está amenazado igual que el pez. Cercada por las obras del hombre, aparece rescatada en el poema, las naranjas colgantes sobre el muro, la hierba entre el asfalto, los pichones anidando en el baldío. Invencible, como la faz aparente de un misterio que no acaba de manifestarse. [...] A eso también se le llama vida: las palabras la captan en su estremecimiento, no en su mensaje que escapa con la rapidez de un "ágil coletazo".

115 Págs. 76, 77. 
Jean-Paul: "Dieu est mort! le ciel est vide... Pleurez! Enfants, vous n'avez plus de père”. A su vez, el último verso del poema de Nerval ("Celui qui donna l'âme aux enfants du limon") da nombre a un estupendo libro de Octavio Paz: Los hijos del limo, el cual sigue el desarrollo de la poesía desde los románticos alemanes e ingleses (Hay que recordar que el romanticismo alemán, particularmente Hölderlin, y el nobel mexicano son importantes en la obra de Arango).

En mi entrevista, como ya se pudo ver, Arango me dice que, en parte, su afirmación de que "la poesía nos enseña a ser, mejor... a no ser" significa "no tener pretensiones, en primer lugar la gran pretensión de ser inmortal, de que después de esta vida hay un premio que da un Dios". Más adelante, me precisó un poco más la significación de la muerte de Dios:

LHVT: En mi ensayo busqué una palabra para definir la intención de su poesía. Y terminé escribiendo a la manera de Paz algo así como: Arango: mujer que es noche que es lluvia que es agua que es... Si es eso, es algo monstruoso lo que se está diciendo con esa expresión. ¿Eso puede ser la voz del Caos?

JMA: Sí. Sí. Pero es que la idea de que existe Dios es la idea de que existe el orden. Si no existe un Dios no existe ni orden ni un sentido trascendental de la vida, y la vida es azarosa... Lo que sucede es que hay maneras de acercarse a eso. Hay maneras muy dramáticas. En Barba hay una manera dramática. Yo tengo una manera más tranquila, sin que eso deje de causar a veces incluso pavor. Pero sin ahuecar la voz, sino aceptar de una manera casi budista, casi oriental, la falta de sentido de las cosas y cómo el sentido se lo tiene que dar uno mismo, y hacer su propia vida, darle un sentido, porque sentidos trascendentales no hay. Algo como eso. Pero sin dramatismo, sin alzar demasiado la voz...

\section{Filosofía y poesía en el siglo XX colombiano}

Encontramos el tema de la muerte de Dios en el comienzo mismo de la poesía colombiana del siglo XX. Con Silva, dice David Jiménez en "Sobre la presente 
Antología"116 (Págs. 20, 21): "El apóstrofe romántico, lleno de fe religiosa en la capacidad del universo para responder, comienza a hundirse en la constatación de que el mundo superior está deshabitado. Antes el apóstrofe era una invocación, una exhalación liberadora. Ahora es la voz del hombre aterrado que se escucha sólo a sí mismo, una pregunta sin respuesta". Como en Arango, no hay trascendencia para Silva. Comentando el famoso "Nocturno", agrega Jiménez (pág. 21): “en ninguna parte se nos habla del milagro de la fe o de la esperanza en la resurrección de los muertos. Por el contrario, se equipara la muerte con la nada y el infinito con la total oscuridad [...] El poema de Silva omite todas las palabras que el poeta religioso utiliza para exorcizar la muerte: Dios, salvación, cielo, eternidad. Es la imaginación la que, por un instante, sobrepasa los límites. Si se trata de un éxtasis, no es aquí el éxtasis de la visión mística sino del delirio imaginativo".

En el caso de Arango, y de acuerdo con su testimonio, una convicción como la de lo sagrado está unida a una reflexión filosófica que puede venir de Heidegger. En el caso de Silva, aunque no me es posible concluir nada por el momento, sí me atrevo a conjeturar algo parecido, en este caso con Nietzsche. En la cita de David Jiménez sobre Silva aparece la transvaloración de todos los valores, el escepticismo, el alejamiento de todo dogma. Al comienzo de su "Poesía y poetas colombianos" habla Charry Lara sobre Silva (Pág. 16): "la inquietud metafísica, el afán de conocimientos, la sensualidad, la obsesión por el análisis, el destino tiránico, hacen de su vOz aquella a la que ha de acudir quien pretenda escuchar la más intensa y desolada de nuestra poesía”.

116 Antología de la poesía colombiana, Selección y notas bibliográficas: David Jiménez, Grupo Editorial Norma, Colección Cara y Cruz, Bogotá, 2005. 
Por otra parte, la relación filosofía y poesía aparece en los debates de finales del XIX. En este caso con Baldomero Sanín Cano. En el texto "Rafael Núñez, poeta", aparece con toda claridad. El debate enfrenta a Sanín Cano con el autor de la letra de nuestro himno nacional, y coautor de una constitución política que duró más de 100 años: Dice David Jiménez ${ }^{117}$ :

Sanín Cano desenmascara en los versos de Núñez, precisamente, un contenido que proviene de la filosofía pero que con anterioridad había sido convertido en lugar común para poder llegar con él a un público amplio, conmoviéndolo con la supuesta profundidad de los temas y de los conceptos. [...] Sanín Cano asegura, en una nota de pie de página, que prefiere la duda expresada sinceramente y con brío por un joven poeta, a la metafísica de segunda mano con que el supuesto poeta filósofo amasa silogismos rimados "como quien aploma una tapia o cuadra un cercado". En otro pasaje afirma que Leopardi es poeta y filósofo, no poeta filósofo, pues esto último es "menjurje indigesto". La poesía de Núñez puede calificarse de filosófica en ese mal sentido: las ideas allí son préstamos, material ajeno, lugar común, no producto natural de sus combates interiores, por lo cual el crítico la descalifica como insincera, antipoética y, peor aún, como instrumentalización política de una moda intelectual.

Es preciso estudiar la relación entre filosofía y poesía colombiana del siglo. La filosofía aparece involucrada con lo que podíamos llamar el sentimiento de la vida del siglo XX. Porque aquello que sentía y pensaba Silva es lo que quizá todavía están sintiendo y pensando al menos unas capas de colombianos: la orfandad y el cielo vacío. Es preciso pensarla porque ya desde el comienzo se discutió la relación. Y porque esta relación plantea el problema de si no hay una especie de filosofismo en la poesía de Silva y de Arango. Porque es claro que uno se puede preguntar si la presencia de ideas no daña la poesía. Creo que no hay filosofismo en la poesía de Silva (Aunque algún crítico señaló, de una manera torpe, que los aciertos de las Gotas amargas eran filosofía barata y retintín monótono) ni en la de Arango; siempre están

117 "Miguel Antonio Caro: bellas letras y literatura moderna", En: Miguel Antonio Caro y la cultura de su época -Rubén Sierra, editor, Universidad Nacional de Colombia, Sede Bogotá, 2002, págs. 252, 253. 
ahí las ideas pero de un modo poético. ¿Cuál es ese modo?: es el problema al que se enfrentará el capítulo de la relación entre poesía y realidad.

Ahora bien: sí hay casos de relaciones problemáticas en la poesía del siglo XX, al menos de la manera como ven los críticos. Veamos algunos ejemplos. Según Cobo Borda (en "Tradición de la pobreza", un escrito temprano, recogido en Historia de la poesía colombiana. Siglo XX. De José Asunción Silva a Raúl Gómez Jattin), Valencia quien, según vimos, fue comparado con Nietzsche, “aspiraba a suscitar grandes combates; engendra en cambio, fintas verbales. Tan vacuas como sus sonetos filosóficos” (pág. 41). De Cote Lamus: “Hay también un afán filosófico que arruinará, luego, varios pasajes de Estoraques pero que cuando surge, necesariamente, del curso de la evocación da a Cote su signo distintivo: progresiva conquista de una realidad e interrogación acerca de lo que ella significa" (Pág. 53). Dice David Jiménez, sobre Rafael Maya ${ }^{118}$ : "En la poesía de Maya todavía es posible encontrar el tema de la armonía cósmica, con sus imágenes de cielo estrellado y de abismo radiante, como en Pombo, Silva y De Greiff. Pero en Maya no es motivo de éxtasis sino de meditación filosófica y religiosa [...] En los versos de Maya se desarrolla más bien una reflexión que no destruye pero sí atenúa el sentimiento de asombro. Si la mudez de la noche todavía puede parecer sublime, ya no se debe al horror que produce la imagen del vacío, como en Silva, o al júbilo del concierto universal, como en Pombo, sino a la certeza intelectual de que es el pensamiento humano el que proyecta esplendor y sentido de infinitud en el espectáculo nocturno".

Para cerrar esta reflexión sobre el tema de la relación entre filosofía y poesía y sobre el tema de la muerte de Dios: Oía ahora a Machado, en una versión de Sabina y

118 Ibídem, págs. 38, 39. 
Serrat ("Caminante son tus huellas el camino y nada más). ¿Qué dice este poema, "Del camino", de Arango (Pág. 250):

No hay camino, dijo el maestro.

Y si acaso hubiera un camino nadie podría hallarlo.

Y si alguien por ventura lo hallara

No podría enseñarlo a otro

Este poema, sobre Machado, hace pensar en Gorgias, por la forma. Y por el escepticismo. “...Gorgias escribió [un libro] al que tituló "Sobre la Naturaleza o lo No existente", en el que se propuso demostrar tres cosas: a) que nada existe; b) que si existiese algo, no podríamos conocerlo; c) que si conociésemos algo, no podríamos comunicarlo a nuestro prójimo ${ }^{119, "}$.

\section{Poesía y lenguaje}

¿Qué caminos pudieron conducir a José Manuel Arango a la reflexión sobre el lenguaje? Por supuesto está su formación:

Estudié en una universidad pequeña, es decir pequeña en comparación con las grandes de allá, la Universidad de Virginia Occidental, con la que la de Antioquia tenía intercambio. Estudié literatura y filosofía. De la filosofía de allá lo que me interesaba era la filosofía del lenguaje, así que hice un área mayor en literatura. Fue cuando tuve la oportunidad de darme cuenta de lo que era la poesía norteamericana ${ }^{120}$.

La formación de Arango, entonces, y además la consideración de la relación entre filosofía y poesía conduce, como hemos visto en este capítulo, forzosamente al

${ }^{119}$ W.K.C. Guthrie, Los filósofos griegos, F.C.E., México, 2002 (1953), pág. 81.

120 Babel $N^{\circ} 4$, Medellín, Diciembre de 1996- Marzo de 1997), pág. 14. 
"problema del lenguaje”, expresión que habría que precisar. Formación, relaciones entre literatura y filosofía se unen, claro, al hecho de ser poeta en una época en la que, para el poeta, es problema la poesía y en la que hay que "ceder a la iniciativa de las palabras". Ahora bien, si atendemos a frases como la colocada en un intertítulo anterior ("ya sabemos que el lenguaje es lo que nos hace"), hay que decir que la "raíz" misma de su poesía lo conducía. Se trata de reflexionar sobre lo que somos. Si la motivación de Arango pudo ser múltiple, tendré que afirmar que no se puede esperar menos que una riqueza enorme en su reflexión. Como diría un profesor mío, la reflexión del profesor de filosofía del lenguaje y poeta daría para una tesis de doctorado. Acá no pretendo otra cosa que señalar que, al igual que en los casos del uso de la razón y de la relación entre literatura y filosofía, Arango es una referencia privilegiada.

Para el señalamiento que busco ahora simplemente tomaré unos ejemplos de sus poemas: los que se refieren a la reflexión sobre el lenguaje de la poesía y el lenguaje corriente. ¿Por qué? Es natural pensar que en un poeta moderno tenga amplia cabida una reflexión sobre la palabra poética; no lo es tanto que pueda tener una reflexión sobre el lenguaje en general. Finalmente indicaré cómo al parecer el tema del lenguaje puede tener una tradición en la poesía colombiana del siglo XX. Solo hago notar que los dos primeros libros de Arango, donde todo es signo, darían para una consideración honda: "el mar repite su sílaba redonda", escribe el viento, "la ciudad es un texto", "la lengua del agua"...

\section{E1 lenguaje de la poesía}

En "Otros poemas" aparece un texto (Pág. 287) que lleva el título "Escritura: 
con la uña
hacerle con la uña una raya
y echarla a rodar por la ciudad

Tal vez la ciudad te la devuelva

y quizá traiga dos rasguños,

uno al lado del otro,

hermanos.

Agradecido la recibirías

En tu palma-

Es muy habitual la metáfora del lenguaje como moneda: medio de intercambio. El título mismo del poema muestra lo azaroso de la comunicación poética en estos días en que el lector de poesía debe ser poeta. Lo curioso es que llamándose escritura se ocupe de la escritura también por el lado del lector de poesía. Pero la moneda tiene dos caras. La escritura poética no tiene más remedio que partir de la moneda corriente, de la palabra diaria, de la lengua de todos. Y hacer en ella un trazo casi imperceptible, que puede pasar inadvertido. Y, como señala Valéry, partiendo de palabras tremendamente imprecisas, hacer un lenguaje de alta precisión.

"Palabra de hombre" es otro de los poemas a considerar. Curioso el nombre, porque se refiere, en primer lugar, a la reflexión poética. Otra vez la moneda. Las extrañas operaciones del poeta con la moneda. El poeta trabaja con el lenguaje corriente y se somete a unas experiencias que no son las del uso cotidiano. En "Cosas a un tiempo familiares y ajenas", escribí sobre este poema:

Arango se ha ocupado del límite en el que se encuentran lo familiar y lo extraño. $\mathrm{Y}$ ese encuentro está construido con palabras que son fruto de un largo oficio. Oficio que tal vez no consiste en otra cosa que en haber frecuentado las palabras. Quizá el lento viajero que es este poeta es un viajero que descamina los lugares del 
hábito echando "pa" tras" por los "lugares" del lenguaje, restituyéndose al lenguaje: finalmente, los poemas están hechos de palabras. 'Palabra de hombre': 'La palabra/ como una moneda/ sopesada en la palma,/ lanzada contra el muro de piedra/ para oír su timbre/ mordida/ para saber su ley'. Palabra sopesada, palabra oída, palabra mordida. Es curioso el nombre de este poema. Cuando estaba en la escuela primaria, cuando queríamos decir que algo era verdad, decíamos: "palabra de hombre". Creo que también se usaba para señalar que uno no se iba a "correr" en una promesa, que la iba a cumplir.

Largo oficio. Vicio "erótico" con la palabra que hace que ella se abra y palpite. En ese poema que hemos mencionado varias veces, dice que el viejo Fernando González 'A veces saborea y saborea una palabra,/una manera de decir oída en la niñez./ Así se acaricia una teta de muchacha'. Ese vicio erótico puede explicar esa capacidad para lograr que las palabras se miren entre sí, que se ajusten a lo que nombran, es decir que sean palabras ordinarias que abandonan lo ordinario en las extrañas configuraciones del lenguaje, las cuales finalmente no nos son más extrañas que lo que no vemos por el desgaste del trato cotidiano.

Tuve la suerte de hablar sobre este poema con Arango. Me dijo:

...esto: el enamoramiento, la catación del lenguaje que yo creo que es lo que debe tener todo poeta, y que es por lo uno se preocupa. Porque además cuando uno lee un poema lo que está haciendo es repetir unas palabras, y a veces se aprende versos enteros, fragmentos de poema de memoria, porque uno repite las palabras. En el poema de Fernando González aparece eso de saborear una palabra o una manera de decir.

La metáfora de Arango es "gastronómica". En el ensayo sobre la poesía de Echavarría ${ }^{121}$ dice: "El lector encontrará en su breve obra versos tan saboridos como estos..." (Sub. LHV) De ahí su gesto característico de llevarse los dedos a la nariz, como quien huele una comida exquisita, para hablar de una poesía estupenda... Extraña -Y admirable- relación del poeta con la palabra.

El poema final de En este lugar de la noche se llama también "Escritura":

la noche, como un animal

dejó su vaho en mi ventana

por entre las agujas del frío

121 "Una poesía para nuestro tiempo", En: El transeúnte paso a paso, Selección y prólogo de Juan Gustavo Cobo Borda, Colección "Premio Nacional de Poesía por reconocimiento", Universidad de Antioquia, Medellín, 1999, pág. 164. 
miro los árboles

y en el empañado cristal

con el índice, escribo

esta efímera palabra

La poesía se escribe con el vaho, con el hálito, de la vida. Palabra de la vida, indicación de la vida, que es también de la muerte. Palabra de la noche. Palabra efímera. Este poema tal vez cobre más resonancia si se lo pone en relación con un poema de Montañas: "Página en blanco":

\author{
Escribo \\ y la mirona, por sobre mi hombro, \\ escruta lo que escribo.
}

Siento en la espalda el tacto

de sus manos calizas,

adivino la mueca

de su ironía silenciosa.

\title{
Escribo
}

y la mirona, por sobre mi hombro,

lee

y al leer borra lo que escribo.

Una vieja obsesión de Arango, la conexión entre muerte y escritura, se pone aquí. Pero la muerte tiene figura concreta. Para decirlo con palabras de Arango, en el ensayo sobre Echavarría, "se figura y se personifica". Por otra parte, adquiere una mayor precisión el carácter efímero del poema "Escritura". Comentando dos lugares 
de Echavarría ${ }^{122}$ - ("El poeta es un hombre que/ vive y convive con la muerte" y "Yo siempre duermo con mi única fiel compañera,/ que me acaricia el rostro con sus manos de hollín", dice Arango: "La vivencia de la muerte y la convivencia con ella son, pues, una especie de trato amoroso. La muerte es la única fiel compañera. Su frecuentación es la que mantiene los ojos abiertos ${ }^{123}$, la que, lejos de excluir, permite la ebriedad del canto. Cada hombre debería aceptar el no saber y la indefensión que su cercanía trae...” David Jiménez interpreta este poema ${ }^{124}$ :

Escribir es un baile con la muerte cuya coreografía se va dibujando en los trazos de la pluma impaciente. Danza de la escritura del poeta sobre la página en blanco que da vida al poema y danza de la lectura de la muerte que va borrando lo escrito [...] ¿Es este un poema serio, trágico, una poética de la muerte en lenguaje popular? ¿O es una parodia alegre, jocunda, del más serio de los temas de la poesía moderna, esto es, la poesía misma, el acto de escribir y su relación con la muerte? ¿O es una síntesis de ambas?

Pero podemos también darle resonancia a estos dos poemas si consideramos un extraño poema del primero de sus libros:

\author{
la casa que reduce la noche a límites \\ y la hace llevadera \\ cuando el rugido de una bestia en el sueño \\ o las palabras que sin sentido \\ despiertan con todo ese extraño temor \\ surgen como restos de una oscura lengua \\ que desvela el origen y la amenaza
}

el techo que cubría un fuego manso

arderá

\footnotetext{
122 "Una poesía para nuestro tiempo", pág. 158.

123 En “Conversatorio con José Manuel Arango. El excesivo pudor”, pág. 20, dice José Manuel: "Bueno, la muerte está ahí, delante (o detrás de nosotros) todos los días. Y es tal vez la que nos hace abrir los ojos. Schopenhauer decía que es la musageta de la filosofía, y tal vez también de la poesía". 124 "La poesía de José Manuel Arango", En: José Manuel Arango, La tierra de nadie del sueño. Poemas póstumos, Ediciones DesHora Intergraf, Medellín, 2002, pág. 149.
} 


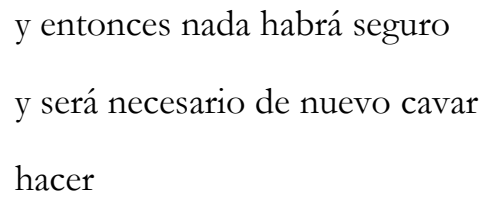

La escritura de la noche tiene sus angustias. Por eso el animal es a veces terrible - como el que según Arango miró Hölderlin. Creo que esta casa puede ser el lenguaje en general: él mismo aprobó la expresión heideggeriana del lenguaje como casa del ser. Un lenguaje que se ve amenazado por palabras que son resto de una oscura lengua. Oscuro es lo que da peso poético a la palabra del poema. Y esa amenaza lo es para todo lo que sugiere el poema simbolista, aquello a lo que da orden ese lenguaje: la casa propiamente y también la república y el yo. Este poema hace pensar en un libro que lleva el título de una frase del Manifiesto comunista: Todo lo sólido se desvanece en el aire. Sobre esta frase habló Ramón Pérez Mantilla en una entrevista que le hizo el profesor Lisímaco Parra París:

L. P.: Bueno: y su trabajo entonces sobre esa crisis tan profunda del marxismo, expresada en el Muro de Berlín gráficamente... ¿su trabajo de reflexión se orienta entonces por los caminos de la posmodernidad?

R. P. M.: Sí. Es decir, a recoger, digamos así, y conservar, del marxismo, su capacidad crítica, de demolición, como dice Marx en el Manifiesto: "Todo lo sólido se desvanecerá", la famosa frase que ahora recoge un autor.

L. P.: Marshall Berman...

R. P. M.: Marshall Berman. Es decir, esos puntos que hay en Marx, y que son innegables, de radicalismo destructor contra toda la serie de valores que pasaban por sagrados, incluyendo, como dice Marx, la familia, el honor, toda una serie de cosas que el mismo capital ya se encargaba de destruir: no había que hacer ninguna fuerza, ¿no? Por eso, y desde ese punto de vista, Marx veía una cosa positiva en el mismo ascenso de la burguesía y del capitalismo, que había que seguir llevando hacia adelante, había que seguir dándole toda su fuerza, hasta llegar, precisamente, a una situación como la de la postmodernidad hoy, que es precisamente eso de decir: "Se acabó el cuento, se acabaron todos los cuentos de hadas, incluso de golpe el gran ideal de la emancipación ilustrada -Que era el que había mantenido las luces prendidas hasta el señor Marx - y tenemos ahora que, a puro pulso, aprender a vivir sin dioses, sin mitos y sin ídolos". Yo creo que eso está bien.

Nada extraño en una obra como la de Arango que es una tremenda reflexión sobre la época. Como también decía de la suya César Vallejo: "Pues de lo que hablo 
es de lo que pasa en esta época,/ y de lo que ocurre en España y en mundo". "Palabra en el tiempo".

\section{El lenguaje en general}

Arango no solo reflexiona sobre el lenguaje de la poesía. Reflexiona sobre el lenguaje en general. Pero esta distinción entre lenguaje de la poesía y lenguaje en general quizá sea frágil. Lo digo porque para él el lenguaje "gestuno" de los sordos es una metáfora de la poesía... Pero hay que hablar de alguna manera.

Hay un poema de Cantiga sobre el cual no había parado mientes:

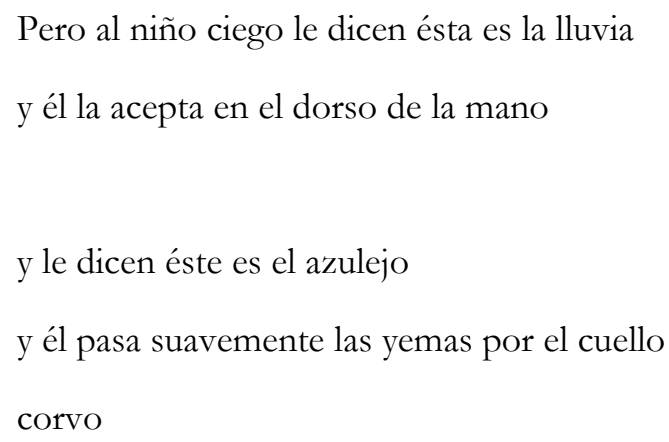

Este texto ilustra muy bien lo que decía Arango a Bonnett, ya citado: "Una vez fui a la Escuela de Ciegos y Sordomudos de Medellín y me fascinaron los niños sordos. Seguí yendo y observando, traté de aprender el lenguaje de señas o por lo menos de estudiarlo, vi cómo se hace para enseñarles, porque ellos tratan o trataban en aquel tiempo, de enseñarles a hablar". Con seguridad vio también cómo enseñaban a los niños ciegos. Y procura rescatar el momento mismo en que el niño experimenta el encuentro entre las palabras y las cosas. No soy capaz, creo, todavía, de compartir la experiencia del niño fijada acá; aunque debo decir que el poema me 
fue abierto - un poco- por mi hijo menor, quien trabajaba con niños ciegos y con base en esa experiencia hizo su trabajo para graduarse como Maestro en Artes Plásticas. Cuando supe que trabajaba en Tocar. La sombra de la nueve invisible, un intento de diálogo con el mundo ciego, le dije que Arango tenía “cosas” sobre los ciegos. Le di lo que tenía. Él puso los primeros versos de este poema en el salón donde hizo la instalación. Algún día me dijo: “-Así le enseñan a los niños ciegos”.

Arango trata de rescatar la experiencia del niño ciego. Seguramente se podrá decir que este poema muestra que el lenguaje es una convención. Se podrá remarcar que está ahí la distancia entre las palabras como rótulos generales que no distinguen entre los singulares que designan. $\mathrm{Y}$ otras cosas, como el pacto que sugiere la palabra “Apalabrar". Todo esto -Y más- lo hace juiciosamente la autora del texto "Poética

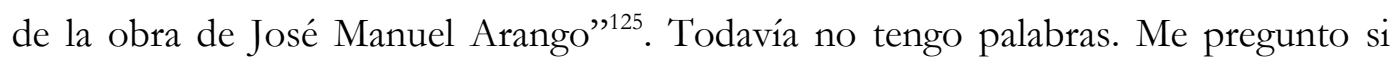
habría que enfatizar en que se trata del primer día del mundo para el niño ciego, porque ese es el énfasis de Arango; y pensar qué esconden palabras como “Apalabrar" y "aceptar" y meditar ese acto de tocar que acepta la palabra. Así mismo me inquieta cómo hay que leer un poema como este ante la aseveración de Cruz Vélez sobre Aurelio Arturo: "El tema de Palabra es el lenguaje del hombre. Este es posiblemente el primer gran poema sobre este tema escrito en nuestra lengua. Cuando lo leímos por primera vez, en Golpe de dados, quedamos asombrados de que la poesía, es decir, el lenguaje poético, pudiera esclarecer el lenguaje mismo, sacando a la luz aspectos de su ser ignorados por la filosofía del lenguaje y por las ciencias particulares del lenguaje".

125 Emma Lucía Ardila de Gutiérrez, Revista Estudios de filosofía, N 33, Universidad de Antioquia, Medellín, febrero de 2006, págs. 143 a 159. La autora señala que su "artículo parte del trabajo de investigación Poética de la obra de José Manuel Arango, para optar al título de Magíster en Filosofía” de la Universidad de Antioquia. 
“Apalabrar" hace pensar en un texto que vi por primera en una edición de 1985 de la Universidad Nacional y que Arango inexplicablemente excluyó de ediciones posteriores, diciendo que no era un poema sino que se trataba de notas que se traspapelaron: Veamos el poema con el comentario de David Jiménez:

En otros poemas, Arango no da a entender que nuestra comunicación ordinaria, no obstante su precariedad, guarda todavía en su sótano más profundo y menos iluminado, algo de aquella correspondencia. De ahí, por ejemplo, la fascinación que ha manifestado siempre por los sordiciegos. En ellos, las carencias en relación con el lenguaje hacen salir a flote, de manera negativa, ciertas evidencias de la unidad sumergida [entre las palabras y las cosas, LHV]:

Al saber lo nombres de las cosas,

dice Helen Keller, la niña sordiciega,

"se afirmaba mi parentesco con el resto del mundo".

Antes de la palabra

no había nada en ella. "No había

-dice-

ternura

ni sentimientos profundos ${ }^{126}$.

¿Qué conexión hay entre el lenguaje social y el lenguaje del poeta? Heidegger dice en "Para qué poetas" que la poesía es un soplo que no es humano ${ }^{127}$. Pero ese soplo, ese decir que no es humano, se hace con base en el decir humano. Sobre la base del soplo que pretende tal o cual objeto, se yergue el soplo por nada; partiendo del decir

${ }^{126}$ Jiménez, David, “La poesía de José Manuel Arango”, págs. 99, 100.

127 Comentando unos versos de Rilke, dice el pensador alemán, (Pág. 287):"Ese soplo más, que arriesgan los más arriesgados, no significa sólo y en primer lugar la medida apenas perceptible, por lo fugaz, de una diferencia, sino que significa de modo inmediato la palabra y la esencia del lenguaje. Esos que son un soplo más arriesgados se arriesgan al lenguaje. Son esos decidores que dicen más. Porque ese soplo más al que se arriesgan, no es sólo un decir en general, sino que tal soplo es otro soplo, otro decir distinto al decir humano. El otro soplo no pretende tal o cual objeto, sino que se trata de un soplo por nada [...] No por casualidad, en el texto del poema las palabras 'un soplo más' van seguidas de puntos suspensivos. Expresan lo callado. Los más arriesgados son los poetas...” (En: Caminos del bosque, traducción de A. Leyte y Helena Cortés, Alianza Universidad, Madrid, 1997). 
ordinario se edifica el decir extraordinario. El poeta parte del lenguaje ordinario para hacer lo suyo. Y quizá se pregunta con insistencia acerca de la incidencia de su trabajo sobre la lengua de todos. Esto parece meditarse en el poema "Una señal", dedicado a Juan José Hoyos:

Una señal una flecha tosca un pedazo de tabla clavada en un palo

Se encuentra al borde de la carretera veredal que se anuda al riñón de la montaña

Antes indicaba el camino

Ahora -torcida- apunta al desfiladero

Yo que voy a pie que no tengo prisa

Debo acaso detenerme y enderezarla

Es asunto mío será útil a alguno

Tal vez

Es un poema sobre un útil. De un útil muy especial porque es el útil que significa; entre las cosas que usamos a diario es aquel que más se acerca al lenguaje. Puedo interpretar este poema como la anécdota de alguien que no anda en la ocupación de los otros y que encuentra una indicación en el camino que se ha vuelto peligrosa, que puede inducir al abismo a un vehículo. Ya esto hace poema. Con el encanto que se encuentra siempre en la poesía de José Manuel, en la cual las cosas que vemos a diario son los temas del poetizar, dichas de la manera más natural posible. Pero tal reflexión se puede quedar corta, de entrada porque el poeta es alguien que señala, que indica, y porque el lenguaje también tiene dos planos: está el que se ocupa de las cosas diarias y el que se ocupa de nada. Y la meditación del poeta, ocupado del soplo por nada, la reflexión de él, que va a pie y no tiene prisa, de él que 
no hace la vida de los otros, se siente llevada a la pregunta de qué tiene qué hacer con ese lenguaje instrumental. Haciendo poesía se enderezan los Signos, que están en una situación que genera peligro.

Si en "Una señal" puede haber alguna duda ${ }^{128}$ en la interpretación, no la hay en “Como para el amor” (Pág. 134). Quizá esté aquí una muestra de cómo puede ayudar la poesía a enderezar los signos: reflexionando.

\author{
Desnuda \\ las piernas recogidas un tanto \\ las rodillas aparte \\ como para el amor \\ El inspector de turno \\ dice ajusta los hechos a la jerga \\ de oficio \\ el secretario \\ - con dos dedos- teclea
}

Yo

-también me he anudado mi pañuelo en la nuca-

miro el pubis picoteado"

Poema un tanto macabro que une la muerte con la exaltación de la vida: "como para el amor"... Un inspector que chambonea escribiendo. Con dos dedos escribe palabras chapuceras. No basta con estar ahí si no hay voluntad de comprender. Las palabras en el lenguaje ordinario no se ajustan a los "hechos" (En esa palabra también está la jerga), a las cosas. Las cosas se ajustan a las palabras. Vivimos

\footnotetext{
128 Como ya he dicho, la duda forma parte de la interpretación de la poesía de Arango. Como hace parte de su poesía y de su prosa. Como también hace parte de la primera la certidumbre de que este poeta es de palabra exacta.
} 
inmersos en un parloteo incesante -en una charla sin fundamento- en el que creemos que efectivamente hablamos. En eso tiene razón Heidegger. Por eso quizá sorprende el laconismo de este poeta: el que de verdad tiene contacto con las cosas tiene pocas, "contadas", palabras para decirlo. Por eso la poesía puede ser un medio para hacernos más comprensivos. Si nos tomamos el trabajo de ir a ver con nuestros propios ojos cómo andan las cosas, y tratamos de ver de verdad, seguramente vamos a comprender más.

Habría considerar sin duda otros poemas, pero creo que esto basta como indicación de la importancia de la reflexión de Arango sobre el lenguaje. El poema "Grammatici certant ${ }^{129}$ ", de Cantiga, es un curioso poema -como el pronombre que piensa Arango- ¿Tendrá algo que ver con la manía de la casta de los políticos de hoy de hablar por todos, pero siempre excluyendo?:

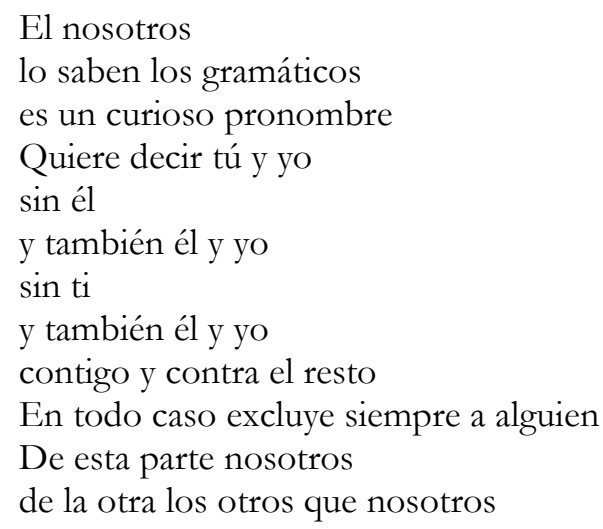

129 Poesía completa, pág. 166. 


\section{¿Una tradición de la poesía colombiana?}

En su ensayo sobre la poesía colombiana del siglo $\mathrm{XX}^{130}$, de manera insistente, se refiere este poeta y crítico a una tradición colombiana en el enfoque del lenguaje poético. Uno de los lugares dice así (págs. 67, 68):

La visión poética como vislumbre de otra lengua, más antigua y armoniosa que la del hombre moderno, en la que sea posible hablar con la naturaleza, es uno de los temas insistentes en la obra de Arango. Desde Pombo hasta Aurelio Arturo, se trata de una larga tradición que porfía en este sueño mítico, a partir del romanticismo. Pombo habla de "volver al aire primitivo" liberados del yugo del tiempo y del hábito, "para llamar las cosas por sus nombres/ otra vez como Adán". El Adán de la poesía de José Manuel Arango es el indígena que, en la lengua de los vencedores, vende pájaros en el mercado..."

Estoy de acuerdo en parte con Jiménez. No estoy de acuerdo con que solo se trate de un sueño mítico, romántico. El poema donde Arango habla -Se adivina la ironía- del inspector de turno que ajusta los hechos a la jerga del oficio es muestra clara de un empobrecimiento del lenguaje. Me parece que la búsqueda de un lenguaje cercano a las cosas es una tentativa necesaria -Puede ser eso fenomenología o poesía. Por otra parte en un país que, según los conocedores, pasó desde los 40’s a la órbita gringa, esta tendría que ser una meta necesaria. No hay sino ver la ridiculez de los nombres que ponen las personas de estratos más bajos a sus hijos, tomados de los enlatados de la televisión (Se han burlado algunas de las series nacionales más “serias” del William Guillermo o del Peter Alexander. Nuestro desarraigo es cierto). ¡Cómo no se va a dar cuenta de ello un poeta como Arango, que busco siempre arraigo!

En lo que sí parece estar atinado David Jiménez es en el hecho de que hay una tradición de reflexión sobre el lenguaje. No conozco tan bien la poesía colombiana

130 Antología de la poesía colombiana, Selección y notas bibliográficas: David Jiménez, Grupo Editorial Norma, Colección Cara y Cruz, Bogotá, 2005. En su ensayo sobre Arturo, se refiere Jiménez largamente al asunto del lenguaje. Comienza diciendo: "Es difícil encontrar en la poesía colombiana un poeta más compenetrado con la idea del poder primigenio de las palabras y la secreta armonía entre el lenguaje poético y la naturaleza que Aurelio Arturo" (“Sobre la presente antología”, pág. 44). 
como Jiménez, pero hay hechos. Arango mismo comenta el poema "Palabra"131, de Aurelio Arturo, el mismo que comenta Cruz Vélez con alegría (La única diferencia está en que este último habla de una reflexión de Arturo sobre el lenguaje. No solo el poético como dice Arango):

"Palabra" es un poema fundamental de la madurez. Una escueta -pero no por eso menos rica- meditación sobre la poesía:

en ella nos miramos

para saber quiénes somos

La palabra "fina o tosca" debe ser en todo caso forjada "con el fuego de la sangre y la suavidad de la piel de nuestras amadas". Y está

Con nosotros desde el alba

o aun antes

en el agua oscura del sueño

o en la edad de que apenas salvamos

retazos de recuerdos

de espantos

de terribles ternuras

Y es "moneda de sol". Y refleja "nuestro yo/ nuestra tribu". (¿El yo es pues un yo de la tribu según ese "profundo espejo"?) Y es "monólogo mudo" pero también diálogo. Y es

La que acuñamos

para el amor la queja"

(En Arturo también está la palabra como moneda. Palabra acuñada como una moneda que puede ser "moneda de sol/ o de plata/ o moneda falsa").

131 Aurelio Arturo y la poesía esencial", En: Aurelio Arturo. Morada al sur y otros poemas, Norma, Bogotá, 1992, págs. $56,57$. 
¿De dónde puede provenir esa reflexión sobre el lenguaje? ¿Quizá del simbolismo? Charry Lara tiene las siguientes frases ${ }^{132}$, que para mí todavía son un enigma:

Silva es uno de los primeros poetas hispanoamericanos en enfrentarse, con decisión y arrojo, al problema del lenguaje. Su poesía, aparentemente sencilla por el desgano hacia las imágenes, voces o alusiones eruditas, a las que tan dado era el gusto de la época, plantea, en primer término, la necesidad de que, en virtud de la magia de las palabras y "como las vagas formas del deseo", sea posible la expresión de las sensaciones.

¿En qué consiste este problema del lenguaje? Aquí el problema del lenguaje se puede precisar en los términos de Jiménez, quien hablando de Silva, en su antología, señala básicamente lo mismo ${ }^{133}$. El simbolismo lleva necesariamente a indagar en el lenguaje por la vía de la alquimia de las palabras. Pero esto no se precisa sino en el capítulo que sigue: la indagación de la relación entre poesía y realidad, por la vía del testimonio de poeta sobre un proceso que es legítimo llamar creación.

132 Charry Lara, Fernando, José Asunción Silva. Vida y creación, Bogotá, Nueva Biblioteca Colombiana de Cultura, Procultura, Presidencia de la República, 1985, pág. 427.

133 "Una obra poética como el Nocturno de Silva busca, quizá, antes que sorprender los asomos de una realidad invisible, pensada y tematizada en el poema, apoderarse de los efectos de encantamiento propios del ritmo verbal, más allá de la significación” (Pág. 21). 


\section{Capítulo 4. Poesía y realidad}

José Manuel Arango aprobaría, para hablar de su poesía, una fórmula aparentemente paradójica: el poema es, ante la realidad, novedad radical; pero tiene sus raíces en ella. Novedad radical. En su ensayo sobre Williams deja que este diga ${ }^{134}$ : "La poesía [...] crea un nuevo objeto, una pieza, una danza, que no es espejo ante la naturaleza sino-". El poema no es un espejo; pero la danza de palabras, la "bailarina sonámbula" que es la poesía, "debiera nacer de la vida común, de sus situaciones y experiencias. La bailarina, excepto por la breve duración de un salto, mantiene los pies en la tierra"... La poesía de Arango habla de cosas familiares, que cualquiera encuentra si echa un vistazo por ahí, cosas de la vida cotidiana; y muestra esta vida cotidiana con tal cercanía y plasticidad que hay quienes hablan de que “imagina murales", de que sus poemas son "instantáneas" o "radiografías". Un verso como "en la carnicería cuelga el tronco de la res desollada", hace decir a muchos: “-Rembrandt". Poemas que son "cuadros mondos".

No hay más remedio que comenzar por acá ${ }^{135}$, señalando lo que califico como paradoja aparente e intentar ventilarla, y aprestarse a hacer frente a otras paradojas reales o fingidas.

134 "La poesía de William Carlos Williams", en: Whitman, Dickinson, Williams. Tres poetas norteamericanos, Norma, Bogotá, 1991, pág. 57.

${ }^{135}$ Hay que poner de presente este punto al comienzo de una reflexión sobre la relación entre poesía y realidad. Que el tema es importante lo ratifica un autor como el discípulo de Heidegger, Hans-Georg Gadamer: "Porque poetizar significa que la palabra de la poesía se confirma a sí misma y que no puede ser confirmada por nada más. En este sentido es sin duda erróneo, aunque ocurra a menudo, si se quiere llegar desde fuera a la palabra poética, buscando relaciones con la realidad para entender, por ejemplo, la génesis de una obra poética, o si se pretende medir su enunciación desde el saber de la ciencia que calificaría como verdadero aquello que la palabra poética designa. Es cierto que la poesía refleja casi siempre una realidad que también puede ser objeto de conocimiento científico. Mas el hecho de que la palabra se confirme a sí misma y no necesite ser reafirmada desde otro lugar, y que incluso ni siquiera lo admita, esto constituye la Aletheia (que Heidegger tradujo por desocultamiento), lo que significa más que calificar como correcto cualquier tipo de conocimiento" (Subr. LHV). "Pensamiento y poesía en Heidegger y Hölderlin", En: Los caminos de Heidegger, trad. Ángela Ackermann, Herder, Barcelona, 2002, pág. 376. 
No pretendo en este capítulo otra cosa que estudiar dos fórmulas de Arango: la poesía nace de "una reflexión sobre lo que somos" o de una "respuesta a una experiencia personal, dolorosa o alegre". En segundo lugar, busco indicar lo que puede ser una corriente en la poesía colombiana, en la que estarían nombres como Silva, Arturo, Mutis -Quizá Echavarría, Mario Rivero, X-, y el mismo Arango.

Las estrategias para adelantar el primero de los propósitos requieren una explicitación. Indicaré lo que Arango llama "raíces" de su poesía; y, dado que es una ayuda para determinar el sentido de su obra, señalaré lo que dice Arango sobre lo que la crítica llama influencias: él habla de los poetas que "más quiere”, de aquellos con los cuales tiene afinidades. Finalmente, haré una primera exploración de la reiterada palabra "experiencia". Y de la respuesta a ella: "la reflexión del ser todo de carne y hueso".

\section{...una reflexión sobre lo que somos}

Hay unas formulaciones similares a esta. En la entrevista concedida a Babel ${ }^{136}$ :

Babel: En Signos lo erótico es el tema presente, en Cantiga aparece la denuncia social. ¿La palabra denuncia está bien?

J.M.A: Yo no diría denuncia. Quería hacer una reflexión sobre la violencia. El libro se escribe cuando la situación de este país se está poniendo horrible. (Subr. LHV)

Babel: En Montañas hay un poema: "Nada en ellas es blando/No son estas, por cierto,/ las formas de una tierra/llana y amable". ¿Es la dureza de esta tierra, de este país?

J.M.A: Estamos en el país más violento del mundo.

136 "Conversatorio con José Manuel Arango. El excesivo pudor”, Babel, N 4, Medellín, Diciembre de 1996 - Marzo de 1997, pág. 21. 
Al final de la entrevista de Bonnett ${ }^{137}$ dice que la escritura poética es "un modo de reflexionar sobre asuntos que inquietan, de tratar de ponerse en claro uno mismo".

Como se ve, Arango reitera la palabra reflexión. Esta aparece además en el texto tantas veces citado de su "Nota": "Quizá el poema nazca de la exploración de una circunstancia compartida, o como respuesta a una experiencia personal, dolorosa o alegre. Unas contadas palabras que serán reflexión, no del intelecto solamente, sino del ser todo de carne y hueso". El uso de la palabra en cuestión creo que choca contra lo que el sentido común entiende por poesía, a la que concibe más como un vagabundeo imaginativo. Pero está empleada con toda deliberación. Es más: cuando, en el ensayo sobre Arturo, dice que el poeta es algo así como un adolescente retardado, da la razón: el adolescente, que, como cualquier ser humano, no puede pensar ni imaginar la muerte, sí la experimenta, asiste a su propia muerte, y es esta asistencia lo que permite que en él se dé el desdoblamiento que permite la reflexión. Ahora bien, este volverse sobre uno mismo ${ }^{138}$ es volcarse sobre un uno mismo vaciado para dejar que lleguen las presencias, como hemos visto que lo reitera María Zambrano.

\section{Las raíces de la poesía de Arango}

Como ya dije, la palabra raíz tiene un secreto para mí. Si uno hace caso de la manera como ayuda a leer Zambrano la palabra raíz, habría que decir que hablamos

\footnotetext{
137 "Entrevista con José Manuel Arango", en: José Manuel Arango, La tierra de nadie del sueño. Poemas póstumos, Ediciones DesHora Intergraf, Medellín, 2002, pág. 72.

${ }^{138}$ En la nota de traductor cxiv dice Jorge Eduardo Rivera (Ser y tiempo, trad., prólogo y notas de Jorge Eduardo Rivera, Editorial Universitaria, Santiago de Chile, 1998. Versión pdf, pág. 434), sobre esta palabra fundamental de Ser y tiempo: "Yo no sé si siempre el uso del "uno" en castellano es impersonal. En el célebre verso de Miguel Hernández: 'TTanto penar para morirse uno!', me parece que el uno tiene un sentido distinto, difícil de precisar, pero ciertamente no impersonal. Casi se diría que en este caso el uno es lo más íntimo y personal de todo”.
} 
ahora de la necesidad de la poesía de Arango (Perdón: cambiando una imagen, "que vale más que mil palabras", por una palabra abstracta. Pero son inevitables estos juegos). Y ello quizá explicaría que haya comenzado la poética de su "Nota" con una frase desconcertante en un poeta: "Es difícil saber hoy lo que debe ser la poesía" (Subr. LHV). Pero ya he mostrado cuántas frases "raras" tiene este poeta. ¿Qué necesidad ve, entonces, Arango en la poesía? ¿Quizá nuestro desarraigo? Hay un poema ${ }^{139}$ de Montañas, fácil de leer como un poema simbolista (He hecho la prueba comentándolo con algún lector muy cultivado, y fue este quien hizo una lectura simbólica: vio en el texto algo así como la situación del hombre hoy -Comento esto también para insistir en que con el Arango desde Cantiga nunca está uno seguro en la interpretación-).

\author{
Estas raíces \\ -en parte cercenadas- \\ del pino \\ que un tajo de la montaña \\ al borde \\ del camino dejó desnudas
}

Estas raíces
obstinadas y corvas
que se aferran
como uñas
al suelo

Las raíces se aferran como uñas. El árbol parece no querer dejarse ir abajo con la montaña erosionada. Se aferra. Furia. Hay una furia que aparece en el lenguaje. En “Cosas a un tiempo familiares y ajenas", me pregunté: “¿Por qué parece que, situadas

139 "Pino", en: Poesía completa, pág. 203. 
en el poema, son tajantes, secas, las palabras cercenadas y tajo?, ¿por qué nos sorprende en él la dureza del sonido de aferran?, ¿por qué las palabras cercenadas y tajo, por una parte, y obstinadas y aferran, por otra, parecen "mirarse", afirmarse y prolongarse entre sí?" He escrito reiteradamente sobre este poema, y solo ahora me doy cuenta de que hay una clara licencia para la lectura simbolista: la comparación de raíces con uñas da pie para que las metamorfosis propias de la poesía simbolista se desaten. Sí: la furia de la vida que está amenazada es algo experimentado con intensidad por este poeta. Pero ¿qué dice él de las raíces de su poesía?

Piedad Bonnett: A pesar del mucho tiempo que pasaste fuera de Antioquia, yo creo que tú eres muy antioqueño. ¿Tú sientes que en tu obra hay algo que se pueda relacionar con la "antioqueñidad"?

José Manuel Arango: La “antioqueñidad”... Bueno, sí. Uno es de alguna parte. Además estoy convencido de que uno debe ser de alguna parte, de que hay que tener raíces. He tratado siempre de que lo que escribo parta de experiencias muy concretas. En este sentido, para mí son muy importantes no sólo las Montañas, sino los árboles con sus nombres, los lugares con los que estamos familiarizados, los usos y modos de ser y de hablar. Lo que ha pasado con la "antioqueñidad" es que se ha convertido en una caricatura, en un estereotipo chauvinista. Pero hay otra cosa que encuentras en Carrasquilla, en Fernando González, en uno de los poetas que yo más quiero, Epifanio Mejía, que fue el primero que le cantó a estas montañas. Yo diría que en muchos otros: escritores, artistas, que son ejemplares de un tipo humano distinto al del antioqueño avivato, que por desgracia es el más común. Ellos han querido hablar desde aquí, desde sus raíces. Fernando González trató de pensar desde aquí, desde su circunstancia, trató de pensarnos desde nosotros mismos.

P.B.: ¿Tú encontrarías palabras para calificar esa "antioqueñidad" más profunda, sus elementos diferenciadores?

J.M.A.: Cómo no. No es eso que llaman el liderazgo antioqueño, ni es la apología ni los símbolos baratos. De todo eso se burló ya Carrasquilla en sus cuentos y novelas. Es más bien la reflexión sobre lo que somos. ¿Qué hicieron Carrasquilla y Fernando González? Mostrar lo que es Antioquia. Mostrar, en primer lugar, cuáles con las carencias y las lacras que tenemos, las orfandades.

Pero yo creo que si hay esa raíz antioqueña en lo mío, también hay otra del altiplano. Ciertas experiencias de Boyacá son para mí muy entrañables: las de las lagunas, los trigales, los modos de ser, el hecho de que Boyacá sea una tierra del agua (Subr. y negrillas, LHV) ${ }^{140}$.

140 Obra citada, págs. 55 y 56 
¡Cómo remarca Arango la expresión “reflexión sobre lo que somos” y de qué manera la acerca a la palabra experiencia! Además es notable que se muestre atento a las carencias y lacras. A todo lo que está amenazado: el árbol, la montaña erosionada, el pájaro; y a las debilidades físicas y morales de los hombres: va a ver al ciego de la plaza para ver si sigue vivo y encuentra en un gesto casi imperceptible cómo también se aferra a la vida; y se indigna ante las debilidades morales. Seguro que, como dijo mi director de tesis, está atento a cuanto vuelve a un hombre "mueca de sí mismo". Por otra parte, los rasgos espirituales del viejo González tal vez dicen mejor lo que tratamos de afirmar, en ese poema donde también se insinúa una de nuestras grandes lacras, la violencia:

\section{4}

Y todo lo que ven es asunto de su lento monólogo,

todo casa en la larga meditación que lo ocupa.

En ella cada cosa tiene un lugar y un sentido.

Es una pregunta, una señal.

8

Bah, puro misticismo, religión pura.

Prédica de cura viejo, dijimos.

¿Qué podría enseñarnos? Preguntó nuestra desconfianza.

9

Vida, diosa de los ojos maliciosos

10

Nos pensó. Tuvo ojos para ver nuestro entorno.

Conocía esta tierra.

Una tierra como útero herido por el partero con la uña.

Ahora bien: ¿qué tanto pesan estas "raíces" en la escogencia de sus poetas? 


\section{... uno llega a encontrar una voz [...] por afinidad con otros poetas}

Es preciso escoger unos pocos poetas para pensar esto. La inspección de la obra de Arango hecha por David Jiménez encuentra muchos "parentescos" -Y como dije no es exhaustiva-. Su lista incluye a Hölderlin, Rilke, Trakl, Paz, Lezama, Gaitán Durán, Williams, Fernando González, Borges, Wallace Stevens, el imaginario español y antioqueño de la muerte (Contrarreforma, Carrasquilla, Echavarría, X), Anacreonte, Dickinson. Al final de su texto resume Jiménez ${ }^{141}$ :

Un poeta como José Manuel Arango hace de su obra un punto de cita de poetas antiguos y modernos, de tres o cuatro lenguas diferentes, cercanos o distantes en el tiempo y en espacio.

"Tal vez uno llega a encontrar una voz o un tono, si es que de veras los encuentra, por afinidad con otros poetas”. En alguna parte habla además Arango de la importancia para él de la poesía oriental: Han-Shan, el Zen, el haikú. Ahora bien, hay varios poetas que Arango "quiere más". Lo cual quiere decir que se busca en ellos y en ellos se reconoce ${ }^{142}$. Sobre algunos de estos escribió.

Sin duda, William Carlos Williams le es afín entre otras cosas por las raíces. En las pocas páginas del ensayo ya mencionado, está cuatro o cinco veces la palabra "raíz" y una asociada: "arraiga". Un par de veces el uso de la palabra tiene que ver con Eliot $^{143}$ (Sobre él dice más o menos lo mismo que me dijo a mî):

Una poesía que arraiga en lo inmediato, en lo cotidiano. Williams comparte la desconfianza de Whitman por la cultura académica y el verso clásico. Su reproche a Eliot y aun a Pound es que perdieron contacto con sus raíces, que se fueron a Inglaterra o a Provenza, que son demasiado "cultos".

\footnotetext{
141 “La poesía de José Manuel Arango", pág. 153.

142 Poetas en los que se reconoce, en los cuales ve lo "propio". Lo dice él mismo en el poema de González, con unos versos que me retumban en la memoria, porque eso es para mí Arango: "Y esa forma suya de hablar, con vocablos redondos, duros./ Uno sabe: esto es mío. Se reconoce./ Usó para pensarnos el dialecto que hablamos" (Pág. 268).

143 “La poesía de William Carlos Williams", págs. 53, 54, 58, 63.
} 
La polémica con Eliot es bien significativa. Eliot era el enemigo. Lo que no le gustaba era ciertamente la falta de raíces, que se hubiera ido a Inglaterra, que se hubiera reincorporado a la cultura europea, que hubiera regresado al pentámetro yámbico y a la religión anglicana, que hubiera abandonado las ideas de libertad a las que Williams, en cambio, permaneció fiel.

La afinidad con la pintura es uno de los caracteres que primero resaltan en la poesía de Williams. Y no principalmente por sus referencias -frecuentes- a pintores, sino porque hay en ella algo de raíz, algo que viene de la concepción misma de la escritura, que la hace pictórica. (Subr. LHV)

Como otros rasgos de la obra de Williams, los que aquí menciona se le pueden aplicar a Arango. En el médico se reconoce. Como se reconoce en Arturo. Otro poeta sobre el que escribió un ensayo ${ }^{144}$ que "no tiene desperdicio":

El mundo mágico y encantado de Arturo no es sin embargo irreal. Es el que conoció de niño en el sur, tan de aquí, tan nuestro. Tropical y medio salvaje, con nodrizas negras y tambores que suenan "a lo lejos", "en la noche de lentos párpados morados", y cuyo sonido llega "atravesando valles y valles de silencio. [...] Porque está arraigado en su tierra, en el país y los países de Colombia, puede decir: "por mi canción conocerás mi valle". (Subr. LHV)

Indudablemente era la palabra raíces una de las palabras favoritas de Arango. Arango, a quien Bonnett, al comienzo de su entrevista, dice que asocia con un árbol de invierno, nudoso, escueto, frágil y recio a la vez...

Otro par de poetas a los que uno puede asegurar que Arango "quería más” eran Vallejo y Machado. Un Machado que en el poema "Del camino", ya comentado en el capítulo anterior, está asociado a la reflexión sobre esta época en que ya, para muchos, no hay sentidos trascendentales. Lo quería por esto y además por el tono de quien habla en voz baja, como Silva. O Williams, Dickinson, "que no declaman o predican", sino que hablan... (Hay que decir que estos dos norteamericanos tenían algo de sangre hispanoamericana).

144 “Aurelio Arturo y la poesía esencial”, págs. 55, 56. 
En la conversación con Bonnett habló de varios poetas. En sus afirmaciones está el arraigo aunque no esté expresamente la palabra. Así en el caso de Vallejo ${ }^{145}$ :

...ese apego a lo nuestro, por ejemplo, ese hablar de su "burro peruano en el Perú (perdonen la tristeza)". Su "terredad", para usar la expresión de Eugenio Montejo. A lo mejor Vallejo ha influido en todos mucho más de lo que se cree.

José Asunción Silva merece una mención aparte. Creo que muchos lo siguen viendo como el simbolista afrancesado (Aunque Charry -También Jiménez Panesso- insiste en estudiar su relación directa con Poe), como un dandy de segunda, caricaturesco: “José Presunción”, uno de los apodos que le pusieron sus contemporáneos. Arango lo quiere por la música, por el tono. Pero también porque entendió la época. Y sospecho que también por ese apego a lo nuestro. Fernando Charry Lara ${ }^{146}$ destaca ese rasgo así:

A varios poetas hispanoamericanos vincula también la lección de José Asunción Silva en lo que en ella existe de transparencia de la atmósfera física y espiritual de un país. Silva es uno de los poetas más colombianos que puedan pensarse. No sólo el "Nocturno" y otros poemas son la Sabana de Bogotá147, o la ciudad, sino que en casi todos ellos se infiltra una asombrosa versión de nuestro ambiente. Juan Ramón Jiménez intuyó con notable acierto esta virtud poética y llama a Silva, en oposición a ciertos exotistas de esa época, vueltos hacia Europa, la Biblia o el desierto, un "modernista natural". Lo vernáculo o circundante no le desmerece, sino, por el contrario, da visible sustento a su imaginación.

Finalmente, Álvaro Mutis. Hubo tiempo para que en vida dieran los dos muestras de mutua admiración. Mutis dijo alguna vez que Arango era el poeta colombiano de la actualidad que más le interesaba. Cuando le dieron el premio de poesía de la Universidad de Antioquia, puso como condición de que en la ceremonia estuviera Arango. Este lo consideraba su amigo; y Mutis es uno de los pocos poetas de quien Arango puso epígrafes: en Montañas. Para mí ha sido muy, muy importante Mutis,

\footnotetext{
145 Obra citada, pág. 67.

146 "Divagación sobre Silva”, pág. 427.

147 En alguno de sus textos sobre Silva, precisa Sanín Cano el lugar de la sabana de Bogotá que proporcionó la geografía del "Nocturno": Mejor: ¿la geografía que proporcionó la experiencia de la que nació el poema?
} 
pero hay algo que no me gusta. Supongo que son sus opiniones generalizadoras, un poco pueriles; e incluso algún tiempo pensé que era su ritmo o cierta suntuosidad (Ahora ya no sé). En mi conversación se lo comenté a Arango, y esta fue una de las pocas discrepancias que tuvimos. Él se refirió de una manera hermosa al ritmo de Mutis, con una metáfora natural, como si la poesía de Mutis tuviera algo que este quería, es decir, que fuera voz de las cosas. Ritmo caudal, voz de creciente:

Me parece que ese ritmo caudal juega muy bien con sus ríos crecidos del trópico, con esa desmesura de Maqroll, y detrás de eso hay una visión del mundo que es muy lúcida, muy bella.

Una de las pocas ocasiones en la que tuvo Arango que contestar de manera ceñida por su relación con los poetas colombianos, fue en la entrevista con el cubano Víctor Rodríguez Núñez ${ }^{148}$, en la cual están algunas de las frases más lúcidas, y chocantes, de Arango:

VRN: Si ineludiblemente tuvieras que hacer una antología de diez poetas colombianos. ¿A quiénes incluirías?

JMA: A ver: los poetas colombianos que más he frecuentado... Comencemos por los románticos. Epifanio Mejía, un poeta de estas montañas, de verso muy delicado. Rafael Pombo, un puñado de poemas en una obra voluminosa, algunos de ellos para niños que los siguen leyendo y disfrutando. Silva, desde luego. Porfirio Barba-Jacob, algún momento de León de Greiff. Aurelio Arturo, siempre: la música asordinada y la visión mágica. Jorge Gaitán Durán, Rogelio Echavarría y Álvaro Mutis, inevitablemente. Jaime Jaramillo Escobar... Bueno, ya están los diez y todos anteriores a nuestra generación, excepto Jaramillo Escobar. Como quien dice, nuestra herencia. Sí, quizás la región resulte indispensable en la propia formación. En todo caso, una antología así resultaría algo muy personal y excluiría nombres injustamente.

A mí me gustaría ahora poder preguntarle expresamente por El tuerto, como llamamos en Colombia al estrábico Luis Carlos López. Uno pensaría que el realismo de este, la búsqueda de la palabra nuestra ceñida a las cosas de alguno de sus

148 La poesía es eficaz, nos cambia”, Magazín dominical, El Espectador, № 632, 25 de junio de 1995, pág. 11. 
momentos, cierto talante crítico, la precisión en lo individual, darían para algún afecto. Quizá lo distancien de él los aspavientos metafísicos de Arango, que yo comparto. Arango es por otra parte un poeta serio, que se sabe anacrónico; el cartagenero no comparte este rasgo... Pero alguna cercanía se puede tejer con el implacable cartagenero de chismes de parroquia $^{149}$ :

\author{
Se murió Casimiro, el campanero \\ de la iglesia rural, y esta mañana \\ lo llevaron al último agujero, \\ con tres o cuatro dobles de campana.
}

Se lo llevaron bajo un aguacero,
definitivamente, y quedó Juana,
su sobrina, sin sol y sin alero,
y tan hermosa como casquivana.

Y quién podrá decir que Casimiro

no apuró, sorbo a sorbo, entre un suspiro

y otro suspiro un cáliz de amargura.

¡Conociendo la lengua viperina

de las devotas, conociendo al cura

y conociendo tanto a su sobrina!

\title{
El poema, respuesta a una experiencia personal
}

Creo que hay suficientes testimonios. Arango concibe la poesía como reflexión sobre lo que somos. Quizá los poetas que más quiere se identifican con él en esa

149 Tomado de William Ospina, "Luis Carlos López", en: Por los países de Colombia, Eafit, Medellín, 2002, págs. 146, 147. 
manera de entender "el oficio". Pero, ¿no le coloca a la poesía un fin exterior a sí misma, en la época de la autonomía artística? Y ante todo, ¿cómo es esa reflexión del ser todo de carne y hueso? Creo que, para intentar comprender esto, hay que ir a los testimonios que proporciona sobre su proceso creativo y, para ser fieles a la cautela, tener constantemente presente su poesía. Acudir a testimonios de autoobservación, o de reflexión, del proceso creativo y a la meditación de sus poemas ${ }^{150}$. El hilo conductor de esta exploración debe ser la frase que guía este aparte, cuyo contexto es el siguiente: "Quizá el poema nazca de la exploración de una circunstancia compartida, o como respuesta a una experiencia personal, dolorosa o alegre" (Subr. LHV).

La palabra experiencia, dice Ferrater Mora, es muy vaga. A fuerza de tener multiplicidad de sentidos. ¿En qué sentido la usa Arango? Una primera precisión la da la observación, fácilmente comprobable, de que en la frase de Arango hay dos momentos: la experiencia y su respuesta. El poema no es solo la experiencia sino también la respuesta a ella. La experiencia es la base. Creo que la noción de experiencia nos puede ser clarificada por un poema que tematizo largamente en José Manuel Arango. Poética y poesía. Está recogido en la sección "Otros poemas” de Poesía completa (Pág. 260):

\author{
Estas cosas que la sorpresa \\ de una mañana clara \\ -a veces una repentina zozobra- \\ nos ilumina, nos devuelve.
}

\footnotetext{
${ }^{150}$ Esta consideración tendrá permanentemente en cuenta las poéticas de Arango, estudiadas en "Las reflexiones de José Manuel Arango sobre la poesía”, el cual acaba de ser reseñado por Juan Gustavo Cobo Borda: "Una década de poesía: 1999-2008”, Boletín Cultural y Bibliográfico, Banco de la República (www.coboborda.org). Me referiré insistentemente al poema "La bailarina sonámbula", cuya conexión con la manera de concebir la poesía Paul Valéry aparece en mi entrevista.
} 
El pichón emplumado
que asoma la cabeza
en el palomar, la neblina
que se enreda en las ramas de los pimientos.

Cosas a un tiempo familiares y ajenas

como la risa del hermano

vuelto a encontrar ya viejo.

Resumo aquí mi interpretación de este poema que dice tantas cosas en tan pocas líneas. En estos once versos están los afectos (repentina zozobra, sorpresa...-asombro-) que abren los estados poéticos, la iluminación que en estos se produce, la naturaleza como una de las puertas que lleva a esos estados; la precisión del carácter a la vez ajeno y familiar de las cosas abiertas, devueltas porque están en la vida diaria olvidadas e invisibles como las Montañas del poema que cierra el libro que lleva ese título. La zozobra es repentina, instantánea, como es súbito el trueno de uno de los poemas de Este lugar de la noche.

El poema consigna una "experiencia", "un momento de esos en los que parece que [uno] despierta y [...] comprende algo", como le dice Arango a Bonnett, con palabras en las que uno oye las coplas de Jorge Manrique. Se aviva el "seso" en un momento de iluminación. Lo mismo que Arango dijo a Bonnett, lo señaló para la entrevista de Babel-pero agregó algo-: “Yo más bien trato de fijar ciertos momentos de la experiencia ordinaria ${ }^{151}$, personal pero compatible por todos. Se podrían llamar ‘iluminaciones’ tal vez. En lo más común se muestra a veces lo otro [...] puntos de

\footnotetext{
${ }^{151}$ Como veremos más adelante, con el uso de la palabra Arango señala un punto de partida que se opone en particular a desarrollar la tarea poética a partir de un tópico. En el ensayo sobre Echavarría señala: "Otro de los asuntos de la poesía de Rogelio Echavarría es la soledad. No se trata, claro, de la soledad como tópico sino de la experiencia de la soledad" "“Una poesía para nuestro tiempo", pág. 160). La palabra experiencia es de tal modo reiterada entre los críticos, poetas y filósofos que merecería un estudio aparte.
} 
contacto entre lo cotidiano y lo otro" (Pág. 21). ¿Qué pasa con la risa del hermano vuelto a encontrar ya viejo? Asoma lo otro de la vida en ese pichón emplumado: asoma la muerte- ¿De ahí la "zozobra", la angustia?-.

"Uno de esos momentos en los que parece que uno despierta y comprende algo". Dije que este poema consigna una experiencia. Pero entendamos que, si es poema, es experiencia y respuesta. Si hay sorpresa, uno queda boquiabierto, sin palabras. La experiencia es eso. Esto nos los ayudan a clarificar Heidegger y Ferrater. En el texto ya citado de Gutiérrez A. ("Filosofía y poesía. Vecindad como cercanía y diferencia", pág. 31): "Y puesto que hacer una experiencia con algo significa, según Heidegger, 'que algo nos acaezca, nos alcance, se apodere de nosotros y nos transforme'..." Claro: tenemos que dejarnos afectar, para dar lugar a la transformación, que es transformación en la comprensión, la cual no tiene que ser temática. Pero tiene la posibilidad de serlo. Cuando esto sucede la comprensión se despliega en la interpretación, en el sentido estricto que la palabra hermenéutica toma en Sery tiempo, donde deja de ser teoría de la interpretación de textos sagrados y literarios, y se convierte en algo propio de la ocupación en la vida cotidiana.

En este primer momento estamos sobrecogidos, tomados por el asombro. Uno no se detiene a tomar conciencia. Eso viene luego... O no viene. Pero la transformación está hecha. Es un momento antepredicativo, como dice Ferrater, proponiendo los dos primeros sentidos de la palabra experiencia ${ }^{152}$ :

El término "experiencia" se usa en varios sentidos: (1) La aprehensión por un sujeto de una realidad, una forma de ser, un modo de hacer, una manera de vivir, etc. La experiencia es entonces un modo de conocer algo inmediatamente antes de todo juicio formulado sobre lo aprehendido. (2) La aprehensión sensible de la realidad externa. Se dice entonces que tal realidad se da por medio de la experiencia, también

${ }^{152}$ Ferrater Mora, José, Diccionario de filosofía. pdf, pág. 605. 
por lo común antes de toda reflexión - y, como diría Husserl, prepredicativamente.

La experiencia es anterior a la reflexión (¿Ya se habrá constituido un sujeto? ¡Habrá tenido tiempo?), la cual sin embargo, en el buen poema, no elimina el asombro: hay que volver al lector un inspirado, pedía Valéry. Metafísica de poeta de Machado: "las preguntas radicales guardan aún el estremecimiento de la admiración originaria de que han surgido y las respuestas de que se dispone no gozan todavía del estatuto teórico de las 'ideas', 'sino aquel otro de las creencias' con que cuenta uno, al decir de Ortega, en que se apoya uno para vivir..." No hay que descartar las ideas: solo darles un soporte y no dejar que se independicen demasiado, porque deben seguir manteniendo el vínculo con la situación de la que nacen y en la que palpitan ${ }^{153}$. El brotar de la idea desde la cosas, hace pensar en un fragmento de carta de Silva ya citado: esforzarse “por comprender más, por deshacer preconcebidos”. ¿Qué pasa con el preconcebido en poesía: “echa a perder el poema” como dice Jiménez P., en “La poesía de José Manuel Arango" (pág. 99). Y parece coger en falta a Arango, aunque más o menos lo disculpa:

Tal vez en otra lengua pueda decirse

la palabra

como una moneda antigua, hermosa e inútil

[...]los tres versos arriba transcritos, que pertenecen al poema frentes de cuero, rocas, son una expresión bella y justa de una idea más o menos preconcebida, si bien el resto del poema es magnífico...

\footnotetext{
${ }^{153}$ De los médicos Benn y Williams, afirma Arango en el ensayo sobre este último (Pág. 55): “Dos poetas distintos o más bien contrarios. Cada uno parece la negación del otro. Por un lado la negación y por el otro la afirmación, hecha de algo así como la negación de la negación. Y no obstante, por debajo de la diversidad, uno no puede menos que encontrar una estética común en lo esencial. El rigor, la sobriedad, cierta oscuridad necesaria, el cuidado del ritmo. Y una objetividad como de pintores. Los poemas de Benn no son discurso, son cuadros mondos. El discurso nace de la situación, es una reflexión sobre ella. Y Williams dice, es uno de los axiomas de su estética, que la idea debe estar siempre en las cosas" (Subr. LHV, Págs. 55, 56
} 
Finalmente, hay que destacar en la palabra experiencia el uso corriente: como dice Moliner, hacer una experiencia es hacer algo por uno mismo. Para quien parte de la experiencia no hay dogma que valga: tiene que ir a hacer la prueba por sí mismo. Seguramente las verdades de quien parte de dogmas son copiosas y sustraídas de incertidumbres... Pero lo que se gana en abundancia se pierde en riqueza y en compromiso. No es este el caso de poetas como Silva o Arango: "-A ver, déjeme comprobar por mí mismo, déjeme hacer la prueba, y, ahora sí, pensemos”, parecen decirnos. Pobreza del conocimiento, ignorancia oceánica, claro; pero así es la cosa... Somos seres humanos, finitos.

\section{...ese vuelo de palabras / es la poesía}

Estos versos están colocados casi al final del poema de Arturo por el que se entusiasma tanto Danilo Cruz Vélez, el mismo que, hemos visto, Arango tematiza largamente. Un fragmento del mismo ${ }^{154}$ (fragmento de ese fragmento que es el poema, que no lleva mayúsculas ni puntuación):

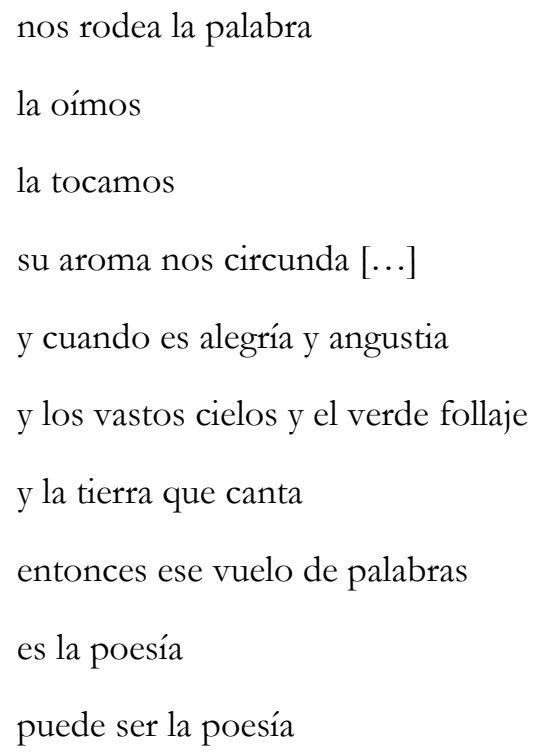

154 Golpe de dados. Revista de poesía, Nº 1, Vol. 1, Bogotá, enero-febrero de 1973, págs. 4 y 5. 
Estos versos dicen ya lo que es la respuesta a la experiencia, la reflexión. Eso nos lo ayuda a precisar, con la misma palabra, María Zambrano ${ }^{155}$ :

Asombrado y disperso es el corazón del poeta -"mi corazón latía, atónito y disperso"- . No cabe duda de que este primer momento de asombro se prolonga mucho en el poeta, pero no nos engañemos creyendo que es su estado permanente del que no puede salir. No, la poesía tiene también su vuelo; tiene también su unidad, su trasmundo. De no tener vuelo el poeta, no habría poesía, no habría palabra. Toda palabra requiere un alejamiento de la realidad a la que se refiere... (Subr. LHV)

Tras el momento de asombro, en el que algo llama la atención, conmueve, viene la reflexión. Es el del asombro un momento en el que el poeta no sabe aún "qué rebaño lo anda buscando", como dice en un reportaje el cantautor Atahualpa Yupanqui. Parece que uno despierta y comprende algo, pero no sabe aún qué es lo comprendido. El pichón emplumado simplemente hace saber que tiene "algo" que decir y eso se denuncia en el poeta con -digamos así- con un "clic" "156. Ahora, tras el asombro, tendrán que venir las palabras, el vuelo de las palabras. O como dice José Manuel en "La bailarina sonámbula": "Pero no es un vuelo. La bailarina no vuela. Es casi como si fuera a volar, a despegarse del suelo, pero el gesto es a medias irónico, no trata de engañar, no sugiere ninguna elevación fingida”. ¿Les lleva la contraria a Arturo y a Zambrano? ¿Y al tiempo les da algo de razón? Sea como fuere, vuelo o "casi-como-sí", hay que darle algo de respaldo a esta afirmación, y para ello lo más conveniente es ver el testimonio de Arango sobre su proceso creativo. Vuelvo a decir de otra manera lo que comprendo hasta aquí: el poeta ha pasado por un instante en el que la mirada, traspasada por el sueño, la sombra, la muerte, el silencio, se ha asombrado. Pero ahora viene el vuelo; hay que arrancarse de ese estado: "El

\footnotetext{
155 Filosofía y poesía, pág. 21.

156 “Un rostro, un gesto, un tema musical, escribe Mutis en 'Sonata', 'vuelven un día a visitarte', llaman de otro tiempo y quizá estén a punto de decir 'con unos labios sin voz, la palabra que tal vez iba a salvarte'. Son anclas que revuelven las profundidades sin que el yo lo advierta del todo. Hay algo que espera emboscado y se sabe 'por cierto sordo dolor que cierra el pecho'. En: David Jiménez, Antología de la poesía colombiana, pág. 52 (Subr. LHV).
} 
baile comienza en el sueño y en cierto modo se mantiene dentro de él. Pero es también más que el sueño y se arranca de él”. Viene la reflexión, un poco sonámbula, ella. ¿En qué consiste? Sobre su proceso de creación le dijo Arango a Piedad Bonnett (Págs. 70, 71) ${ }^{157}$ :

Silva decía que "uno no hace los versos, los versos se hacen dentro de uno y salen". Yo sospecho que ésa es la experiencia que tienen todos los poetas. Dejan que los versos se vayan haciendo poco a poco en la cabeza, o en el oído interno o qué sabe uno dónde, hasta que el poema está maduro y entonces lo pasan al papel.

El proceso se podría comparar al crecimiento de una planta. En mi caso la semilla es una frase, algunas palabras que empiezan a dar vueltas como sucede a veces con una frase de una canción. La diferencia está en que la canción está por hacerse. Esa frase debe tener cierta música para que le dé ritmo al poema, a otras palabras que van a disponerse alrededor de ella y a completarla. Hay poetas que dicen que parten de un ritmo, lo más común es que lo digan los que escriben en metros regulares. Por ejemplo, a Giovanni Quessep le oí decir alguna vez que primero tiene en el oído un ritmo y de ahí nace el poema. Pero también cuando se escribe en formas menos regulares, el comienzo, la semilla es una frase musical. Aun cuando no se anteponga la música a todo lo demás, como hacían los simbolistas, creo que es esencial para la poesía.

Y la frase debe tener también intensidad. Debe hablar de una experiencia, de alguna situación o emoción particular. Muchas veces contiene una imagen, una imagen visual por ejemplo. Sólo que tiene que ser una imagen dada ya en palabras. Después esa semilla, ese tema, va desarrollándose y modulándose. Si se logra un desarrollo, un crecimiento, se da el poema. Y cada uno toma su propio tiempo para formarse. Algunos, sobre todo si son muy cortos, nacen casi completos. Otros se demoran en crecer, a veces años. En cierto momento se puede sentir que hay allí un poema (aunque uno no debería llamar poema a lo que escribe, texto sería menos pretencioso), o le parece que hay allí algo completo, redondo, como un pequeño organismo. Entonces lo escribe. Y lo guarda un tiempo para que lo corrijan los duendes.

Cuando después de un tiempo vuelve a leerlo, la mayoría de las veces encuentra que allí no había nada. Pero otras pocas le sigue pareciendo todavía que sí hay algo, algo que respira, como quería Emily Dickinson. Naturalmente uno nunca puede estar seguro. La primera impresión frente a un texto propio, cuando todavía no ha pasado el entusiasmo con que se escribió, resulta casi siempre un engaño, un espejismo. Y uno nunca puede estar seguro de que no siga siéndolo.

El testimonio es precioso. Habría que resaltar varias cosas. Una metáfora vegetal para referirse al crecimiento de un poema, metáfora que quizá ya está en el uso común. A la metáfora de la semilla se une la mención del organismo que es el poema,

157 Algo parecido dijo a Babel, pero no con la misma prolijidad. 
un organismo que, cuando resulta un texto auténtico, respira. Quizá esta concepción del poema como organismo venga también de Silva. Ya dice Charry, en Poesía y poetas colombianos, "Vale más destacar, sin embargo, la consideración suya del poema como una totalidad, como un organismo independiente, como una naturaleza viva. Es algo que rebasa el aspecto puramente formal de la poesía" ${ }^{\text {158 }}$. Por otra parte, está la insistencia en partir de la experiencia y en la opacidad que llena el oficio. Un oficio que depende mucho del azar de los momentos felices, según Valéry, ya citado, debe encontrar compensación en el hecho que la bailarina lleve los ojos abiertos: la búsqueda es a ciegas, pero búsqueda activa. En otras palabras, es preciso que intervenga lo que llama crítica Valéry o pensamiento abstracto. Y también todo eso que está detrás del proceso creativo: visiones del mundo, como dice la "Nota". En fin, la necesidad de dejar reposar el texto para que tome distancia y así permita la crítica del poeta, es decir que este le pueda "echar tijerita", hacerle la "poda", como llamaba Arango la corrección del texto.

Ahora bien, lo determinante para la consideración que acá nos guía es la manera extraña como se va haciendo la reflexión: las palabras tienen la iniciativa, son las que buscan cómo asociarse, las que se van imponiendo. El poeta debe meditar sobre su experiencia y en esa meditación dejarlas a su encantamiento. Recordemos algo ya citado de David Jiménez: "Una obra poética como el "Nocturno" de Silva busca, quizá, antes que sorprender los asomos de una realidad invisible, pensada y tematizada en el poema, apoderarse de los efectos de encantamiento propios del ritmo verbal, más allá de la significación" (Pág. 21). Ahí está (Capítulo 3. Poesía y filosofía") la ponderación de la moneda de las transacciones diarias, su escucha, la mordedura...

158 “Tradición de Silva”, pág. 19. 
La verdad es que siempre me ha parecido extremadamente complejo y extraño el proceso. Me pregunto cómo puede salir un libro de poesía, con unidad temática, de un proceso en el que priman en tal grado la discontinuidad de los momentos. Pero es así. Y salen, como los de Arango, libros hermosos, con unidad clara.

\section{Verdad de la experiencia}

Arango ofrece una poesía muy cercana a la realidad y profundamente crítica de la misma. Una poesía que "no es útil, sino eficaz", hecha para transformar mediante la comprensión: la novedad radical actúa sobre la comprensión del lector, ofreciéndole una perspectiva nueva del mundo, como lo dice Vattimo, a propósito de una frase de Heidegger que vimos Arango asumió como propia ${ }^{159}$. Poesía muy próxima a la realidad de un lugar, dicha con unas palabras de un lugar, con un "dialecto", que sorprende por la manera como se pliega a los contornos de las cosas, para decirlas con toda su rudeza. En este punto, en la conexión con la realidad, es posible encontrar diferencias profundas con otros poetas colombianos. No hay en esta obra una gravitación en torno a la erudición: lo suyo son cosas cotidianas vistas, olidas, oídas, tocadas morosamente por alguien que se puso en la tarea de aprender a sentir. Por otra parte, claro que está en busca de la belleza, como me lo dice en la entrevista y como lo atestiguan sus poemas, pero ante todo está en busca de una verdad. Él

\footnotetext{
${ }^{159}$ Introducción a Heidegger, págs. 107, 108: “...aun la experiencia estética común encuentra siempre la obra de arte, no como un 'objeto' que se pueda colocar en el mundo junto a los otros objetos, sino antes bien como una perspectiva general del mundo que entra en diálogo con nuestra perspectiva y que nos obliga a modificarla o por lo menos a profundizarla. En todo esto, grosso modo, piensa Heidegger cuando habla de la obra de arte como fundación de un mundo".
} 
mismo lo dijo de William Carlos Williams ${ }^{160}$, con una de las palabras más importantes de la filosofía del siglo XX: "sentido":

Sí, él quería otra cosa. El destello del sentido ${ }^{161}$, más que el de la belleza, en las cosas mínimas, en un detalle, algo así como la iluminación de que habla el Zen..."

Para esta verdad de Arango, David Jiménez acuña la expresión "verdad de la experiencia”. Creo que no es difícil aceptar que Arango está en busca de una verdad, incluso cercana a la de Carrasquilla, opuesta a la de Miguel Antonio Caro -Ya en el capítulo sobre poesía y razón mostré la contraposición entre este Caro y Silva. Aquí habría que agregar que para Carrasquilla ${ }^{162}$, una novela es "un pedazo de vida, reflejado en un escrito por un corazón y una cabeza"-. Jiménez habla pues de verdad de la experiencia en el caso Arango ${ }^{163}$ :

Los poemas de Arango, breves pero no aforísticos ni sentenciosos, están desprovistos de toda pretensión de sabiduría general. Son sabios, pero a pesar de sí mismos, no por sus conclusiones. De ellos no pueden derivarse máximas de vida ni citas célebres. Poesía meditativa la suya, tremendamente crítica, seriamente ocupada en las tareas del descifrar y comprender. Como pocos poetas hoy en día, esta obra todavía se impulsa hacia una verdad, quizá reducida a la verdad de la experiencia. Pero la dice como lo aprendió de Emily Dickinson: "Tell all the Truth, but tell it slant" ("Di toda la verdad/ pero dila sesgada") (Subr. LHV).

¿No está, en esta manera de entender la verdad, una cercanía con Nietzsche? Ya Carrasquilla estaba cerca de aquel, pues que el conservador en materia política era confeso nietzscheano en cosas de arte. ¿No este otro punto de contacto: el otro era la muerte de Dios? Lo digo porque la opción es entre partir de la razón o partir de la experiencia. No se trata de echar por la borda la razón. Pero sí que parece haber una inversión del platonismo. "Mi filosofía, un platonismo al revés". Parece haber una

\footnotetext{
160 "La poesía de William Carlos Williams", pág. 54.

161 Interpreto aquí la noción de sentido desde Heidegger, desde la Aletheia. Dice la traducción de Rivera ya citada "Sentido es aquello en lo que se mueve la comprensibilidad de algo. Sentido es lo articulable en la apertura comprensora". El horizonte en que el nos enfrentamos a las cosas. Ver las citas de Gadamer y Vattimo hechas con anterioridad.

162 Citado por David Jiménez, "Miguel Antonio Caro: bellas letras y literatura moderna”, pág. 250.

163 “La poesía de José Manuel Arango", págs. 153, 154.
} 
toma de partida clara por el mundo sensible a costas del inteligible. Que puede ser así lo dice la insistencia de Arango en la experiencia, y el hecho de no partir de ideas, que es algo que busco aclarar un poco más en el siguiente apartado.

\section{Nada de abstracciones}

La poesía de William Carlos Williams ${ }^{164}$ está llena de naturaleza. De árboles, de flores, de animales. Sólo que no es una naturaleza "literaria". Son los gorriones que una vez, en El Paso, invadieron por miles un pequeño parque y sacaron a los que allí estaban, corriendo de huida de sus defecaciones. O las abejas que venían a beber en un día de calor a la pileta de los pájaros y se ahogaban en ella.

Pero, sobre todo, está llena de gente. De hombres y mujeres y niños. Gente del común. Este cojo de cara flaca y sombrero de hongo que se apresura para alcanzar la misa del domingo. O el niño del señor y la señora Kranz que, de lo gordos que tiene los carrillos, no puede abrir bien los ojos. Gente conocida y que ha sido observada en detalle.

Nada de abstracciones. No el proletario, categoría económica, ni el hombre urbano, entelequia de una poesía como la de Eliot, ni siquiera el "hombre medio", el buen salvaje del día. Ningún blando sentimentalismo, ninguna generalización sentimental. Tampoco la populosa relación de Whitman o de Perse. Quizá por eso sus figuras ganan en individualidad. (Subr. LHV)

Uno de los secretos de estos poemas, de su frescura, de la simpatía que respiran y que inmediatamente nos gana es la actitud del poeta frente a la gente. Que es también la actitud humana común. Estos seres de carne y hueso están tratados afectuosamente, no obstante su fealdad y sus deformidades. Williams atiende y hace ver, se burla y alaba. Esta es la vida, parece decir. Rica, fea, hermosa, inevitable.

Quizá es una exageración mía esta cita tan larga, tomada del ensayo que encabeza sus traducciones de Williams. Pero me parece que aquí nada es deleznable. Nada sobra. Como no sobra nada en este breve ensayo de Arango (Tampoco en sus ensayos sobre Rogelio y Arturo). Además es una confesión, un autorretrato. Ante todo, profundiza y ahonda su afirmación de que trata de no usar palabras abstractas ni conceptos en un poema. Y dice de manera positiva cómo hace su poesía para no incurrir en generalidades: observación en detalle de personas concretas, de cosas que están en el lugar: nada de tópicos. La indicación acerca de la actitud, me parece que es de las más valiosas: la manera de acercarse a las cosas con afecto y respeto.

164 “La poesía de William Carlos Williams”, págs. 51, 52. 
Ahora bien, sus observaciones acerca del punto de partida de los poemas en el individuo da mucho que pensar. Si se trata de buscar la verdad, choca contra Platón y Aristóteles: verdad en lo “individual”.

...bachué, señora del agua, enséñame a tocar..

Hay un poema ${ }^{165}$, "Baldío", del primer libro de Arango, en el que creo que está el poeta de la madurez (No me convence tanto el numeral 2, pero el primero es espléndido):

1

en la carnicería cuelga el tronco de la res desollada

como un fuego vegetal

por la cara sombría

de las vendedoras de flores

rebrilla el rojo de las rosas

entre el griterío cantan los pájaros

y la cáscara de plátano se tuesta bajo el sol de la tarde

bachué, señora del agua, enséñame a tocar

la fina pelusa bermeja del zapote

a ver la sal brillante en el oscuro lomo de la trucha

2

vestido con el pelo de las bestias

los pies cubiertos de un retazo

de piel de toro

165 José Manuel Arango, Poesía completa, Editorial Universidad de Antioquia, Medellín, 2003, págs. 40, 41. 
me detengo junto al baldío

donde el verde fértil de la maleza

afirma, en el corazón mismo de la ciudad

una pervivencia salvaje

La percepción es exacta. El trazo verbal, nítido. La frase es natural por los vocablos escogidos (Verdad que las vendedoras de flores no usarían la palabra desollada, la cual es culta; dirían más bien "descuerada”). La sintaxis es la propia del lenguaje ordinario. Aquí ya está lo que Arango dice que prefería William Carlos Williams: que sus figuras fueran individuales. La mirada sigue obediente a las cosas observadas y las entrega en su rudeza, esa rudeza que está en palabras como "rebrilla" y "tuesta", en los sonidos reiterados: "rebrilla el rojo de las rosas". Ya aquí, en este poema, está casi todo el Arango de la madurez. Las cosas han sido morosamente vistas, oídas, tocadas. Y esas cosas cotidianas son devueltas al lector por unas palabras ajustadas a ellas, de manera tal que hacen danzar llamas de rosas sobre la cara de las vendedoras, hacen oír en la algarabía de la plaza de mercado el canto de los pájaros. La enseñanza de Bachué - a quien pide le enseñe a ver y a tocarse generaliza después, logrando como resultado que, como señalé en "Cosas a un tiempo familiares y ajenas":

esas ciertas cosas familiares seguidas amorosamente nos las pone en los poemas de una manera tal que el muslo, la pierna entera, la suela, sienten la flor de gualanday pisada, jabonosa, que las yemas de nuestros dedos se ponen sobre el muslo de $\mathrm{La}$ diosa negra, que nos echa de para atrás la repulsa del salivazo que rueda como una moneda en el polvo.

“en la carnicería cuelga el tronco de la res desollada". Aquí ya hay un deleite en lo visto. La mirada ya es plenamente capaz de decir el entorno del poeta en toda su dura alegría, en todo su rudo júbilo. 
Este poema deja ver todo lo que significa partir de la experiencia. Está la convicción moral de que uno es de alguna parte, la toma de partido estético por una manera de hacer poesía que se ciñe a los contornos de las cosas, y sin duda hay posturas filosóficas como las que hemos venido entreviendo. $\mathrm{Y}$, finalmente, hay unas convicciones políticas: hay que pensar en lo que somos; si no es que esta convicción se entrecruza con convicciones estéticas y filosóficas. Estética: hay que compensar los efectos de la autonomía del arte, preocupándose por los demás. Lo dijo claramente en una entrevista Jaramillo Escobar. La poesía debe procurarse el respeto de los demás, preocupándose por sus problemas. Sí. El mismo X que en un poema pone: "Os han dicho, sí, yo sé, os lo han dicho, lo que es la poesía. La poesía es todo eso que os han dicho, y también esta cajita roja vacía en la que, como podéis verlo, no hay nada, absolutamente nada, sino ella misma sola por dentro”.

Pero si se nos muestran las convicciones de toda índole, se insinúa un cortejo de aprendizajes: necesidad de aprender a sentir, a observar las cosas: "para mí son muy importantes no sólo las montañas, sino los árboles con sus nombres, los lugares con los que estamos familiarizados, los usos y modos de ser y de hablar". "Austeros estudios", dice Baudelaire en el "Soneto a la belleza".

\section{De nuevo: ¿una tradición en la poesía colombiana?}

Es difícil encontrar temas cuya consideración sea tan importante para la crítica literaria como los que he intentado plantear. No sé si era a temas como estos a los que se refería la postulación, por parte Cruz Vélez, de la necesidad de una constitución de una filosofía sistemática del lenguaje poético, propuesta que habrá que examinar en su momento: aquí he llegado a estos problemas siguiendo la 
propuesta de Arango. Y, de acuerdo con este, temas como poesía y razón, poesía y filosofía, poesía y realidad son de urgente tratamiento.

En lo que al tema de este capítulo se refiere ( $Y$ teniendo como base los trabajos críticos de Charry y Jiménez), es notoria la manera como la consideración de la relación entre poesía y realidad atraviesa los textos. Un ejemplo. El texto "Sobre la presente antología"166, de David Jiménez, toma ya en su segunda página una noción de José Eusebio Caro, que es un hilo que atraviesa el tejido de su ensayo:

Si a un hombre como José Eusebio Caro, periodista, político involucrado en las más sectarias luchas partidistas de su tiempo y pensador arduamente dedicado a disquisiciones sobre el utilitarismo, aún le quedan tiempo y aliento para escribir poemas, ello se debe, seguramente, a su convicción romántica de que la poesía es una vía de acceso a una realidad superior. En uno de sus artículos periodísticos más ambiciosos en cuanto al alcance ideológico, titulado "La libertad y la virtud", afirmó que "las vías fantásticas y luminosas de la poesía", con sus aspiraciones a "abarcar el universo" y "contemplar el Infinito", sólo pueden explicarse por la "necesidad de expansión", un principio universal del espíritu humano que Caro aplica tanto a la esfera estética y moral como a la ciencia y al impulso viajero. Es la propensión a elevarse, a dar cumplimiento al sueño glorioso y absurdo de volar, a dominar con el pensamiento lo pasado, lo presente y lo futuro. Caro lo denomina también "instinto" y lo relaciona con la respiración, el amor, la pasión por la libertad, la necesidad de trascender los límites de tiempo y espacio, y muy particularmente con el sentimiento de sublimidad que experimenta el hombre frente al mar. (Subr. LHV)

La "necesidad de expansión” es uno de los conceptos que sirve a Jiménez para mostrar la noción de realidad en varios poetas colombianos. En la página 15 de mismo texto, se refiere a un poema del mismo Caro, "uno de los mejores poemas de amor de la poesía colombiana":

"Estar contigo" podría considerarse un poema "expansivo" hacia adentro; un intento de crear el espacio de intimidad amorosa con imágenes y palabras que la proyectan más allá de sí misma, hacia símbolos arquetípicos, anteriores a la sociedad y a la culpa.

166 "Sobre la presente antología", en: Antología de la poesía colombiana, pág. 10. 
Al concepto de "expansión” opone Jiménez el de "reducción”. La página 29 dice en lo que consiste la noción, al hacer tema de la obra de Luis Carlos López:

La experiencia poética no proviene, en esta obra, de la contemplación interior, de las vislumbres y promesas de una realidad superior. No es una poesía expansiva, a la manera de "En alta mar" [también de José Eusebio Caro, LHV], sino reductiva: comienza y termina en la experiencia sensible. De ahí deriva toda su riqueza y sus limitaciones.

Ahora bien: con estos dos conceptos, Jiménez hace algo más. Mostrar que hay un movimiento pendular en la poesía colombiana del siglo XX entre expansión y reducción (pág. 63), oscilación que mostraría la noción de realidad que se concreta en la obra de estos poetas:

En un movimiento pendular entre la expansión y la reducción, la poesía de Rogelio Echavarría, como la de Luis Vidales en Suenan timbres, sería un momento de reducción voluntaria, particularmente lúcida, mientras que la de Carlos Obregón, igual que la de Pombo o la de Aurelio Arturo, representaría un momento de expansión.

El texto de Jiménez cierra con José Manuel Arango (Pág. 65):

En la obra poética de José Manuel Arango se compendian casi todas las tensiones que caracterizan el desarrollo de la poesía colombiana. Es expansiva y simbólica, pero se contrae con el paso de los años y la madurez.

¿Movimiento pendular entre expansión y reducción? ¿'Tensión? No intentaré acá reflexionar sobre esto. Una lectura filosófica de la poesía colombiana debe examinar los alcances y límites de nociones como estas. Por supuesto que no se podría exigir a un texto breve como el de Jiménez Panesso -Va de la página 9 a la 68-, relato al hilo de su antología, que además abarca muchos otros temas: palabras de la poesía, modos de ser poeta, dificultades de la lectura de poesía, etc., no se podría exigir que discuta en detalle y justifique la utilización de estos conceptos. Pero una lectura rigurosa debe hacerlo: hay que hacer transparentes los conceptos. Por otra parte, es significativo, y de manera positiva, el hecho de tomar conceptos de un poeta notable. Y la reiteración de una palabra como experiencia en los fragmentos citados. 
Ahora bien, es conveniente intentar rozar al menos lo que quiere decir Jiménez con "tensión", y verlo en relación con un poeta como Arango. En las páginas 66, 67 se encuentra la siguiente consideración, la cual contiene, en la interpretación de Jiménez, otra palabra clave de la poesía colombiana del siglo XX, la noción de “epifanía”, y la entrelaza con la consideración de la noción de realidad, ya al final del siglo XX:

En sus primeros libros, Arango es un poeta epifánico, atento a las iluminaciones instantáneas. Estas pueden ocurrir en relación con lo más trivial, como mirarse las uñas, y en contraste, provocar una revelación de lo más arcano, como la muerte: "y te miras las uñas/ diminutos espejos de la muerte:/ en cada una un rostro/ de distinta edad y apariencia". O simplemente, en la mansa familiaridad de las calles, si la sombra de un árbol cuelga inmóvil sobre el muro blanco, "de pronto/ sin raíz", surge "el deseo/ de quedarse en este día, siempre". "Momentos", un poema del libro Cantiga, está dividido en tres segmentos, tres escenas mínimas de la vida natural, descritas con la minuciosa exactitud y la objetividad de un poeta "imaginista". Arango admiró con fervor a Williams Carlos Williams, el poeta norteamericano, y de él aprendió ciertas lecciones fundamentales: que el poema debe arraigar en lo inmediato, en lo cotidiano; que la música del poema debe mantenerse próxima al habla ordinaria y a sus ritmos; y, sobre todo, que la poesía de hoy debe omitir los "aspavientos metafísicos" y complacerse en lo sensible y concreto. En "Momentos", todo aparece ahí, en la superficie de la realidad inmediata, sin relación con otros planos de la realidad no sensible: los carboneros sobre el río, el ágil coletazo de la sabaleta, el vuelo del martín pescador y su tijeretazo sobre el agua. Imágenes sin más allá de lo visible y sin sujeto humano. Sin embargo, es posible entenderlas como epifanías, si aceptamos que el último verso, separado de las otras tres secciones, introduce en el escenario, al tiempo con el yo, una revelación: "soy un intruso en este reino/ de crueldad inocente". Es la naturaleza misma la que parece vivir más allá, en un espacio puro, inocente, ajeno a la historia y a la conciencia del hombre. Y así, mientras lo natural se aleja, alojado en su propio reino, el poema imaginista se aproxima a los "aspavientos metafísicos" del simbolismo, en el intento desmedido de penetrar lo insondable de esa otra realidad incontaminada.

\section{¿Antioqueñidad?}

Arango dice que la "reflexión sobre lo que somos" es de raíz antioqueña. Pero si esa reflexión consiste en una gran proximidad a lo real, la meditación sobre las lacras que tenemos, hay que decir que ella aparece en otros poetas y en otras latitudes distintas a la región antioqueña. ¿No será más bien que esa reflexión la recibió por la vía antioqueña pero no es, en Colombia, privativa de ella? Y ¿no pudo recibirla por otras vías, distintas a la colombiana? ¿O quiere esto decir que esta raíz antioqueña, 
siendo común a otros lugares, tiene unas especificidades? Y si es así, ¿cuáles son estas?

Arango no dice que solo es antioqueño. Habla además de que en su poesía también hay una raíz del altiplano cundiboyacense. Comúnmente se le asocia a una corriente de la poesía colombiana que parte de Silva: Silva-Arturo-Charry Lara-Giovanni Quessep, Jaime García Mafla, Arango. Es una corriente cuya definición por Charry Lara es muy repetida y que yo todavía no comprendo del todo: "tradición de lirismo, intimismo y expresividad". Hay que recordar que Juan Manuel Roca dice que Arango sí puede venir de esa corriente, pero de una manera espúrea.

Sea de ello lo que fuere, la reflexión sobre lo que somos puede venir de Silva. Es muy diciente que este sea para Arango quien entre nosotros planteó el problema de la poesía en esta época. Por otra parte, y para ceñirme estrechamente a nuestro tema, ya dijo Charry ${ }^{167}$ :

Varias de estas Gotas amargas debieron perderse para siempre, pero a través de las que han llegado hasta nosotros adivinamos el rechazo íntimo de Silva ante muchas concepciones del orden social y frente al comportamiento que, siguiéndolas, exhiben los hombres. [...] En este grupo de poemas, por los que desfilan algunas de nuestras más características flaquezas, el amor también enseña reiteradamente sus dobleces e hipocresías. Recuérdense, por ejemplo, los versos dirigidos a una doncella, en la que “jamás se habrá posado ni la sombra de un beso”.

Habría que decir que el señalamiento de las lacras y debilidades humanas no aparece solo en este grupo de poemas de Silva, sino también en la que podemos llamar "poesía seria" de Silva. Basta recordar el viudo de "Día de difuntos", que al año se vuelve a casar. Como dijo Arango, en Silva hay un "desgarramiento". Poesía "seria" y antipoesía se entrecruzan.

167 Divagación sobre Silva”, pág. 426 
Pero además Arango no forma parte solamente de una tradición antioqueña o colombiana. Desde Silva la poesía nuestra es cosmopolita: no solo tenemos la tradición clásica e hispánica sino también es nuestra toda la tradición. Occidental y oriental. Creo que en Machado, con cuya poesía, según confesión propia, creció, pudo encontrar también una crítica aguda a lacras sociales. Los poemas que, por lo menos a mi generación, mostró Serrat contienen una aguda crítica:

Este hombre no es de ayer ni es de mañana sino de nunca, de la cepa hispana no es el fruto maduro ni podrido.

Es una fruta vana.

Ahora bien, si "reflexión sobre lo que somos" significa, además de crítica a debilidades, un elaboradísimo apego a lugares y enseres, a modos de ser y de hablar, ¿eso lo encontró en Williams? Ya hemos visto lo que dice del médico. Era tan fuerte el apego de este a hablar de las cosas concretas que dice Arango que muchos de los poemas de aquel se "escribieron" durante sus caminatas de médico por las calles de Rutherford. Y era Williams decidido en su fijación a modos dialectales de hablar: él quería que en sus poemas apareciera no el idioma inglés sino el norteamericano. ¿Y Rilke? Jiménez explora su cercanía con Arango, comentando el poema "Costumbres de las palomas" ${ }^{\prime 168}$ :

Renunciar a las iluminaciones interiores del poeta romántico simbolista fue parte de un manifiesto del momento, nunca del todo cumplido en el propio Rilke. Pero la decisión de escribir poemas-cosas con una decisión casi artesanal, dejando a un lado las aspiraciones visionarias y ateniéndose a las exigencias del objeto y a sus contornos reales, puede resultar en últimas un ejercicio de fuertes implicaciones estéticas y de aprendizaje inapreciable. Las ganancias se tasan en términos como exactitud, sobriedad, aprender a ver, aprender a decir sin juzgar, afinar el lenguaje como un instrumento de precisión:

Desde el palomar - la caseta

168 “La poesía de José Manuel Arango”, págs. 122, 123. 
desteñida, clavada

en la horqueta del tronco

del pisquín- la paloma

se deja caer a la era

de grava.

(Pájaro de ciudad la paloma,

su huevo azul

tiene un pichón de sangre

diminuto en la yema).

Creo que la pregunta por la reflexión sobre lo que somos, en la cual se concreta una manera de entender la relación entre poesía y realidad, es preciso formularla con más detenimiento. Sería imprescindible un estudio atento de Fernando González y de Carrasquilla, de Epifanio Mejía. Y mirarlo en conexión con algunos momentos de de Greiff. Con Echavarría y Jaramillo Escobar. Esto si contamos solo con la tradición antioqueña. Porque queda la pregunta por la relación de Arango con poetas colombianos como El tuerto, José Eustasio Rivera y Eduardo Carranza. Aunque creo que el trabajo de observación de las cosas y de los modos de hablar llega en Arango a niveles extraordinarios.

Me inclino por ahora a pensar que lo que Arango dijo es que había bebido esa "reflexión sobre lo que somos" en la tradición antioqueña. No se puede leer ahí nada más. Finalmente, y para robar una expresión de un amigo mío: "Patria es el lugar desde nos incorporamos al mundo".

Arango escribe en castellano, un castellano en el que es fuerte el acento dialectal, como era fuerte su peso en su manera de hablar. Poesía en castellano que se ha formado con tradiciones diversas. La filiación de Arango la contrae David Jiménez, en su ensayo sobre su poesía, en la fórmula "el romántico simbolista de hoy". 
Romanticismo alemán, tradiciones hispánicas, simbolismo, surrealismo, expresionismo, imaginismo, budismo entran en su poesía. Quizá reinterpretadas como en el caso del surrealismo ${ }^{169}$, pero en un juego que él llamó de manera muy sugestiva, refiriéndose al imaginismo, como "transfusiones", "inoculaciones": el imaginismo toma cosas de la poesía de lengua española, y Arango toma cosas del imaginismo. Claro: dijo que la patria es la lengua, pero desde ella y para ella acude a dos o tres idiomas más.

Con el tema de la reflexión sobre lo que somos ocurre quizá como con la concepción general de la poesía. Arango escribe un poema como "La bailarina sonámbula", y sin haber leído al Valéry teórico sucede que tienen una concepción muy parecida de la poesía. Estamos mucho más cercanos en esta que ahora es aldea universal de lo que podemos imaginar.

\footnotetext{
169 "Es sabida la posición de Lezama frente al surrealismo, hecha de atracción y desconfianza, de aceptación y negación. Él no concebía el poema como fruto de un abandonarse al sueño, como una ganancia en aguas revueltas. Quería la vigilancia, la búsqueda activa. La bailarina sonámbula lleva los ojos abiertos”. Y en la entrevista de Babel (págs. 11, 12):

“Babel: ¿Piensa usted entonces, que la poesía es un acto del inconsciente, que hay temas que se escriben y que luego al leerlos, se ve que se va más allá, que no se pretendió decir eso?

"Arango: Estoy completamente de acuerdo. En un poema hay una parte oscura que me parece a mí que es la que da el peso poético. Sí, es como en los sueños. ¿Por qué se sueña con esto y no con aquello? ¿Por qué, cuando se recuerda el sueño -si es que lo recuerda-, se sorprende de ciertas cosas inesperadas? Ciertas imágenes, para utilizar un término común al sueño y al poema.

“Babel: Recuerdo algo de Dalí...

“Arango: Bueno, no se trata de surrealismo, o al menos no se trata del método de escritura de los surrealistas, de la escritura automática. El pintor surrealista está limitado por unas cuantas imágenes, se tiene que ceñir a ellas, pero la escritura automática lleva muchas veces a la incoherencia”.

Arango, Valéry, Lezama. Y Álvaro Mutis y Charry Lara, según Jiménez, tienen la misma posición, es decir aceptación parcial del surrealismo, la libertad imaginativa y de la prosodia. Pero: "Ambos encuentran en la escritura automática una restricción inaceptable, especie de dogma impuesto a los prosélitos como parte esencial de la ortodoxia surrealista. La finalidad de la actividad poética, para ellos, no es producir un documento sobre la vida onírica, sino un poema, un objeto que tiene un fin en sí mismo y cuyo valor no es testimonial sino estético. 'La voz sonámbula, si delira, es por las calles de un invariable mediodía mental"' (Antologia de la poesía colombiana, pág. 50).
} 


\section{Capítulo 5. Problemas de la lírica}

El 8 de junio de 2009 asistí a una conferencia sobre la poesía colombiana del siglo XX. Dictada por Juan Gustavo Cobo Borda, en el Centro Cultural "Reyes Católicos”, de Bogotá, me permitió reflexionar sobre algunos problemas de las obras del siglo XX (Cobo Borda insistió particularmente en el carácter "trunco" de obras fundamentales del siglo). Por otra parte, alimentó mi juego, consistente en buscar las palabras claves de esta poesía. El 12 de junio siguiente le hice una entrevista al crítico, que permitió retomar algunos de sus temas. Al oírla de nuevo, me doy cuenta de que es, en buena parte, una nueva conversación sobre Arango, que aún no he tenido tiempo de editar ( $\mathrm{Y}$ de completar, porque acordamos hacer una nueva sesión para "redondear").

Vuelvo ahora sobre los temas indicados, alrededor de dos preguntas: ¿Qué carácter muestra la poesía colombiana del siglo XX, vista desde la perspectiva de sus palabras fundamentales? ¿Qué problemas ha tenido que enfrentar esta poesía? Hay que decir que el título "problemas de la lírica", tomado de Benn a través de Arango, como se verá más adelante, se puede desglosar en los problemas de la poesía, del poeta, de la obra y del lector de poesía (Reconozco en esto la deuda al "Origen de la obra de arte", de Heidegger, texto que se mueve cada vez más hondo en el círculo que trazan estas palabras). Así mismo, para el caso del poeta se puede preguntar acerca de las formas como se han asumido ellos en este siglo. No se trata, como lo hemos hecho hasta ahora, más que de un intento de precisar problemas, al cual deberá volver la lectura filosófica propiamente dicha. 


\section{Duro cráneo/vasija de sueño...}

Un poema de Signos pide al cráneo, vasija de sueño, que descifre "la escritura del viento, sus trazos/en el agua nocturna". Difícil encontrar una palabra que pueda, como el vocablo sueño, encerrar al menos una de las grandes vertientes de la poesía colombiana en el siglo XX. Digo esto porque creo que si hay algo aceptado por los críticos es que en el siglo XX colombiano salen dos vertientes de Silva. Arango mismo habla de poesía y antipoesía:

El desgarramiento, el conflicto de Silva han sido muy fecundos. Dice que el verso es vaso santo y que sólo se puede poner en él un pensamiento puro, y sin embargo escribe las Gotas amargas, que son mucho más agresivas que la antipoesía que vino después, incluida la de Luis Carlos López.

Yo creo que la oscilación que se ve en la poesía de hoy - ¿o ya es de ayer?- entre antipoesía y búsqueda de caminos más oblicuos o secretos para celebrar, eso ya estaba en Silva.

Integrarían la primera de estas dos corrientes (Antipoesía): Silva-Eduardo Castillo-Luis Carlos López-León de Greiff ${ }^{170}$. Poesía: Silva-Aurelio Arturo-Charry Lara-Arango (Charry colocaba en esta corriente a Castillo, Quessep y Mafla). Y ya vimos lo que dice Roca de la pertenencia de Arango a esta corriente: Sí, pero "espuria". Quiero decir que cualquier clasificación de este tipo es problemática, pero ayuda. (Ahora bien, para apenas indicar una pregunta de paso, ¿no será que estas dos corrientes comparten la creencia en el cielo vacío? ¿Ciertamente con la excepción de

\footnotetext{
170 “Silva, Castillo, Luis Carlos López, León de Greiff tienen en común esa especie de exasperación con la poesía. Todos, en algún momento de su obra, se lanzaron contra la belleza, contra las convenciones poéticas, y crearon una máquina de rechazos, burlas y, en últimas, de impulso deliberado de suicidio. La severidad con que trataron la poesía los condujo a empequeñecerla, hasta reducirla a antipoesía, como sucede en Gotas amargas, molde inicial al que se ajusta buena parte de esta tendencia. León de Greiff convirtió en tema frecuente este ejercicio de desconfianza en la poesía, pero lo hizo en el más elaborado lenguaje poético, deudor de refinadas tradiciones, antiguas y modernas. 'La poesía parecía ser cosa sería. Poesía/ no es sino Nadería'. De Greiff repite el estribillo, se embelesa con él. El poeta es 'Rey de Burlas', lleva 'cetro de cañas', 'tirso y cascabeles de bufón'. No obstante, para él, igual que para Silva y Castillo, la poesía es un absoluto" ("Sobre la presente antología", en: Antología de la poesía colombiana, pág. 34). Es claro que la palabra que parece precisa para lo que ocurre en Silva es "desgarramiento".
} 
Guillermo Valencia, el único creyente entre los grandes poetas del modernismo y de la poesía colombiana del siglo XX?)

De acuerdo con lo dicho, la pregunta inicial de este capítulo debe ser entendida, con base en esta precisión de la noción de poesía, como referida a una de las corrientes que abre Silva, poesía que a veces llaman "seria", quizá por las bromas que la otra comporta. Así pues: ¿Qué carácter muestra la poesía colombiana del siglo XX, vista desde la perspectiva de sus palabras fundamentales?

¿Cuáles son esas palabras? En la conferencia del 8 de junio, Cobo Borda consideró palabras como ausencia, música, silencio, sombra, simpatía (hacia las cosas), sueño (que no se concreta), evasión. La lista de palabras de Cobo, vale la pena confrontarla con la que hice en el texto de mis reflexiones sobre la poesía de Arango. Hay muchas coincidencias. El escrutinio hecho al considerar sus poéticas, me dejó la siguiente afirmación: "Sueño, muerte, ciego, silencio, música, caos, noche, familiar y extraño, palabras asociadas a la poesía en Este lugar de la noche”. Estas palabras del primer libro se mantienen en la obra de Arango, aunque en algún momento entra alguna nota irónica, ligada en su caso, a presencias femeninas, nota que se puede ver ya en el "Tercer Nocturno", de Silva o en la "Perorata", de Jaime Jaramillo Escobar. “Caracola” (Pág. 231):

\footnotetext{
He oído

en el entresueño algo como un rumor de mar que amaina y arrecia.

Me han llegado
} 
en el entresueño

voces como de mujeres en el amor

o como de sirenas.

Pero sé que el oído

es una delicada caracola

metida dentro de mi cráneo

y que en ella hay un arpa diminuta

de vivas pestañas.

Qué agua, qué risa.

Sé que es sólo, desde mi torre,

ese rumor oscuro de la ciudad

que es como el ronroneo de una fiera dormida.

Lo nuevo es la veta irónica: "Qué agua, qué risa”. (¡Qué va!, dice el lenguaje popular). No el tema de sueño, que ya estaba en Este lugar de la noche. Habla de entresueño, palabra que también aparece en ese primer libro: "Duermevela", se titula un poema. Esa veta irónica como ya dije se encuentra en Silva: “Cómo tendéis las alas, ensueños vanos" o en Jaramillo Escobar: “Os han dicho, sí, yo sé, os lo han dicho, lo que es la poesía. La poesía es todo eso que os han dicho, y también esta cajita roja vacía en la que, como podéis verlo, no hay nada, absolutamente nada, sino ella misma sola por dentro”. El adjetivo en Silva y en Jaramillo Escobar es el mismo: vano, vacío. Se trata de "naderías", como dice Borges. Esta veta irónica creo que la comparte Arango también con William Carlos Williams. Hay que mirar una de las traducciones de Arango: "Retrato de una dama"

Dije que esta manera de concebir la poesía se mantiene en Arango. Agrega, luego, otras palabras fundamentales como baile. Creo que casi todas esas palabras se resumen en el poema "La bailarina sonámbula": mujer que sueña. Con la excepción de muerte y ciego, aparecen ahí explícitas. Pero es tanta la insistencia de Arango con la relación muerte y poesía, que sabemos que de uno u otro modo debería estar ahí.

171 Whitman, Dickinson, Williams. Tres poetas norteamericanos, Norma, Bogotá, 1991, pág. 116. 
En cuanto a "ciego" 172 y sordo y en general casos límite del lenguaje, igualmente hemos podido apreciar la importancia que tienen en la reflexión de José Manuel. Por otra parte los ojos de la bailarina están abiertos pero por supuesto que no ve nada:

La poesía debe ser un baile. El ritmo, la música le son consustanciales. Si la prosa corresponde al caminar llano, la poesía corresponde a la danza. Debe pues empinarse, alzarse un tanto del suelo, levantarse sobre la prosa de la vida ordinaria como la bailarina se pone en puntas de pies.

Por otra parte están la hora, la oscuridad necesaria, el sueño. Es de noche, naturalmente. Solo en la noche puede darse el baile de una sonámbula. Tal vez sale a bailar por las calles, aunque no se sabe de nadie que la haya visto. El baile comienza en el sueño y en cierto modo se mantiene dentro de él. Pero es también más que el sueño y se arranca de él. Es sabida la posición de Lezama frente al surrealismo, hecha de atracción y desconfianza, de aceptación y negación. Él no concebía el poema como fruto de un abandonarse al sueño, como una ganancia en aguas revueltas. Quería la vigilancia, la búsqueda activa. La bailarina sonámbula lleva los ojos abiertos (Subr. LHV).

Lo curioso de estas palabras es que, según Jiménez, casi todas se encuentran en

Charry Lara ${ }^{173}$. A primera vista, tal cual (¿Quizá la bailarina sonámbula resume la poesía "seria" o lunar, como también le dicen, del siglo XX?):

"He venido a cantar sobre la tierra las cosas/ que se olvidan o se sueñan", escribió Fernando Charry Lara en uno de sus poemas. Según él, lo fundamental para la poesía ocurre en el sueño. Éste es el auténtico reino de lo poético. "El verso llega de la noche", de ella nace el rumor que se convierte en poema por obra del que sueña. La duermevela, el inconsciente, lo olvidado y a medias recordado ésa es la materia de la poesía [...] Las palabras repetidas del poema son las claves verbales de toda la poesía de Charry: noche, sombra, soledad, sueño, lluvia, muerte, olvido.

Ya hemos visto cómo Charry se distancia en puntos del surrealismo. Ahora bien, no creo que, pese a la coincidencia de Arango con Charry, la "bailarina sonámbula" esté desde el comienzo en esta vertiente de la poesía colombiana. Creo más en la conjetura de que se llega a este poema "resumen" al cabo de un largo recorrido, y que

\footnotetext{
${ }^{172}$ Cobo Borda convino en la necesidad de considerar esta palabra. Me dijo que la poesía de Roca es de ciegos. Recordó así mismo en Mutis algún poema sobre los ciegos. Le recordé que en "Cada poema", de aquel, hay unos versos: "Cada poema nace de un ciego centinela/ que grita al hondo hueco de la noche/el santo y seña de su desventura". Barba Jacob, por su parte, dice: "Mi mal es ir a tientas con alma enardecida,/ ciego sin lazarillo bajo el azul de enero". Ya señalé cómo en el caso de Arango la indagación sobre la ceguera es muy particular por hondura y riqueza: indagación de profesor y de poeta.

173 "Sobre la presente antología", págs. 48, 49.
} 
en esa concepción hay puntos de separación, como es natural, entre Arango y Charry. Este mismo, en el último párrafo de la "Divagación sobre Silva" señala algo que sugiere un proceso:

Clarividente y rebelde, José Asunción Silva intuyó el sonambulismo de poesía muy posterior a la suya, su reiterada lucha de claridad y de delirio, su atmósfera de oleaje oscuro. Lucidez, embeleso, enajenamiento. Por eso su obra no nos es indiferente.

Creo que estas son las palabras de una vertiente de la poesía colombiana: la que aquí hemos llamado poesía. Como quien dice, poesía por antonomasia. Cosas de la inadvertencia: aunque repetí mucho que en Arango es muy importante el instante, no lo resalte en mi libro. Destaqué que en su obra aparece el súbito del encuentro entre lo familiar y lo ajeno propio de la experiencia base del poema. Ahora que, con el recorrido hecho, se aclara qué es lo que el poema tiene de instante: es instante por la experiencia que le sirve de base ${ }^{174}$. No es porque el poema en sí mismo consigne un solo instante: incluso puede ser suma de instantes. Esta palabra se reitera en Jiménez: "visión romántica de los instantes privilegiados"; “instantes de iluminación”, “momento epifánico” ”, en algunos poemas de Maya. Como se puede suponer, la palabra aparece en muchos otros lugares de su texto, de los cuales creo que vale la pena destacar $\operatorname{dos}^{175}$ :

Casi todos los poemas del libro Los emisarios [De Mutis] se refieren a estos instantes de iluminación, "mezcla de asombro y de gozo"

\footnotetext{
${ }^{174}$ En su conferencia sobre "El eterno retorno de lo mismo" está el siguiente comentario sobre Nietzsche, que me da vueltas a la cabeza pensando en la poesía de Arango y en la vertiente en la que se inscribe su obra: "Sobre el hecho de que no se trata de una eternidad inmóvil e inmutable, testimonian estos otros fragmentos: 'Contra el valor de lo que permanece eternamente igual a sí mismo (v. La ingenuidad de Spinoza e igualmente de Descartes), el valor de lo más breve y pasajero, el seductor brillo dorado en el vientre de la serpiente -vita" (9 [26]: KGW, Vol. VIII, Sección 2, pág. 12)". En: Ramón Pérez Mantilla. Textos, editores Lisímaco Parra y Luis Hernando Vargas, Universidad Nacional de Colombia, Bogotá, en prensa.

175 Ibídem, págs. 53, 56, 57, 66.
} 
Si mañana despierto, el último y definitivo libro de poemas de Gaitán Durán, es una celebración del mediodía, del sol y de la luz, metáforas del instante de plenitud y de su fugacidad [...] El yo que habla en el poema de Gaitán escoge creer en este mundo, en soles y rosas rojas. Aquí, donde todo es fugaz como el día que muere, el amor es también dádiva transitoria: por ser un don de esta tierra, se pierde con ella. Pero quedan la imaginación y la poesía para inventar la eternidad del instante y "como un dios, crearme en tus pupilas".

Una de las palabras que aparece en Charry, y que no aparece en mi lista de palabras de Arango, es la palabra lluvia. No me detendré ahora en esto, pero valdría la pena comparar los poemas de Aurelio y de Arango sobre la lluvia. En este último, hay versos que dejan ver que ella reúne muchas de las palabras de la poesía del siglo XX: "El olor de la tierra cuando viene la lluvia/ese olor íntimo de hembra./ (El toro echado alza,/ ávido la cabeza.)" (Pág. 219). En el poema la lluvia "trae" la mujer, y aparece ahí un niño ciego; la lluvia copia los sueños y hay un ruego a la "aguamadre, aguamuerte". Habría que mirar también el "silabeo" de la lluvia en Arturo... Quizá estos poemas tienen todavía mucho que decirnos, mucho que no hemos visto ${ }^{176}$.

La indagación de Arango sobre la poesía nos ayuda a ver mejor la corriente de la poesía colombiana en la cual se inscribe su poesía. La concepción que esta tiene se manifiesta de manera sobresaliente en su bailarina. Como todas las metáforas, esta no alcanza a recoger todo el fruto de una meditación intensa, pese a que ha tomado su tiempo para hacerse, en el curso de una historia y como fruto de una tradición. El poeta arraigado en su tierra y en su tradición no desdeña aportes universales pero está ahí haciendo crecer lo que se le ha dado.

\footnotetext{
176 Machado dice de una manera tremenda lo que pasa cuando se unen agua y tierra: "Algo que es tierra en nuestra carne siente/ la humedad del jardín como un halago". ¡Y qué decir de "Paraíso regado", de Jorge Guillén!
} 


\section{Los problemas de la poesía colombiana del siglo XX}

Si hablamos ahora de las dos vertientes abiertas por Silva, y no nos limitamos a una sola de ella, aparecen al menos cuatro problemas. De ellos Arango muestra dos con nitidez: la posibilidad de la poesía y la falta de claridad acerca de su función. También tiene algo que decir sobre el carácter "trunco" de las obras y lo que podemos llamar la penuria del lenguaje poético.

\section{...la pregunta por la posibilidad de la poesía}

“Todavía vivimos, me parece, en la problemática que él planteó. La pregunta por la técnica y el progreso, la pregunta por la posibilidad de la poesía". Posibilidad de la poesía. Esta frase tiene un doble sentido. Uno puede entender que Silva se planteó cuáles eran las posibilidades de la poesía en la época de la técnica y el progreso: esto está asociado a la pregunta de Baudelaire por la belleza en estas ciudades modernas, una nueva belleza surgida con ellas. Pero también puede entender que Silva era un poco escéptico con la poesía en esta época. Que temía que no tuviera posibilidad.

Las dos opciones son válidas, si se tiene en cuenta el "desgarramiento de Silva". Por una parte, esbozó el programa de una manera de hacer poesía que según sus palabras busca las formas precisas de la realidad y las formas imprecisas del sueño. La buscó en palabras sencillas que se unen mediante el sortilegio de la música, al amparo de una indagación de sensaciones. Pero por otra parte está su antipoesía, que deja ver su descreimiento ("La tierra, como siempre, displicente y callada,/ al gran poeta lírico no le contestó nada":

Una parte significativa de la obra poética de Silva, sus Gotas amargas, está explícitamente dedicada a destruir no sólo la idea de la poesía inspirada sino también la pretensión de iluminar al lector con un destello simbólico. La ironía del poeta se vuelve contra sí mismo, contra la tradición romántica, contra las creencias en que se sostenían sus poemas anteriores. Si "Resurrecciones", por ejemplo, habla de las "ocultas fuerzas/ silencios, luces, música y sombras" que guarda el interior del 
hombre y que se responden, como eslabones de la misma cadena, con formas análogas de la naturaleza, en el polo opuesto, "La respuesta de la tierra" es una broma sarcástica que pone en ridículo las aspiraciones del vate sacerdotal a desvelar los misterios de la vida y de la muerte. El crítico Sanín Cano asegura que a los modernistas, y Silva se mostró agudamente consciente de eso, les tocó hacer su obra en un mundo cansado de la poesía y de los poetas. Algunos creyeron que era inminente la muerte del arte y de la literatura. Eso ayuda a entender por qué, con tanta frecuencia, se sintieron visionarios, voces proféticas de un futuro sin alma... ${ }^{177}$

\section{¿Obras truncas?}

En la entrevista, me dijo Cobo, que hay como una vertiente colombiana de obras truncas. Para ejemplificar me habló de Aurelio Arturo, comparándolo con Juan Rulfo. Dos "hermanos" que, me decía, hicieron una obra espléndida y luego quedaron sin nada que decir. Y que tuvieron que aceptar la dignidad del silencio. En esto Cobo Borda quizá está inspirado en Danilo Cruz Vélez, cuando habla del segundo ciclo de Arturo:

El poeta publicó estos tres poemas probablemente como una muestra de algo nuevo que apenas comenzaba a alborear. Si ello es así, y si no se encuentra una continuación del nuevo ciclo en su legado póstumo, se puede decir que con la muerte de Aurelio Arturo en 1974 se hundió por segunda vez en la sombra la promesa de un poeta colombiano de significación universal. La primera vez fue en 1896, cuando muere José Asunción Silva a los treinta y un años de edad.

Claro que murió Silva antes de ajustar los 31 años, y uno podría especular acerca de lo que hubiera podido hacer de haber vivido más. De pronto hasta le habría ido al fin- mejor en los negocios e incluso abandonado la poesía. Pero estas son especulaciones sin fundamento. Es posible que sea cierto que entre los modernistas es quizá más importante la obra de Darío que la del bogotano. Pero afirmaciones como esta me dejan mal sabor de boca, aunque todavía no entiendo del todo. ¿Qué quiere decir esto de la significación universal? ¿Realmente fue Arturo solo un pequeño gran poeta, como dice Cruz Vélez? Cuando esto se une a la postulación de la tradición de la pobreza, podemos negarle importancia a poetas que

177 Ibídem, pág. 23. 
verdaderamente la tienen. ¿Le pasó esto a Cobo Borda en su estupenda Antología de la poesía hispanoamericana, en la cual inexplicablemente excluye a Aurelio Arturo?

Creo sin embargo que hay algo de verdad en lo dicho por Cobo, pero hay que matizar, porque puede ser un problema de la lírica en este tiempo. Arango no solo habló de Benn, comparándolo con el otro médico, con Williams; lo hizo al comienzo de su ensayo sobre Rogelio Echavarría, autor "de una obra medida y sopesada, rumiada y sufrida". Creo que es significativo lo que cita -Lo que destaca-:

Gottfried Benn, que sabía de las exigencias que comporta escribir hoy poesía, hace hablar a la Moira, a la Parca, en su conferencia "Problemas de la lírica": “...quiero decírtelo al oído: una totalidad voluminosa es un sueño arcaico, sin ninguna conexión con la hora actual. Y hasta llega a hacer esta afirmación extrema: "Ninguno de los grandes líricos de nuestro tiempo ha dejado más de seis u ocho poemas perfectos: los restantes pueden resultar interesantes desde el punto de vista biográfico y evolutivo del autor, pero pocos son los que pesan por sí o fascinan durante largas épocas. Y para esos seis poemas, pues, de treinta a cincuenta años de ascetismo, sufrimiento y lucha. Es que escribir un poema no es asunto fácil: "tras un poema se perfilan los problemas del tiempo, del arte, de las bases internas de nuestra existencia, de forma más nítida y radical que tras una novela o incluso una obra dramática".

Confieso que este es un problema que aún no logro articular. Pero me parece que planteó mal el problema Cruz Vélez: las obras de Silva y de Arturo valen aquí y en cualquier parte. Me quedo, finalmente, con lo que parece una respuesta de Arango a la presunta tradición de la pobreza (Repito lo que dijo en la entrevista de Babel, pág. 17):

Una cultura es un tejido delicado, y no se hace de un momento a otro ni partiendo de cero. Para qué voy a romper con Fernando González si él me dice algo, si leo y veo muchas cosas que él me muestra. O con Carrasquilla [Tomás], Epifanio [Mejía]. Son nuestra tradición viva. Si es pobre, porque no son muchos los maestros que tenemos, con mayor razón hay que cuidarla.

\section{Empobrecimiento de la experiencia y de la dicción poética}

Este asunto también permite plantearse más nítidamente a partir de las reflexiones de Arango sobre Echavarría. A partir de una alabanza entusiasta: "El 
poeta ya no se da ínfulas. Es uno más, otro de esos todos. Lo que dice sabe a palabra de todos los días". Alabanza: lo dice un hombre que concibe su poesía como el trazo difícil hecho sobre la moneda de la comunicación cotidiana.

Pero tras la alabanza está una de las limitaciones de la poesía moderna: ya no hay un lenguaje poético aceptado por todos. Esto es un ruido en la comunicación entre el poeta y su lector. Hay que aceptar que no todos los poetas están en el mismo lío. Pero hay muchos que sí lo están. Y no solo de nuestra inmediata tradición. El gigantesco poeta de Cántico, Jorge Guillén, creo decía que no hay palabras poéticas sino palabras en el poema. En una de sus décimas memorables (Porque se alojó en mi memoria), unos sonidos bruscos, ásperos casan sin incomodidad: “Todo es cúpula. Reposa/ central sin querer la rosa/, a un sol en cenit sujeta”. El gran poeta que es Echavarría es un valioso ejemplo del problema. ¿Cómo lo plantea Jiménez? ${ }^{178}$ :

El lenguaje, al acercarse al habla común, renuncia a cualquier pretensión de ser palabra iluminada, cosmogónica. Lo más importante en la obra de Rogelio Echavarría es la novedad del tono. En esto se distingue de los poetas anteriores: Charry Lara, Aurelio Arturo, Gaitán Durán suenan a épocas anteriores. Echavarría no parece un contemporáneo suyo sino de los poetas que le siguen. [...] Ningún poeta colombiano había asumido, como lo hace Echavarría, los costos de la modernidad en términos del empobrecimiento que implica para la experiencia y la dicción poética. Encontrar un lenguaje que, sin renunciar a la expresión personal, logre al mismo tiempo una aproximación a los lectores de hoy y al mundo de la prosa urbana en que viven, significa ceder algo de la riqueza atesorada en la tradición poética [...] sin embargo, virtudes esenciales como la precisión, la intensidad, la condensación, la fuerza metafórica, se mantienen y son notorias en los mejores versos de El transeínte.

Hay que decir sin embargo que también poetas como Mutis se mantuvieron atentos a la búsqueda de la palabra en el poema. Recordemos la cita de Charry colocada al comienzo de esta obra.

${ }_{178}$ Ibídem, págs. 64, 65. 


\section{Hubo tiempos en que su lugar parecía claro}

Detrás de estas palabras late la preocupación por la función social de la poesía. El poeta no expresa creencias colectivas. Hace falta un piso social compartido. Escribe para aclararse a él mismo. Desde Pombo se distingue del periodista que tiene que escribir para los demás. Como se puede ver, este tema de la poesía se entrelaza fuertemente con el problema de la lectura de poesía. Pero hay algo que es preciso señalar acá-Y dejemos que lo haga Arango ${ }^{179}$ :

Yo creo que la poesía sigue estando presente. Desde luego, su manera de estar ha cambiado. Ya no es la relación del bardo con sus oyentes, ni siquiera la más profana del juglar. Antes de los mass-media - y la imprenta es, hasta cierto punto, otro medio masivo más-, se daba un contacto más inmediato entre el poeta y su audiencia. Pero esas diversas relaciones suponían, todas, un mundo compartido de creencias, en lo fundamental religiosas. Curiosamente, la invención de la imprenta coincide con el comienzo del desmoronamiento de ese mundo. Hoy sólo nos quedan fragmentos de esas visiones. De ahí la soledad en que se encuentran tanto el que escribe como el que lee poesía. Sin certezas, con sólo perplejidades y preguntas.

Lugar de la poesía: un tema que entrelaza asuntos como la modernización, la secularización y la autonomía del arte. Cada una de las palabras merecería encabezar una reflexión sobre la poesía colombiana del siglo XX. ¿Quizá una consideración más puntual de obras como las de Gutiérrez Girardot (sobre todo) y del mismo Jiménez?

\section{...el público es casi siempre una mesa y no un piano}

Estas palabras de Silva en la novela De sobremesa se encuentran al final del texto de David Jiménez "Miguel Antonio Caro: bellas letras y literatura moderna". El contexto es el que sigue: “Golpea con los dedos esa mesa, es claro que sólo sonarán unos golpes; pásalos por las teclas de marfil y producirán una sinfonía: y el público es casi siempre una mesa y no un piano que vibre como éste”.

\footnotetext{
179 "La poesía es eficaz, nos cambia”, pág. 10.
} 
A lo largo de este texto he insistido en dificultades específicas que comporta la lectura de Arango: es difícil saber si hay que hacer una lectura simbólica. Y esto sucede en muchos casos. La dificultad no es privativa de Arango. Con frecuencia uno no sabe qué hacer con el Vallejo de Trilce e incluso de poemas humanos: ¿cómo leer por ejemplo un poema como ese que comienza: "La paz, la abispa (Sic!), el taco, las vertientes,/el muerto, los decílitros, el búho", un poema donde no hay una sola oración completa. Se dirá que es cosa de los vanguardistas: sí; pero nuestro romántico-simbolista tiene sus dificultades con el lector de la contemporaneidad.

En dos poemas que ya consideramos en el capítulo "Filosofía y poesía", con base en una reflexión sobre el lenguaje de la poesía, Arango hace tema de dificultades que encuentra el lector y de exigencias hechas a este. Hay dos aspectos que deben resaltarse: el primero es que Arango parte de la consideración del lenguaje; el segundo, que parecen indisociables poeta y lector. Las dificultades son consideradas en el poema "Escritura" que comienza diciendo: "Marcar una moneda con la uña..." No solo es demasiado azaroso: es casi imposible que se dé el encuentro entre poeta y lector. No sé si usted, por ejemplo, ha intentado el juego propuesto: apenas acepta la moneda el trazo; apenas es perceptible.

Las dos últimas páginas del ensayo de Jiménez (págs. 258 y 259) ya citado se detienen cuidadosamente en estas dificultades, con lo cual ayudan a aclarar el examen de Arango:

El programa de interiorización de todos los valores en la poesía lírica se cumple, para la literatura hispanoamericanas en el modernismo. En Colombia culmina con Silva, pero ya se había iniciado en algunos poemas juveniles de Pombo. La poesía moderna, la que Silva leía y a través de la cual llegó a desear ser poeta, la de Baudelaire o Swinburne, por ejemplo, ya no es más la expresión de ideas generales o de creencias socialmente compartidas, mediante la utilización de un acervo convencional de formas que cumplen una función de comunicación con el lector. El lugar de la universalidad de la idea lo ocupa ahora la instantaneidad de la sensación. 
La función comunicativa de la forma, entendida ésta como convención anterior al poema, perteneciente a un almacén de procedimientos disponibles, se cambia por la búsqueda de una palabra libre, huidiza y sugeridora, cuyo poder no consiste en ser equivalente de un concepto o de una creencia, sino en abrir, mediante sus posibilidades musicales, un espacio a la insinuación de lo desconocido. La lectura de poesía se convierte así en un arte difícil, un arte para pocos, pensaba Silva. Siendo una poesía de gran intimidad, el poeta se encuentra, sin embargo, infinitamente lejos del lector. El piso social compartido se ha esfumado. El lector se enfrenta solo al poema y no encuentra en él explicaciones, al contrario de lo que sucedía con la lírica del pasado, destinada a un lector muy general, no iniciado, para el cual el autor multiplicaba las generalidades explicativas. Si el lector del poema moderno no es también un poeta, si carece de disposición para percibir las alusiones y los matices, las resonancias de una música sin grandes contrastes, sin regularidades ni simetrías obvias, el efecto estético del poema se perderá para él. Pero también la poesía habrá perdido la mayoría de su público. O más exactamente, ya no habrá más público para la poesía. Ésta se habrá convertido en asunto exclusivo para poetas. El lector de poesía es ahora un solitario sospechoso él mismo de escribir poemas en secreto. Y el arte poético de leer pierde toda relación con la declamación en voz alta y la tertulia, tal como se acostumbraba por la época de Silva, en el Mosaico o en la Gruta simbólica, por ejemplo. (Subr. LHV)

Es claro que un asunto como este debe trasnochar a un poeta. Se notan los desvelos de Arango en un momento del ensayo sobre Aurelio Arturo, cuando considera la actualidad de la poesía del nariñense. Era algo a lo que le daba vueltas en la cabeza. Está también insinuado en el título de su ensayo sobre Rogelio: "Una poesía para nuestro tiempo". Cuando fui a verlo utilizó como Silva una metáfora musical para referirse a la dificultad: el raro y azaroso encuentro de un poeta con su lector es "como una concordancia, como cuando en un instrumento, en una guitarra colgada del muro, se toca un acorde y de pronto la guitarra lo repite. Hay una afinidad para ver la poesía”.

Me extrañó siempre que una poesía construida con palabras de todos los días tuviera tanta dificultad para los lectores. Pero así es. Es buena la explicación de Jiménez en la larga cita que acabamos de hacer. Pero no se agota el problema. Quizá todavía amplios sectores del público tengan oídos para esa poesía declamatoria, grandilocuente, que eran en buena parte las de Valencia y Barba. O Tal vez, como dice Arango en la conversación con el cubano (pág. 10), 
la sociedad mundial está creando un hombre que se convierte, como ha dicho Bonnefoy, simplemente en el medio empleado por los objetos para existir, para abundar y sobreabundar. Un hombre así puede pasarse perfectamente sin poesía. También aquí la imprenta podría considerarse como uno más de los medios masivos, cuando multiplica una literatura de mero consumo. La poesía se convierte, así, en un bien que no se vende, que circula casi clandestinamente, y los poetas en una especie de secta marginal.

De cualquier manera la poesía de Arango es una poesía que comparte con la de Bécquer, Silva y Machado la sencillez. Como este último, pensaba que la poesía no está en una frase como "los eventos consuetudinarios que acontecen en la rúa" sino en "lo que pasa en calle". Sencillez, concisión, claridad en el ejemplo del profesor Juan de Mairena. Toda una lección de estilo. También en Dickinson. Una de las traducciones de Arango deja ver la elección y la dificultad ${ }^{180}$ :
La pequeña palabra desbordante
de la que nadie oyéndola, diría
que esconde ardor o lágrimas.
Pero aunque pasen las generaciones,
maduren las culturas y decaigan,
sigue diciendo.

A la reflexión sobre las dificultades se une la consideración de las exigencias hechas al lector. Había leído el poema "Palabra de hombre" como una muestra de las operaciones eróticas del poeta y la palabra. Pero remirando lo que le dice a uno de sus lectores en una entrevista, me doy cuenta de que el mismo Arango veía en ese poema al lector:

Me llamó mucho la atención que usted lee la poesía de una manera muy lenta, muy cuidadosa. Se "pilla" muchas cosas. Por ejemplo... esto: el enamoramiento, la catación del lenguaje que yo creo que es lo que debe tener todo poeta, y que es por lo uno se preocupa. Porque además cuando uno lee un poema lo que está haciendo

180 En mi flor me he escondido. Poemas de Emily Dickinson, Versiones de José Manuel Arango, $\mathrm{N}^{\circ} 1467$, Integraf editores, Medellín, Colombia, 1994, pág. 129. 
es repetir unas palabras, y a veces se aprende versos enteros, fragmentos de poema de memoria, porque uno repite las palabras. En el poema de Fernando González aparece eso de saborear una palabra o una manera de decir. Me parece que usted ve cosas que realmente están en lo que uno ha querido hacer, y uno desea un lector que sea muy cuidadoso con la palabra, que la capte, que la sopese.

Afinidad con el autor. Lectura lenta, demorada. Enamoramiento de la palabra. ¿Es pedir demasiado? ¿Merecen autores como Arango o Machado, para colocar dos muy cercanos al que esto escribe, dedicarles tiempo? El solo hecho que un autor consagre la vida a una tarea merece respeto. Y cuidado. Más aún cuando su obra muestra una aventura espiritual que comparten muchos otros hombres en este mundo tan fragmentado. Pero es más que eso (que ya es mucho): no es una aventura espiritual cualquiera: muestra el empobrecimiento de nuestra época, señala lacras. Y para llevar a cabo esa obra: "pues de 30 a 50 años de ascetismo, sufrimiento y lucha". Y claro está que hay que hacerse la pregunta no solo por el papel que deben desempeñar los críticos sino también los filósofos ante las circunstancias específicas de época. Cuidar estas palabras es curarse del hombre

\section{...el poeta es el adolescente...}

No recuerdo sino un texto de un poeta colombiano sobre un lector: el famosísimo "Leyendo a Silva". Pero ese es un texto que no problematiza la relación. No hay problemas con esa que parece una mujer elegante y que lee a Silva en una edición de lujo:

\footnotetext{
Vestía traje suelto de recamado biso en voluptuosos pliegues de un color indeciso,

y en el diván tendida, de rojo terciopelo, sus manos, como vivas parásitas de hielo
} 
sostenían un libro de corte fino y largo,

un libro de poemas delicioso y amargo.

Debe de haber más poemas. Pero no creo que sobren. Sobran los que tienen que ver con el poeta. ¿Será porque con frecuencia tienen un ego crecido? Cada rato dicen cómo se ven. Poetas serios y bromistas; bufones; embelesados y desencantados. Valencia, según Jiménez ${ }^{181}$, estaba enamorado del tema modernista del poeta enfrentado a una sociedad que odia la poesía y ya no quiere ni puede entenderla. En él los poetas aparecen como la "tribu desolada", y el poeta como "guardián de la belleza escondida en su torre de marfil", "suicida", el que "habita muy alto y mira desde la cima lo vulgar", el que lleva a cuestas lo sagrado; y de manera muy especial: “escultor”, "joyero”, autor de primores artísticos.

Mirar este tema, además de interesante, podría dar lugar a una amplia consideración y larga disertación. Hay visiones del poeta muy atrayentes en Silva, Barba, Rogelio, Luis Carlos López, De Greiff o en Mutis. Y en casos insulares como el Luis Vidales de Suenan timbres. Pero la de Álvaro Mutis es muy sugestiva: parece concentrar todo su esfuerzo poético ${ }^{182}$, si se tiene en cuenta el papel que en él juega Maqroll. En José Manuel Arango, ya hemos visto cómo poeta y lector aparecen desconcertados, en la conversación que tuvo con el cubano Rodríguez Núñez. Esto que, sin duda hace pensar en Silva, parece retomado por Jiménez en un lugar ya citado de su ensayo sobre Arango: "como en Hölderlin, el poeta conserva su función de mediador. Pero es un mediador desconcertado, con más dudas que certezas”.

\footnotetext{
181 "Sobre la presente antología", págs. 23, 24.

182 Esto que insinúa Charry, lo confirma Mutis, quien dijo a G. Sheridan: "El gaviero es el poeta. Esto ya lo pienso ahora; en ese tiempo me pareció que, en el barco en que Maqroll trabajaba, su chamba debió haber sido la de gaviero: es el que ve más lejos y anuncia y ve por los otros" (Citado por Ruiz Barrionuevo, Carmen, "Introducción. Summa de Maqroll: la poesía de Álvaro Mutis", en: Summa de Maqroll, el Gaviero. Poesía, 1948-1997, pág. 9).
} 
Ahora bien, hay dos temas que pueden ser hondos en el poeta antioqueño: uno tiene que ver con Hölderlin; el otro con un tema de Baudelaire, el del poeta como adolescente.

En su poema sobre Hölderlin, se detiene Arango en los riesgos que comporta la ocupación del poeta. Ya me ocupé largamente de ese poema y de ese tema en mi libro. Tomado como poema sobre el oficio de poeta, examino allí un par de textos de Heidegger donde pondera el riesgo: "Hölderlin y la esencia de la poesía” y “¿Para qué poetas?" El segundo texto, titulado con un verso de Hölderlin, tiene que ver con Rainer María Rilke. Aunque los dos poetas interesan en Arango, solo quiero, por brevedad anotar el comentario de Heidegger, en el primero de ellos, sobre un autor que conocía demorada e insistentemente ${ }^{183}$ :

...cuando Hölderlin ha vuelto a casa de su madre tocado por la locura, escribe a un amigo, sobre el recuerdo de su estancia en Francia: 'El violento elemento, el fuego del cielo y la calma de los hombres, su vida en la naturaleza, y su limitación y contento, me ha impresionado constantemente, y, como se repite de los héroes, bien puedo decir que me ha herido Apolo'. (V, 327) La excesiva claridad ha lanzado al poeta a la oscuridad. ¿Hace falta más testimonio de la suprema peligrosidad de su 'ocupación'? El destino más propio del poeta lo dice todo.

Hace poco Cobo Borda comentó este poema, asociándolo a un tema importante en esta tesis, el de la razón. Allí dice que Arango comprueba los ${ }^{184}$ :

...trágicos límites de la razón, como en sus conmovedoras cinco líneas sobre Hölderlin: "quizá la locura es el castigo para el que viola un recinto secreto y mira los ojos de un animal terrible".

Algo sobre este pavor aparece en mi entrevista. Y en el poema que comienza "La noche que reduce la noche a límites".

183 Martin Heidegger, "Hölderlin y la esencia de la poesía", Trad. de José María Valverde, Ariel, Barcelona, 1983, pág. 64.

184 En: "Una década de poesía: 1999-2008” Boletín Cultural y Bibliográfico Banco de la República (www.coboborda.org). 
El otro tema aparece en varios poemas, en un ensayo y una entrevista. Hay un poema de Montañas, dedicado a Elkin Restrepo: "Deslumbramiento" (Pág. 234). Es una metáfora del poeta: niño extraviado por el límite del poblado cuando comienza el anochecer (El poema señala además la apertura de mundos posibles que opera la poesía, lo cual puede estar en el origen del pavor que comentamos hace unas líneas. Para decirnos su "qué-tal-qué", es decir: para mostrarnos que lo que vivimos es solo una posibilidad cristalizada, pero hay que otras, el poema debe asomarse al caos. Para proponer un nuevo orden, debe ir a lo indiferenciado).

Pero ¿es el poeta niño o adolescente? Es posible que Arango le diera muchas vueltas al asunto, pero se queda con el adolescente. En "La poesía es eficaz, nos cambia" está este diálogo:

-Una tesis de Matisse que quisiera me comentaras: "Hay que ver la vida con los ojos de la infancia".

-Qué bello imperativo ese de Matisse. Me parece que es esencial para el artista, para el poeta. Hasta podría sacarse de él una definición: poeta es el que ve la vida con los ojos de la infancia. O tal vez con los de la adolescencia. Baudelaire dice en alguna parte que el poeta es el adolescente. Yo creo lo mismo. El adolescente tiene todavía los ojos del niño, todavía está como descubriendo el mundo. Todo es nuevo para él y como recién creado. Sus experiencias son descubrimientos, como en el niño: el primer amor, el primer poema que lo sacude, la novedad del cuerpo, las urgencias eróticas. Pero además el adolescente tiene un gran sentido de pérdida. Descubre la muerte, la experimenta en él mismo. Tiene apenas 13 o 14 años y ya se le fue el mundo, se le murió el niño. Es como asistir a la muerte propia, una experiencia que según se dice es imposible. El niño no cree en la muerte. La Dickinson tiene un poema muy bello sobre este tema... Sí, yo estoy con Baudelaire. He estado buscando en estos días dónde dice lo del adolescente. Quizá sea una de esas reflexiones que uno lee y solamente mucho después ve claro lo que quería decir.

¿Es por eso que uno de los "Poemas póstumos" se dedica a tematizar al adolescente?: "Ritual de iniciación” (Pág. 307), muestra a un muchacho púber que asiste a la muerte del niño en él: “y él en su rincón se desnuda y observa y palpa su cuerpo/ El cuerpo que ahora le queda estrecho le es extraño le desobedece/ Como si dentro de él hubiera aparecido un extraño/ Otro que medra alimentándose del niño 
que fue/ Palpa y examina los largos brazos las piernas largas y torpes/ Considera su prepucio irritado".

Anterior en el tiempo a estas citas es el ensayo sobre Arturo. Los temas se repiten ${ }^{185}$ :

Tal vez el verdadero poeta -es necesario volver sobre este tema baudelairianosea el adolescente. La niñez es, ciertamente, la época del descubrimiento asombrado del mundo. El niño vive en un presente eterno, vertido en el afuera, fuera de sí. La novedad y la riqueza de las cosas lo atrapan, los ojos se le prenden de ellas. Él es el que ve, el vidente natural. El que puede advertir 'el duendecillo de luz en toda línea' y hacer verdadero un verso como éste:

"Hace siglos la luz es siempre nueva".

La luz, la iluminación. La búsqueda del instante no es quizá otra cosa que el afán de recuperar la riqueza y la nitidez de la visión infantil.

Pero al niño le falta la consciencia de sí. Que está hecha, qué duda cabe, del conocimiento de la muerte. De la muerte propia, en primer término. El niño no cree en la muerte, inventa fábulas para explicarla y desconocerla, los muertos serían impostores que juegan la farsa de su muerte para dedicarse a vivir una vida clandestina, por ejemplo, o para irse a otras tierras.

El adolescente, en cambio, sabe de su muerte y, con este saber, sabe también de sí. Cierto que es imposible imaginar o pensar la propia muerte, porque el yo que trata de pensarla sigue ahí presente. Pero ello no implica que no podamos experimentar la muerte de un modo más decisivo que el del mero pensamiento. El púber asiste a su propia muerte. $\mathrm{O}$, más que asistir a ella, la vive. Es la muerte del niño que fue devorado poco a poco por ese otro que se alimenta de él y se va afirmando dentro. En el cuerpo mismo del púber, cuerpo todavía sin equidad y que se siente ajeno, parece producirse el desdoblamiento que permite la reflexión.

He llamado a este capítulo "Problemas de la lírica". Pero quizá no es el nombre más adecuado. ¿Qué podemos hacer con una novela como De sobremesa? ¿Por qué un proyecto como el de Aurelio -me lo contó Cobo Borda- de hacer una novela épica sobre Cristóbal Colón? Quizá las fronteras entre épica y lírica se diluyen con frecuencia en la obra de los poetas colombianos del siglo XX. Hay que recordar el título del libro - unánimemente considerado malo, por ideológico- de Vidales: La

185 “Aurelio Arturo y la poesía esencial”, en: Aurelio Arturo. Morada al sur y otros poemas, Norma, Bogotá, 1992, pág. 50. 
obreríada. Sobre Mutis, dice Ruiz Barrionuevo: "La poesía de Álvaro Mutis reivindica la épica y lo narrativo en estos tiempos en que la lírica no goza más que de muy reducidos círculos de lectores; pero en contrapartida, lo narrativo de su obra novelesca nunca abandona la intensidad de la lírica, con lo que el tono unitario de su obra se concentra en lo poético”. (Pág. 31) ¿Y qué decir de la obra de León de Greiff?

En el caso de Arango, no he podido saber qué tipo de libro es Montañas. La insistencia en un nosotros que parece hablar ahí, la reivindicación de unos iconos populares de la muerte, me extrañó al comienzo y hasta ahora me intriga. Intriga visto desde el Arango que se sorprende leyendo a Arturo:

Y refleja "nuestro yo/ nuestra tribu". (¿El yo es pues un yo de la tribu según ese "profundo espejo"?)

Deja Jiménez en su comentario de este libro algo cuyos alcances aún no preciso:

Montañas contiene cuarenta y ocho poemas, entre los cuales destaca una secuencia de tres que llevan el mismo título del libro. El autor los coloca estratégicamente: el primero al comenzar el libro; el segundo, en todo el centro; y el último, como cierre del volumen. Otros tres poemas podrían considerarse parte de esta secuencia: "Medida", "En camino" y "Ciudad". Con ellos la poesía vuelve a ejercer su antiguo oficio de maestra de los pueblos. Aquí se nos enseña a mirar, a volver los ojos sobre lo familiar y recuperar sus formas extraviadas en el hábito, su áspera belleza, su sentido arcano: "Casi olvidadas de tan familiares, /casi olvidadas de tan vistas". Ya no se trata del viejo lema rilkiano de aprender a ver. Hay algo más, que trasciende el objetivismo y la distancia impersonal del ojo que registra sin tomar parte. Estas hoscas Montañas "se ensimisman en nosotros"; ni siquiera es seguro que no sean creación de nuestros sueños. El poeta reclama una participación, un tipo de correspondencia muy particular: somos en ellas o son en nosotros, no lo sabemos muy bien. Las reconocemos en nuestra voz, en nuestra forma de caminar, en los gestos. Pero son, ante todo, una manera de ver, una condición de nuestra mirada. (Subr. LHV)

La extrañeza que despierta este libro, por supuesto que alimenta sospechas no solo sobre la obra de Arango sino sobre la condición de la palabra lírica en la poesía colombiana del siglo XX. Y... ese nosotros. Le pregunté a Elkin específicamente por lo nuestro, lo antioqueño en Montañas: "Es muy propio de la tradición poética 
antioqueña: esa afirmación de lo propio, de lo lugareño. Es una tradición que está muy enraizada tanto en la poesía y la literatura, como en el arte. Elige el poeta que quieras y encontrarás una poesía enraizada". 


\section{Preguntas finales}

El recorrido deja ver que la obra de José Manuel Arango ("tremenda reflexión, muy mediada por la dicción poética") permite plantear con cierta hondura temas como el del uso de razón hoy, una relación entre poesía y filosofía propia del siglo veinte, unas relaciones entre poesía y realidad que proponen asuntos que la consideración distraída que le es a uno habitual no deja ver. "Realidad empobrecida". La verdad es que, como decía algún autor que ahora no recuerdo: "Nada es como me lo había imaginado".

En cuanto a la somera mirada hecha a través de los actores del proceso poético - problemas de la poesía, del poeta, de la obra, del receptor- deja ver unos procesos en extremo complicados, que se resisten a dejarse encasillar en conceptos preformados. En uno y otro caso, solo hemos avistado un campo enorme de problemas que, como señalé desde la propuesta metodológica, requiere el trabajo de especialistas. Solo avisté los problemas: pero el propósito era apenas plantearlos.

Ahora bien, este campo enorme aún crece con problemas apenas insinuados, los cuales intento desarrollar un poco en lo que sigue.

Creo que la noción de metafísica, tan recurrente en los críticos y en los mismos poetas (En los textos aquí citados ha sido usada por Machado, Charry Lara, David Jiménez, José Manuel Arango), debe ser tematizada cuidadosamente. Aún no me atrevo a decir en qué sentido estricto la usa Arango. Y ya mostré cómo Jiménez sostiene que hasta el final Arango tiene "aspavientos metafísicos" ¿Tiene en Arango un sentido neto? Lo cierto es que no se asusta ante la palabra. Raro en alguien que es 
poeta y filósofo. Como Machado, la usa en un sentido positivo. Arango dice sí a la metafísica; no a cualquier trasmundo; y choca en esto último con María Zambrano: "No, la poesía tiene también su vuelo; tiene también su unidad, su trasmundo".

Este texto avanzó un poco más sobre la palabra imaginación, cuyo uso sospecho que es un automatismo, una trampa de los preconcebidos, un prejuicio. Si es poesía, dicen las "ocurrencias populares" -Y les creen los críticos y los impensados académicos - tiene que ser asunto de la sensibilidad y de la imaginación. En suma, piel arrozuda, es decir, pelos erizados, y vagabundeo imaginativo. Lo que aquí encuentro en la poesía del siglo XX es una sintonía con la época que no ha sido estudiada. No solo señalé que Arango no usa la palabreja y que Heidegger hace decir a George que la poesía no es cosa de ella (Ni siquiera creo que la no necesidad de la palabra en Arango es solo comprensible por ser la suya una poesía muy próxima a la realidad, que tiene que ver mucho con lo percibido, y con el tiempo presente, con la actualidad: Es verdad que hay que formular la pregunta ¿Por qué en la poesía de Arango predomina tanto el tiempo presente, a diferencia de una poesía como la de "Morada al sur" de Arturo en la que predomina el imperfecto?: "En las noches mestizas que subían de la hierba". ¿Percepción vs recuerdo? Pero esto no resuelve el problema. Es difícil decirlo así porque aunque una poesía se funde en lo percibido inmediatamente, el proceso "constructivo" necesita recurrir al recuerdo. La "reflexión" recuerda la experiencia, se tiene que sumir en ella. El asunto parece más complicado).

Igualmente hice notar que en el caso de la crítica de Charry sobre Mutis, el concepto de imaginación se revela insuficiente: tiene que acudir (¿además?) a la 
noción de "examen de la existencia" para hablar del sentido de la poesía del bogotano. Agrego ahora que en David Jiménez puede ser discutible la interpretación del "Nocturno" de Silva, o al menos los conceptos que ella usa ("Sobre la presente antología", pág. 21):

El "Nocturno" está claramente dividido en dos partes. La primera es una evocación, el recuerdo de un paseo nocturno. Allí las sombras que se juntan pertenecen a dos que se aman, en un momento en el que todavía no los ha separado la muerte. La segunda parece un sueño o un delirio, vivido y narrado como si fuera presente, o al menos en un pasado muy próximo, pues habla de "esta noche", no de "una noche" como la primera parte. Aquí las sombras se enlazan, pero los cuerpos y la almas ya han sido separadas "por el infinito negro" [...] Es la imaginación la que, por un instante, sobrepasa los límites. Si se trata de un éxtasis, no es aquí el éxtasis de la visión mística sino del delirio imaginativo. Una obra poética como el "Nocturno" de Silva busca, quizá, antes que sorprender los asomos de una realidad invisible, pensada y tematizada en el poema, apoderarse de los efectos de encantamiento propios del ritmo verbal, más allá de la significación” (Pág. 21).

¿Es inevitable usar aquí la palabra imaginación, el giro "delirio imaginativo”? Para decirlo en términos de Arango, ¿no se trata más bien, y ante todo, de la "experiencia" de una realidad invisible? La realidad atravesada por el sueño de "La bailarina sonámbula". Ya había mostrado cómo para Arango la experiencia es más "pensante" que el pensamiento y más imaginativa que la imaginación. Lo dice en el caso de la propia muerte, pero lo importante es que muestra los límites del pensamiento y de la imaginación. Cito lo que indica en el ensayo sobre Arturo (pág. 51):

Cierto que es imposible imaginar o pensar la propia muerte, porque el yo que trata de pensarla sigue ahí presente. Pero ello no implica que no podamos experimentar nuestra muerte de un modo más decisivo que el del mero pensamiento.

Esto es muy importante porque María Zambrano muestra cómo parte de lo mutilado por el racionalismo es la muerte. En la página 38 de Filosofía y poesía hay un latigazo: "Porque el nudo está en la muerte. El filósofo desdeña las apariencias porque son perecederas. El poeta también lo sabe, y por eso se aferra a ellas; por eso las llora antes de que pasen, las llora mientras las tiene, porque las siente irse en la 
misma posesión". Vallejo: "Hoy me palpo el mentón en retirada/ y en estos momentáneos pantalones...”.

Este tema de la muerte es de los que pueden dar luces para la crítica del racionalismo y de la manera de entender la poesía; y es un tema insistente en la poesía y en los ensayos de Arango. De Rogelio Echavarría ${ }^{186}$ dice que es un poeta de la muerte:

Rogelio Echavarría es, también, un poeta de la muerte. En su poema "Muerte reiterada" -un título que confiesa una de sus obsesiones, quizá la dominante-, nos dice justamente:

"El poeta es un hombre que

vive y convive con la muerte"

El texto es reciente, escritura de hombre maduro. Pero ya en uno de los primeros de El transeúnte, es decir, en un poema de juventud, había dicho:

"Yo siempre duermo con mi única fiel compañera,

que me acaricia el rostro con sus manos de hollín”

[...] La vivencia de la muerte y la convivencia con ella son, pues, una especie de trato amoroso. La muerte es la única fiel compañera. Su frecuentación es la que mantiene los ojos abiertos: la que, lejos de excluir, permite la ebriedad del canto. Cada hombre debiera aceptar el no saber y la indefensión que su cercanía trae.

Habría que intentar entender lo que significan esta "vivencia", esta “convivencia”. Quizá podríamos por esa vía comprender un poco más lo que está en juego en la extraña ocupación del poeta y hasta quizá los pasos y las "facultades" involucradas en la danza. Pero ¿es "inimaginable" que no intervenga la imaginación? Digamos, siguiendo a Arango, que un poeta no es un escritor, menos uno de los de ficción (Dicho esto sin menoscabo alguno de un trabajo respetable). Escribe uno textos de poesía para intentar entenderse uno mismo. ¿No será que la ocupación del poeta puede brindar a la reflexión maneras de entender mejor lo que sucede en la ficción, en la creación de personajes "imaginarios"? Dejo la pregunta y advierto que

186 “Una poesía para nuestro tiempo", pág. 159. 
los poetas tematizan el asunto mismo de la creación de personajes. Ahí están Serrat y Sabina... A su manera: "Tarrés" o "el pirata cojo".

Otro asunto aquí apenas rozado es el relativo al yo, al "sujeto" (Aunque están las sugerencias de Arango, Francisco José Cruz y de Zambrano). Recuerdo el contexto que sugirió la pregunta por la presencia del ego en la poesía.

LHVT: En la entrevista que usted concedió al cubano Rodríguez Núñez, usted dijo: "La poesía nos enseña a ser... Mejor, a no ser". Yo vi ahí una conexión con Heidegger.

JMA: Es posible... Es posible...

LHVT: ¿Qué querría decir usted con esa frase?

JMA: Puede ser en el sentido de renunciar al ego y a todas esas cosas y abrirse uno de otra manera (Muy humilde) a las cosas, al mundo, a la belleza del mundo, a los diosecitos... y no tener pretensiones, en primer lugar la gran pretensión de ser inmortal, de que después de esta vida hay un premio que da un Dios. Tal vez vaya como por ese lado.

La frase con la que comienza esta parte de la conversación ha sido una de las que más me han hecho pensar. Sin llegar, creo, a resultados satisfactorios. Me ha servido mucho el vaciamiento de que habla María Zambrano. Sirve mucho la consideración hecha acá sobre la noción de experiencia en Arango. Luminosa es para Cobo Borda la consideración de Arango sobre la "evaporación del yo”, y puso en la contracarátula de su Antología de la poesía hispanoamericana algo sobre el tema:

La poesía -escribe T.S. Eliot en El bosque sagrado- no es un derrame, sino un escape de la emoción; no es la expresión de la personalidad, sino un escape de la personalidad. Sólo los que tienen personalidad y emoción saben lo que significa escapar de ellas.

Quizá la última frase resultó algo así como un preciosismo, uno de esos de los que quería librarse el Eliot de Función de la critica, función de la poesía, en el apéndice 
lleno de ponderación y luz, donde también está esa frase que resume la experiencia de poeta en el siglo XX: "Ser poeta no es una profesión sino un juego de tontos".

Liberarse del ego puede tener acá varios sentidos. Librarse de la prepotencia, claro, la vanidad. Este sentido aparece en mi entrevista con Arango (Es inevitable que no se hinche el yo con los reconocimientos, y no obstante debe evitarse el envanecimiento... que es un ruido para la comprensión de nuestra condición). Pero creo que llega más allá: hasta donde comienza la sospecha por la "ficción del yo". O al menos a la sospecha de que no necesariamente está en todo el proceso de la poesía de Arango. Quizá cuando la vista del poeta se fija temáticamente, percibe, lo que pasa mucho en la poesía de Arango, sea indispensable hablar de constitución de sujeto, es decir que puede aparecer el yo en alguna parte de la reflexión, respuesta a la experiencia. Pero no siempre. En esto ayuda el testimonio de Mutis citado ya:

Un rostro, un gesto, un tema musical, escribe Mutis en 'Sonata', 'vuelven un día a visitarte', llaman de otro tiempo y quizá estén a punto de decir 'con unos labios sin voz, la palabra que tal vez iba a salvarte'. Son anclas que revuelven las profundidades

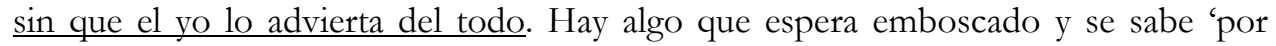
cierto sordo dolor que cierra el pecho' (Subr. LHV).

La experiencia poética puede ocurrir a espaldas del yo. Ahora bien, en varios lugares David Jiménez, al comienzo de su ensayo sobre la poesía de Arango (pág. 101) parece percatarse de que hay "algo raro" en ella en lo concerniente a la relación entre sujeto y objeto:

La tentación de la identidad es grande en esta poesía. Permanentemente nos encontramos con las huellas de un mundo anterior a las diferencias conceptuales y a la separación entre objetos y sujetos:

\footnotetext{
"los sueños del musgo en las rocas

amarillas, recuerdos

del polvo, que repite

antiguas formas
} 
y por la playa difícil

el cangrejo, como un oscuro signo

del mar"

Es difícil decir si en los versos citados hace falta un sujeto humano o si, por el contrario, "los sueños del musgo", por ejemplo, expresan la humanización de la naturaleza, su recuperación como objeto propio de la lírica y la trasmutación de lo sujetivo en objetividad. El culto rilkiano a las cosas, la celebración de su autonomía con respecto al sujeto, es la vía privilegiada mediante la cual la cual se distancia la poesía y toma partido en contra del dominio técnico sobre la naturaleza. Es también como en el poema se conjura la imagen de una vida libre.

Hemos visto cómo Arango piensa en contacto con el poema de Arturo:

Y es "moneda de sol". Y refleja "nuestro yo/ nuestra tribu". (¿El yo es pues un yo de la tribu según ese "profundo espejo"?) Y es "monólogo mudo" pero también diálogo.

Si la lírica es expresión del yo, ¿Qué pasa cuando el yo es el de la tribu? El nosotros ya había sido reiterado, machacado, en otro ensayo, en el de Rogelio (pág. 158):

Entre nosotros hay quizá una visión burlona de la muerte. Y tal vez nos venga - a nosotros, tan encerrados entre estas montañas- de la Edad Media, a través del medieval catolicismo barroco de la Contrarreforma (El gran teatro del mundo, de Calderón, es sin duda una versión para auto sacramental de la vieja Danza de la muerte).

Quedan entonces estos temas a examinar en extenso (nociones de metafísica, de imaginación, de sujeto... Agregó: secularización) temas que quizás no tengan un desarrollo suficiente para permitir un planteamiento más cuidadoso o que apenas advierto ahora, cuando propongo la tarea de un examen filosófico. Al tiempo que se hace preciso plantear de manera más desarrollada el examen de los asuntos que ha planteado esta tesis (razón, filosofía, realidad, "Problemas de la lírica") en la poesía colombiana del siglo XX. Lo hecho aquí es apenas esbozo. 
El método aquí propuesto me parece que puede ser bastante fructífero, a condición de que puedan ser precisadas aún más sus limitaciones. Es necesario ahondar más en la dimensión metodológica. Comienzo apenas a discutir con Blumenberg. Es posible, por otra parte, concluir que sí es muy fructífero el método seguido: acudir a los poetas. En esto coincido plenamente con las clases del doctor Molinuevo en Salamanca... En esto y en la sospecha por los conceptos venidos de la filosofía, particularmente la racionalista.

La elaboración de este trabajo en perspectiva filosófica me dejó ver problemas que no había visto. Así los reseñados en esta especie de conclusión. Ello a pesar de que este trabajo se basa en una lectura muy lenta y dilatada en el tiempo. Así debe ser: una lectura lenta que se ciña a las obras. Sobre todo cuando es tanto lo que está en juego. Sin hacer otra cosa que lo que enseñó Sócrates: intentar entender lo que decimos cuando hablamos. 


\section{Apéndice}

\section{Conversación con José Manuel Arango}

Este es un fragmento de una entrevista que tuvo lugar un fin de semana de 2001, momento en el cual conocí personalmente a Arango, gracias a un escrito mío sobre su libro poemas reunidos.

Una larga conversación sobre poesía comenzó en el viaje de Medellín a Copacabana, en el carro conducido por José Manuel. De esa charla solo quedó este registro (una hora) grabado en una casita de campo de esta última población. Naturalmente se perdieron muchas cosas (aquellas de las que se habló antes y después de grabar: por ejemplo, lo referente a poetas fundamentales como Silva y Arturo y Rubén Darío). Con cierta incertidumbre, afirmo que daba vueltas en la cabeza de José Manuel Arango la "Canción ligera" de Barba, una reflexión sobre la poesía de este gran poeta antioqueño. (Quisiera que en esta transcripción quedara esa manera suya de hablar con acento lugareño, insistiendo a veces en ciertas palabras, esa manera de hablar meditativa en busca de la palabra precisa).

Luis Hernando Vargas Torres (LHVT): Ya le comenté que me interesa la relación suya con Martin Heidegger: ¿Cómo está Heidegger ahí, en su obra poética?

José Manuel Arango (JMA): Como profesor de filosofía nunca trabajé a Heidegger, pero siempre me interesó. Como le decía, yo traté de "meterle el diente" a Ser y tiempo. Y lo leí, lo releí, durante un tiempo más o menos largo. Realmente el Heidegger que más me ha interesado a mí es el de Caminos del bosque (Sendas perdidas). Por ejemplo, su visión de Nietzsche, de la muerte de Dios, de la relación de la muerte de Dios con el superhombre (Con lo que según Heidegger es el superhombre para 
Nietzsche). Me interesa esa actitud ante la vida que es capaz de vivir sin dioses... o sin Dios (Mejor que sin dioses, sin Dios), porque es afrontar la vida frente a la muerte, "ser-para-la-muerte", como dice Heidegger, sin pensar en otra vida, inmortal. Lo cual no implica que uno niegue los dioses. Tal vez ellos huyen por los monoteísmos...

Ahora están los tres monoteísmos, ahí agarrados, tratando de destruir el mundo. Ahí tenemos a Bush, a los fundamentalistas musulmanes y a los judíos. Son las tres religiones monoteístas las que están haciendo el mundo invivible; porque los pueblos politeístas, como los romanos, nunca fueron fanáticos, aceptaban otros dioses y les era posible tener diosecitos por todas partes y para todo.

Para volver a Heidegger: su crítica del monoteísmo, cuando Heidegger dice que la “desdivinización” o el “desendiosamiento” empezó con el monoteísmo, ha sido importante para mí. Por otra parte, su visión de la poesía y cómo Heidegger lo lleva a uno a Hölderlin, lo lleva a Trakl, lo lleva a Rilke (a cierto Rilke: el de las Elegías y de los Sonetos a Orfeo). Sí, yo sé que Heidegger es un filósofo muy difícil, que uno nunca puede llegar a decir que entendió; pero le toma ciertas cosas que le llegan a uno, que lo marcan y ya están en uno, de alguna manera...

Con Schopenhauer, con Nietzsche, con Heidegger tuve una relación muy personal, que nunca toqué en mis cursos de filosofía. Mis cursos de filosofía eran sobre el lenguaje, pero desde otra perspectiva.

LHVT: En la entrevista que usted concedió al cubano Rodríguez Núñez, usted dijo: "La poesía nos enseña a ser... Mejor, a no ser". Yo vi ahí una conexión con Heidegger.

JMA: Es posible... Es posible... 
LHVT: ¿Qué querría decir usted con esa frase?

JMA: Puede ser en el sentido de renunciar al ego y a todas esas cosas y abrirse uno de otra manera (Muy humilde) a las cosas, al mundo, a la belleza del mundo, a los diosecitos... y no tener pretensiones, en primer lugar la gran pretensión de ser inmortal, de que después de esta vida hay un premio que da un Dios. Tal vez vaya como por ese lado.

LHVT: En mi ensayo “'Cosas a un tiempo familiares y ajenas'. La aventura de la palabra en José Manuel Arango", traté de evitar a toda costa hacerme la pregunta: ¿cuál es el mundo poético de José Manuel Arango? Preferí formular la pregunta de una manera imprecisa: ¿cuál es la otra parte adonde nos arrebata esta poesía? Quizá, entre otras cosas, porque para la poesía tan importante como el cosmos es el caos, tan importante como el orden es el desorden.

JMA: Sí. La parte de la noche, de la oscuridad, de la muerte es fundamental...

LHVT: Hace un rato usted me decía que Barba tiene un lado saturnal que ya no es convincente. Pero ¿no tiene eso que ver con una intuición profunda por parte de Barba de ese caos?

JMA: Bueno. Tal vez en ese sentido sí. Por ejemplo, la "Canción de la vida profunda", una de las más bellas, es evidentemente sobre el erotismo y sobre la muerte. Yo digo que hay una cierta visión (Demasiado romántica) del poeta como un elegido, como un profeta, como un maldito, en ese sentido demoniaco de tener la huella de Saturno en las sienes. Todos tenemos por supuesto el lado oscuro, sí; pero esa visión del poeta como alguien que es como un anunciador la hemos dejado de lado. Es muy significativo que otro poeta, de Santa Rosa de Osos también, como es 
Rogelio Echavarría, unos añitos después de la muerte de Barba formula la visión del poeta que es la que yo comparto y creo que muchos compartimos hoy día. Es el poeta como transeúnte, como alguien que va entre todos y al lado de todos y con todos, porque fundamentalmente no se distingue de los otros hombres: no tiene ninguna misión que le haya sido encomendada por el demonio ni por Dios ni por nadie, sino que es una persona común y corriente que tal vez se ha parado a preguntarse por las cosas, por la vida, como todos en algún momento nos preguntamos, por otra parte. Porque toda la gente, aun en un mundo como el que vivimos, en el que hay estar pendiente es del pan, de las cosas materiales (y muchas veces en eso se le va la vida a mucha gente), sin embargo ante una muerte de una persona cercana, ante un enamoramiento o una experiencia especial, dolorosa o alegre, todo el mundo se pregunta por la vida. Entonces, el poeta no se distingue. Tal vez... tal vez está más atento a esa parte... (¿Cómo podríamos llamarla?) mágica o sagrada de la vida. Pero no hay una diferencia. En ese sentido es que digo que la visión de Barba es todavía un poco la del poeta romántico. Hoy día tenemos una visión mucho más pedestre, si se quiere, del poeta. Como transeúnte. Tal vez eso es lo que me atrae a mí de la poesía de Rogelio.

LHVT: Él es uno de los contados poetas de quien pone epígrafes, y eso en Montañas...

JMA: Sí. En Montañas quise dedicar a algunos amigos unos poemas (No he tenido la costumbre, no sé por qué) o hacerles un pequeño homenaje con algún epígrafe, como lo hice con Mutis, con Elkin Restrepo, con Rogelio.

LHVT: En mi ensayo busqué una palabra para definir la intención de su poesía. Y terminé escribiendo a la manera de Paz algo así como: Arango: mujer que es noche 
que es lluvia que es agua que es... Si es eso, es algo monstruoso lo que se está diciendo con esa expresión. ¿Eso puede ser la voz del Caos?

JMA: Sí. Sí. Pero es que la idea de que existe Dios es la idea de que existe el orden. Si no existe un Dios no existe ni orden ni un sentido trascendental de la vida, y la vida es azarosa... Lo que sucede es que hay maneras de acercarse a eso. Hay maneras muy dramáticas. En Barba hay una manera dramática. Yo tengo una manera más tranquila, sin que eso deje de causar a veces incluso pavor. Pero sin ahuecar la voz, sino aceptar de una manera casi budista, casi oriental, la falta de sentido de las cosas y cómo el sentido se lo tiene que dar uno mismo, y hacer su propia vida, darle un sentido, porque sentidos trascendentales no hay. Algo como eso. Pero sin dramatismo, sin alzar demasiado la voz...

LHVT: ...y sin ser tan "teatrero" como Barba...

JMA: Digámoslo así. Por otra parte, como hablábamos ahora, a pesar de cierta retórica modernista o postmodernista en él, y de palabras un poco rebuscadas, uno siempre vuelve a él (Se puede quedar años sin leer a Barba) y siempre le toca alguna fibra. Eso es lo maravilloso de Barba. A pesar de su visión del poeta, a pesar de su visión dramática y a veces un poco retórica de las cosas. Sin embargo uno sabe que es verdad lo que está diciendo, que viene de muy adentro, que realmente es una cosa sufrida y vivida y que su voz es como la de ciertas voces de cantantes de jazz que nacen como desde las entrañas. Sí. Sí. Barba de todos modos es un poeta que uno quiere...

LHVT: Como quiere a Vallejo... 
JMA: ¿Bueno...! A Vallejo lo quiere uno más, sin duda. A Vallejo yo al menos lo quiero más. Me quedo, a veces, años sin volver a leer a Barba, lo que no me pasa con Vallejo, a quien con cierta frecuencia uno vuelve. Por lo menos a algún poema. Se acuerda de un poema; va, lo busca. Lo vuelve a leer. Sí. Vallejo sí, sin duda, es uno de los grandes poetas que tenemos.

LHVT: Usted decía, en entrevista concedida a Babel, que le interesaba sobre todo el Vallejo de Poemas humanos.

JMA: Yo pienso que es el mejor libro de él, el gran libro de la madurez, digamos. Los heraldos negros son todavía... Uno no ve ahí todavía su voz. Ya hay poemas allí que son Vallejo, pero hay otros que todavía no son él. Ahora, Trilce es como la búsqueda, pero a veces hay gratuidades. Toda esa pirueta, ese juego con la lengua (porque son piruetas, pero piruetas metafísicas, digamos, las que hace con el tiempo, con la persona, con el yo, con todo..., con el lenguaje mismo). Trilce es como un libro de transición; en cambio en Poemas humanos uno ya no encuentra gratuidad. Todo ese trabajo dice cosas. Cada pirueta... Alguien (No recuerdo quién) lo ha comparado con Chaplin. Y en realidad él tiene algo como un humor chaplinesco en esas piruetas de lenguaje que hace.

LHVT: ¿Se puede hablar de un erotismo en Poemas humanos?

JMA: Exacto. Y sobre todo cómo trabaja Vallejo con el cuerpo. En ese sentido me llama mucho la atención la comparación con Chaplin. ¡Cómo trabaja con el cuerpo!: que "un paria duerme con el pie a la espalda" o "un hombre pasa con un pan al hombro” o... ¡bueno!... Ya no hay gratuidades como en Trilce, donde de pronto hay cosas que se quedan como en esbozo, un poco en el aire. 
LHVT: Para volver al pavor, al caos, a la "otra parte” que se abre en su poesía...

JMA: Pero usted dice de pronto en algún momento en su ensayo que a lo mejor es una...no sé si idea o una tendencia como a la armonía... Entonces puede ser eso. Yo tal vez no insisto demasiado en el caos. Lo veo, lo acepto, pero siempre retorno a buscar una armonía que no implique una visión sistemática del mundo, sino una armonía en la belleza, un poco en el sentido nietzscheano de que la vida es posible sólo como estética.

LHVT: Usted insiste mucho en la armonía. ¿Sabe que me gusta mucho ese adjetivo suyo del poema "Armonía": "perdido/ por los ciegos senderos/ de la música// tienes/el rostro/ que tendrás en la muerte? Ese adjetivo "ciegos" es precioso. Me dije que de pronto el punto de partida, la anécdota, del poema es sencillo: uno para oír música habitualmente cierra los ojos, pero ese adjetivo ahí colocado abre a... abre mucho. Ese "ciegos" es de una ambigüedad valiosísima.

JMA: Me llamó mucho la atención que usted lee la poesía de una manera muy lenta, muy cuidadosa. Se "pilla" muchas cosas. Por ejemplo... esto: el enamoramiento, la catación del lenguaje que yo creo que es lo que debe tener todo poeta, y que es por lo uno se preocupa. Porque además cuando uno lee un poema lo que está haciendo es repetir unas palabras, y a veces se aprende versos enteros, fragmentos de poema de memoria, porque uno repite las palabras. En el poema de Fernando González aparece eso de saborear una palabra o una manera de decir. Me parece que usted ve cosas que realmente están en lo que uno ha querido hacer, y uno desea un lector que sea muy cuidadoso con la palabra, que la capte, que la sopese. 
LHVT: Lo que dice su poema "Palabra de hombre": "La palabra/ como una moneda/ sopesada en la palma, //lanzada contra el muro de piedra/ para oír su timbre,// mordida/para saber su ley"...

Bueno: hay una cosa que quiero preguntarle sobre "La bailarina sonámbula". Usted menciona ahí en ese poema a Lezama, pero supongo que ahí está también Valéry.

JMA: En el momento en el que yo escribí eso, no era consciente. Pero después precisamente David Jiménez me hizo caer en cuenta (en un articulito muy cordial que escribió a propósito de ese texto) de que es realmente la misma visión de la poesía de Paul Valéry... Pero de pronto yo no le había puesto cuidado al Valéry teórico...

LHVT: Y no lo había leído usted...

JMA: No, yo no lo había leído...

Ahora: me llama mucho la atención que, en el rato que hemos hablado, coincidimos en la apreciación de los poetas. De Vallejo. De Paz, porque para mí también "Piedra de sol” es el gran poema de Paz, y a mí me llegó mucho cuando lo conocí. Coincidimos también en lo de Barba. Es decir hay una cierta afinidad; tal vez por eso me emocionó tanto leer su ensayo, porque vi que había como una concordancia, como cuando en un instrumento, en una guitarra colgada del muro, se toca un acorde y de pronto la guitarra lo repite. Hay una afinidad para ver la poesía.

LHVT: Creo que lo que pasa es que usted me ha formado. Lo he leído creo que durante catorce años. No sé quién me lo acercó, pero fue quizá en un momento en que leía intensamente a Vallejo. 
JMA: Pero de todos modos la afinidad tenía que existir de antemano. Uno escoge los poetas porque encuentra cosas de uno en ellos. En mi caso, por ejemplo, Vallejo, Machado, Emily Dickinson... Creo que tiene que haber una afinidad previa.

LHVT: Hay cosas de la vida. Por ejemplo, yo también fui militante. No anduve en el Seminario, pero estuve interno. Yo también tuve mi Luis Carvajal. Puede haber cosas como esas... Cosas muy raras.

JMA: Que uno nunca es capaz de esclarecer. Son cosas muy oscuras, que vienen quién sabe de dónde y que no vale la pena tampoco esclarecer, porque se enloquecería uno si tratara de aclarar todo y dejar el mundo sin oscuridad.

LHVT: Me llama la atención la unanimidad que empieza a haber en torno a su obra en el país. Ya hay palabras mayores como las de Álvaro Mutis. Uno ya ve que cuando hacen una reseña de obras poéticas significativas en el país siempre está Arango.

JMA: Uno no está muy pendiente de esa cosa, pero de todos modos es halagadora. Hay cierto ego que nunca se puede matar del todo, porque si fuera fácil matarlo no existirían las técnicas que hay que llevar toda la vida como el budismo. Los premios no le interesan mucho a uno, pero hay "premios" que sí son muy bellos. Por ejemplo, cuando publiqué Signos, un amigo me llama un día. Yo estaba en la casa. Me llama desde un motel y me dice: “-Aquí estoy con una muchacha. Estamos leyendo tus poemas y haciendo el amor". Si la poesía sirve para eso, bienvenida... O encuentros que uno tiene como este con usted. Son los mejores premios.

LHVT: Pues para mí es un premio... 
JMA: Y para mí... Para mí también. Yo creo que uno es como un artesano. Uno ve cosas muy bellas, muy bien hechas, poemas muy bellos, muy bien hechos y entonces a uno también le dan las ganas de hacer una cosa de esas. Y cuando hace un poema y queda satisfecho, dice "-¡Eh! Creo que esto es bello". Y hasta ahí llega uno. Claro que uno publica. Y no sabe en qué irá eso o adónde llevará. Pero lo que uno busca primordialmente es como ponerse uno mismo en claro, y hacer eso, ponerse claro, a través de hacer como una artesanía. Que uno quede bien con uno, que se sienta a gusto. Como se siente un artesano cuando hace un caballito de madera, un juguete... Lo otro es adjetivo realmente.

LHVT: Su poema de la moneda marcada con la uña... Ahí vi yo el poema de Cernuda “A un poeta futuro"... El verso "Que otros ojos compartan lo que miran los míos”, podría ser el epígrafe de su poema.

JMA: Claro.

Yo a Cernuda lo admiro; me parece un tipo muy lúcido. Pero por alguna razón no ha sido de mis poetas de cabecera. Lo he leído; lo encuentro más cerebral que afectivo (No es como Machado); a veces lo encuentro como áspero, como poco musical. Entonces, puedo decir que no conozco mucho a Cernuda. No que lo desconozca. Es uno de los poetas más lúcidos, más adelantados a su época en esa generación del 25. Es cuestión de afinidad; pero lo admiro mucho.

LHVT: Y ¿cómo siente usted a Guillén, a Jorge?

JMA: ¡Ah! Guillén sí. A mí Guillén me parece uno de los grandes poetas del siglo pasado en la poesía española. Sobre todo por esa... (No sé quién, hablando de él, lo decía)...esa dura alegría o duro júbilo. Eso es lo que uno encuentra en él. Es una 
celebración de todo, una alegría frente a todo, pero nunca tonta, nunca blandengue. No. Una rudeza... Sí. Es un poeta que a mí me parece muy raro, porque la poesía desde Baudelaire ha insistido mucho en... La poesía de Mutis insiste en la putrefacción, como la poesía de Baudelaire. Yo creo que Mutis es muy baudelairiano en ese sentido. Ese poema a la carroña de Baudelaire. Con eso inició una cosa que uno encuentra en Mutis. Entonces el caso de Guillén es un caso muy raro en el siglo XX.

Ahora: Cántico era la "cuerda" de él, porque después escribió ese otro libro (¿Cómo se llama?) ya sobre toda la parte política de la guerra civil... Y no lo recuerdo posiblemente porque ya no era Guillén, ya estaba hablando de otra cosa que no era de su temperamento. Para hablar de esas cosas duras es mucho mejor Cernuda.

LHVT: Hay una cosa muy complicada con los poetas. Por ejemplo, en el caso de Mutis. A mí me gusta mucho Mutis. Pero aparte de la de Baudelaire hay en él una marca fuerte de Zalamea.

JMA: O del Perse de Zalamea...

LHVT: O del Perse... Cierta suntuosidad que a mí me aparta un poco de Mutis.

JMA: Pero sabe qué... Yo no sé... Zalamea tenía una retórica muy hueca. Pero cuando se pone a traducir a Perse, es como si ese impulso se encauzara: él logra como... una medida, como unas proporciones... Son espléndidas las traducciones de Saint-John Perse. Yo creo que lo queda de Zalamea son sus traducciones de Perse. Yo creo que más que venir de Zalamea viene de Perse ese ritmo caudal. Sí; a mí no me suena hueca esa entonación de Mutis. Me parece que ese ritmo caudal juega muy 
bien con sus ríos crecidos del trópico, con esa desmesura de Maqroll, y detrás de eso hay una visión del mundo que es muy lúcida, muy bella.

LHVT: Será por la sobriedad suya, por la sobriedad de Machado ("Un golpe de ataúd en tierra es algo perfectamente serio”), que me aparto ahí de Mutis. Claro que es espléndido eso de: "Esta noche ha vuelto la lluvia sobre los cafetales".

JMA: Pero mire que hay un tono que es ceremonial y que se encuentra en "Moirologhia" o lo encuentra uno en Jaime Jaramillo en "Aviso a los moribundos" (X en el poema incluso usa la segunda persona del plural): “A vosotros, los que en este momento estáis agonizando en todo el mundo:/ Os aviso que mañana no habrá desayuno para vosotros"... Hay una cosa ceremonial que es muy linda. No sé. Yo siempre prefiero una poesía muy escueta, pero ese tono ceremonial o el tono caudal de Mutis a mí me llega. No lo siento hueco.

LHVT: A mí me gusta mucho Mutis. Por poner un solo ejemplo, el "Nocturno en Al-Mansurāh" es espléndido, pero a veces me pasa como... ¿Usted cómo se lleva con Borges?

JMA: Me encanta...

\section{LHVT: ¿Sí? ¿El poeta?}

JMA: Pero es que yo creo que Borges es poeta en todo lo que escribe. Borges me parece muy ceñido. Creo que Borges le enseñó a la poesía hispanoamericana a no ser "pajuda", a decir las cosas con las palabras esenciales. Pero ¿qué impresión tiene usted? 
LHVT: Yo soy amante del Borges de los relatos, del Borges narrador. Pero con los poemas no puedo. Hace un rato, cuando usted dijo que mientras Clara va a misa usted se va a leer un periódico, me acordé del poema a Whitman, ese que comienza: “El olor del café y de los periódicos...” No le he podido entrar...al Borges poeta.

JMA: Bueno. Menos mal que tenemos un primer desacuerdo. Nos estaba haciendo falta.

Yo siento que Borges es poeta hasta en las entrevistas. Si la poesía es un lenguaje que no se deja llevar del impulso, sino que es preciso, exacto, Borges es poeta siempre, hasta en las entrevistas, en los cuentos y en los ensayos. Pero, de todos modos, si a mí me pusieran los relatos y los ensayos y me pusieran los poemas, yo me quedaría con los poemas. Es un poeta muy cerebral. Pero en el caso de Borges lo cerebral no deja de ser conmovedor. Por supuesto que no digo que en todos sus poemas. Usted acaba de citar algo que suena un poco retórico. Pero por ejemplo se podía citar ese poema donde se habla de esa cierta falsedad de fondo que hay en toda literatura (Mientras la realidad está allá, estoy yo aquí hablando de ella) y que termina: “y hombres de labios podridos que sienten frío en los dientes". Ante poemas como ese uno se queda frío. $O$ ese poema que le dedica a un teólogo y clérigo norteamericano (“y en el centro puntual de la maraña”), un tipo que no predicaba sino el infierno, uno de esos como fundamentalistas protestantes que trabajan a base de miedo... Y el "Otro poema de los dones", ipor Dios!, donde empieza a dar gracias por un mundo de cosas. Da gracias por "Verlaine, inocente como los pájaros", da gracias por san Francisco que ya escribió el poema, da gracias porque el poema no se puede escribir y entonces estamos tratando de escribirlo, da gracias por "Schopenhauer que quizá descifró el universo", da gracias por el "lenguaje, que 
puede simular la sabiduría”. Da gracias... ¡No! Ese poema a mí me tumba. Fernando González usaba esa expresión, "me tumba": una cosa que lo deja a uno pasmado. "Me tumba". O ese "Poema de los dones": "Nadie rebaje a lágrima o reproche/ esta declaración de la maestría/de Dios, que con magnífica ironía/ me dio a la vez los libros y la noche".

LHVT: ¿Y el tono de ese poema? ¿La andadura es como... como muy modernista?

JMA: No. No. Él viene del modernismo, por supuesto. Lo ha dicho él mismo. Él viene de Lugones, de Darío. Luego, después de su periodo juvenil, de su movimiento de vanguardia, se zafó de todo eso. Y volvió a hablar de Lugones, de Darío; pero evidentemente en Borges no hay la retórica modernista.

\section{LHVT: ¿Y Eliot? ¿Los cuatro cuartetos?}

JMA: Son muy buenos Los cuatro cuartetos... La tierra baldía... Eliot es un gran poeta.

\section{LHVT: ¿Y el crítico?}

JMA: Como crítico no lo conozco mucho. He leído la poesía de él... Pero hay algo que no me gusta. Le iba a decir que Los cuatro cuartetos son maravillosos. Y un poema como "Miércoles de ceniza". O "El viaje de los magos". Pero en el fondo hay una antipatía por esa posición de Eliot de ser anglicano en religión, clásico en poesía...; en cambio me quedo con William Carlos Williams que hasta lo último no quería ser clásico, quería ser otra cosa distinta, quería cambiar la poesía en lengua inglesa, con Pound... Y Eliot como que los acompañó un tiempo. Pues La tierra baldía se la mostró Eliot a Pound, para que le echara "tijerita". A mí me fascina esa actitud 
siempre fresca de Williams frente a esa actitud como autoritaria, dogmática de Eliot.

Pero eso es un poco al margen; porque "El viaje de los magos", que es un poema religioso, es un poema hermoso...

Copacabana, 17 de noviembre de 2001 


\section{José Manuel Arango. Conversación con Elkin Restrepo}

Luis Hernando Vargas Torres (LHVT): Cuando le dije que quería conversar con usted a propósito de Arango, me respondió que era la persona menos indicada. Pero he topado lo siguiente. Casi en cada una de las entrevistas hechas a José Manuel aparece Elkin Restrepo. Más: una de las frases que hay en la "Nota autobiográfica" del 2002 es la siguiente: “Ahora soy profesor jubilado de la Universidad de Antioquia y sobrevivo en Medellín, donde con algunos amigos publicamos la revista DesHora". Más todavía: en la entrevista que le hizo la revista Babel, Arango decía que había tenido la fortuna de escribir ensayos sobre poetas que quería. Menciona a Rogelio Echavarría, Álvaro Mutis, Jaime Jaramillo Escobar, Elkin Restrepo y Aurelio Arturo. Finalmente, José Manuel, que parece muy poco dado a los epígrafes, puso cuatro en Montañas: uno de Rogelio Echavarría, uno de Álvaro Mutis, uno de Elkin Restrepo y uno de Constantin Kavafis. Entonces, parece que la presencia suya al lado de José Manuel es una presencia sumamente importante.

Elkin Restrepo (ER): Conocí a José Manuel en el año 1969, cuando me vinculé a la Universidad de Antioquia como profesor de Literatura en el Departamento de Humanidades de la Facultad de Ciencias y Humanidades. Allí me encontré a José Manuel, o lo advertí, por una casualidad. Alguna vez, al entrar a la sala de profesores, él estaba sentado en su escritorio, leyendo el libro Los poemas de la ofensa, de Jaramillo Escobar, un libro que editó Tercer Mundo, y que él me regaló, supongo, porque aún lo tengo. Encontrar en la Universidad a alguien también interesado en la poesía, no era muy común en aquel entonces. Yo ya había iniciado mi trabajo de poeta hacía algún tiempo y había comenzado a publicar. 
José Manuel era una persona muy silenciosa, discreta y reservada, pero con unas copas en las reuniones familiares y de amigos se tornaba muy efusivo y cercano, incluso conversador, lo que es casi un disparate. Existía en él un espíritu festivo que, cuando se daban las circunstancias, lo hacía un buen compañero de farras.

Claro que en alguna ocasión, en Bogotá, cuando le hicieron un homenaje en la Javeriana con motivo de sus sesenta años, -lo que es la memoria- él dice lo contrario, que fue él quien se me acercó, algo que no iba con su temperamento. Por supuesto que fue al revés; esa memoria sí la tengo muy clara. Todavía lo recuerdo sentado en su cubículo, leyendo el libro; y mi curiosidad por alguien que, siendo profesor de Lógica, prestaba atención a la poesía.

A partir de allí, se inició una amistad por más de treinta años.

En aquel entonces José Manuel no había publicado. En el año 70 editamos acá en Medellín un pequeño libro varios poetas: Juan Gustavo Cobo Borda, Darío Jaramillo, Henry Luque, Álvaro Miranda y yo, con el nombre de „iOhh!!, un título muy propio de la época. Una tarde le pedí que me acompañara a la editorial a recoger unos ejemplares. En algunas entrevistas, él rememora -no sin cierto lirismo- ese momento: el olor de las tintas, del papel, el sonido de los linotipos; en fin, todo aquello que a un escritor le despierta la atmósfera de una imprenta. Igualmente, a mí me tocó acompañarlo, más tarde, sin tanta atmósfera, pues se trataba de una oficina común, cuando publicó su primer libro, Este lugar de la noche.

Mira: yo no sabía, ni me sospechaba que él escribía, nunca había dicho nada al respecto; hasta entonces su condición era la de un gran lector de cuanto libro circulaba. En esa discreción suya -no exenta de astucia-, hasta que no estuvo bien 
seguro de lo que escribía y tener listo su primer libro, no mostró nada a nadie, sé por qué lo digo. José Manuel tenía ya treinta y cinco años, no lo olvidemos. En todo caso, una mañana, mientras tomábamos un café en la Universidad, me entregó algunos escritos, pidiéndome la opinión. Para mí fue una sorpresa y un deslumbramiento (uno de ellos lo coloque como epígrafe de mi libro Lugar de invocaciones). Por primera vez este amigo con el cual compartía muchas cosas desde hacía algún tiempo me mostraba sus textos. Luego me dijo que tenía ya un conjunto. Me lo dio a leer, manifestándome el interés de hacerlos publicar. Recuerdo que una mañana del año 73 lo acompañé a las oficinas de la Oveja Negra, situadas en la Avenida Primero de Mayo, donde por cinco mil pesos contrató la publicación del pequeño libro. Recuerdo que el diseño de la portada lo hizo Fernando Granda, quien era en ese entonces el director de la editorial acá, en Medellín. El libro, por supuesto, era Este lugar de la noche, tan sencillo y pulcro, pero cargado de un simbolismo hermoso, heredado de sus lecturas de los poetas de Black Mountain, Virginia, sobre todo de Denise Levertov, una escritora a quien guardó devoción hasta la muerte.

José Manuel había estado en los Estados Unidos, haciendo un postgrado en Lógica Simbólica en la Universidad de West Virginia y allí se interesó por este grupo de escritores nuevos, que estaban muy interesados en una estética muy diferente a la que primaba en aquel entonces en EE.UU. Eran principios de los años setenta, una época muy contestataria, donde la poesía Beatnicks y el Hipismo llevaban la vocería. Esta poesía, a diferencia de aquélla, estaba muy volcada a lo público, eran famosos los grandes recitales que se hacían en los campus universitarios, eran los años de la guerra en Vietnam y lo vanguardista, surreal y contestatario estaba al día. 
Los poetas de The Black Mountain atendían a otra estética: poesía recogida, íntima, muy vinculada a cierto simbolismo, que José Manuel aprovechó y asimiló muy bien en este su primer libro.

Este lugar de la noche es un libro simbolista. En él ya se establecen de una vez por todas las formas características de su poesía: el poema corto y sugestivo, lleno de revelación. Entonces, digamos, que ese año que J. M. pasó en Estados Unidos, estudiando en West Virginia, fue muy rico, pues se decidió no solo a escribir poesía (antes había escrito algunos cuentos que él me envió e, incluso, con alguno de ellos concursó en Cúcuta, quedando de finalista), sino también, a su regreso, a publicarla.

LHVT: Hay algo que me llama la atención. Usted estuvo ahí no solo “metiéndolo en la grande", como él dijo, sino también ayudándole en la publicación de los libros. No sé en el caso de Signos, pero usted debió ayudarle con Cantiga...

ER: Sí. Yo lo publiqué en la editorial de la Universidad de Antioquia, en la Colección Celeste. Bueno. Es que se desarrolló una amistad muy grande entre los dos. Entre las dos familias. Él estaba recién casado; tenía sus hijos pequeños. Yo también estaba recién casado; tenía los hijos pequeños. Luego nos fuimos congregando con otros amigos, como Manuel Mejía Vallejo, Fernando González Restrepo, Miguel Escobar, Óscar Jaramillo, Juan José Hoyos, Víctor Gaviria, Helí Ramírez, Jesús Gaviria, Orlando Mora, Darío Ruiz... En fin...También, con algunos de ellos, nos agrupamos para sacar la revista Acuarimántima, en el año 73, una revista que, pese a su inmensa y absoluta modestia, ha tenido un gran efecto, no sólo en el medio local; la gente todavía la recuerda y pregunta por ella, pregunta si sigue saliendo, a pesar de que dejó de salir desde el año 83. 
Acuarimántima se publicó durante diez años. Con ella conseguimos algo que nos propusimos desde un comienzo: que la revista fuera un espacio no sólo para los nuevos escritores, entre los que recuerdo a Helí Ramírez, Víctor Gaviria, Héctor Abad Faciolince, Juan Diego Mejía, Santiago Mutis, Anabel Torres, Jaime Alberto Vélez..., sino también un espacio para autores en otros idiomas, contemporáneos y del pasado. José Manuel tradujo a Georg Trakl y a Ossip Mandesltan de algunas versiones del inglés, y a Philiph Levine, Kenneth Patchen y Thomas Merton; igualmente, Amilkar Osorio tradujo a Ezra Pound y Wallace Stevens y hay traducciones de la poesía de Pasolini, René Char, Drumond de Andrade, en fin, de los poetas que más nos interesaban.

Para el ambiente que se vivía en aquel entonces, de ebullición y de mucha inquietud intelectual (Recuerda que eran los años 70), Acuarimántima cumplió lo que se propuso.

Como, además, despertaba el interés de un grupo amplio, la gente nos ayudaba con el patrocinio a realizarla. Nos daban dinero para pagar los costos de edición. Fue un trabajo muy bonito, muy comunitario, de un gran entendimiento y entrega entre los que la hacíamos. Vinculamos también a ella, por ejemplo, a los pintores, a la nueva generación de pintores antioqueños, que se empezó a formar después de las bienales. La portada siempre la hacía alguno de ellos.

Fue, pues, una revista que se fue haciendo paralelamente a nuestro trabajo de escritores y que nos permitió conocer a otras personas y vincular su trabajo al nuestro. 
LHVT: Usted publica Cantiga. Después, en el 88, la edición del Premio Nacional de Poesía por reconocimiento...

ER: No, yo ya no estaba en la colección. Cantiga, sí, por supuesto. Un nombre sacado de Las Cantigas a la Virgen María de Alfonso El Sabio.

LHVT: Y después sacó la obra Poesía completa.

ER: ¡Ah! Sí. Pero ya J.M. había muerto. Quisimos conmemorar el primer año de su muerte, con la edición completa de sus poemas. Por supuesto, con la colaboración de la Universidad, que quería hacerle también un homenaje. Y con la colaboración de Clara, su mujer, y sus hijos, que nos facilitaron el material, reunimos todos los textos, y también los poemas póstumos. Hicimos esa edición con la idea de que el lector, el investigador, el estudioso, tuviera a mano toda la obra escrita. Quisimos que la publicación fuera cuidadosa y respetuosa.

José Manuel es un autor muy particular: examinando este libro da la impresión de que él sabía desde un principio los términos, procesos y formas de su obra. Como si la hubiera "visto" de antemano, nunca extravió el camino.

LHVT: El número 48, como número de poemas, aparece en algunos de sus libros...

ER: ¿Sí? Pues, bueno, no sé. La verdad, lo ignoraba. Supongo que tenga que ver, en caso de que sea así, con su formación filosófica y matemática. Por lo general, la obra de un autor está sometida a cambios y azares; son muchas las circunstancias que concurren en su realización como para que el autor tenga un gobierno absoluto sobre lo que escribe, más si se trata de la poesía, donde el ejercicio intelectual no garantiza nada, ni es suficiente. Sin embargo, en su escritura, uno tiene la impresión contraria. 
Parece que él tuviera agarrado a su demonio desde un principio, haciéndole decir lo que él quería.

LHVT: Parece que su obra estuviera prefijada de antemano...

ER: Si, te lo repito, como si supiera de antemano cuál era su música y hacia dónde ir. De ahí ese cuidado por la forma, su intensa espiritualidad, su rigor. Escribió, digamos que con clarividencia.

LHVT: En la edición de la obra poética completa, ustedes introdujeron dos poemas que aparecieron en la revista Imago...

ER: ...y que él no había incorporado a la sección "Otros poemas" de su obra. Alguna vez le pregunté por qué los había dejado por fuera de sus libros. Él tenía algunas dudas al respecto y lo consultó con alguien que no le recomendó publicarlos. Pero son poemas muy bellos. Y en nada desmerecen dentro del conjunto.

En la edición de su Poesía Completa aparecen los poemas póstumos tal como él los dejó organizados. Se advierte que los había revisado una y otra vez. Estoy seguro de que tenía en mente publicarlos pronto. Reafirman y amplían la experiencia poética de los libros anteriores. Aún no poseían un título, algo que nos pareció natural respetar.

LHVT: Aparte de Acuarimántima, que es una palabra inventada por Barba Jacob...

ER: Sí. Sí. por supuesto...

LHVT: Ustedes fundaron DesHora....

ER: Sí. Varias revistas... Mira: lo de Acuarimántima fue muy claro. En aquella época de vanguardia de los años 70, quisimos que nuestro trabajo editorial con la revista tuviera un derrotero muy claro respecto a nuestras raíces y nuestra tradición 
poética. Entonces, ¿qué mejor emblema, digámoslo así, que este nombre de un poema famoso de Barba Jacob?

Sabíamos que en un medio tan precario como el del Medellín de entonces, era necesario hacer algo; y lo más a mano era hacer revistas culturales, revistas de poesía, que dieran una dimensión del trabajo poético a nivel nacional e internacional. Acuarimántima duró diez años, del 73 al 83, y publicamos 37 números. Luego, intentamos de nuevo con otra revista que se llamó Poesía ${ }^{187}$. De ésta publicamos once números, duró cinco años. José Manuel no estuvo al comienzo, pero luego le pedí que se vinculara, pues él fue siempre una persona cuyo espíritu generoso, nada egoísta ni egocéntrico, facilitaba mucho este tipo de trabajo... y por amor a la poesía, por supuesto. Se unió después del tercer número, con traducciones de algunos poetas canadienses.

A finales de los años 90, surgió la idea de hacer DesHora. En un comienzo, José Manuel estaba escéptico. Pero después aceptó e invitamos a los escritores y periodistas Juan José Hoyos y Maryluz Vallejo, y al negociante Guillermo Baena, y juntos iniciamos la aventura de DesHora, que duró hasta la muerte de José Manuel.

LHVT: Después de que murió José Manuel, usted que no quiso seguir con ella...

ER: Sí. Es que ya no tenía sentido... Ya no quedaba con quien hablar de estas cosas.

LHVT: ¿Por qué DesHora? Arriesgo: César Vallejo. Es muy notable además que, cuando uno ve el logotipo de la revista, la h es mayúscula...

187 Además de Elkin Restrepo y Arango, Poesía fue hecha por Fernando Macías y Adelaida Correa [Nota de Elkin Restrepo]. 
ER: Sí. Es una pequeña disonancia que visualmente funciona, un pequeño truco para darle singularidad, carácter a la publicación, para que el lector lo recordara, y que el pintor Óscar Jaramillo nos sugirió.

¿Por qué DesHora? Mira: El comité hizo una lista de posibles nombres, cuando nos sentamos a pensar la revista y a ver cómo la realizábamos. De entrada no surgió ninguno que tuviera la aceptación de todos. Había varios, tentativos, algunos muy buenos, pero ninguno que nos gustara suficientemente. Por aquellos días, en el apartamento de José Manuel, nos reunimos varios amigos, que no eran del Comité, a pasar un rato, quizá a ver un partido de fútbol, no sé..., a tomarnos unas copas. En la conversación salió la preocupación de qué nombre ponerle a la revista. Revisamos de nuevo la lista que habíamos hecho. Y nos gustó DesHora. No porque pensáramos en alguna vinculación con Vallejo. Es decir, la palabra, de momento, no tenía mayor sentido. Pero lo interesante es que la revista, con el paso del tiempo, se lo dio y terminó casi definiendo a la poesía misma, pues ella siempre está a deshora respecto a su tiempo, y esto es lo interesante.

LHVT: Me puse a darle vueltas al nombre, y encontré un poema de Vallejo donde dice: "Y tú, sueño, dame tu diamante implacable,/ tu tiempo de DesHora"...

ER: Nos encanta si el nombre establece ese tipo de relaciones. Creo que fue un buen nombre. Y, a diferencia de las anteriores aventuras editoriales nuestras, esta era mucho más amplia y ambiciosa. El primer número tuvo más de 120 páginas, en muy buen papel, un bond de noventa gramos, extranjero, con un formato que recordaba al de la revista Poetry, en la versión mexicana. Nos gustó ese formato por más clásico y propio para la poesía. El primer número fue muy bien comentado en Cromos, por Marianne Ponsford, quien elogió, entre otros aspectos, los derroteros que la revista 
tuvo claros desde un principio. Por ejemplo, aprovechando la presencia de Juan José Hoyos y Maryluz Vallejo, magníficos periodistas, creamos por fuera de la parte principal dedicada por entero a la poesía, una segunda, que midiera el pulso de la realidad nacional y del mundo, con artículos, comentarios y reseñas. La llamamos "VARIA LECCIÓN"... También se publicaron cuentos, completándose con un perfil del autor, hecho por Juan José o por el mismo autor, como en el caso de Juan Diego Mejía.

A mí la revista me satisfacía profundamente (y creo que a todos) porque era una revista muy seria, editorialmente con muchas más virtudes que las anteriores. Ahora: el ambiente ya había cambiado; ya no había ese espíritu de los años 70 que era tan amplio, que lo recorría todo y que facilitaba una comunicación con un público interesado. De nuevo tocó empezar a establecer relaciones, a crear un público de la revista, cosa difícil, pero que por supuesto se fue dando. La revista sacó nueve números. El último salió días después de que murió José Manuel.

LHVT: ¿Cómo le parecen a usted los ensayos de José Manuel?

ER: J. M. no es escribió mucha prosa, pero cuando lo hizo en artículos, reseñas, ensayos (en algunos cuentos, como te dije antes), estos tenían los mismos atributos de su poesía: eran escritos muy meditados, breves, con una economía verbal muy grande, comprometiéndose muy vivamente con el tema o asunto respectivo. J.M. no era pródigo en adjetivos, sí muy exacto, aunque a veces, mirando alguno que otro prólogo hecho a petición de sus autores, sobre todo tratándose de jóvenes, "Jóse" perdía la razón y se volvía gloriosamente irresponsable; algo que habla mucho de su generosidad, que lo llevaba a traicionar, digamos, su filosofía. 
LHVT: Dice David Jiménez sobre el ensayo que José Manuel hizo para la edición de sus traducciones de los poemas de William Carlos Williams: "el ensayo breve y espléndido"...

ER: Estoy de acuerdo...

LHVT: Me parece que se debería pensar en editar los ensayos de José Manuel, en hacer un libro con sus ensayos.

ER: ¿Si alcanzaría para un libro?

LHVT: Son textos muy cortos...

ER: Muy cortos, y no sé si darían para un libro. Habría que mirar. Me parece una idea estupenda.

LHVT: La Universidad de Antioquia publicó Signos en 1978, Cantiga en 1987, Poemas escogidos (edición del Premio Nacional de Poesía por reconocimiento) en 1988 y en 2003 la Poesía completa...

ER: ...y en el 2006 salen las traducciones de Emily Dickinson, segunda edición.

LHVT: ¿'Tiene novedades?

ER: No. Yo le había pedido a José Manuel, para la Colección Poesía de la Editorial Universidad de Antioquia, el libro para una nueva edición. Él me dijo que iba a hacer una revisión del libro, que le diera tiempo, y en ese lapso quiso consultarle sus versiones a Anabel Torres. Anabel conoce muy bien el inglés; es su idioma natal, digamos. La última vez que hablamos, una semana antes de la muerte, me dijo: "El libro se demora", pues estaba en ese proceso de consulta con Anabel. 
Muere José Manuel, y empezamos a revisar, junto con las propuestas hechas por Anabel, la versión de archivo. Por lo que advertimos, aún no había integrado ninguna de las sugerencias de ella a su versión. Lo que nos creó una dificultad muy grande. ¿Cómo integrar en la edición lo que el propio J.M. no había hecho por una u otra razón? Con esto no queremos desconocer la voluntad de J.M. de que estas versiones fueran conjuntas, pero en el archivo no aparecen y no sería ético hacer lo que él no hizo, sin saber incluso exactamente cuáles serían esos cambios. Además porque, comparando una y otra versión, las diferencias en tonos y sentidos es tan grande (también hay coincidencias muy felices), que podría hablarse de dos traducciones muy diferentes. Por eso -ya se convino con Clara y los hijos-en el 2006 se publicará la edición de los poemas de E. Dickinson, tal como J. M. la publicó, con algunos otros poemas que tradujo cuando se planteó la posibilidad de esta edición.

LHVT: Ya hemos hablado un poco de usted como el hombre que se ocupó de seguir la obra poética de Arango y publicarlo en muchas ocasiones, de su relación con él en la fundación de revistas. Hemos hablado de lo que tiene que ver con los ensayos de él, y que podría ser interesante pensar en la posibilidad de publicarlos...

ER: De verdad que sí... Vamos a pensarlo. Sería muy bueno. Habrá que hablar con Clara y con los hijos, de lo que piensan al respecto. De todas maneras, si son textos conocidos, no creo que haya problema, porque si él los publicó, de hecho estaba conforme con ellos.

LHVT: Sería bueno tenerlos recogidos, porque de otro modo la consulta es muy complicada. Yo conozco el ensayo sobre William Carlos Williams, las notas de él sobre este último y los otros dos poetas cuyas traducciones aparecen en Tres poetas norteamericanos: Whitman, Williams, Dickinson. Conozco igualmente el prólogo a 
Han-shan. He trabajado mucho el ensayo sobre Aurelio Arturo, y cada vez me gusta más. No conozco los textos sobre Mutis, Jaramillo Escobar ni el texto sobre su poesía.

ER: El de Jaramillo Escobar lo publicó la revista Poesía. Es una paginita. Una página muy buena..., digámoslo así.

LHVT: Es una pregunta difícil, porque se mezcla el afecto, porque ustedes fueron compañeros de andar, de "baile", como él decía: ¿qué lugar le daría a él en la poesía colombiana?

ER: Por supuesto, un lugar primordial. Pero mira que la obra de un autor, su importancia y conocimiento es también obra de las distintas generaciones que la leen y, a su vez, llegado el caso, la enriquecen y transforman. Yo espero -y todo lo indica así- que la obra de él irá ganando cada vez más reconocimiento, se irá ubicando cada vez mejor en el panorama general de la poesía colombiana e inclusive -como decías tú ahora- latinoamericana.

LHVT: En la entrevista que le hizo Piedad Bonnett a Arango, le pregunta ella a cuáles de los poetas colombianos ha tenido cerca, en su trabajo. Responde que primero que todo está Silva: "A mí Silva no me cansa. Siempre encuentro un matiz nuevo". Y agrega que "Silva es como el padre muerto joven de todos nosotros. En él están la pregunta por el progreso y la pregunta por la posibilidad de la poesía”. Pregunta por el progreso. Pregunta por la posibilidad de la poesía. Para aclarar la segunda, indica que en Silva está esa línea donde dice que el verso es vaso santo y al mismo tiempo escribe una anti-poesía más fuerte que la del “Tuerto” López. 
ER: Eso es muy interesante. A mí me gusta más este último aspecto que el otro, el simbolista... Pero no sé. He leído a Silva, pero no con... la pasión nacional. No sé por qué, aunque está conmigo desde niño: desde muy muchacho leí a Silva. Me impactaba ese aspecto sugestivo, simbolista, de penumbra, muy francés y también muy nuestro en otros aspectos... Pero yo no llevaría a Silva a una isla desierta. No creo.

LHVT: José Manuel parece decir que Silva es el fundador de la poesía moderna en Colombia...

ER: Eso sí. Indudablemente. Ya lo otro es el gusto personal. Uno de todas maneras tiene su "santoral", y aunque no dejo de reconocer la importancia de Silva como poeta y la importancia de su papel en la poesía colombiana, mi devoción por él es muy variable...

LHVT: A usted le gusta mucho De Greiff...

ER: En De Greiff hay algo que creo dificulta su lectura, lo que la gente reitera: que usa un lenguaje abstruso, con neologismos, anacronismos y palabras inventadas. Pero se olvida que todo esto hace parte, junto con la música y su visión acerca de la naturaleza y la aventura poética, de un proyecto intelectual muy amplio y complejo, algo que ningún otro poeta en nuestro idioma se ha atrevido a realizar. De Greiff está fuera de toda época y reúne en su poesía el legado de varias tradiciones. Él es un autor, como se dice ahora, de culto, dada su extrema singularidad. A mí siempre me ha parecido que es una especie de catedral medieval. 
LHVT: Si tuviera que definir brevemente a ese José Manuel que para usted está en cifra en su primer libro (Este lugar de la noche), ¿cuáles serían los rasgos más notables del poeta?

ER: Ya los conocemos, las entrevistas que se le hicieron lo muestran tal como es. Quizás agregaría que si a José Manuel se le hubieran quitado los zapatos en algún momento, hubiera asomado la pezuña del sátiro, del cabro dionisiaco. Ese era su verdadero ser.

Además daba la impresión, no muy común entre los escritores, de sabiduría; una sabiduría que, aunque también se nutría de la lectura y los libros, no perdía su contacto con el mundo. La suya era una sabiduría de viejo maestro de escuela. En los últimos años, tenía como paradigma a don Antonio Machado. Alguna vez se le dio la oportunidad de viajar a Madrid, y él aceptó la invitación porque pensó que entonces podría visitar Soria. En Soria, cosa curiosa, hay muy poco que recuerde a don Antonio Machado. Ahora que estuve en España, quise hacer el viaje que él soñaba realizar y que por un cambio a última hora de funcionarios en la Embajada, no pudo cumplir. Pero buscando información en internet, descubrí que en Soria hay muy poco, prácticamente nada, que recuerde a Machado y los años que vivió allí, salvo una placa con algún soneto suyo colocada en una vieja encina. En Soria, el poeta conoció a su mujer; allí vivió con ella y fue profesor.

Al final de la vida de J.M., en torno suyo, se fue formando un grupo de amigos, gente de diversa idiosincrasia, que le manifestaban una gran devoción y que actuaban casi como sus discípulos...

LHVT: Como Gustavo... 
ER: "El Hamaquero". Sí, él quería mucho a "El Hamaquero". Lo sentía muy cercano, siendo tan distintos. De los cercanos siempre habló de él con un gran afecto y reconocimiento.

LHVT: Creo que a mí me alcanzó a decir algo así como: “El Hamaquero’ durante mucho tiempo fue mi 'director espiritual', pero ahora ya no".

ER: Entre los poetas, José Manuel también admiraba a Epifanio. Epifanio está muy vinculado a la tierra, a las montañas, a la selva, y es el primero que habla poéticamente de lo nuestro, de Antioquia. De una manera inocente, ingenua, si se quiere; pero él es el patriarca. Y para José Manuel creo que era muy importante, en los últimos años, reconocerse dentro de esa tradición de la poesía antioqueña que arranca desde allí, desde "el loco" Epifanio.

LHVT: Dos palabras: "lo nuestro", "lo antioqueño" en Montañas.

ER: Es muy propio de la tradición poética antioqueña: esa afirmación de lo propio, de lo lugareño. Es una tradición que está muy enraizada tanto en la poesía y la literatura, como en el arte. Elige el poeta que quieras y encontrarás una poesía enraizada. Quizás la devoción de José Manuel por Asunción Silva nazca de una complementariedad: Silva es el $d a n d y$, el sibarita, el parisino y cosmopolita, todo lo contrario de lo que él era. En Antioquia, si se quiere abreviar, el sino de sus artistas lo establece la fijación y la errancia; entre esos dos términos se mueve el péndulo de su entidad espiritual. Al lado de Epifanio y Gregorio Gutiérrez que nunca se movieron de su casa, están Barba y don Baldomero Sanín Cano que fueron andariegos, y así...

LHVT: José Manuel dice en la entrevista a Babel que nunca ha dejado de ser un campesino. 
ER: Cada vez se afirmaba más en esto. De hecho vivió muchos años en Copacabana. Una vida campestre. Mira esta frase de Eliot que es tan exacta, de los Cuatro cuartetos, de que el fin de toda búsqueda te regresa al comienzo. José Manuel era muy claro en esto.

LHVT: Es interesante ver esa actitud campesina, de vuelta a lo nuestro, en relación con la insistencia de Arango en los presocráticos: también vuelta al comienzo, a los orígenes.

ER: De ahí esa impresión tan fuerte que producen sus poemas.

LHVT: Pero en Carmen de Viboral nació y vivió su infancia.

ER: Después regresó ya de adulto, con su mujer y sus hijos, mucho antes de vender su casa en Medellín para irse a vivir a Copacabana.

Este hecho marcó su poesía de una manera muy grande. Ésta abandonó en mucho su simbolismo de un comienzo, para hacerse más desnuda, más "ñuda", como él diría.

LHVT: El cambio puede estar en Cantiga....

ER: Mira la palabra tan bella que él utiliza para darle nombre al libro. Él la tomó por supuesto de las Cantigas del rey Alfonso, "El sabio". Él siempre iba hacia atrás, reconociéndose en una tradición más amplia, la de nuestro propio idioma. En los últimos años hablaba mucho de Quevedo, lo conocía de memoria.

LHVT: Siendo muy grande el ensayo de David Jiménez sobre Arango, parece que falta señalar en él referencias muy importantes para la poesía de José Manuel. Hay que hablar de Machado, de Quevedo, hay que hablar de Unamuno, de Lezama... 
ER: Y es raro porque Lezama es un barroco, y él era todo lo contrario, muy escueto, muy desnudo en la expresión... Hay que hablar también de Fernando González.

Mira: hay algo que puede ser interesante. Alguna vez vi una película rusa, que se llamaba El fallo. En el momento de la perestroika. Recuerdo que la historia es la de un poeta oficial, consagrado por el poder, que viaja a un pueblo remoto de Rusia y allí encuentra a una estudiante, que le habla del poeta del lugar, un hombre desconocido, ignorado, del cual no se tiene noticia. Y el poeta oficial se interesa en él; le despierta mucha curiosidad este personaje del cual le habla la muchacha. Y su indagación de pronto le revela hasta dónde su vida (para no hablar de su poesía) ha sido falsa y hasta donde su destino de poeta es una comodidad gubernamental, hija del poder.

Este es el tema de la película.

Alguna vez se la comenté, y vi la impresión que le produjo. “QQué bueno verla! ¡Qué interesante! Si la vuelven a presentar, "llamáme".

Yo creo que a J.M. no le importaba el reconocimiento -que lo tuvo, y que por supuesto nunca buscó-. A él nunca le interesó tener éxito, triunfar, ser alguien, estaba por encima de eso. Quería cumplir lo suyo y su paradigma era Machado, el poeta de provincia, que no le hace el juego ni al poder ni a nada. En esto era ejemplar.

LHVT: Si hay algo que pasó con Heiddeger o Nietzsche es que ellos fueron los que operaron de una manera muy fuerte la vuelta a los presocráticos, la vuelta al origen... 
ER: Acuérdate de un discípulo de Heidegger, Abel Posse. Él ofrece un testimonio (publicado en la revista Eco) de los años finales del filósofo.

Heidegger, como se sabe, regresa a su pueblo natal, en la Selva Negra. Sus amigos y contertulios eran los campesinos, a los cuales les leía las páginas que había escrito sobre Hölderlin, los poemas mismos y anotaba sus comentarios.

Si el final de la búsqueda es volver al origen, es normal que en un hombre de conocimiento las cosas sucedan de esta forma. Y como la vida, en caso de que la aceptes como debe ser, te lleva a la simplificación (para no engañarte), a estar desnudo, como decía Fernando González, entonces qué más propio que esa vuelta a casa, que ese establecer diálogo con lo que es propio y verdadero...

LHVT: Recuerdo los versos del poema "Regreso", de Montañas, que dicen: "Volver a la casa/ como quien regresa/ ya viejo a una mujer". -Estoy falseando a José Manuel-. Ahí mismo están los versos: 'Y de nuevo acostarse en la cama del padre/ y el oscuro temor de calzar en la horma de su muerte"... Un poema dedicado a Gloria, que debe ser una hermana.

ER: Sí es una hermana. Una mujer muy inteligente... Es que en el conocimiento, como en todo, hay trampas... y distractores... y falsos caminos. Y yo creo que lo más significativo es no perderse, extraviarse. La poesía siempre será una buena guía. Y yo creo que José Manuel sabía muy bien esto. Y esa es la lección; aunque él nunca pretendió dar lección a nadie. Me contaba Gloria, del momento anterior a la muerte, cuando lo llevaron de infarto a la clínica, que todo el mundo estaba preocupado, y él volteó y le dijo: "Yo tengo las maletas listas, tranquila".

Enfrentó la muerte como enfrentó la vida: con valor y serenidad. 
LHVT: Es muy raro el caso de José Manuel. Saca un libro en el 73, y de inmediato la estrellita de José Manuel Arango empieza a brillar bien fuerte en el firmamento.

ER: No. La poesía de él tuvo un tiempo en que apenas fue leída o advertida por unos cuantos. Su momento llegó gracias a la publicación de Colcultura, edición de la cual se encargó Santiago Mutis.

LHVT: Hay cuatro poetas grandes nacidos en los años 30: Mario Rivero, Jaime Jaramillo Escobar, José Manuel y Giovanni Quessep. ¿Usted qué piensa de Quessep?

ER: Una poesía muy diferente a todas, muy del mundo de la fábula. Siempre perfecta. Es el tipo de poeta que escribe siempre alrededor de un núcleo esencial. Cada nuevo poema no es más que una variación de un texto, de una escritura original, digámoslo así, que le sirve de motivo.

LHVT: ¿Cuál le gusta más?

ER: Por cercanía, Jaramillo (Porque es el que más ha arriesgado) y José Manuel. También Giovanni, pero es otro tipo de poeta. Me gusta un libro como Canto del extranjero: es un libro muy bueno aquí y en cualquier parte. A diferencia de él, el mundo de José Manuel y el de Jaime no son de fábula sino muy cercanos y muy concretos, muy nuestros, y rompen con todos los moldes. Igualmente, Mario.

LHVT: Fue muy importante en su momento.

ER: En su momento, sí. En los años sesenta. Le dio un tono coloquial a una poesía que era muy seria, muy estirada, muy... boba. Creó un tono coloquial que venía de la poesía americana, por supuesto. Y eso fue importante. 
LHVT: Le pregunté por Quessep, porque, como dijo Darío Jaramillo Agudelo, Mario Rivero y Jaramillo Escobar son poetas autodidactas; José Manuel y Giovanni, profesores universitarios, con postgrados además...

ER: ...y con estudios en el extranjero... Giovanni es como un episodio olvidado de las Mily una noches. Él está ahí. Y en el Dante...

LHVT: A mí me parece a veces la obra de Quessep una variación alrededor del libro sexto de la Odisea, el encuentro entre Odiseo y Nausicaa...

ER: ¿Verdad? Yo lo veo más por el lado de las Mily una noches. Por supuesto que su reflexión es: la vida es fábula. Su primer libro es El ser no es una fábula, pero leyendo su obra en conjunto, la afirmación es la contraria: el ser es una fábula.

Se acaba de publicar su último libro en la editorial de la Universidad. Se llama Brasa lunar.

LHVT: ¿Qué piensa usted de Raúl Gómez Jattin?

ER: Excelente. Me encanta. La vida que él llevó fue una vida difícil. Esa idea de poeta maldito (que él mismo desconocía) es una pendejada. Es creer que la figura del poeta tiene que ser la que creó Francia en el siglo XIX. Mira que cuando José Manuel eligió a Machado irrespetó esos moldes. Y Gómez Jattin tiene la misma lucidez: "Yo no soy poeta maldito ni nada de esas cosas", aunque llevó una vida terrible; que no se le desea a nadie. Pero su poesía es muy bella. Fuerte, vital. También muy afincada en su lugar, también buscando sus orígenes. Y con un desparpajo maravilloso...

LHVT: A mí me da la impresión, cuando lo leo, que hay una fuerza vital que barre con todo... 
ER: Primigenia... Una fuerza vital, una fuerza de la naturaleza que establece su cauce, crea su forma.

LHVT: Muchas gracias, Elkin. Usted ha sido muy generoso.

Medellín, 17 de noviembre de 2004 


\section{Bibliografía}

\section{Obras de José Manuel Arango}

\section{Poesía}

Poemas escogidos, "Premio Nacional de Poesía", Universidad de Antioquia, Medellín, 1988.

poemas reunidos, Norma, Bogotá, 1997.

La sombra de la mano en el muro. Antología, Palimpsesto, Sevilla, España, 2002.

La tierra de nadie del sueño. Poemas póstumos, Ediciones DesHora Intergraf, Medellín, 2002.

Poesía completa, Editorial Universidad de Antioquia, Medellín, 2003.

Este lugar de la noche, Prólogo de Mario Jursich, Colección de poesía, Universidad Nacional de Colombia, Bogotá, 2006.

\section{Antologías}

Obra en marcha1. La nueva literatura colombiana (Varios autores), Colcultura, Bogotá, 1975.

Una generación desencantada (Varios autores), Universidad Nacional, 1985.

\section{Traducciones}

Whitman, Dickinson, Williams. Tres poetas norteamericanos, Norma, Bogotá, 1991.

El solitario de la montaña fría. Poemas de Han-Shan, Intergraf editores, Medellín, 1994.

En mi flor me he escondido. Poemas de Emily Dickinson, Versiones de José Manuel Arango, Intergraf editores, Medellín, Colombia, 1994.

\section{Ensayos}

"La lógica nueva, una crítica de la razón", en: Actas del III Foro nacional de filosofía, revista Ideas y Valores, Nos. 53, 54, Universidad Nacional de Colombia, Bogotá, 1978, págs. 81 a 86).

“Aurelio Arturo y la poesía esencial", En: Aurelio Arturo. Morada al sur y otros poemas, Norma, Bogotá, 1992.

"Una poesía para nuestro tiempo", En: El transeúnte paso a paso, Selección y prólogo de Juan Gustavo Cobo Borda, Colección "Premio Nacional de Poesía por reconocimiento", Universidad de Antioquia, Medellín, 1999. 
"La poesía de William Carlos Williams", en: Whitman, Dickinson, Williams. Tres poetas norteamericanos, Norma, Bogotá, 1991.

\section{Trabajos sobre José Manuel Arango}

\section{Ensayos}

Hoyos, Juan José, "Un recuerdo de José Manuel Arango", En: El Malpensante, Bogotá, No 38, Mayo 1 -junio 15 del 2002 (El texto parece una versión corregida y ampliada del texto “ 'No hay camino, dijo el maestro", aparecido en Babel No 4, Medellín, Diciembre de 1996Marzo de 1997).

Cruz, Francisco José, “Acercamientos a José Manuel Arango”, En: José Manuel Arango, La tierra de nadie del sueño. Poemas póstumos, Ediciones DesHora Intergraf, Medellín, 2002.

Jiménez, David, "la poesía de José Manuel Arango", En: José Manuel Arango, La tierra de nadie del sueño. Poemas póstumos, Ediciones DesHora Intergraf, Medellín, 2002 (Este ensayo fue publicado antes en: Boletín cultural y bibliográfico, Banco de la República, Número 47, Volumen XXXV, 1998, págs. 43 a 75).

Jursich, Mario, "Prólogo. Las deidades perdidas", en: Este lugar de la noche, Colección de poesía, Universidad Nacional de Colombia, Bogotá, 2006.

Ospina William, "La radical extrañeza de todo. José Manuel Arango", en: Por los países de Colombia, Eafit, Medellín, 2002. (El texto también fue publicado por la revista Número \#33, de junio a agosto de 2002, y aparece en José Manuel Arango, La tierra de nadie del sueño. Poemas póstumos, Ediciones DesHora Intergraf, Medellín, 2002.)

Vargas Torres, Luis Hernando, "La percepción en la poesía de José Manuel Arango", (Inédito), Bogotá, 1991.

"Cosas a un tiempo familiares y ajenas. La aventura de la palabra en José Manuel Arango”, (Inédito), Bogotá, 2001.

José Manuel Arango. Poética y poesía (Inédito, 2006)

"Las reflexiones de José Manuel Arango sobre la poesía" (Boletin cultural y bibliográfico, Vol. XLIII, N 73, 2006 -publicado en 2008-, Banco de la República, Bogotá, 2008, págs.17-52)

\section{Entrevistas}

Bustamante, Víctor, y otros, "Conversatorio con José Manuel Arango. El excesivo pudor", Babel, N 4, Medellín, Diciembre de 1996 - Marzo de 1997.

Bonnett, Piedad, "Entrevista con José Manuel Arango", En: José Manuel Arango, La tierra de nadie del sueño. Poemas póstumos, Ediciones DesHora Intergraf, Medellín, 2002.

Rodríguez Núñez, Víctor, "La poesía es eficaz, nos cambia", Magazińn dominical, "El Espectador", N 632, 25 de junio de 1995. 
Vargas Torres, Luis Hernando, "Conversación con José Manuel Arango”, 2001. "José Manuel Arango. Conversación con Elkin Restrepo", 2004.

\section{Reseñas}

Jaramillo Agudelo, Darío, "Descripción precisa, escueta, penetrante", Boletín Cultural y bibliográfico, Banco de la República, Bogotá, 1995.

O’ Hara, Édgar, "La ciudad del trovador", Boletín Cultural y bibliográfico, Banco de la República, Volumen XXV, Número 15, 1988.

Cote Baraibar, Ramón, “Todas las cosas están llenas de dioses, decía Heráclito”, en: Boletín cultural y bibliográfico, Vol. XXVI, N 21, 1989. (Tomado de internet).

\section{Bibliografía general ${ }^{188}$}

Arbeláez, Jotamario (Compilador antología), Doce poetas nadaístas de los últimos días, Centro Colombo-Americano, Bogotá, 1986.

Arciniegas, Germán, Antología de León de Greiff, Biblioteca Colombiana de Cultura, Instituto Colombiano de Cultura, Bogotá, 1976.

Ardila de Gutiérrez, Emma Lucía, "Poética de la obra de José Manuel Arango", en: Revista Estudios de filosofía, $\mathrm{N}^{\circ}$ 33, Universidad de Antioquia, Medellín, febrero de 2006, págs. 143 a 159. La autora señala que su "artículo parte del trabajo de investigación Poética de la obra de José Manuel Arango, para optar al título de Magíster en Filosofía" de la Universidad de Antioquia.

188 Aun cuando por diversas razones no coloco en la bibliografía discos que me han acompañado no solo durante la elaboración de este trabajo sino durante buena parte de la vida, es pertinente señalar la importancia que para esta reflexión tiene lo que se podría llamar canción poética en lenguas española, catalana y francesa.

He seguido la obra de Joan Manuel Serrat desde 1972. Aunque es difícil señalar, entre sus trabajos, materiales que no sirvan a esta reflexión, al menos habría que destacar sus obras sobre Machado, Miguel Hernández y el uruguayo Mario Benedetti. Por otra parte, un trabajo como Mố, en el DVD que acompaña las canciones, tiene reflexiones sobre la composición de sus canciones que son útiles para pensar el trabajo poético. Me es más difícil señalar trabajos puntuales en el caso de Paco Ibañez, a través de quien he conocido muchos de los grandes poetas españoles.

He frecuentado mucho más tarde que a los anteriormente citados a Amancio Prada, pero trabajos como El cántico espiritual y Trovadores, misticos y románticos son muy importantes para quien esto escribe. Solo menciono el nombre de Lluis Llach de quien conozco pocos discos; pero un trabajo como Campanades a morts hace años me subyuga.

En el caso de los franceses solo señalo los nombres de Georges Brassens, Jacques Brel, Maxime Le Forestier, Georges Moustaki, Nana Mouskouri así como, aunque en menor medida, a Jean Ferrat, Léo Ferré, Charles Trenet. Igualmente a Reinhard Mey, algunas de cuyas obras conocí cantadas por él en francés.

Dejo para el final al argentino Atahualpa Yupanqui, quien, junto con los poetas, cantautores y cantantes mencionados ha alimentado mi reflexión. En su obra es fácil encontrar con frecuencia poéticas. 
Aristóteles, Poética, Monte Ávila Editores, Caracas, 1994.

La métaphysique, nouvelle édition entièrement refondue avec comentaire, par Jean Tricot, Paris, Jean Vrin, 1962.

$(1943)$.

Metafísica, traducción de Patricio de Azcárate, Espasa-Calpe, Madrid, 1981

Obras, Aguilar, traducción del griego, estudio preliminar, preámbulos y notas por Francisco de P. Samaranch, Madrid, 1973 (1964).

Arturo, Aurelio, "Palabra", "Lluvias", "Tambores", en: Golpe de dados. Revista de poesía, No 1, Vol. 1, Bogotá, enero-febrero de 1973.

................, Palabra, llwvias y tambores, Jaime Acosta Puertas, compilador, Ediciones Fondo Cultural Cafetero, Bogotá, 1999.

Obra e imagen, edición al cuidado de Santiago Mutis y Juan Gustavo Cobo Borda, Instituto Colombiano de Cultura, Bogotá, 1977.

Bogotá, 1992.

Bachelard, Gaston, "Instante Poético e Instante metafísico", en: La Intuición del Instante, Buenos Aires: Siglo XX editores, 1980.

Barba Jacob, Porfirio, Obras completas, Ediciones académicas, Medellín, 1972.

Basho, Matsuo y otros, Antología del haikú japonés. Poesía Zen, Gustavo Zuluaga Herrera, compilador, Editorial Endimyón, Medellín, 1990.

Bécquer, Gustavo Adolfo, Rimas y leyendas, Crisol N² 270, Madrid, 1965.

Baudelaire, Charles, Les fleurs du mal, Garnier-Flammarion, Paris, 1964.

..................... Las flores del mal, traducción de Nydia Lamarque, Losada, Buenos Aires, 1976 (1948).

1999.

, Salones y otros escritos sobre el arte, Trad. Carmen Santos, Visor, Madrid,

Béguin, Albert, El alma romántica y el sueño, F.C.E., 1954 (1939).

Blumenberg, Hans, "Situación lingüística y poética inmanente", en: Las realidades que vivimos, Paidós, Barcelona, 1999, págs. 143 a 158.

Borges, Jorge Luis, Obras completas 1923-1972, Emecé Editores, Buenos Aires, 1974.

La cifra, Alianza Editorial, Madrid, 1981.

Bréhier, Émile, Historia de la filosofía, Traducción por Demetrio Nañez, Editorial Sudamericana, Buenos Aires, 1942. 
Bonnett, Piedad, Imaginación y oficio. Conversación con seis poetas colombianos, Colección Celeste, Editorial Universidad de Antioquia, Medellín, abril de 2003.

Bundgård, Ana, Más allá de la filosofía. Sobre el pensamiento filosófico-místico de Maria Zambrano, Anthropos, Madrid, 2000.

Bozal, Valeriano, "Desinterés en la Crítica del juicio", en: AAVV, Estudios sobre la Crítica del juicio, La balsa de Medusa/Visor, Madrid, 1990, capítulo 2, págs. 75-87.

Berman, Marshall, Todo lo sólido se desvanece en el aire. La experiencia de la modernidad, Siglo Veintiuno Editores, 1991.

Cernuda, Luis, La realidad y el deseo (1924- 1956), Fondo de Cultura Económica, México, 1980.

Cobo Borda, Juan Gustavo, Antología de la poesía hispanoamericana, Fondo de Cultura Económica, México, 1985.

, Historia de la poesía colombiana. Siglo XX. De José Asunción Silva a Raúl Gómez Jattin, Villegas editores, Bogotá, 2003.

Presidencia de la República, Bogotá, 1997.

........................., "Una década de poesía: 1999-2008", Boletin Cultural y Bibliográfico, Banco de la República (www.coboborda.org).

Charry Lara, Fernando, Poesía y poetas colombianos, Procultura, Bogotá, 1985.

........................., José Asunción Silva. Vida y creación, Bogotá, Nueva Biblioteca Colombiana de Cultura, Procultura, Presidencia de la República, 1985, 528 págs.

Poesia y poetas colombianos, Procultura, Presidencia de la República, 1985.

Cote Lamus, Eduardo, Obra literaria, Biblioteca Básica Colombiana, Instituto Colombiano de Cultura, Bogotá, 1976.

Cruz Vélez, Danilo, El misterio del lenguaje, Planeta, Bogotá, 1995.

Descartes, René, Meditaciones metafisicicas con objeciones y respuestas, Trad. Vidal Peña, Ediciones Alfaguara, Madrid, 1977.

De Cervantes, Miguel, "Prólogo", en: Don Quijote de la Mancha, Edición, introducción y notas de Martin de Riquer, dos volúmenes, RBA Editores, Barcelona, 1994.

De Froidevaux, Gérald, "Modernisme et Modernité, Baudelaire face à son époque", en : Littérature, no 63, 1986.

De Greiff, León, Obra completa, dos tomos, Nueva Biblioteca Colombiana de Cultura, Procultura, Bogotá, 1985.

De Montaigne, Miguel, Ensayos (edición integral), tres volúmenes, traducción de Juan G. de Luaces, Ediciones Orbis, Barcelona, 1984 (1968). 
De Nerval, Gérard, Aurélia-Les Chimères-La Pandora, Édition établie et commentée par Béatrice Didier, introduction de Jean Giraudoux, Le livre de poche, Paris, 1972.

De Quevedo, Francisco, Antología poética, Edición, introducción y notas de José María Pozuelo, RBA Editores, Barcelona, 1994.

Echavarría, Rogelio, El transeínte, Fondo Cultural Cafetero, Bogotá, 1984. Antología de la poesía colombiana, selección y prólogo de Rogelio Echavarría, Ministerio de Cultura/ El Áncora Editores, Bogotá, 1997, 694 págs.

Eliot, T. S., Función de la critica y función de la poesía, Seix Barral, Barcelona, 1968. 1981. Cuatro cuartetos, traducción de J. R. Wilcock, Ediciones del 80, Buenos Aires,

Ferrater Mora, José, Diccionario de filosofía abreviado, texto preparado por Eduardo García Belsunce y Ezequiel de Olaso, Ediciones Drake, Medellín, 1995 (también versión en pdf).

Ferry, Luc, Homo aestheticus. L'invention du gồt à l'âge démocratique, Éditions Grasset \& Fasquelle, Paris, 1990.

Friedrich, Hugo, La estructura de la lírica moderna. De Baudelaire hasta nuestros días, Seix Barral, Barcelona, 1974 (1956).

Gadamer, Hans-Georg, Los caminos de Heidegger, trad. Ángela Ackermann, Herder, Barcelona, 2002, pág. 376. , La actualidad de lo bello, Ediciones Paidós, Barcelona, 1991. "Arte e imitación", en Estética y hermenéutica, Hans-Georg Gadamer, Editorial Tecnos, Madrid, 1998, pp. 81-93.

Graves, Robert, Los mitos griegos, dos tomos, Alianza Editorial, traducción de Luis Echávarri, Madrid, 1985.

$$
\text { La diosa blanca. Gramática bistórica del mito poético, Alianza Editorial, }
$$
Traducción de Luis Echávarri, Madrid, 1998 (1983).

Guthrie, W.K.C., Los filósofos griegos, Cap. IV, trad. de Florentino M. Torner, F.C.E., México, 2002 (1953).

Gombrich, Ernst, "Introducción: El arte y los artistas", en La historia del arte, contada por E. Gombrich, Editorial Debate, Madrid, 1998, pp. 15-37.

González, Ángel, El grupo poético de 1927 (Antología), Taurus, Madrid, 1979 (1976).

Guillén, Jorge, Obra poética. Antología, Alianza Editorial, Madrid, 1970. Al margen, Visor, Alberto Corazón, Editor, Madrid, 1972.

Gutiérrez Alemán, Carlos B., "Filosofía y poesía. Vecindad como cercanía y diferencia", en: Ideas y Valores. Revista colombiana de filosofía, Universidad Nacional de Colombia, Departamento de Filosofía, N 95, agosto de 1994, págs. 29 a 40. 
"La hermenéutica temprana de Heidegger", Ideas y Valores. Revista colombiana de filosofia, Universidad Nacional de Colombia, Departamento de Filosofía, $\mathrm{N}^{\circ} 107$, agosto de 1998, págs. 27 a 42.

Gutiérrez Girardot, Rafael, "La literatura colombiana en el siglo XX”, en: Manual de historia de Colombia, Colcultura, Bogotá, 1980, págs. 445 a 536.

Gutiérrez Girardot, Rafael, Modernismo, Barcelona, Montesinos, 1983.

Haar, Michel, Heidegger, Cahier de l’Herne, Paris, 1983 (Ce cahier a été dirigé par Michel Haar).

Habermas, Jürgen, "Modernidad versus postmodernidad" en: Colombia. El despertar de la modernidad, Fernando Viviescas y Fabio Giraldo (Comp.), Foro Nacional por Colombia, Santa Fe de Bogotá, 1991 págs. 17-31.

Hegel, G. W. F., Lecciones de estética, Volumen 1, Ediciones Península, Barcelona, 1989.

.................. Introducción a la estética, traducción de Ricardo Mazo, Península, Barcelona, 1985 (1971).

, "Prólogo", en: Fenomenología del espiritu, traducción de Wenceslao Roces con la colaboración de Ricardo Guerra, Fondo de Cultura Económica, 1966.

Heidegger, Martin, Interpretaciones sobre la poesía de Hölderlin, Trad. de José María Valverde, Ariel, Barcelona, 1983.

, Approche de Hölderlin, Gallimard, Paris.

Éssais et conférences, Gallimard, Paris, 1958

Caminos del bosque, traducción de A. Leyte y Helena Cortés, Alianza

Universidad, Madrid, 1997.

, Chemins qui ne mènent nulle part, Gallimard, Paris, 1996.

"Ser y tiempo", trad., prólogo y notas de Jorge Eduardo Rivera, Editorial Universitaria, Santiago de Chile, 1998.

México,1951.

El ser y el Tiempo, Traducción José Gaos, Fondo de Cultura Económica, , Etre et temps, Trad. François Vezin, Gallimard, Paris, 1994 (1986).

Conferencias y articulos, Trad. Eustaquio Barjau, Serbal, Barcelona, 1994.

Acheminement vers la parole, Gallimard, Paris,1959.

, De camino al habla, Trad. Yves Zimmermann, Odós, Barcelona, 1987.

Qué es la filosofía, Narcea, Madrid, 1985 (1978).

"La proveniencia del arte y el destino del pensamiento", en Er.

Revista de filosofía, No. 15, 1993, pp. 171-187. 
Holguín, Andrés, Antología crítica de la poesía colombiana, (1874-1974), Tomos I y II, Tercer Mundo, 1981 (1979).

Hume, David, Sobre la norma del gusto, Ediciones Península, Barcelona, 1989, pp. 23-52.

Husserl, Edmund, Meditaciones cartesianas, Trad. Mario Presas, Tecnos, Madrid, 1986.

Iser, Wolfgang, El acto de leer. Teoría del efecto estético, Taurus, Madrid, 1987 (1976).

Jaeger, Werner, Paideia, traducción de Joaquín Xiral y Wenceslao Roces, Fondo de Cultura Económica, México, 2001 (1942).

Jähnig, Dieter, "Arte y realidad", en Historia del mundo: historia del arte, Fondo de Cultura Económica, México, 1982, págs. 9-28.

, "El origen de la obra de arte' y el arte moderno", en: estética. miradas contemporáneas (Editor: Carlos E. Sanabria), Universidad de Bogotá "Jorge Tadeo Lozano, Bogotá, 2004.

Jiménez Panesso, David, Antología de la poesía colombiana, Selección y notas bibliográficas: David Jiménez, Grupo Editorial Norma, Colección Cara y Cruz, Bogotá, 2005, pág. 9 (Este texto contiene por una parte una antología; y por la otra los ensayos "Sobre la presente antología", de David Jiménez, e "Itinerario de las letras colombianas", de Eduardo Camacho Guizado).

Historia de la crítica literaria en Colombia, Universidad Nacional de Colombia-Colcultura, Bogotá, 1992.

"Poesía colombiana: 1980-1989", en: Magazín dominical, El espectador, $\mathrm{N}^{\circ} 348$, diciembre 24 de 1989, págs. 7-9):

"Miguel Antonio Caro: bellas letras y literatura moderna", en: Miguel Antonio Caro y la cultura de su época (Rubén Sierra, editor), Universidad Nacional de Colombia, Sede Bogotá, 2002.

"La poesía de José Manuel Arango", En: José Manuel Arango, La tierra de nadie del sueño. Poemas póstumos, Ediciones DesHora Intergraf, Medellín, 2002, pág. 149.

Kant, Manuel, Crítica del juicio, traducción de Manuel García Morente, Espasa-Calpe, Madrid, 1984 (1977).

Crítica de la facultad de jurgar, traducción de Pablo Oyarzún, Monte Ávila Editores, Caracas, 1992.

Lázaro Carreter, Fernando, De poética y poéticas, Cátedra, Madrid, 1990.

Machado, Antonio, Poesías completas, Espasa Calpe, Buenos Aires, 1994. , Juan de Mairena, dos volúmenes, Losada, Buenos Aires, 1969. Abel Martín, Losada, Buenos Aires, 1990 (1943). 
Manrique, Jorge, Cancionero, Edición, estudio y glosario de Augusto Cortina, Espasa-Calpe, Madrid, 1929, 1941.

Marx, Carlos, "Postfacio a la segunda edición", en: El capital. Crítica de la economía política, Tomo I, Traducción de Wenceslao Roces, Fondo de Cultura Económica, México, 1964.

Merleau-Ponty, Maurice, "El ojo y el espíritu”, en: Eco. Revista de la cultura de Occidente, Nos. 52-54, Tomo IX 4-5-6, agosto-septiembre de 1964, págs. 365-410

Moliner, María, Diccionario de uso del español, dos volúmenes, Gredos, Madrid, 1992.

Mutis, Álvaro, Poesía y prosa, Biblioteca Básica Colombiana, Colcultura, Bogotá, 1981. Obra poética, Arango Editores, Bogotá, 1993. Siete novelas, Alfaguara (Editorial Santillana), Bogotá,1995.

Nietzsche, Friedrich, El nacimiento de la tragedia, traducción de Andrés Sánchez Pascual, Alianza Editorial, Madrid, 2000 (1973).

Paz, Octavio, Cuadrivio. Dario-López Velarde-Pessoa-Cernuda, Seix Barral, Barcelona, 1991 (1965).

Los hijos del limo, Seix Barral, Barcelona, Segunda edición, corregida y ampliada, 1981 (1974).

..............., El arco y la lira, F.C.E, México, 1983 (1956)

.............., Libertad bajo palabra, Fondo de Cultura Económica, México, 1988.

, El Mono Gramático, Seix Barral, Barcelona, 1974.

Pérez Mantilla, Ramón. Textos, editores Lisímaco Parra y Luis Hernando Vargas, Universidad Nacional de Colombia, Bogotá, en prensa editorial.

Platón, República, Editorial Gredos, Madrid, 1985.

Oeuvres complètes, tomes VI-VIII, La république, texte établi et traduit para Emile Chambry avec introduction d' Auguste Diès, Société d'édition "Les belles lettres", Paris, 1947.

El sofista, en: Diálogos V. Parménides, Teeteto, Sofista, Politico, Gredos, Madrid, 1988.

Pöggeler, Otto, El camino del pensar de Martín Heidegger, Alianza Editorial, Madrid, 1983.

Quessep, Giovanni, Antología poética, Instituto Caro y Cuervo, Bogotá, 1983. 2000.

Libro del encantado. Antología, Fondo de Cultura Económica, México,

Real Academia Española, Diccionario de la lengua española, vigésima primera edición, dos volúmenes, Madrid, 1992. 
Robert, Paul, Le Nouveau Petit Robert. Dictionnaire de la langue française, Paris, 1996 (1967).

Russell, Bertrand, Historia de la filosofía occidental, dos volúmenes, Espasa Calpe, Madrid, 1995 (1947).

Ruiz Barrionuevo, Carmen, Summa de Maqroll, el Gaviero. Poesía, 1948-1997. Introducción y edición de Carmen Ruiz Barrionuevo, VI Premio Reina Sofía de Poesía Iberoamericana, Ediciones Universidad de Salamanca, Patrimonio Nacional, 1999 (1997).

Sáez Rueda, Luis, Movimientos filosóficos actuales, Trotta, Madrid, 2003 (2001)

San Agustín, Confesiones, Biblioteca de Autores Cristianos, traducción de José Cosgaya, Madrid, 2004 (1986).

Sánchez Benítez, Roberto, "María Zambrano y la crítica al racionalismo", en Claves de la ražón poética, Revilla, Carmen, Edit., Madrid, Trotta, 1998.

San Juan de la Cruz, Poesías completas, Editorial La Oveja Negra, Bogotá, 1983.

Schaeffer, Jean-Marie, El arte de la edad moderna. La estética y la filosofia del arte desde el siglo XVIII hasta nuestros días, traducción de Sandra Caula, Monte Ávila Editores Latinoamericana, caracas, 1999 (1992).

Seco, Manuel, Diccionario de dudas y dificultades de la lengua española, edición renovada, Espasa Calpe, Madrid, 1986 (también versión en pdf).

Sierra Mejía, Rubén, "La literatura y la filosofía", en: Golpe de dados. Revista de poesía, $\mathrm{N}^{\circ}$ CXXVI, Volumen XXI, Bogotá, noviembre-diciembre de 1993 (Publicado también en el Magazín Dominical, El espectador, enero 16 de 1994, págs. 3-8).

Silva, José Asunción, Poesía y prosa, Biblioteca Básica Colombiana, Colcultura, Bogotá, 1979.

Valéry, Paul, Teoría poética y estética, Visor, Madrid, 1990.

Estudios literarios, trad. Juan C. Díaz, Visor, Madrid, 1985.

Vallejo, César, Obra poética, Edición crítica de Américo Ferrari, Colección Archivos, Editorial Presencia, Bogotá, 1988.

Vallejo, Fernando, Barba Jacob el mensajero. Biografia, Planeta, Bogotá, 1997.

"El gran diálogo del Quijote", en: Babelia, El pais, Madrid, septiembre de 2005.

Vargas Torres, Luis Hernando, Lectura del tiempo en tres poetas latinoamericanos (trabajo de grado para optar al título de "Filósofo"), Departamento de Filosofía, Universidad Nacional de Colombia, Bogotá, 1992 (El trabajo se refiere a poemas humanos, de César Vallejo; "Piedra de sol”, de Octavio Paz; y Cantos de vida y esperanza, los cisnes y otros poemas, de Rubén Darío).

, Memoria de ausente (poesía), Tercer mundo, Bogotá, 1996.

Vattimo, Gianni, Más allá del sujeto, Paidós, Barcelona, 1989. 
, Poesía y ontología, traducción de Antonio Cabrera, Universitat de Valencia, Valencia, 1993.

, "Arte e identidad. Sobre la actualidad de la estética de Nietzsche", en: Diálogo con Nietżsche, Ediciones Paidós, Barcelona, 2001, pp. 159-196.

"Muerte o crepúsculo del arte" (Capítulo III), en El fin de la modernidad: Nibilismo y hermenéutica en la cultura posmoderna, Editorial Gedisa, Barcelona, 1986

Villon, François, Poesía, traducción de Carlos Alvar, Editorial La Oveja Negra, Bogotá, 1983.

Vitier, Cintio, "María Zambrano y Cuba: un testimonio", en: Claves de la razón poética, Revilla, Carmen, Edit., Madrid, Trotta, 1998.

Warren, Austin y Wellek, René, Teoría Literaria, Gredos, Madrid, 1981.

Zambrano, María, El hombre y lo divino, F.C.E., México, 1993 (1955).

, Filosofía y poesía, F.C.E., México, 1996 (1939).

"La reforma del entendimiento", en: Senderos, Anthropos, Barcelona, 1986, págs. 73 a 79 .

"Razón, poesía e historia", en: Pensamiento y poesía en la vida española, Endymion, Madrid, 1987, págs. 15 a 55. 


\section{Índice de nombres}

Aristóteles, 42, 60, 72, 77, 81, 91, 92, 100, 152

Arturo, A., 10, 14, 19, 21, 23, 26, 27, 28, 31, 39, 47, 54, 71, 74, 81, 104, 106, 107, $122,127,128,131,132,137,139,145$, $146,151,156,158,163,168,170,171$, $172,175,181,182,185,186,190,192$, 207, 219, 229, 232

Barba Jacob, 14, 35, 47, 166, 213, 214, 232

Charry L., F., 15, 16, 18, 19, 21, 22, 23, 26, $30,39,40,51,54,56,78,80,81,82$, $111,129,138,148,155,158,161,163$, 166, 167, 168, 172, 178, 184, 185, 233

Cobo B., J. G., 12, 18, 19, 22, 23, 25, 51, 54, 64, 82, 83, 113, 117, 141, 162, 164, 166, 170, 171, 179, 181, 188, 208, 229, 233

Cote L., E., 14, 30, 44, 82, 113, 231

Cruz V., D., 8, 16, 19, 21, 28, 51, 54, 63, $104,109,111,122,127,128,145,154$, 170, 171, 188, 230, 233, 236

De Greiff, L., 14, 35, 37, 82, 113, 139, $160,163,178,182,220$

De Unamuno, M., 17, 38, 44, 55, 60, 61, $86,89,90,92,223$

Echavarría, R., 15, 64, 117, 118, 119, 131, 136, 139, 142, 156, 160, 171, 172, 187, $195,207,234$

Eliot, T. S., 23, 136, 137, 151, 188, 205, 206, 223, 234

González, F., 17, 38, 40, 41, 45, 51, 65, $73,88,90,103,117,134,136,160,171$, 177, 198, 205, 210, 224, 225

Gutiérrez A., C.B., 76, 81, 92, 93, 97, 98, 101, 103, 143

Gutiérrez G., R., 19, 24, 25, 28, 29, 51, 54, 56, 76, 81, 92, 93, 94, 97, 98, 101, 103, 104, 122, 143, 173, 222, 231, 235

Heidegger, M., 9, 10, 17, 23, 26, 42, 44, $49,52,54,60,63,76,77,81,89,91,92$, 93, 94, 95, 96, 97, 98, 99, 100, 101, 102, $103,104,105,106,107,108,111,123$, $126,130,143,149,150,162,179,185$, $188,192,193,225,234,235$

Heráclito, 42, 43, 44, 47, 72, 231

Holguín, A., 15, 21, 26, 29, 30, 236
Jiménez P, D., 2, 6, 16, 17, 18, 19, 23, 24, $26,30,35,47,48,54,56,67,68,75,76$, $77,78,79,80,83,85,109,110,111$, $112,113,119,123,127,128,129,136$, $138,144,146,148,150,155,156,157$, 159, 160, 161, 166, 167, 172, 173, 174, $175,178,182,184,186,189,199,217$, $223,230,236$

López, L. C., 35, 82, 139, 140, 156, 163 , 178, 219

Machado, A., 17, 35, 36, 40, 54, 55, 67, $68,85,86,102,113,114,137,144,159$, $168,176,177,184,185,200,201,203$, 221, 223, 224, 227, 236

Mutis, Á., 10, 14, 18, 21, 22, 23, 26, 27, $30,31,37,54,80,81,82,131,138,139$, $146,161,166,167,172,178,182,185$, 189, 195, 200, 202, 203, 207, 211, 219, 226, 233, 237

Nietzsche, F., 17, 20, 29, 30, 42, 44, 60, 76, 77, 89, 90, 91, 92, 95, 111, 113, 150, $167,192,193,224$

Paz, O., 29, 45, 54, 62, 110, 136, 195, 199 , 237

Pérez M., R., 76, 77, 96, 99, 104, 120, 167, 237

Platón, 25, 42, 69, 81, 86, 91, 92, 93, 94, 100,152

Quessep, G., 14, 18, 19, 39, 40, 66, 72, 82, $86,147,158,163,226,227$

San Juan de la Cruz, 62, 63

Silva, J. A., 16, 17, 18, 20, 21, 22, 23, 26, $28,29,30,34,35,36,37,39,54,56,67$, $68,75,76,77,78,79,81,82,84,86,91$, $103,110,111,112,113,129,131,137$, $138,139,144,145,147,148,150,158$, 159, 163, 164, 165, 167, 169, 170, 171, $173,174,175$,든 $176,177,178,186$, 192, 219, 220, 222, 233, 238

Valéry, P., 10, 53, 54, 59, 66, 83, 93, 94, 116, 141, 144, 148, 161, 199, 238

Vattimo, G., 76, 97, 100, 103, 108, 149, 150, 238

Vidales, L., 156, 178, 181

Zambrano, M., 8, 10, 26, 53, 54, 55, 56, 57, 59, 63, 65, 67, 68, 69, 70, 72, 84, 85, 86, 87, 91, 94, 105, 132, 146, 185, 186, $188,233,238,239$ 